UNIVERSIDADE DE SÃO PAULO

FACULDADE DE ECONOMIA, ADMINISTRAÇÃO E CONTABILIDADE DEPARTAMENTO DE ADMINISTRAÇÃO

SISTEMAS DE AVALIAÇÃO DE DESEMPENHO APLICADOS EM REDES DE FRANQUIAS

Carlos Amorim Lavieri

Orientador: Prof. Dr. Hamilton Luiz Corrêa

SÃO PAULO

2008 
Prof ${ }^{\text {a }}$. Dr ${ }^{\text {a }}$. Suely Vilela

Reitora da Universidade de São Paulo

Prof. Dr. Carlos Roberto Azzoni

Diretor da Faculdade de Economia, Administração e Contabilidade

Prof. Dr. Isak Kruglianskas

Chefe do Departamento de Administração

Prof. Dr. Lindolfo Galvão de Albuquerque

Coordenador do Programa de Pós-Graduação em Administração 


\section{SISTEMAS DE AVALIAÇÃO DE DESEMPENHO APLICADOS EM REDES DE FRANQUIAS}

Dissertação apresentada ao Departamento de Administração da Faculdade de Economia, Administração e Contabilidade da Universidade de São Paulo como requisito para obtenção do título de Mestre em Administração.

Orientador: Prof. Dr. Hamilton Luiz Corrêa

\section{SÃO PAULO}

2008 


\section{FICHA CATALOGRÁFICA}

Elaborada pela Seção de Processamento Técnico do SBD/FEA/USP

Lavieri, Carlos Amorim

Sistemas de avaliação de desempenho aplicados em redes de franquias / Carlos Amorim Lavieri. -- São Paulo, 2008.

$178 \mathrm{p}$.

Dissertação (Mestrado) - Universidade de São Paulo, 2008

Bibliografia.

1. Avaliação de desempenho 2. Franquia 3. Varejo 4. Sistema de franquias I. Universidade de São Paulo. Faculdade de Economia, Administração e Contabilidade II. Título. 
A meus pais, José Armando e Carolina, pelas lições

Às meninas, Ângela Lucas e Helena Amorim, pela inspiração 


\section{Agradecimentos}

Ao Prof. Dr. Hamilton Corrêa, por guiar meus passos acadêmicos, mesmo quando não era sua obrigação. Sua orientação, constante e valiosa, foi essencial para a conclusão deste trabalho; a abertura e amizade encontradas, gratas surpresas.

Ao Prof. Dr. Antonio César Amaru Maximiano, por me acolher na FEA USP, e saber como me auxiliar nos diferentes momentos vividos nesse processo. Ao Prof. Dr. Silvio Aparecido dos Santos, pela sua atuação, participação e crítica.

Ao pesquisador Marcus Rizzo, por todos os conselhos e esclarecimentos, inclusive práticos, em relação às franquias.

Aos professores da FEA USP que tornaram possível este trabalho. Aos funcionários da USP. À comunidade do Estado de São Paulo, por manter essa Universidade e suas oportunidades.

Aos diversos colegas, Anne, Bia, Daniela, Camila, Claudinei, Daniel, Patrícia G., mestrandos e doutorandos, pelas dicas e camaradagem, e ao Flavio Hourneaux Jr, pela paciência. Também agradeço em especial àqueles que contribuíram diretamente com o

trabalho: Reni Berezin (estatística), Angélica Durante (traduções) e Érica de Freitas (revisão).

Às diversas pessoas e organizações, ligadas ao universo das franquias, que me abriram portas ou me receberam, como Luiz Sakuda, Pedro Mello, Cristina Franco, Raquel Queiroz, Filomena Garcia, João Vianna, Patrícia Vance, entre tantos outros.

Aos amigos, pela paciência, e ao time, Roberta, Michele, Mariah, Willy, Viviane, Raquel, pela força.

À Ângela, pela parceria.

Aos meus pais e irmãos, por tudo. Aos meus avós, por serem belos exemplos, por conhecerem e compartilharem seus caminhos. 
“Contra o positivismo, que pára perante os fenômenos e diz: 'Há apenas fatos', eu digo: 'Ao contrário, fatos é o que não há; há apenas interpretações. " Nietzsche 


\section{RESUMO}

Este trabalho consiste em um estudo realizado com franqueadores e masterfranqueados, e foca o sistema de avaliação aplicado em unidades franqueadas no Brasil. Por meio de um questionário auto-administrado, 63 franqueadores forneceram informações sobre o processo de avaliação realizado. Descreveram-se e se consideraram os sistemas de avaliação dos franqueadores em relação aos modelos teóricos. Encontraram-se evidências de a complexidade do processo de avaliação relacionar-se à definição de objetivos para os franqueados e de seu acompanhamento pelos franqueadores. Além disso, a análise dos dados revelou que não há clareza para uma parcela dos franqueadores sobre como realizar as avaliações, dentro de um processo de parceria. Além disso, verificaram-se os aspectos que mais facilitam e mais dificultam essas avaliações, bem como a influência de características como o tamanho da rede, a forma de remuneração do franqueador (royalty ou taxa fixa) e a idade da rede, no sistema de avaliação.

Palavras-Chave: 1. Avaliação de desempenho 2. Franquia 3. Varejo 4. Sistema de franquias 


\begin{abstract}
This study was conducted with franchisors and master-franchisees focusing performance measurement system applied at franchisee units. Through a survey research, 63 franchisors provided information about the evaluation process carried out. The franchisors performance measurement systems were described and considered in comparison to theoretical models. Data analysis indicates that evaluation process complexity is associated with franchisees objectives definition and its development following by the franchisors. Besides this, the results suggest that the evaluation process in a partnership relation is not clear for some of the franchisors. This research has determined the aspects which make the evaluation easier or more difficult, as well as the influence of size, remuneration form, and age in this process.
\end{abstract}

Key-Words: 1. Performance Measurement 2. Franchise 3. Retail 4. Franchising 


\section{SUMÁRIO}

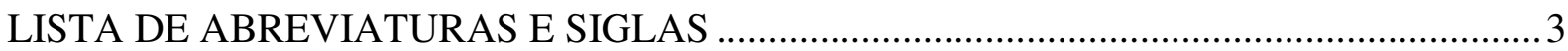

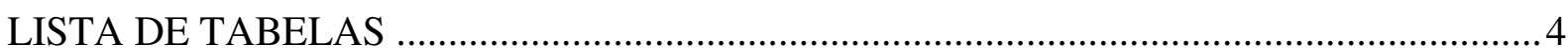

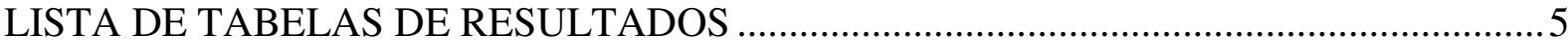

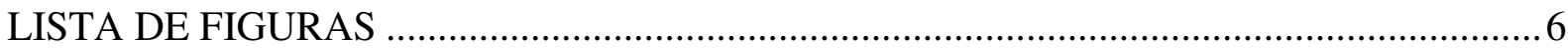

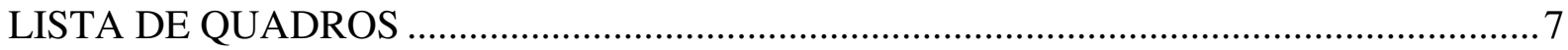

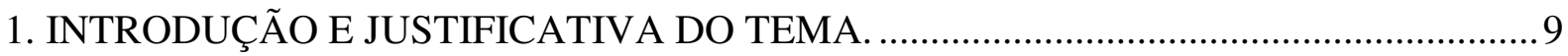

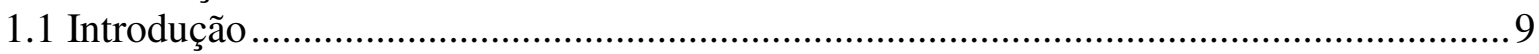

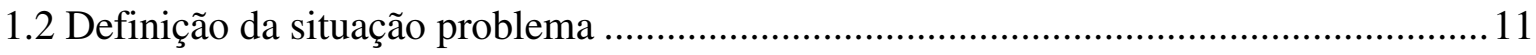

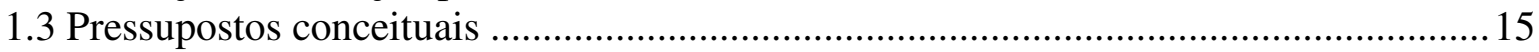

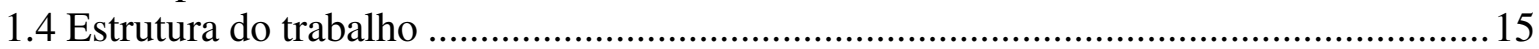

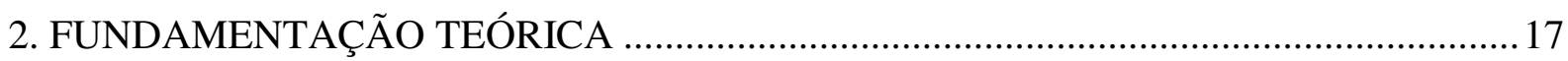

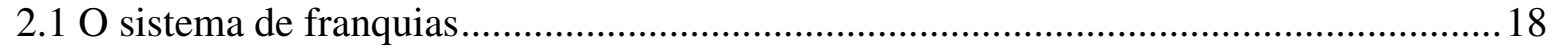

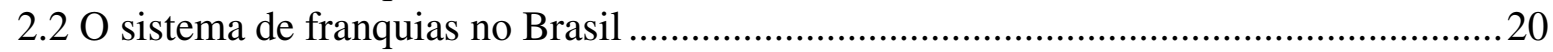

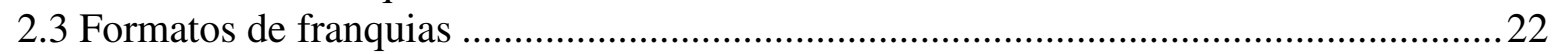

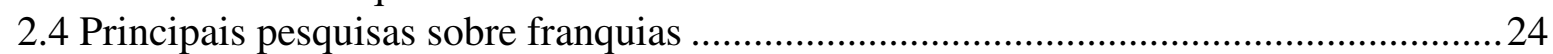

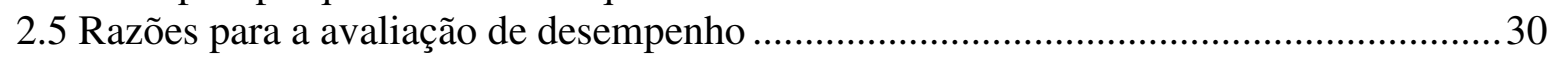

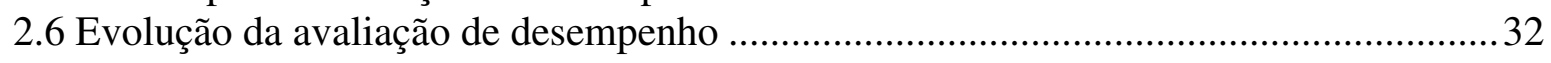

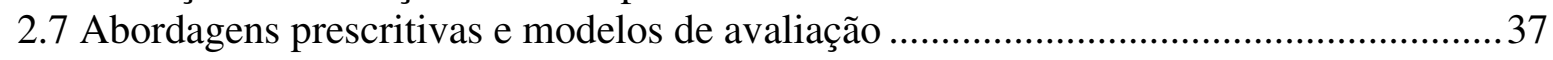

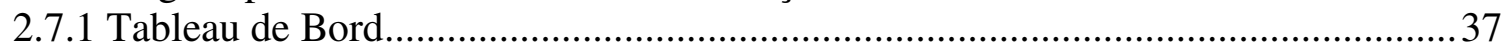

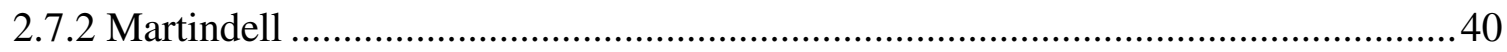

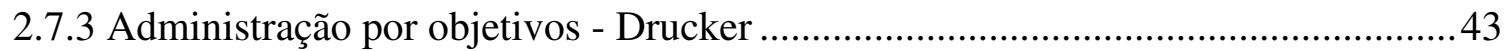

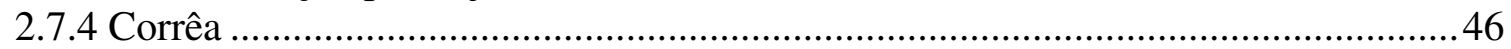

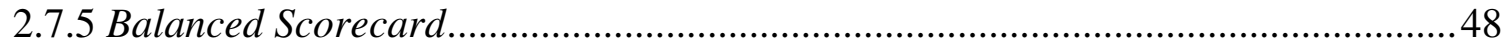

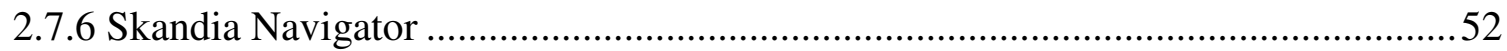

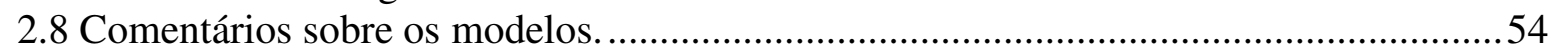

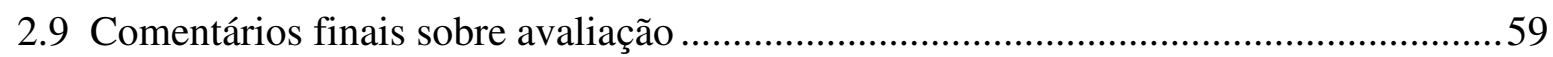

2.10 A avaliação de desempenho em franquias........................................................62

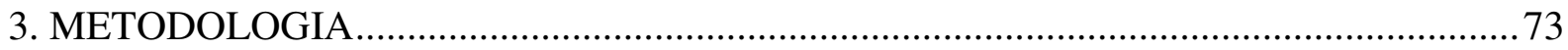

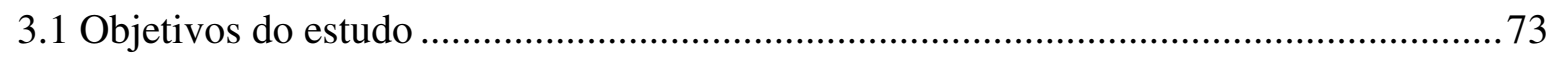

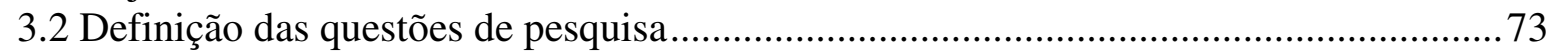

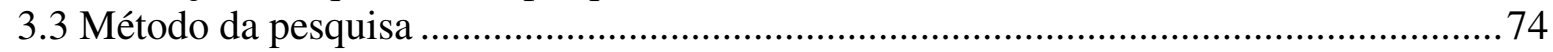

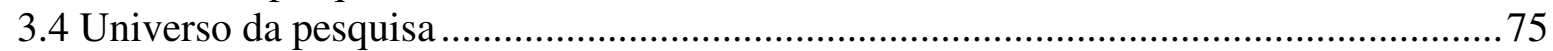

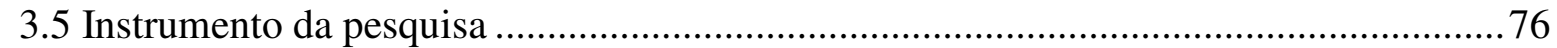

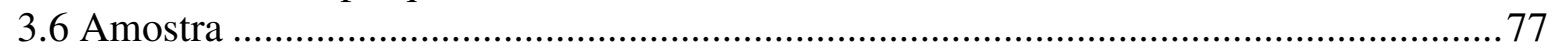

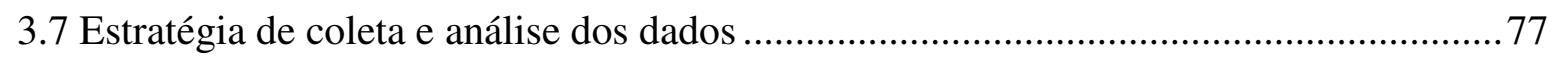

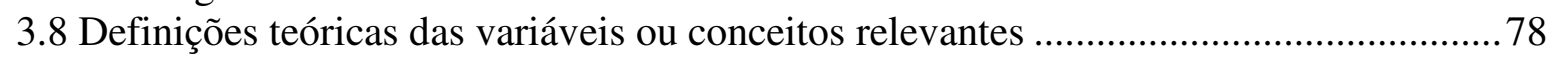

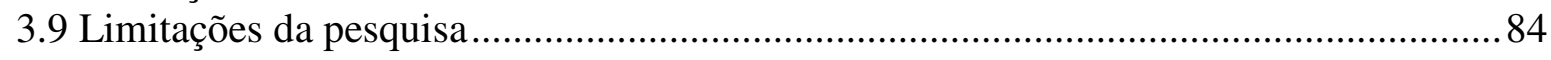

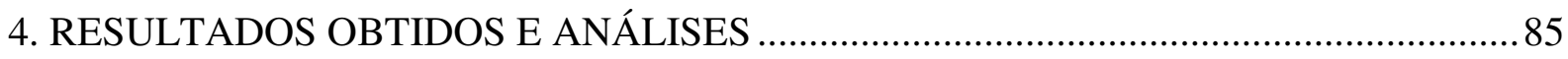

4.1 Resultado da pesquisa - caracterização dos respondentes ......................................... 85 
4.2 Avaliação em franquias - freqüências obtidas ......................................................... 88

4.3 Observações sobre os resultados relativos a freqüência de respostas. ..........................98

4.4 Resultados obtidos e observações com relação aos setores de atuação......................... 103

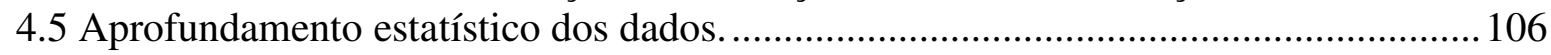

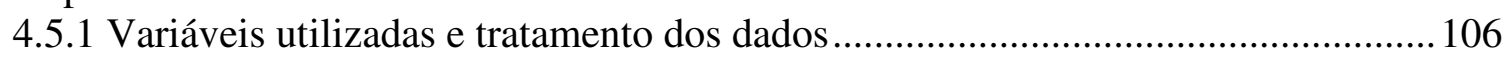

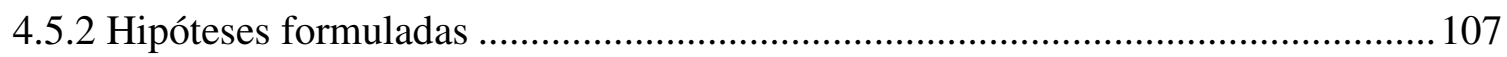

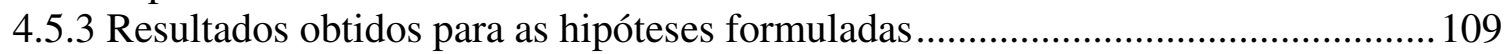

4.5.4 Estudo de dependência entre os índices ............................................................... 137

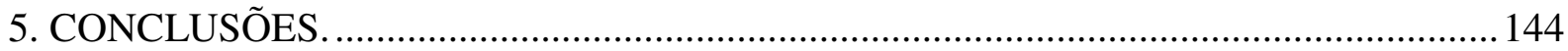

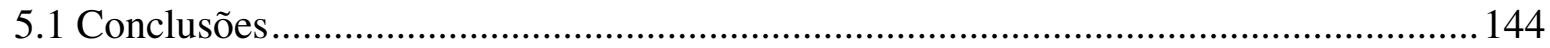

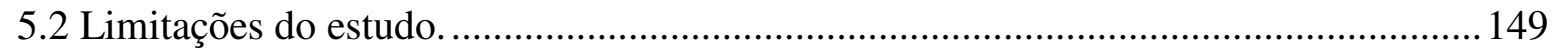

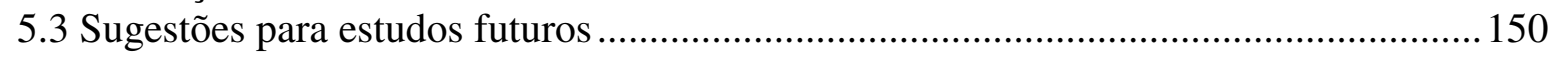

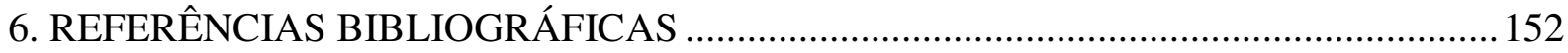

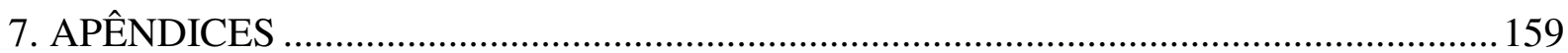

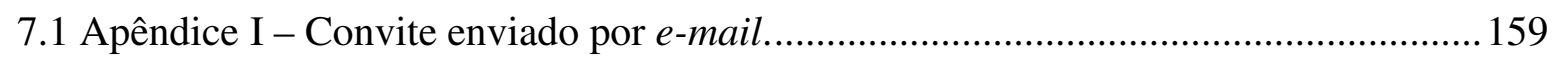

7.2 Apêndice II - Instrumento de coleta de dados ............................................................. 160

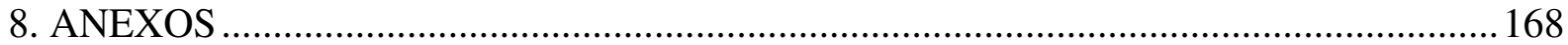

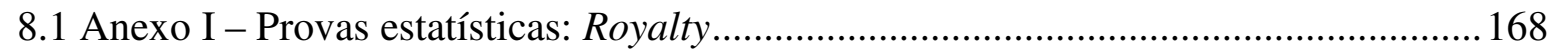

8.1 Anexo II - Provas estatísticas: Definição de objetivos e acompanhamento ................. 170

8.1 Anexo III - Provas estatísticas: Tamanho da rede ........................................................ 172

8.1 Anexo III - Provas estatísticas: Tamanho da rede ....................................................... 172 


\section{LISTA DE ABREVIATURAS E SIGLAS}

ABF: Associação Brasileira de Franchise APO: Administração Por Objetivos

BSC: Balanced Scorecard

IFA: International Franchising Association TBD: Tableau de Bord 


\section{LISTA DE TABELAS}

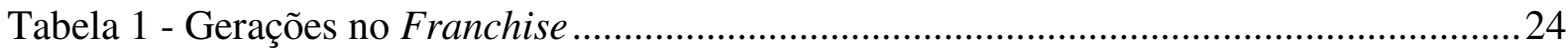

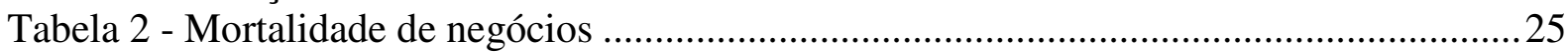

Tabela 3 - Pontuação segundo Martindell .............................................................................. 41

Tabela 4 - Evidências de fatores não racionais no processo decisório...................................56

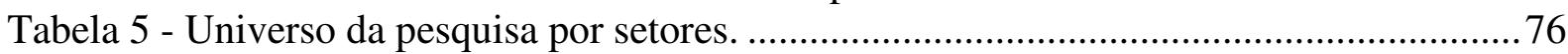

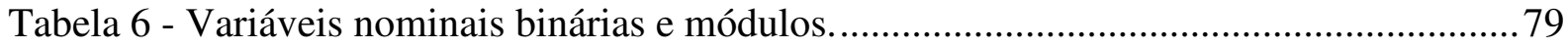

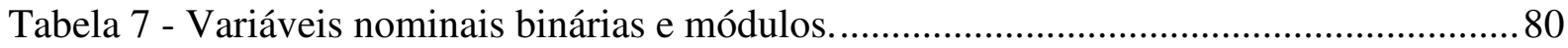

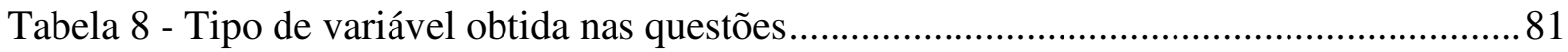

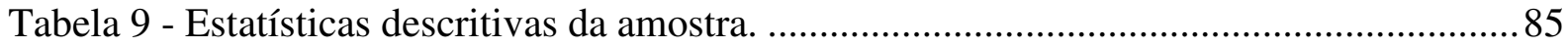

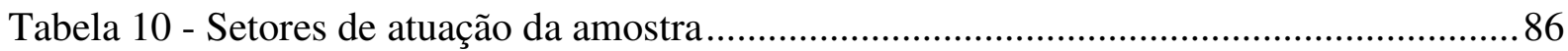

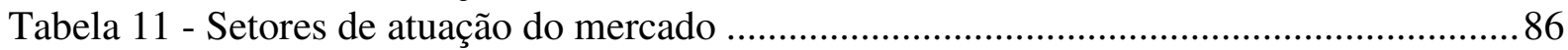

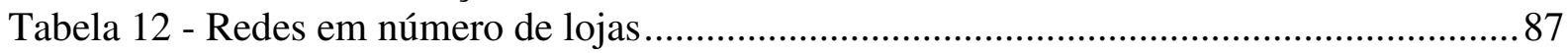

Tabela 13 - Etapas existentes no processo de avaliação das franquias da amostra.................. 88

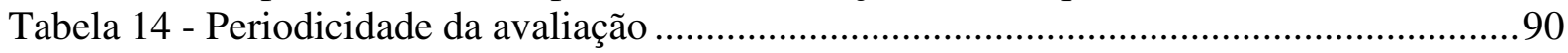

Tabela 15 - Avaliação das dimensões financeira e vendas................................................... 90

Tabela 16 - Dimensões avaliadas (manutenção, marca, clientes, equipe) ................................92

Tabela 17 - Dimensões avaliadas (logística, parcerias, inovação) ........................................93

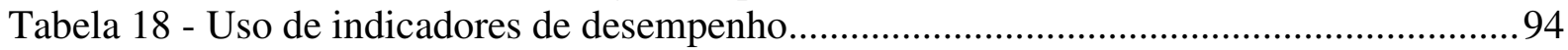

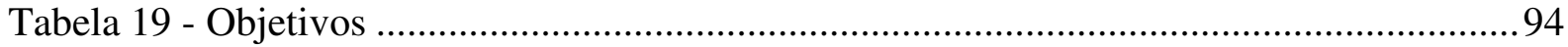

Tabela 20 - Participação do franqueado na definição dos objetivos e metas. ......................... 95

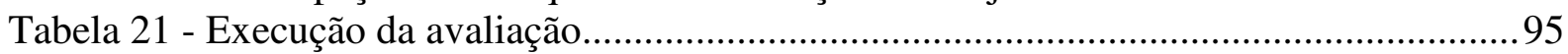

Tabela 22 - Envio do resultado da avaliação para o franqueado .............................................96

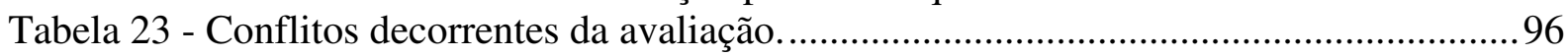

Tabela 24 - Escala de respostas para os itens e peso considerado.........................................97

Tabela 25 - Aspectos que facilitam ou atrapalham a avaliação............................................97

Tabela 26 - Avaliação dos módulos (Financeiro e venda) por setor ........................................ 103

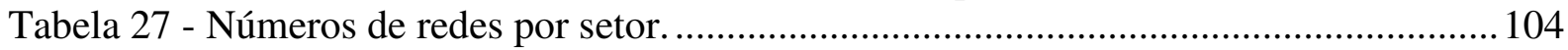

Tabela 28 - Segmentação do setor de ensino e educação ...................................................... 105

Tabela 29 - Freqüência de acompanhamento dos itens propostos, por setores de atuação.... 105

Tabela 30 - Resultados das hipóteses de 1 até 4 .................................................................. 148

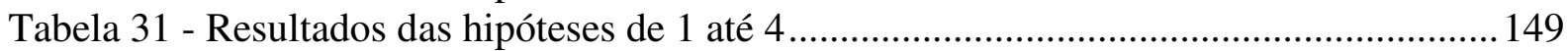

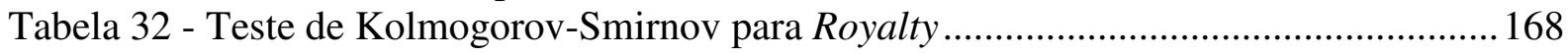

Tabela 33 - Freqüências Mann-Whitney para Royalty ...................................................... 168

Tabela 34 - Provas estatísticas para Royalty .................................................................... 169

Tabela 35 - Comparação entre Royalty X remuneração por Taxa fixa ................................. 169

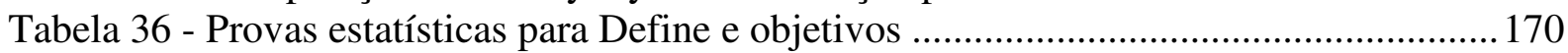

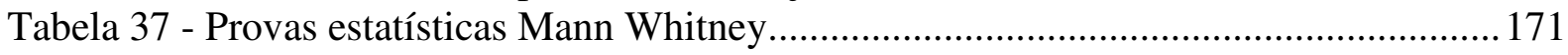

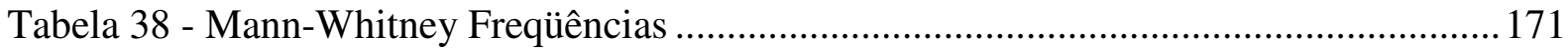

Tabela 39 - Kolmogorov-Smirnov para Define objetivos .................................................. 171

Tabela 40 - Prova estatística para Tamanho da rede. ......................................................... 172

Tabela 41 - Comparação entre grandes e pequenas franquias ............................................... 172 


\section{LISTA DE TABELAS DE RESULTADOS}

Tabela de resultado 1 - Hipótese 1

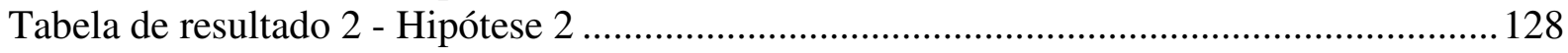

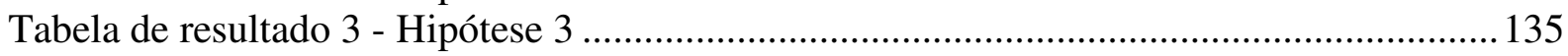

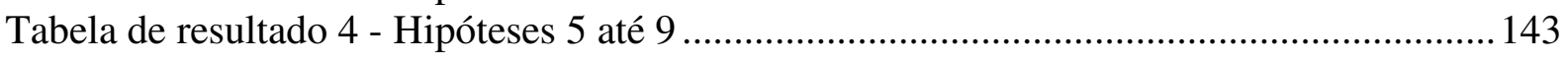




\section{LISTA DE FIGURAS}

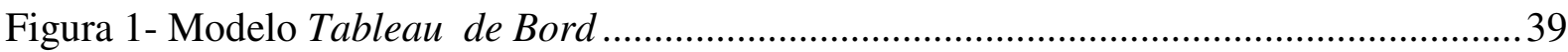

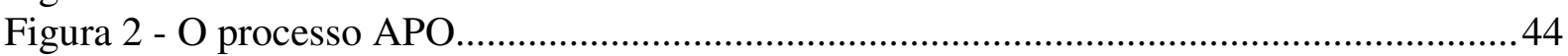

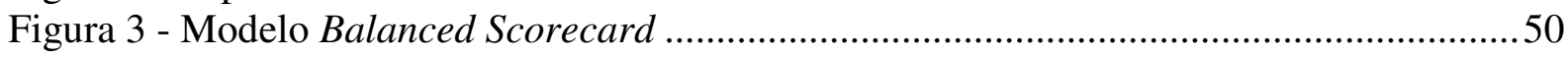

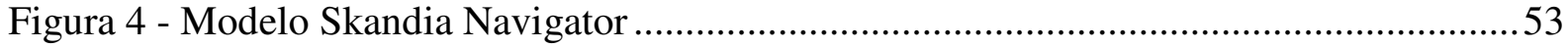




\section{LISTA DE QUADROS}

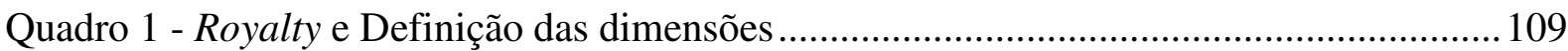

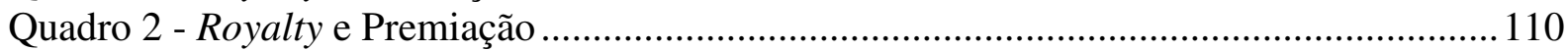

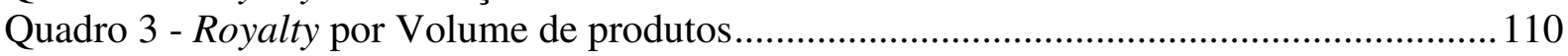

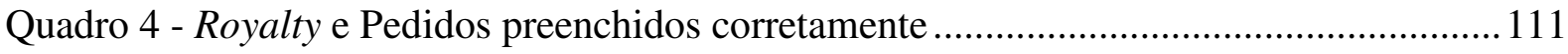

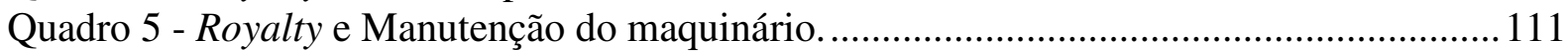

Quadro 6 - Royalty e Verificação dos objetivos alcançados ................................................ 112

Quadro 7 - Royalty e Quantidade de objetivos definidos .................................................... 112

Quadro 8 - Define e acompanha objetivos por Definição da equipe....................................116

Quadro 9 - Define e acompanha objetivos por Definição dos módulos .................................116

Quadro 10 - Define e acompanha objetivos por Definição de pesos......................................116

Quadro 11 - Define e acompanha objetivos por Construção de indicadores..........................116

Quadro 12 - Define e acompanha objetivos por Integração nos módulos..............................116

Quadro 13 - Define e acompanha objetivos por Sugestão de mudanças ................................116

Quadro 14 - Define e acompanha objetivos por Revê a avaliação......................................... 117

Quadro 15 - Define e acompanha objetivos por Monitora lucro ........................................... 118

Quadro 16 - Define e acompanha objetivos por Outros aspectos financeiros......................... 118

Quadro 17 - Define e acompanha objetivos por Avaliação financeira.................................118

Quadro 18 - Define e acompanha objetivos por Manutenção ............................................119

Quadro 19 - Define e acompanha objetivos por Espaço físico ...........................................119

Quadro 20 - Define e acompanha objetivos por Atualização .................................................119

Quadro 21 - Define e acompanha objetivos por Consumo energia ......................................120

Quadro 22 - Define e acompanha objetivos por Higiene na loja ...................................... 120

Quadro 23 - Define e acompanha objetivos por Índice de operação..................................... 120

Quadro 24 - Define e acompanha objetivos por Fachada...................................................... 121

Quadro 25 - Define e acompanha objetivos por Índice imagem da marca............................ 121

Quadro 26 - Define e acompanha objetivos por Mudanças na concorrência ......................... 122

Quadro 27 - Define e acompanha objetivos por Fidelização. ................................................. 122

Quadro 28 - Define e acompanha objetivos por Perfil do cliente ........................................ 122

Quadro 29 - Define e acompanha objetivos por Atendimento ............................................... 122

Quadro 30 - Define e acompanha objetivos por Índice da dimensão cliente .........................123

Quadro 31 - Define e acompanha objetivos por Eficiência dos funcionários ......................... 123

Quadro 32 - Define e acompanha objetivos por Treinamento do franqueado........................ 123

Quadro 33 - Define e acompanha objetivos por Treinamento equipe .................................... 124

Quadro 34 - Define e acompanha objetivos por Atendimento da equipe............................. 124

Quadro 35 - Define e acompanha objetivos por Identificação com a marca.......................... 124

Quadro 36 - Define e acompanha objetivos por Índice relativo a equipe ............................. 124

Quadro 37 - Define e acompanha objetivos por Dimensão relativa a logística ..................... 125

Quadro 38 - Define e acompanha objetivos por Participação em ações da rede.....................125

Quadro 39 - Define e acompanha objetivos por Índice relativo a parcerias............................126

Quadro 40 - Define e acompanha objetivos por Inovações do franqueador ..........................126

Quadro 41 - Define e acompanha objetivos por Inovações do franqueado............................126

Quadro 42 - Define e acompanha objetivos por Sugestões de mudanças ...............................127

Quadro 43 - Define e acompanha objetivos por Dimensão inovação ..................................... 127

Quadro 44 - Tamanho da rede por Etapa definição da equipe. .............................................. 130

Quadro 45 - Tamanho da rede por Etapa definição dos módulos ..........................................130

Quadro 46 - Tamanho da rede por Etapa definição dos pesos dos itens ...............................130

Quadro 47 - Tamanho da rede franqueada por Manutenção do equipamento.........................131

Quadro 48 - Tamanho da rede franqueada por Condições do espaço físico .......................... 131

Quadro 49 - Tamanho da rede franqueada por Higiene na loja............................................ 131 
Quadro 50 - Tamanho da rede franqueada por Condições da fachada ................................. 132

Quadro 51 - Tamanho da rede franqueada por Eficiência equipe .........................................132

Quadro 52 - Tamanho da rede e participação em Ações sociais .........................................133

Quadro 53 - Tamanho da rede e Participação nos grupos de franqueados .............................133

Quadro 54 - Tamanho da rede e Tempo de existência .......................................................... 134

Quadro 55 - Tempo de existência e Verificação judicial ..................................................... 136

Quadro 56 - Tempo de existência e Número de lojas............................................................ 136

Quadro 57 - Relação entre Tipo de remuneração e Tamanho da rede. .................................139

Quadro 58 - Tipo de remuneração e Definição e acompanhamento de objetivos..................139

Quadro 59 - Define e acompanha objetivos por Tamanho da rede..................................... 140

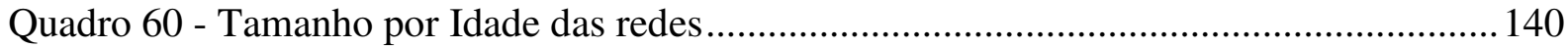

Quadro 61 - Idade da rede por Define e acompanha objetivos .......................................... 141

Quadro 62 - Independência entre crescimento e Avaliação estruturada ................................. 142 


\section{INTRODUÇÃO E JUSTIFICATIVA DO TEMA.}

\subsection{Introducão}

As pessoas, em geral, procuram soluções que possam melhorar as condições da vida humana em sociedade, a qual ocorre freqüentemente associada às organizações. Normalmente, os indivíduos nascem em hospitais, frequientam escolas e trabalham em empresas. As organizações executam a maioria das atividades das sociedades modernas e o caminho para o entendimento do homem moderno conduz, portanto, ao estudo das organizações complexas. (LAMCOMBE; HEILBORN, 2003, p.13).

As franquias, relativamente recentes no universo das organizações, se comparadas a outros modelos, como as empresas de capital privado, o Estado, ou mesmo as empresas de capital aberto, já são uma realidade mundial. De acordo com a International Franchise Association (2005), nos Estados Unidos da América havia 910.000 estabelecimentos em 2004 operando por meio do sistema de franquias. Na Austrália, havia 54.000 lojas em 2004 (MERRILEES; FRAZER, 2006, p.1), enquanto no Brasil listam-se, aproximadamente, 94.000 unidades, creditam-se 991.000 empregos diretos ao setor, e um faturamento correspondente a 9,71\% do Produto Interno Bruto (RIZZO, 2006, p.13).

Estima-se a rede mundial de franquias em mais de 1.800 .000 unidades, em mais de 60 países (Ibid, p.16). O sistema de franquias mostra-se, portanto, uma alternativa viável para o desenvolvimento econômico, inclusive nos antigos países comunistas (CRETELLA, 2003, p.29). Além disso, é uma interessante solução para distribuição de produtos e/ou serviços pelas organizações. Sua importância crescente na economia mundial explica o interesse da academia pelo assunto e por estudos que possibilitem mais compreensão sobre essa forma de organização.

Ao desejo de conhecimento sobre as franquias acrescenta-se o interesse crescente nos últimos anos pela avaliação e mensuração do desempenho organizacional. As ciências, de modo geral, desde o desenvolvimento do método cientifico, têm a preocupação da medição. No entanto, como aponta Maximiano (2002, p.75), em 3100 a.C. no Egito já havia a preocupação em quantificar em dias a regularidade das cheias do Nilo. Como perceberam os egípcios, a medição possibilita inferências e a construção de modelos que nos permitem atuar no mundo 
com maior segurança. A idéia de analise e medição, ligadas ao conceito de eficiência, aparecem posteriormente na obra de James Mill, no início do século XIX (MAXIMIANO, 2005, p.46). Também a Fundição Soho, no início do século XIX, já aplicava práticas que se tornariam universais nos séculos seguintes: a cronometragem e estudo dos tempos e movimentos; o pagamento de incentivos proporcionais à produtividade; e o planejamento e controle da produção, baseados em estimativas de procuras por máquinas. (ibid, p.46). A chamada administração científica buscava a eficiência da produção, e, nesse sentido, avaliar os resultados sejam produtivos ou financeiros, era essencial. Essas são algumas das origens da avaliação de desempenho.

Nos últimos anos, o interesse pela avaliação de desempenho aumentou e atingiu áreas e organizações que antes não viam esse tópico como prioritário (BEHN, 2003). Sistemas de avaliação de desempenho global, que consideram a estratégia empresarial na construção dos indicadores, como o Balanced Score Card (Balanced Scorecard), ganharam notoriedade e hoje estão presentes em grandes empresas. Kaplan e Norton (2001, p.21) citam algumas organizações nas quais a utilização do Balanced Scorecard teria sido responsável pelo alinhamento estratégico da organização, e por relevantes resultados: AT\&T Canadá, Zeneca Ag Products North América, Southern Gardens Citrus, University of Califórnia, entre outras.

Relaciona-se com esse crescente interesse pelos indicadores e pela avaliação a ênfase proposta pela gestão estratégica, mesmo que não explicitamente, ao encadeamento entre as atividades realizadas e seu alinhamento com a estratégia da empresa. Considerando estratégia como o ajuste entre as atividades de uma empresa, a capacidade de fazer bem várias coisas, e a integração entre estas, fica claro que se não há ajuste entre as atividades, não há estratégia diferenciada e a sustentabilidade fragiliza-se (MINTZBERG et. al. 2006, p.39). Alguns autores consideram o alinhamento entre estratégia e atividades, e mais significativamente ainda, um resultado efetivo nas organizações, conseqüência direta de um bem construído sistema de avaliação de desempenho global (KAPLAN; NORTON, 2001, p.9).

Hourneaux Jr. (2005, p.143), sugere que pesquisas em diferentes setores econômicos evidenciaram diferenças intrínsecas na concepção dos sistemas de avaliação de desempenho.

Considerando esses dois aspectos, ou seja, o interesse que se tem atribuído ao sistema de franquias como modelo de negócio, e também a relevância para a administração das 
organizações da avaliação de desempenho global, e tendo em mente também que não se encontraram outros estudos sobre franquias que tenham os modelos de avaliação como tema principal, no presente estudo pressupõe-se que há aspectos únicos nos sistemas de avaliação de desempenho elaborados para o franchising, bem como em suas ferramentas de controle estratégico, e aprofunda-se no assunto em busca de maior conhecimento sobre o tema.

\subsection{Definição da situação problema}

O processo de integração dos diversos mercados e o avanço tecnológico que marcaram o século XX aparentam, no novo século, continuar em franco desenvolvimento. O aumento do fluxo de capitais entre países, do comércio mundial e também a maior integração das organizações são tendências sensíveis a qualquer observador. Esse quadro é marcado também pela necessidade de novas formas de ação para nações, empresas e pessoas. A facilidade de acesso a produtos, idéias e serviços, por um lado cria o consumidor mundial e permite uma participação do indivíduo de forma impar na história da humanidade, por outro também exclui parte da humanidade dos mercados e impõe uma separação econômica ainda maior entre as pessoas (HARVEY, 1996). Percebe-se esse cenário de transformação dos tempos de produção e consumo simultaneamente como fonte de inquietação e oportunidade.

A fim de sobreviver nesse cenário, diferentes estratégias têm sido consideradas pelas organizações. Aplicam-se distintos modelos de negócios, e também se submetem freqüentemente ferramentas de gestão novas ou já consolidadas ao teste prático (MAXIMIANO, 2002, p.483). Soma-se a esse cenário a evolução da informática, do uso dos computadores e dos softwares, que permitiu aumentar radicalmente a quantidade de dados disponíveis aos gestores, mas não necessariamente a utilidade das informações, e também o crescimento da complexidade das organizações em si, e ficará fácil compreender por que o assunto avaliação de desempenho organizacional tornou-se recorrente nas recentes pesquisas de administração e na prática das organizações. De acordo com a edição londrina do Financial Times, já em 1997, 60\% das empresas nos Estados Unidos utilizavam sistemas de avaliação de desempenho que agregavam indicadores financeiros e não-financeiros (FINANCIAL TIMES, apud. AMPUERO et al., 1998). 
Ademais, já em 1954, a administração por objetivos apontara a importância da avaliação para os administradores, do estabelecimento de objetivos e de determinar o que avaliar, e qual o padrão de medida a ser usado, pois "os elementos incluídos nas medidas tornam-se relevantes, os omitidos, desaparecem" (DRUCKER, 1981, p.61). No entanto, a prática revela alguns problemas:

De acordo com uma pesquisa da KPMG realizada com 143 alto-executivos da área privada ou pública, $93 \%$ deles acreditam que a mensuração é muito eficiente, ou de alguma maneira eficiente, em influenciar o desempenho de suas áreas, mas apenas $51 \%$ estão comparativamente satisfeitos com os seus atuais sistemas de avaliação. ${ }^{1}$ (DRICKHAMER, 2002, p.14)

Existem diversos sistemas de mensuração, e a escolha entre eles não é tarefa simples. De acordo com Ampuero et al. (1998, p.45), "rumores sobre a simplicidade da mensuração são exagerados, o que explica a profusão de novos conceitos nesta área. Nos dias de hoje, parece que qualquer um tem uma nova ferramenta de mensuração." ${ }^{2}$.

O modelo Balanced Scorecard, atualmente um dos mais utilizados, é lembrado também por ter sublinhado a importância dos sistemas de avaliação também para o gerenciamento estratégico e não como simples índices numéricos construídos à revelia da estratégia. Existem sistemas de avaliação baseados em índices numéricos operacionais ou financeiros que apenas informam um valor, sem considerar a conexão destes com a estratégia (FRANCO-SANTOS, 2007, p.798).

Entretanto, sistemas que consideram a estratégia em sua concepção, também são alvos de críticas, como as de Voepel et al. (2006 p.49) sobre os conflitos entre o modelo citado, a inovação e a flexibilidade exigida na nova economia: "quando aplicado na economia da inovação, o Balanced Scorecard mostra limitações significativas em lidar com as rápidas mudanças do ambiente de redes coorporativo" ${ }^{3}$. Mesmo seus principais defensores fazem ressalvas quanto à sua utilização descuidada: "o scorecard deve representar o pensamento e as energias da equipe executiva da unidade de negócios. A menos que essa equipe esteja

\footnotetext{
${ }^{1}$ No original: According to a KPMG survey of 143 upper executives from industry and government, $93 \%$ of leaders believe measurement is very or somewhat effective in influencing performance in their areas, but only $51 \%$ are comparatively satisfied with their current measurement systems.

${ }^{2}$ No original: Rumors of the simplicity of measurement are grossly exaggerated, which may explain the profusion of powerful new concepts in this area. These days, it seems that everyone has a new measurement tool. ${ }^{3}$ No original: When applied in the innovation economy, the BSC displays significant limitations in dealing with the new, rapidly changing and networked corporate environment.
} 
totalmente engajada no processo, é improvável um resultado bem-sucedido" (KAPLAN; NORTON 1997, p.307).

De qualquer forma, os sistemas de avaliação de desempenho são atualmente uma prática comum às organizações em geral e não somente às empresas. Por exemplo, a Sociedade de Estatística Real Inglesa, em trabalho escrito por Bird (2005), mostra que os serviços públicos do Reino Unido intensificaram nos anos noventa o monitoramento da performance dos serviços, em busca de melhorias de eficiência e eficácia, processo que continua até hoje. Compreender esses sistemas, a razão de seu sucesso como ferramenta de gestão, e as especificidades de seu uso nos diversos casos ligados à administração das organizações permitirá aos gestores um desempenho mais eficiente, o que, por si, já justifica estudos sobre o tema.

Entretanto, conforme já citado, os modelos de negócios também apresentam especificidades cada vez maiores, e distintas soluções para a sobrevivência no mercado. Nesse contexto, o sistema de franquias tem obtido resultados significativos, não tendo apenas sobrevivido, mas também se expandido consideravelmente. Segundo Welsh et al. (2006) as vendas através dos sistemas de franquias cresceram 94\% entre 1983 e 1993 nos Estados Unidos. Evidenciando a importância das franquias, já havia na China, em abril de 2001, mais de 320 lojas da cadeia Mc Donald's. Os autores também apontam que em países emergentes, como Índia, China, México, Rússia e Brasil, mesmo em mercados maduros como o de fast food ainda há espaço para crescimento de franquias. O sistema destaca-se com relação ao empreendedorismo, pois permite aos novos empreendedores operarem com marcas reconhecidas pelas suas qualidades em um mercado que demanda qualidade (WELSH et al. 2006, p.144).

O sistema de franquias realiza-se através de uma relação entre duas ou mais organizações. $\mathrm{O}$ sistema consiste na essência em replicar em diversos locais ou mercados um mesmo conceito de negócio (CHERTO, 2006, p.21). Segundo o autor, cada uma das réplicas é implantada, gerida e operada por um terceiro autônomo, o franqueado, a quem a franqueadora, mediante contrato, autoriza a comercialização de determinados produtos e/ou prestação de serviços, em combinação com o uso de marca(s), métodos, padrões, sistemas e políticas, desenvolvidos e/ou estipulados pela franqueadora. 
O sistema de franquias compõe, portanto, uma relação entre organizações, o que explica o interesse de diversos pesquisadores que o consideraram uma situação favorável para estudar teorias como as de agência e da firma. Pesquisadores como Lafonteine (1992), Silva (1999), Frazer e Waven (2007), Spinelli e Birley (1998), Combs e Ketchen (2003), entre outros, defendem que o franchising oferece uma rara oportunidade para avaliar as teorias concernentes as decisões de contratos entre firmas. Essa oportunidade ocorre porque, primeiramente, os franqueadores muitas vezes franqueiam apenas parte de suas das lojas, já que mantém também lojas próprias; assim, a propensão da organização a franquear pode ser utilizada como variável, considerando a porcentagem de lojas franqueadas em comparação ao total de lojas próprias. Em segundo, porque os contratos de franquia envolvem pagamento de royalty sobre porcentagem do faturamento (situação de maior risco para o franqueador), e de taxas fixas (situação de menor risco para o franqueador), o que permite avaliar e inferir sobre as condições em que os contratos são elaborados e os franqueados escolhidos ou refutados (LAFONTEINE, op. cit.).

Aqui cabe lembrar que parte das questões e das teorias apresentadas sobre o sistema de franquias foca o comportamento do franqueado e do franqueador, e da maneira como problemas de risco moral podem ocorrer, através do conflito de interesses entre eles (Combs e Ketchen, 2003). Em todas essas questões, o monitoramento do comportamento do franqueado, e também do franqueador, é essencial. Acrescenta-se que a comunicação da estratégia pelo franqueador aos franqueados é um dos fatores críticos ao desempenho da rede, conforme observa Cherto (2006, p.409):

\begin{abstract}
Afinal, toda organização de franchising constitui uma cadeia de valor e qualquer ganho de eficiência que se possa obter através da melhor integração dos componentes dessa cadeia, ou da apropriação, análise e compreensão das inúmeras informações que a rede tem condições de captar, pode fazer uma diferença enorme no processo de tomada de decisão e nos resultados de todos os envolvidos.
\end{abstract}

Para completar a situação até aqui apresentada, recorda-se que os sistemas de avaliação de desempenho podem apresentar quatro funções principais: a comunicação da estratégia, o monitoramento da(s) organização (ões), possibilitar a busca das causas do desempenho destas e permitir a reavaliação dos objetivos. Sabe-se também que comunicar rapidamente as mudanças estratégicas, assegurar-se que os franqueados compreendam estas mudanças, e conhecer o desempenho real da organização, e de seus parceiros, bem como suas causas são 
fatores importantes para o sucesso do sistema de franquias. Considerando ainda que as especificidades do sistema de franquias, como os potenciais conflitos de interesse entre franqueador e franqueado, bem como de necessidade de ajustes rápidos da rede de franqueados para absorver alterações de mercado entre outras, apresentam-se como um caso de interesse especial para pesquisas sobre avaliação de desempenho global. Assim, o presente trabalho propõe considerar as especificidades da avaliação de desempenho global em sistemas de franquias. Apresenta-se, dessa forma, o objetivo geral do trabalho:

Identificar e descrever a utilização dos sistemas de avaliação de desempenho e suas características em organizações que operam por meio das redes de franquias.

\subsection{Pressupostos conceituais}

Assume-se como um pressuposto conceitual deste estudo que existem esforços por parte das sociedades nacionais e das organizações a fim de aumentar a competitividade de seus integrantes, evidenciados por órgãos de fomento à criação de empresas, de desenvolvimento tecnológico e linhas de incentivo à atividade econômica.

Além disso, o presente estudo parte da premissa que o sistema de franquias funciona como uma parceria entre organizações, e pode ser avaliado através de indicadores, bem como gerenciado pelos parceiros (franqueador e franqueado), ou somente pelo franqueador.

\subsection{Estrutura do trabalho}

Divide-se este trabalho em cinco partes. O primeiro capítulo, já apresentado, situa o estudo e apresenta uma revisão geral do assunto, enfocando e justificando o problema de pesquisa, os pressupostos conceituais e as limitações do estudo.

O segundo capítulo apresenta a fundamentação teórica, na qual relacionam-se os principais conceitos pertinentes ao sistema de franquias, um breve histórico, os aspectos legais, os possíveis formatos, e as pesquisas acadêmicas mais significativas sobre o tema. Também apresentam-se os conceitos sobre a avaliação de desempenho, métodos, comentários e críticas específicas aos métodos listados. 
O terceiro capítulo apresenta o método utilizado na pesquisa, o instrumento aplicado, a definição das variáveis utilizadas, os conceitos relevantes, a definição dos respondentes e os procedimentos adotados na condução antes e durante sua execução.

Apresenta-se a síntese dos dados obtidos no capítulo quatro, bem como as suas análises.

As conclusões da pesquisa, suas limitações e sugestões para estudos futuros estão disponíveis no quinto capitulo.

As referências bibliográficas utilizadas no decorrer do estudo e os apêndices contendo documentos complementares à pesquisa são indicados ao final do trabalho. 


\section{FUNDAMENTAÇÃO TEÓRICA}

Conforme explicado no capítulo anterior, há interesse no estudo acadêmico das organizações, pois estas são essenciais ao nosso atual modo de vida (LAMCOMBE; HEILBORN, 2003, p.13). A lógica da competitividade entre organizações e nações intensificou-se no século XX e continua crescente no século XXI. Assim, estudos que averigúem os sistemas de maior sobrevivência e eficácia são desejáveis.

O sistema de franquias é um tema que tem despertado interesse de diversos estudiosos, como Lafontaine, Rizzo, Cherto, Cretella, Falbe, Vivian Silva, Campora, entre muitos outros no Brasil e no mundo. Dentro da área de estratégia das organizações, o tema avaliação de desempenho também foi estudado por diversos pesquisadores, por exemplo Martindell, Kaplan e Norton, H. Corrêa, Nelly, Franco-Santos, Sink e Tuttle, Zimmermann e Voepel. Entretanto, apesar da relevância de ambos os temas, são raros os trabalhos que os relacionem. Apresenta-se, a seguir, uma visão geral de cada um desses temas, sua importância acadêmica, e em seguida, sua relação. Abordam-se os assuntos em tópicos, conforme a seguinte estrutura:

- O sistema de franquias;

- O sistema de franquias no Brasil;

- Legislação no sistema de franquias;

- Formatos de franquias;

- Principais pesquisas sobre franquias;

- Razões para a avaliação de desempenho;

- Evolução da avaliação de desempenho;

- Abordagens prescritivas e modelos de avaliação;

- Tableau de bord;

- Martindell;

- Administração por objetivos - Drucker

- Corrêa

- Balanced Scorecard

- Skadia Navigator

- Comentários sobre os modelos

- Comentários sobre a avaliação de desempenho

- Avaliação de desempenho em franquias. 


\section{1 $\underline{\mathrm{O} \text { sistema de franquias }}$}

"O franchising é antes de tudo uma forma de distribuição de produtos e/ou serviços." (ANDRADE, 1993, p.2). O termo franchising refere-se a todo o sistema de franquias, incluindo franqueador, franqueado, produtos e serviços transacionados e distribuídos. No sentido mais básico, o termo franquia é um direito ou privilégio (FOSTER, 1995, p.13).

Destacam-se as franquias de formato de negócio, que "incluem o exercício de direito e obrigações contínuos nos termos de um contrato de franquia." (FOSTER, op. cit, p.13), ou seja, as que configuram principalmente uma relação de prestação de serviços entre franqueador e franqueado, distanciando-se do licenciamento.

O licenciamento ocorre por uma relação contratual de transferência do direito de uso de marca, por exemplo: a empresa Disney licencia o uso da marca "Pato Donald" para a confecção e venda de produtos, como agendas ou mochilas, por outras empresas. No sistema de franquias, as relações intensificam-se. Muitas vezes há prestação de serviços pelo franqueador ao franqueado, e em alguns casos ocorre a transferência completa ou parcial de um modelo de negócios, gerando no consumidor a impressão de que franqueador e franqueado são uma única empresa, já que se apresentam com uma única marca.

Um sistema de franquias clássico será composto por franqueador, que detêm a marca e a tecnologia do empreendimento; franqueados, que se propõem a instalar uma unidade operando com essa marca e tecnologia, produtos ou serviços padronizados; lojas próprias, operadas pelo franqueador; e lojas franqueadas, operadas pelos franqueados. Um exemplo para esse sistema é a rede Mc Donald’s.

Historicamente, as origens das franquias não estão bem definidas, com alguns autores sugerindo a criação do termo na idade média. O termo "Fran", de origem francesa, relacionava-se à idéia de liberdade, ou no caso, de uma liberdade para negociar. Ainda mais remotamente, o termo associa-se a distribuição de autorizações de coletas de impostos pela igreja católica (SILVA, 1999, p.51). Entretanto, atribui-se a Singer Sewing Machine, nos Estados Unidos da América (EUA), a criação do sistema que originou o que atualmente se conhece como um sistema de franquias. Por volta de 1851 ou 1852, essa fabricante de máquinas de costura, com sede na Nova Inglaterra, ao procurar aumentar seu acesso a 
mercados mais remotos dentro dos diversos Estados dos EUA, resolveu outorgar licenças de uso de sua marca e de seus métodos de operação, inclusive publicidade e técnica de vendas no varejo, aos comerciantes interessados em revender seus produtos (SILVA, op. cit, p.51).

Após esta iniciativa, outras empresas aplicaram a mesma estratégia, como a Coca-Cola e a General Motors ${ }^{4}$, que passou a usar o sistema para expandir sua revenda de automóveis, criando o conceito que, mais tarde, seria chamado concessionária de veículos, até então vendidos diretamente pelas fábricas (RISNER, 2001, p.4 apud MARQUES, 2006, p.36).

A difusão do sistema continuou pelos EUA no século XX. Em 1917, surgiram as primeiras franquias de mercearias, e em 1921, a primeira franquia de serviços puros: a locadora de veículos Hertz. Criou-se a primeira franquia de fast food em 1925, a A\&W. (CHERTO, 2006). De acordo com Rizzo (2006, p.10), as primeiras franquias confundiam a relação de franqueador com a relação de produzir e comercializar produtos, modelo dominante nos EUA até 1980. Nesse modelo conhecido como marca e produto, a transmissão de know-how limitase a exigências de padronização visual, ligadas a exposição da marca ou do produto.

Após a segunda guerra mundial, com o retorno dos combatentes interessados em se tornarem proprietários de negócios, a urbanização americana, a criação das Highways, e das viagens de carro, e também porque os financiamentos públicos junto à Small Business Administration eram mais facilmente obtidos por aqueles que ingressavam no sistema de franquias, o crescimento do número de franquias e de redes foi exponencial. Nos anos 50, a mudança dos hábitos alimentares, o papel da mulher, a televisão e a intensificação dos itens anteriormente citados, como a urbanização, levou o franchising a níveis sem precedentes. Matheuwson \& Winter (1985 apud SILVA, 1999, p.52) acrescentam a essas causas o aumento de renda dos consumidores, a potencialização do valor informacional das marcas, além de a televisão ter possibilitado a criação de marcas nacionais a custos mais baixos. Nesse período de maior expansão das franquias nos EUA, iniciaram a operação várias das mais famosas redes do mundo, como o Burger King, o Dunkin Donuts e o Mc Donald’s.

\footnotetext{
${ }^{4}$ O texto original cita o início da operação da General Motors com concessionárias no ano de1898, entretanto optou-se por suprimir esse trecho, por estar incorreto, já que o ano de fundação da GM é 1908; a informação repete-se em outros autores, como Cherto (2006, p.15) e Cretella (2003,p.48). O conceito de concessionária foi inventado por William Durant, mas não foi possível averiguar a data e em que empresa foi aplicado.
} 
Segundo Cherto (2006, p.19): "nos anos sessenta, o franchising pagou o preço do crescimento impetuoso que as redes de franquias tinham alcançado na década anterior: surgiram inúmeros franqueadores desonestos". Ao venderem franquias inexistentes e sumirem com o capital dos incautos, esses franqueadores começaram a sinalizar a necessidade de regulamentação no setor.

A era de franquias reguladas iniciou-se em 21 de Dezembro de 1979, quando o Federal Trade Commission, órgão governamental dos EUA, aprovou a regulamentação que exigia dos franqueadores a apresentação de informações aos potenciais franqueados, incluindo dados financeiros, histórico pessoal e da empresa, princípios da organização e valores a se investirem para ingresso no sistema (SHANE; FOO, 1999).

No Brasil, aprovou-se legislação similar em 1994. A regularização do setor e a obrigatoriedade de apresentar dados sobre a rede de franquias certamente aumentaram a necessidade de monitorar seu desempenho.

Uma pesquisa realizada em 1986 pela Associação Internacional de Franchising (International Franchising Association - IFA) constatou que o franchising de marca e produto apresentava declínio desde 1972, enquanto o franchising de formato de negócio apresentava crescimento (FOSTER, 1995, p.37). Atualmente, mesmo em países em desenvolvimento, muitas redes de franquias estão consolidadas, e setores como os de alimentação aparentam maturidade.

\subsection{O sistema de franquias no Brasil}

O sistema de franquias está presente em diversos setores da economia mundial. No Brasil, sexto lugar no ranking de franquias, o Guia da ABF indica aproximadamente 59.000 unidades franqueadas, 814 redes em atuação e 31,6 bilhões de faturamento, gerando 531 mil empregos diretos (ABF, 2006, p.39)

\footnotetext{
${ }^{5} \mathrm{O}$ dado apresentado pelo Guia conflita com o dado apresentado no site da ABF e esse é apenas um indicativo das discordâncias sobre quantos franqueadores atuam no território nacional. A ABF informa em seu site que existem 1.197 redes atuando em 2007 no país, mas lista apenas seus 619 sócios no Guia de Franquias on-line 2007. O Guia Completo de Franquias lista 621 franqueadores atuando em 2006 (Instituto Franchise, 2007). Rizzo (2006) apresenta o número de 1.109 franqueadores. A lista sofre variações, já que novas empresas iniciam operação nesse sistema com frequiência, e outras, como a Empório Botânico, continuam atuando, porém não mais através do sistema de franquias.
} 
O sistema de franquias no Brasil teve inicio de maneira desregulada, sendo praticado em acordos sem formalização legal por volta da década de 70. Segundo Silva (1999), a primeira franquia brasileira foi a escola de idiomas Yázigi. Muitas vezes, o sistema era visto como uma alternativa para a distribuição de produtos, como descreveu o proprietário do Boticário, Miguel Krigsner, ainda sem a clareza dos detalhes de um sistema de franquias. Por exemplo, de acordo com Andrade (1993, p.84), o Yázigi, fundado em 1950, começou a licenciar sua marca e método em 1963, mas apenas na década de 80 a administração tomou plena consciência que se tratava de aplicação do franchising.

Cretella (2003, p.53) acrescenta que as crises que o país enfrentou (choques do petróleo em 1973 e 1979, recessão econômica em 1981, 1983, 1990 e 2000), e o crescimento da população urbana, carente de serviços, fizeram do sistema de franquias uma opção para investidores e profissionais que buscavam segurança num investimento, para eles, menos suscetível ao ambiente de instabilidade.

A informalidade da maioria dos acordos, e mesmo da gestão, perdurou até 1987, quando se criou a Associação Brasileira de Franchising (ABF) e, no ano seguinte, o Instituto Brasileiro de Franchising (RIZZO e CHERTO, 1994). A partir desses eventos e da explosão do número de franquias decorrentes do plano cruzado, que passaram de 3.236 em 1985, para $5.061 \mathrm{em}$ 1987 (MAURO, 1999, p.85), intensificou-se a utilização de contratos formais entre franqueadores e franqueados. Em dezembro de 1994, o presidente Itamar Franco decretou a Lei 8.955, que regulamenta os contratos de franquia empresarial, disciplina as relações de franquia e licenciamento de uso de marca, além de definir franquia. Conforme o seu artigo 2:

Art. $2^{\circ}$ - Franquia empresarial é o sistema pelo qual um franqueador cede ao franqueado o direito de uso de marca ou patente, associado ao direito de distribuição exclusiva ou semi-exclusiva de produtos ou serviços e, eventualmente, também ao direito de uso de tecnologia de implantação e administração de negócio ou sistema operacional desenvolvidos ou detidos pelo franqueador, mediante remuneração direta ou indireta, sem que, no entanto, fique caracterizado vínculo empregatício (BRASIL, 1994).

A Lei ainda obriga o franqueador a apresentar a circular de oferta de franquia contendo diversas informações sobre o sistema oferecido e sobre a franqueadora. Observa-se que aspectos financeiros do franqueador devem constar nesse documento, assim a prática de medições financeiras é necessária na empresa franqueadora também por efeito da legislação. 
O fato é que o contrato de franquia é hoje uma realidade para a prática do franqueamento no Brasil. De acordo com Cherto:

Geralmente, o contrato celebrado entre a franqueadora e cada um de seus franqueados estipula que a primeira tem o poder de definir o modo pelo qual cada um desses franqueados deverá instalar, operar e até mesmo gerir seu próprio negócio e desempenhar as atividades que lhe competem, as quais serão desenvolvidas sob o controle, a supervisão, o monitoramento e a orientação da franqueadora e com a assistência desta, a quem cada franqueado pagará, direta ou indiretamente, de uma forma ou de outra, uma remuneração pela licença que lhe é concedida e pelos benefícios e recursos que aquela coloca ao seu alcance ao longo da vigência do contrato de franquia (2006, p.25).

Desta forma, pode-se afirmar que hoje, no Brasil, o sistema de franquias é também uma relação contratual entre organizações.

Atualmente, mesmo o setor público utiliza o sistema de franquias para provisionar alguns serviços à população, como é o caso dos Correios. (CRETELLA, 2003)

Vale frisar, a fim de elucidar o conceito, que a partir de 1998, o termo franquia começou a ser aplicado também a franquia social (MAURO, 1999, p.95), a qual se assemelha a uma franquia, pois trata da replicação de um modelo testado, todavia testado quanto à responsabilidade social e não devido ao seu resultado comercial ou financeiro. Um exemplo de franquia social é o programa Formare, da Fundação Iochpe, programa de formação e capacitação profissional para jovens carentes instalado dentro de empresas que adquirem a franquia, com a metodologia da Fundação. Nesse exemplo, ocorre também o pagamento de uma mensalidade de manutenção para o projeto (IOCHPE, 2007).

\subsection{Formatos de franquias}

O processo de consolidação do sistema de franquias, com a passagem de, aproximadamente, 8.000 unidades franqueadas em 1990 para 45.000 uma década depois, foi acompanhado por mudanças nos formatos e características das franquias (MAURO, 1999, p.86). Cherto e Rizzo (1991, p.5) fazem um resumo da evolução e das características das gerações de franquias em função dos serviços prestados pelo franqueador à rede franqueada. Observa-se que os diferentes formatos ainda operam, e a divisão em gerações apenas indica a cronologia dessa mudança, sem considerar uma tipologia como superior à outra. 
De acordo com os autores, as franquias de primeira geração estão associadas à outorga pelo franqueador da autorização de uso da marca, em conexão com a revenda de certos produtos e/ou prestação de serviços, fornecidos pelo franqueador. Nesse modelo, raramente o franqueador faz mais do que fornecer um projeto arquitetônico e um padrão visual; na maioria, recebe do franqueador somente através do valor cobrado pelo produto ou serviço do qual o franqueado é um distribuidor, ou seja, há pouca transferência tecnológica. A rede de franquias não é o canal único de escoamento e distribuição do franqueador e, na maioria das vezes, nem mesmo é o principal. Segundo Mauro (op. cit., p.99), "normalmente não existe o contrato de franquia, o que por si só já eliminaria a classificação como franquia”. Segundo Rizzo (2006, p.11), nesse estágio as relações entre franqueador e franqueados são frágeis.

As franquias de segunda geração assemelham-se às de primeira, visto que também prestam poucos serviços aos franqueados e mantêm o foco na distribuição dos produtos ou serviços, contudo, segundo Cherto e Rizzo (1991), as lojas da rede formam o canal exclusivo de distribuição do franqueador. Rizzo (2006) ainda apresenta outra definição para as franquias de segunda geração: aquelas em que o franqueador exige exclusividade do franqueado, mas não oferece a mesma.

As franquias de terceira geração são também conhecidas por franquias de formato de negócio. Tais franquias incluem a transferência de tecnologia que o franqueador desenvolveu e testou na prática (através de unidades piloto), organizou e sintetizou. O planejamento da operação e administração da unidade é fornecido completamente pelo franqueador. Em outras palavras, o foco do franqueador não é mais na distribuição de produtos ou serviços, mas sim na prestação de serviços aos franqueados. Entre esses serviços, incluem-se: análise do ponto, assistência de implantação, treinamento, orientação, manuais e unidade piloto. Rizzo considera esse o modelo de menor risco, e encerra sua classificação nesse nível (2006, p.12). 
Tabela 1 - Gerações no Franchise

\begin{tabular}{|c|c|c|c|}
\hline Tipo & $\begin{array}{l}\text { Relação Franqueador } \\
\text { Franqueado (foco principal) }\end{array}$ & $\begin{array}{l}\text { Quanto ao } \\
\text { Contrato }\end{array}$ & $\begin{array}{l}\text { Padronização } \\
\text { e Marca }\end{array}$ \\
\hline Primeira & $\begin{array}{l}\text { Fornecimento de produtos sem } \\
\text { exclusividade }\end{array}$ & Pode não existir & Pode existir \\
\hline Segunda & $\begin{array}{l}\text { Fornecimento de produtos com } \\
\text { exclusividade (canal único) }\end{array}$ & $\begin{array}{l}\text { Exigência de } \\
\text { exclusividade de } \\
\text { uma das partes. }\end{array}$ & $\begin{array}{l}\text { Estabelece } \\
\text { padrão visual }\end{array}$ \\
\hline Terceira & Prestação de serviços. & $\begin{array}{l}\text { Lista obrigações } \\
\text { para as partes }\end{array}$ & $\begin{array}{l}\text { Transferência } \\
\text { de kwon-how. }\end{array}$ \\
\hline Quarta & $\begin{array}{l}\text { Prestação de serviços, maior } \\
\text { preocupação com a rede e não } \\
\text { apenas com o franqueado. }\end{array}$ & $\begin{array}{l}\text { Lista obrigações } \\
\text { para as partes }\end{array}$ & $\begin{array}{l}\text { Transferência } \\
\text { de kwon-how. }\end{array}$ \\
\hline Quinta & $\begin{array}{l}\text { Prestação de serviços, franqueados } \\
\text { participam da gestão da rede } \\
\text { através de conselho }\end{array}$ & $\begin{array}{l}\text { Lista obrigações } \\
\text { para as partes }\end{array}$ & $\begin{array}{l}\text { Transferência } \\
\text { de kwon-how. }\end{array}$ \\
\hline
\end{tabular}

Mauro (op. cit.) ainda acrescenta as franquias de quarta e quinta geração. Para o autor, essas incluem a prestação de outros serviços à rede franqueada, como jornal da rede, canal de comunicação aberto e planejamento estratégico da rede nas franquias de quarta geração. Já nas de quinta geração, há a presença de um conselho de administração de franqueados, a contratação de um ombundsman para monitorar o comportamento do franqueador, e sistema de recompra e revenda de unidades com problemas.

Essa classificação ainda não se consolidou entre os pesquisadores, mas certamente a literatura acadêmica separa as franquias de formato de negócio (terceira, quarta e quinta gerações) das franquias com foco na distribuição de produtos.

\subsection{Principais pesquisas sobre franquias}

O interesse pelo franchising dentro no universo acadêmico relaciona-se ao estudo do empreendedorismo, à sua importância econômica e também à análise das relações entre franqueadores e franqueados. As franquias apresentam maiores taxas de sucesso e sobrevivência do que os empreendimentos realizados por empreendedores sem suporte de um franqueador. Conforme a tabela 2, as taxas de sobrevivência de novos empreendimentos são da faixa de $71 \%$ para o primeiro ano de atividade (BEDÊ, 2005); já em franquias, mesmo após um período de 5 anos, apenas 15\% dos franqueados encerram os negócios (ABF, 2006). 
Convém observar que descontinuar uma loja de franquia é algo muito ruim para o franqueador, e pode trazer prejuízos à marca, assim, pode ser que os franqueadores, prevendo o fechamento de uma das lojas, a recomprem por um preço baixo e a repassem a um novo franqueado, caso acreditem ser o problema gerencial, ou mesmo que assumam as operações, se acreditarem que a loja tenha possibilidade de sucesso (LAFONTAINE, 1992).

Tabela 2 - Mortalidade de negócios

\begin{tabular}{|l|c|c|c|}
\hline \multicolumn{4}{|c|}{ Taxa de Mortalidade de Negócios } \\
\hline$\%$ mortalidade até o final do & $1^{\underline{0}}$ ano & $5^{-0}$ ano & $10^{-0}$ ano \\
\hline Negócios de varejo & $26 \%$ & $75 \%$ & $83 \%$ \\
\hline pequenos negócios & $23 \%$ & $71 \%$ & $80 \%$ \\
\hline Franquias & $3 \%$ & $8 \%$ & $9 \%$ \\
\hline \multicolumn{2}{|c|}{ Dados: Rizzo Franchise, Dun \& Bradstreet, IFA International Franchise Association } \\
\hline
\end{tabular}
Fonte: RIZZO, 2006, p. 37.

A importância econômica das franquias no Brasil, segundo Marcus Rizzo (2006, p.17), é evidenciada pelo faturamento do setor de 172 bilhões de reais, em 2004, correspondendo a um décimo do PIB brasileiro.

Conforme apontado por Silva, as pesquisas que focalizam o sistema de franquias, e "seu papel enquanto uma função que regula a relação entre franqueador e franqueado, é bastante estudada pela teoria econômica, em especial pela Teoria de Agência.” (SILVA, 1999, p.9) Há também diversos estudos empíricos sobre essa relação, como Lafontaine (op. cit.), Alon (2001), Jensen and Meckling, (1976 apud. Alon 2001, p.109), Frazer (1998) entre outros.

A Teoria de Agência e a economia dos custos de transação desenvolveram-se a partir dos trabalhos sobre a firma do vencedor do prêmio Nobel de economia de 1991, Ronald Coase. O trabalho de Coase (1937) centrou-se no olhar sobre os contratos, os custos de transação e sobre as externalidades que explicavam a existência das empresas que, em uma análise simples dos pressupostos neoclássicos, nem mesmo deveriam existir, evidenciando o descolamento entre teoria e prática da época. Surgia assim a Nova Economia Institucional, que teve contribuições de outros autores, como Knight, Barnard, Hayek, Commons, entre outros (SILVA, 1999, p.18).

Jensen e Meckling (1976, p.5) apresentam um resumo da Teoria da Agência, e de suas implicações principais: 
Nós definimos uma relação de agência como um contrato em que uma ou mais pessoas (o principal) acertam com outra(s) pessoa(s) (o(s) agente(s)) a realização de um serviço em benefício do primeiro, o que envolve delegar ao agente algum poder de decisão. Se ambas as partes desta relação procuram maximizar seus ganhos, há boas razões para acreditar que o agente não vai sempre atuar no melhor interesse do principal.

Além disso, em algumas situações, o principal gastará recursos adicionais, (custos de monitoramento) para garantir que o agente não tomará certas atitudes prejudiciais ao principal ou para garantir compensação, caso ele tome essas atitudes.

No entanto, é geralmente impossível para o principal ou para o agente, a custo zero, assegurar que o agente irá tomar a decisão ótima do ponto de vista do principal. Na maioria das relações de agencia, o principal e o agente vão incorrer em custos de monitoramento (pecuniários e não pecuniários) e adicionalmente existirão algumas divergências entre as decisões do agente e aquelas que maximizariam o bem-estar do principal. ${ }^{6}$

A Teoria da Agência, embora se desenvolva a partir de estudos sobre assimetria de informação, sendo portanto inovadora, ainda contempla a racionalidade plena dos indivíduos, um dos princípios das teorias neoclássicas atualmente questionados. Já a Economia dos Custos de Transação considera também a racionalidade limitada dos agentes econômicos, aproximando-se ainda mais da realidade.

A versão convencional da teoria da agência baseia-se em uma concepção empobrecida da ação humana, que pressupõe escolhas racionais entre as linhas de conduta possíveis em cada situação. [...]

A teoria da agência permite identificar problemas e contradições centrais nas relações entre principais e agentes e ajuda a entender por que certas soluções são eficazes, mas não é suficiente para explicar os arranjos específicos que se adotam na prática. Quase sempre há vários arranjos que seriam satisfatórios para ambas as partes porque, como Herbert Simon (1957) argumentou, na maioria das vezes as pessoas se dão por satisfeitas com medidas que surtem efeito e não seguem buscando a melhor de todas as soluções para cada problema que enfrentam, o que geralmente não vale a pena. A teoria da agência ajuda a delimitar o conjunto dos ajustes viáveis entre principais e agentes, mas não explica por que eles chegam a um deles e não a outro. (MONSMA, 2000, p.84)

\footnotetext{
6 No original: We define an agency relationship as a contract under which one or more persons (the principal(s)) engage another person (the agent) to perform some service on their behalf which involves delegating some decision making authority to the agent. If both parties to the relationship are utility maximizers, there is good reason to believe that the agent will not always act in the best interests of the principal.

In addition in some situations it will pay the agent to expend resources (bonding costs) to guarantee that he will not take certain actions which would harm the principal or to ensure that the principal will be compensated if he does take such actions.

However, it is generally impossible for the principal or the agent at zero cost to ensure that the agent will make optimal decisions from the principal's viewpoint. In most agency relationships the principal and the agent will incur positive monitoring and bonding costs (non-pecuniary as well as pecuniary), and in addition there will be some divergence between the agent's decisions 8 and those decisions which would maximize the welfare of the principal.
} 
A Teoria de Agência é um dos temas recorrentes quando se discute pesquisa em franquias, devido à relação franqueador e franqueado, que se assemelha à relação principal e agente. $\mathrm{O}$ franqueado é agente do franqueador, já que o representa e distribui seus produtos, serviços e marcas, mas não necessariamente busca o melhor para o franqueador (principal), podendo, por exemplo, adquirir produtos de um fornecedor não autorizado pelo principal, para burlar o pagamento de royalties (porcentagem sobre as vendas).

Nesse sentido, há o que se convencionou chamar de risco moral (moral hazard ${ }^{7}$. As situações de risco moral no sistema de franquias ocorrem quando, por exemplo, um franqueado de uma rede de cafés de qualidade, que regula a qualidade dos fornecedores, opta por comprar pó de café de baixa qualidade, a um preço mais baixo, de um fornecedor não autorizado pelo franqueado, e utilizá-lo em sua unidade como o típico café da rede. Para o franqueado, há um ganho, pois poderá diminuir os valores pagos como royalties sobre percentagem de vendas, porque o franqueador apenas monitora o volume de café entregue pelos fornecedores oficiais e as vendas declaradas do franqueado, então há condições para mentir e dizer que houve um menor volume de vendas, sem ser apanhado. Contudo, o café de qualidade inferior poderá prejudicar a imagem da marca com os clientes. Monitorar esse comportamento implicará em aumento de custos para o franqueador, diminuindo sua saúde financeira, e provocando perda de competitividade para toda a rede. Felizmente para esse franqueador, seus concorrentes sofrem do mesmo dilema. Desta forma, ocorrerá uma perda econômica decorrente do monitoramento para a sociedade como um todo, que terá de pagar mais caro por um serviço que não agrega valor ao produto final. (MATHEWSON; WINTER, 1985)

Cabe observar que nem sempre o franqueador exerce o papel de principal. Em situações como a gestão dos fundos de propaganda, o franqueador aparece como agente, já que controla os

\footnotetext{
${ }^{7} \mathrm{O}$ risco moral ou perigo moral é muito discutido em economia, especialmente nos contratos de seguro. Um exemplo simples é dado pelo mercado de seguros. Imagine o dono de um veículo que contrata um seguro de carro, e depois da contratação, passa a ter um comportamento mais arriscado, como dirigir com menos cuidado, ou passar a estacionar o carro na rua, ao invés de no estacionamento. Antes, esse proprietário temia que o carro fosse roubado, e minimizava riscos, mas agora o risco do roubo está coberto pelo seguro. Esse comportamento é prejudicial ao segurador, pois o risco de roubo do veículo aumentará, e o preço do seguro foi calculado nessas condições. Se diversos segurados agirem dessa forma, a seguradora pode ter problemas e, portanto, terá que aumentar o preço do seguro. No entanto, para os segurados, é interessante não pagar mais estacionamento e, desta forma, o mercado de seguros pode acabar inviável. A solução, no caso dos seguros, é a taxa de franquia ou prêmio, que obriga o segurado a compartilhar parte do risco do roubo e diminui a chance de risco moral (VARIAN, 2003, p.716).
} 
recursos dos franqueados e decide em quais mídias e locais aplicar-se-ão tais recursos (BHATTACHARYYA; LAFONTAINE, 1995).

Com a avaliação de desempenho dos franqueados pelos franqueadores e de que forma esta se alinha à estratégia da rede, a Teoria de Agência permanece como um ponto importante, porque a avaliação, através de indicadores, e o alinhamento estratégico da rede estão sujeitos aos efeitos da relação principal e agente e, dessa forma, uma série de efeitos pode influenciar os resultados da avaliação e sua efetiva aplicação. Deve-se considerar que:

- Normalmente, os indicadores constroem-se partindo-se do pressuposto de que os responsáveis pelo levantamento dos dados não vão mentir ao fornecerem informações.

- Se há vantagens em trapacear o sistema (risco moral), há o risco de que algum franqueado o faça. (MATHEWSON; WINTER, 1985)

- Os franqueadores provavelmente estão cientes do risco moral, e é possível que apliquem outros tipos de monitoramento a fim de checarem as informações fornecidas, o que pode provocar aumento de custos de monitoramento. (MATHEWSON; WINTER, op. cit.)

- Há também a possibilidade de ocorrerem avaliação e monitoramento, tendo como preocupação principal o risco moral, e não a avaliação de desempenho da rede e sua gestão estratégica.

- Como também há risco moral por parte do franqueador, que poderá agir como oportunista, supõe-se que instrumentos que deveriam servir para aprimorar a rede e dar clareza estratégica ao grupo, como as reuniões de franqueados, correm o risco de serem desvirtuados para instrumentos de monitoramento e cobrança sobre o franqueador.

- Todas as avaliações têm o risco de gerar conflitos, num sistema sujeito à relação agente e principal, esse risco aumenta, podendo inclusive atrapalhar a relação pessoal dos participantes da rede.

Agrawal e Lal (1995, p.220) encontraram evidências de que a preocupação com o desempenho dos fraqueados e as atividades de monitoramento pelos franqueadores é positivamente correlacionada com a taxa de royalty, indicação de risco moral nos contratos de franquia.

Finalmente, deve-se observar que também se utiliza a teoria da agência para explicar a opção pelo franchising em detrimento da opção de se expandir por meio de lojas próprias, por diferentes autores, como Lafontaine (1992), Shelton ( 1967 apud. Michael 2003) e Kruger (1991 apud. Michael 2003, p.64). Segundo eles, o monitoramento dos franqueados tem um 
preço alto, mas esse preço ainda é menor do que o monitoramento de uma equipe de gestores contratados em lojas próprias, pois o franqueado, bem ou mal, investiu recursos na franquia, portanto tem maior interesse no sucesso desta do que um gerente contratado.

Evidências desse fato foram indicadas por Lafontaine (1992), em um estudo em que comparou lojas próprias e franqueadas, considerando a distância da unidade até a sede do franqueador. $\mathrm{O}$ autor percebeu que a probabilidade de uma loja da rede ser uma unidade franqueada e não uma loja própria aumenta à medida que cresce a distância desta até o franqueador. Se a distância aumenta, crescem as dificuldades de monitoramento das lojas próprias, optando-se pelo sistema de franquias (LAFONTAINE, 1992). Como a declaração de Silva (1999) sobre uma cadeia de fast food: "Para a rede Habib's, entretanto, o fato de os investimentos serem assumidos pelo próprio franqueado o tornaria mais motivado a trabalhar segundo as normas e padrões estabelecidos, favorecendo a valorização da marca." (SILVA, 1999, p.106).

Outros temas dentro das Ciências Sociais também estudam o franchising, em especial, a teoria da escassez de recursos, que discutem a decisão de franquear em comparação à decisão de se expandir por meio de lojas próprias, justificando essa decisão pela maior facilidade para obter recursos e crescer com menor risco. Finalmente, deve-se notar que "as visões são complementares e não contraditórias, quando se considera a escassez de recursos como um problema de curto prazo e a agência um problema de longo prazo."8 (MICHEL, 2003, p.64).

O trabalho de duas empresas em parceria, como ocorre num sistema de franquias, traz provavelmente alguns ganhos e benefícios. Por exemplo, pode-se considerar que a inovação tem mais probabilidade de ocorrer numa rede de franquias, do que em uma rede de lojas próprias de mesma configuração. Os franqueados são empreendedores, os gerentes de lojas próprias normalmente não são. Na visão de Schumpeter (1982), os empreendedores são responsáveis pela maioria das inovações. Assim, mesmo considerando a essência de uma franquia como a repetição de um sistema e a padronização de produtos e serviços, é natural imaginar que seja mais fácil para o franqueado testar um novo layout ou produto numa loja franqueada, do que um gerente de uma loja de cadeia. Também a relação de parceria facilita a crítica honesta do franqueado, em relação à de um gerente, que temeria desagradar o patrão

\footnotetext{
${ }^{8}$ No original: The two views are complementary, not contradictory, especially if resources are a problem in the short run and agency a problem in the long run.
} 
(ANDRADE, 1993, p.165). Caso a inovação mostre-se bem sucedida, o franqueador incentivará seu uso através da rede. Pode-se argumentar que o franqueador não é exatamente o empreendedor de Schumpeter, mas trabalhos como o de Marcelo Andrade (1993) evidenciam a colaboração dos franqueados no processo de inovação, como proponentes ou críticos às inovações. Outro exemplo para o uso do sistema de franquias é o maior comprometimento que se espera do franqueado, se comparado ao de um gerente, empregado contratado, afinal o franqueado é também proprietário da franquia, logo deve ter maior compromisso com o resultado. Entretanto, a ausência de sistema de avaliação de desempenho organizacional para o conjunto do sistema de franquias torna impossível avaliar os benefícios advindos do fato de as empresas trabalharem de forma conjunta.

\subsection{Razões para a avaliação de desempenho}

A avaliação de desempenho tem como proposta melhorar a performance da organização ou do sistema. Esse processo desenvolve-se através da medição ${ }^{9}$. As organizações medem porque o processo informa aos gestores quais as capacidades do sistema, e os níveis de performance esperados, dos processos e dos sistemas da organização. (DEMING, 1986, p.341)

A avaliação de desempenho organizacional tem novamente despertado o interesse acadêmico, especialmente após a constatação de que os indicadores financeiros não eram suficientes para a compreensão da organização, e também devido ao resgate do tema pela sua importância para a estratégia. No entanto, esse processo não é novidade, e intensificou-se com a reengenharia, pois

[...] as empresas que tiveram sucesso com a reengenharia primeiro procuraram alcançar o entendimento profundo do processo atual, fazendo perguntas como as seguintes:

- Como é o processo atual?

- Quanto custa o processo atual?

- Quanto tempo o processo leva?

- Que resultados estamos conseguindo?

(FUREY apud. MAXIMIANO, 2002, p.489).

Entretanto, ao considerar a avaliação de desempenho, a construção de indicadores, e o alinhamento estratégico, recorda-se a ressalva de Mintzberg (2006, p.136):

\footnotetext{
${ }^{9}$ DEMING usa o termo controle estatístico.
} 
Observe o tipo de conhecimento envolvido no pensamento estratégico: não o conhecimento intelectual, não relatórios analíticos ou fatos e números abstratos (embora eles certamente possam ajudar), mas o conhecimento pessoal, compreensão íntima, equivalente ao sentimento do artesão pela argila. Fatos estão disponíveis para todos; este tipo de conhecimento não está. Sabedoria é a palavra que melhor captura isso. Mas sabedoria é uma palavra que acabou perdida nas burocracias que criamos para nós mesmos, nos sistemas projetados para distanciar os lideres dos detalhes operacionais. ${ }^{10}$

Os sistemas de avaliação apresentam assim limitações inerentes a sua natureza. Hourneaux Jr. (2005, p.13), no mesmo sentido, explica que os sistemas de avaliação de desempenho focam apenas a avaliação de desempenho organizacional e não o controle gerencial de desempenho, mais amplo, e que abrange muito mais do que apenas a mensuração de desempenho e o alinhamento estratégico das organizações.

Atualmente há muita preocupação com a medição de performance, inclusive em outros setores, como o governamental. No entanto, como diz R. Behn (2003, p.586), ao comentar as avaliações pelo setor público: "Por que se deve medir a performance? Ora, porque medir performance é bom. E como sabemos que medir performance é bom? O setor privado mede performance, e qualquer um sabe que ele é melhor gerenciado do que o público."11. Naturalmente, segue-se a pergunta: E por que as organizações privadas medem a performance? Há, segundo Konntz e O’Donnell, três razões fundamentais para que se tenha um controle do desempenho geral da organização:

Em primeiro lugar, assim como o planejamento geral tem que se aplicar aos objetivos da empresa ou de suas principais divisões, também os controles totais têm que ser aplicados. Em segundo lugar, a descentralização da autoridade - especialmente em divisões de produto ou território - cria unidades semi-autônomas, e estas têm que ser submetidas, pelo menos a controles gerais, para evitar o caos que resultaria de uma autonomia completa. Em terceiro lugar, os controles gerais permitem medir o esforço total do administrador numa área integrada, em vez de medir somente partes deste esforço. (KOONTZ; O’DONNELL, 1969, p.770 apud HOURNEAUX, p.17).

Essas afirmações são reforçadas pela visão de marketing que defende que as organizações atinjam seus objetivos quando satisfazem os clientes com mais eficácia e eficiência que seus

\footnotetext{
${ }^{10}$ Nota do autor: grifo nosso.

${ }^{11}$ No original: Why measure performance? Because measuring performance is good. But how do we know it is good? Because business firms all measure their performance, and everyone knows that the private sector is managed better than the public sector.
} 
competidores (KOTLER, 1988, p.37). Se eficácia refere-se ao quanto se respondem tais solicitações dos clientes, e eficiência refere-se ao uso econômico dos recursos para atingir um nível de satisfação dos clientes, então se evidenciam duas importantes dimensões da avaliação de desempenho e, simultaneamente, justifica-se sua aplicação (NEELY, 2005).

Além dessas razões, há uma lista de prováveis conseqüências caso a organização não se preocupe em avaliar seu desempenho. Segundo Halachmi (2005, p.503): "Se você não pode medir, você não pode entender, e aquilo que não se entende, não se controla. Aquilo que não se controla não pode ser melhorado. ${ }^{12 ”}$ A proposição é exagerada, pois certamente há melhoramentos mesmo em situações de descontrole, contudo dá uma dimensão da importância do tema. O autor ainda agrega outras razões para o uso da avaliação de desempenho: a necessidade de diferenciar sucesso e fracasso e, portanto, de dificuldade de recompensar o sucesso ao invés do erro, além das dificuldades de aprendizagem individual e organizacional que decorrem disso. Finalmente, Halachmi faz uma observação, pertinente também para o caso das franquias: "se os funcionários, os colaboradores ou os parceiros sabem da sua intenção de avaliar uma tarefa, eles a realizarão".

\subsection{Evolucão da avaliacão de desempenho}

Historicamente, pode-se considerar que a visão positivista, desenvolvida por Comte e sua ligação com o experimentalismo científico, influenciou os primeiros administradores da dita administração científica. Por essa visão, a gradativa construção da ciência, especialmente reforçada após o método científico de Descartes, e as diversas descobertas e formulações dos séculos XVIII e XIX, levaria a humanidade até um patamar de civilização onde a felicidade seria um bem comum e disponível a todos (GIANETTI, 2002).

Grande parte dessa revolução científica alicerçava-se na evolução da matemática e dos métodos de medição e inferência, como os desenvolvidos por Galton (BERNSTEIN, 1997, p.165). Sem a evolução dos instrumentos de medição, como o relógio de pêndulo, por exemplo, a criação das teorias da física teria sido inviável. Essa visão de mundo científica refletiu-se na administração, e certamente inspirou administradores como Taylor e Fayol, que começaram a se preocupar com conceitos como medição da produtividade e controle das

\footnotetext{
${ }^{12}$ No original: if you cannot measure it you do not understand it; if you cannot understand it you cannot control it; if you cannot control it you cannot improve it.
} 
operações. Conforme Maximiano (2002, p.126), Fayol já entendia o controle como em três diferentes níveis, em função da hierarquia. Num nível, há o controle operacional, que focaliza as atividades e consumo de recursos nas áreas funcionais, realizado por meio de cronogramas e orçamentos. No nível seguinte, há o controle administrativo, no qual produzem-se as informações para a tomada de decisão das áreas funcionais, como marketing e produção, e num terceiro e último nível, há o controle estratégico, com duas funções: 1- acompanhar a avaliar o desempenho da organização na realização de suas missões, e 2 - acompanhar os fatores externos que influenciam a organização.. O controle estratégico não é exatamente a avaliação de desempenho global, sendo mais restrito, todavia muitas vezes esses conceitos confundem-se na literatura e suas conexões são evidentes. Controle é um conceito vinculado aos conceitos de restrição e adequação, mais do que a avaliação, vinculada à formulação estratégica.

O primeiro modelo de avaliação de desempenho é o Tableau de Bord, o qual já previa o uso de indicadores estratégicos (LEBBAS, 1994), datado no início do século XX.

Historicamente, entretanto, a maioria das empresas dessa época que procedia à avaliação de desempenho por indicadores físicos e de produção utilizava processos similares aos propostos por Frederick Taylor, além de indicadores contábeis. No início do século XX, a invenção do indicador financeiro Return On Investment (ROI) pela Du Pont Company repercutiu de forma que esse e outros indicadores financeiros passaram a ser aplicados quase exclusivamente até os anos 60, quando houve o movimento da qualidade (JOHNSON; KAPLAN, 1993, p. 72$73)$.

Ocorreu uma evolução dos mecanismos quantitativos de gestão da organização, influenciada pela mentalidade dominante nos administradores em cada momento e cultura. Ilustrativamente, a revolução da qualidade provocada pela industrialização japonesa levou à busca de formas de controle da qualidade dos produtos e da produção, em níveis sem precedentes e em aspectos que antes não se consideravam como possíveis. A utilização de definições operacionais, por exemplo, foi estimulada por autores como Deming (2006, p.276); da mesma forma, nesse processo, atividades de monitoramento e controle intensificaram-se dentro da escola chamada Administração da Qualidade Total. (MAXIMIANO, 2002, p.170) Conseqüentemente, o uso de indicadores quantitativos intensificou-se, também, nos processos de avaliação. 
Em certa medida, os processos de avaliação são questionáveis, já que os indicadores são um reflexo da realidade, por meio do qual se busca apreender a situação da organização. De acordo com Scriven (2001, p.28), avaliador profissional:

O detalhe complexo, o trabalho árduo, na teoria da avaliação envolve desfazer a maneira na qual a avaliação é um empreendimento difundido, multifuncional, multifacetado, e que envolve diversos papeis e participantes. Depende do contexto em alguns casos, e independe em outros, enviesado numa situação, objetivo noutra. Ela é parte da busca por conhecimento que inclui substanciais partes de ciência, tecnologia, legislação, ética, e outras disciplinas humanas. Todos nós, ao longo de nossa vida pessoal ou profissional, participamos de diversos papéis como na avaliação, como avaliados, avaliadores, usuários da avaliação ou comissários. ${ }^{13}$

Após levantamento das metodologias existentes até o ano de publicação de sua tese, Corrêa, corrobora essa linha de raciocínio ao afirmar: “ embora alguns autores apresentem modelos estruturados, estes trazem no seu conteúdo uma parcela de subjetividade, como se pode notar, por exemplo, na definição de indicadores e padrões.” (CORRÊA, 1986, p.99).

Martindell (1950, p.267), autor que discutiu a avaliação da organização e do desempenho organizacional nos anos que seguiram a segunda guerra mundial, por meio da análise de empresas como a General Motors, ou a Humble Oil, já dizia que esse processo era complexo e inconstante, pois as organizações estão em freqüentes mudanças e, assim, a avaliação consistia na mensuração de fatores inconstantes. O autor inovou ao propor, por exemplo, a avaliação da diretoria das companhias, por meio de aspectos como “ visão, integridade, e experiência de negócios dos membros. A idade média do corpo da direção é uma das preocupações fundamentais." ${ }^{14}$ (ibid. p.269).

A sugestão supracitada de Martindell revelava que a idade média dos diretores pode ser um indicativo da qualidade desse grupo, o que fazia sentido na época de sua formulação, mas

\footnotetext{
${ }^{13}$ No original: The complex detail, the hard work, in evaluation theory, involves unpacking the way in which evaluation is a pervasive multifunction, multi-role, multi-player enterprise: context-dependent here, contextindependent there, biased here, objective there. It is part of the great knowledge seeking effort that includes substantial parts of science, technology, law, ethics, and other humanistic disciplines. And all of us, throughout all our personal and professional lives, play many roles in evaluation - as evaluators, as evaluees, and as commissioners or users of evaluation.

${ }^{14}$ No original: Evaluation of the board of directors resolves itself into estimating the wisdom, integrity, and business experience of each individual member. The average age of board members is of primary concern.
} 
pode não fazer hoje. Ela evidencia que não há exatamente um consenso sobre quais os fatores mais importantes para se avaliar o desempenho de uma empresa. Havia então um desejo de quantificar esses fatores, mas também um temor que essa quantificação gerava resultados imprevistos e consequiências desastrosas, como o aumento de custos, sem reflexos significativos na gestão ou na estratégia.

Já em 1954, Peter Drucker sugeriu que a solução para os conflitos decorrentes do desejo de quantificar os fatores associados à gestão e as consequiências imprevistas dessa quantificação é um conjunto de objetivos e medidas balanceado, considerando oito áreas: "posição de mercado, inovação, produtividade, recursos financeiros e naturais, lucratividade, atuação e desenvolvimento dos administradores, desempenho dos trabalhadores e responsabilidade pública”. (DRUCKER, 1981, p.60).

Segundo Neely, trinta anos após as idéias de Drucker, os mesmos temas, ou seja, "o desejo de quantificar e as suas conseqüências imprevistas" (NEELY, 2005, p.1266) continuavam em discussão, por diferentes autores como Johnson e Kaplan, Hayes e Abernathy e pela obra de Chandler, The invisible Hand, entre outros. Diferentes sugestões foram apresentadas, e modelos e métodos, desenvolvidos por diversos autores, como revela a revisão elaborada por Hourneaux (2005, p.23). Ao todo, o autor listou 13 modelos e suas características principais, iniciando com o Tableau de Bord, desenvolvido na França no início do século XX e indo até o final do século XX, com o SIGMA Sustainability Scorecard. A profusão de métodos liga-se à necessidade de se responder a pergunta dominante nos anos 80 em diante: como se desenvolver e se implantar um sistema balanceado de avaliação de desempenho organizacional? Hourneaux; Maximiano e Corrêa, (2006) consideram esses modelos como abordagens prescritivas. Hourneaux Jr. e Corrêa (2007) apontam o crescimento da literatura sobre o assunto no final do século XX, mas insistem que ainda há barreiras na utilização de sistemas de avaliação, especialmente no que tange as pessoas responsáveis pelo processo.

A pesquisa realizada por Neely (2005) por meio do cruzamento de citações, contagem de artigos e citações por autores, na base de dados SIS Web of Science, evidencia também que há muitos autores discutindo o assunto. Aproximadamente 17.000 autores escreveram sobre os termos performance measure, mas há apenas quatro autores com mais de 100 citações na base de dados pesquisada. Segundo o autor, isso indica que o campo de pesquisa ainda não se estruturou, e provavelmente não há muitas idéias dominantes. Ainda segundo o autor, os 
artigos de Kaplan e Norton são os textos recentes com maior número de citações, o que explicita o Balanced Scorecard como modelo dominante para construção de um sistema de avaliação de performance.

O Balanced Scorecard foi proposto em 1992 por Robert Kaplan e David Norton e obteve rápida aceitação devido a um novo olhar sobre os sistemas de avaliação de desempenho. Os autores argumentam que apenas indicadores financeiros focavam fundamentalmente os eventos do passado, sendo portanto ferramentas incompletas, ou até mesmo inadequadas para os gestores. "Mas quais seriam os indicadores apropriados para a performance futura? Se os indicadores financeiros estavam levando as organizações a fazer as coisas erradas, que tipo de indicadores as levaria a fazer do jeito certo? A resposta revelou-se óbvia: medir a

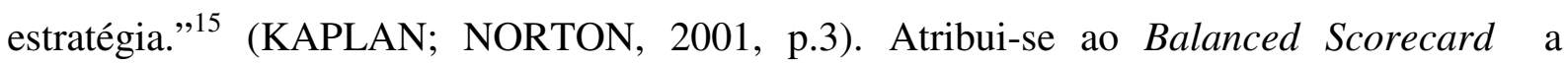
capacidade de se alinharem estrategicamente a organização e seus diversos níveis e focar na direção dos objetivos.

Kaplan e Norton listaram casos de sucesso em que o Balanced Scorecard atingiu o seu propósito e ajudou a realizar estratégias bem sucedidas. Por outro lado, diversos autores criticaram-no, listando diversos casos de insucesso em sua consecução, como apontou levantamento feito por Paranjape, Rossiter e Pântano (2006, p.7). As críticas explicitam indicadores em excesso ou inapropriados, execução ineficiente pela gerência, ou uma ênfase ainda exagerada em aspectos financeiros (DENT, 2005 apud. PARANJAPE et. al. 2006). Voepel et. al. (2006, p.57), em artigo do Journal of Intellectual Capital, acrescenta ainda a obsolescência do Balanced Scorecard frente à velocidade das inovações no século XXI. Seu artigo é tão enfático que levou Kaplan e Norton a elaborarem uma resposta apenas dois números depois, no qual insistem na aprendizagem constante necessária ao sucesso do Balanced Scorecard (KAPLAN; NORTON, 2006), e na criação de um hall da fama com de 15 a 25 empreendimentos de sucesso por ano em seu site, com empresas, ditas inovadoras, usuárias de sistemas baseados no modelo.

A controvérsia sinaliza que realmente não há um consenso sobre o sistema "correto" de avaliação de desempenho, sendo mais provável que haja casos e casos, e que cada sistema de

\footnotetext{
${ }^{15}$ No original: But what were the appropriate measures of the future performance? If financial measures were causing organizations to do wrong things, what measures would prompt them to do the right things? The answer turned out to be obvious: Measure the strategy!
} 
avaliação deve considerar as condicionantes das organizações avaliadas, como o sistema de franquias. Ao longo dos anos, propuseram-se diferentes modelos para o sistema de avaliação de desempenho global. No item 2.7, apresentam-se um resumo dos mais significativos e suas características relevantes.

\subsection{Abordagens prescritivas e modelos de avaliaç̃o}

Não é propósito deste trabalho realizar a revisão de todos os métodos de avaliação de desempenho desenvolvidos. Diferentes autores realizaram levantamentos sobre o assunto, com diferentes enfoques. Giglioni e Bedeian (1974) abordaram o tema do ponto de vista do controle; Corrêa (1986) focou as avaliações que poderiam se aplicar às empresas estatais; Yeniyurt (2003) estudou o Economic value added (EVA), o Balanced Scorecard (Balanced Scorecard ), o Skandia Navigator e a avaliação pelo enfoque do marketing; Neely (2005) realizou um estudo mais profundo, comparando as distinções entre os modelos; e Hourneaux (2005) fez um levantamento mais recente, abrangendo mais de 13 modelos, apontando vantagens e desvantagens do uso geral de cada um. Entretanto, considerando o propósito deste estudo, realizar-se-á um resumo dos principais métodos e de seus enfoques, e nos capítulos seguintes, considerar-se-ão essas abordagens à luz do sistema de franquias.

\subsubsection{Tableau de Bord}

O Tableau de Bord é um sistema baseado na representação, ou modelo da organização como um sistema, e nas relações da organização com seu meio. Esse modelo intui que os gestores precisam acompanhar principalmente fatores críticos, apontados como indicadores-chave para conseguir o adequado monitoramento do desempenho organizacional. Deve-se notar que o modelo já previa a rediscussão constante das escolhas feitas para os indicadores chaves. (LEBAS 1996, pp. 89-90 apud. BAKER; BESSIRE, 2005).

O Tableau de Bord (painel de comando) é considerado o primeiro dos métodos de avaliação de desempenho organizacional. Seu desenvolvimento ocorreu no início do século XX, quando engenheiros franceses de processo preocuparam-se em se aprofundar nas relações de causa e efeito implícitas na produção (EPSTEIN; MANZONI, 1997, p.29). A tradição francesa difere do modelo anglo-saxão de ênfase em desempenho financeiro, provavelmente devido ao menor desenvolvimento da bolsa de valores na França. Engenheiros pensando no negócio em longo 
prazo sinaliza que realmente havia menos pressão por resultados imediatos, situação típica das transações em bolsas (LEBAS, 1994). A idéia básica era que se utilizasse o Tableau de Bord (TdB) na condução do negócio da mesma forma como se utiliza um painel de utilizado para se pilotar um avião ou se operar uma máquina.

De acordo com Bourguignon et al. (2004, p.116) como o sistema é muito antigo, acompanhou a evolução da avaliação de desempenho. De sua criação até aproximadamente os anos 70, sua função era principalmente reportar o que havia ocorrido, por outro lado a ênfase atual é outra e está em como por as coisas em ação.

O Tableau de Bord faz parte dos modelos conhecidos com Dashboards e, segundo Epstein e Manzoni (1997, p.29), apresenta duas características relevantes:

\begin{abstract}
-Não pode ser um documento único aplicado igualmente para toda a firma. Como cada unidade tem diferentes responsabilidades e objetivos, então deve haver um tableau de bord separado para cada uma.

-Os diversos tableau de bord utilizados não devem se limitar a indicadores financeiros. Medidas operacionais tendem a prover melhor informação sobre o impacto de decisões e eventos locais, bem como das relações de causa e efeito. ${ }^{16}$
\end{abstract}

O método encaixa-se em um dashboard mais do que em um scorecard, porque, segundo Hacht, Lawson e Stratton (2007), apresenta características como:

- atualização constante (horas, dias ou semanas) ligada à leitura freqüente de dados;

- disposição das informações na forma de gráficos, com pouca presença de textos;

- alta customização: contém métricas não necessariamente ligadas à estratégia, diferenciandose dos scorecards;

- comparação de resultados e foco no que aconteceu no passado.

A seguir, o modelo estrutural de um tableau de bord, conforme ilustração 1:

\footnotetext{
${ }^{16}$ No original: The Tableau de Bord cannot be a single document applying equally well to the whole firm since each subunit has different responsibilities and goals it should have a separate Tableau de Bord.

The various Tableau de Bord used within the firm should not be limited to financial indicators-operational measures tend to provide better information on the impact of local events and decisions and thus on cause-effect relationships.
} 


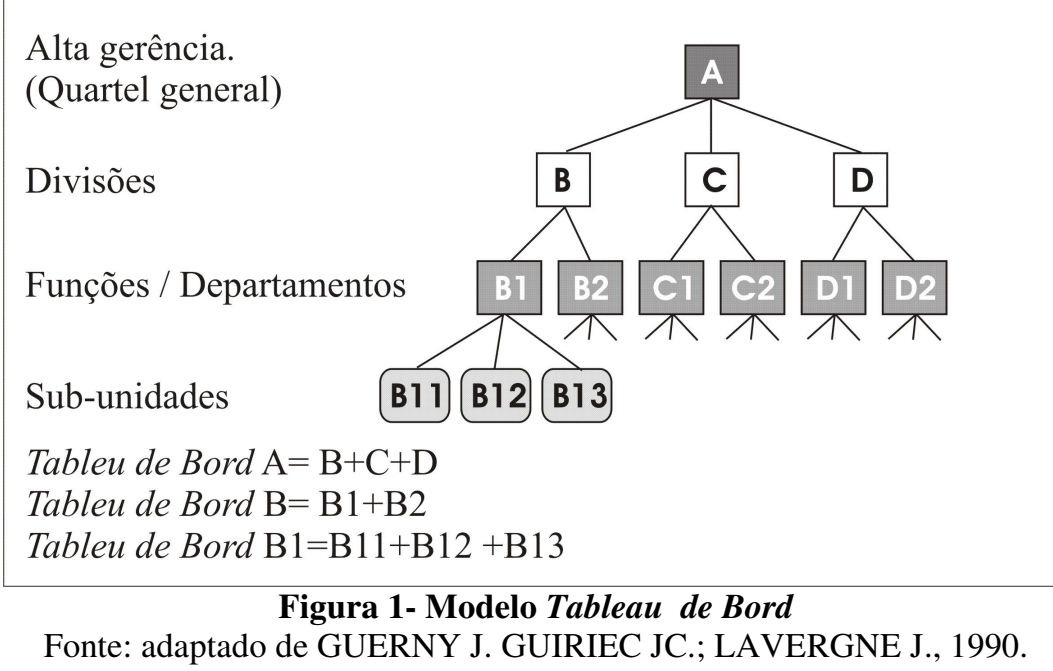

As vantagens decorrentes de seu uso são:

- Fornecer uma visão periódica e resumida de cada unidade para os gerentes das unidades terem suporte no processo de tomada de decisão;

- Informar ao próximo nível superior sobre o desempenho da subunidade;

- Forçar cada unidade a se posicionar no contexto da estratégia da organização e com relação as responsabilidades das outras unidades, e identificar os fatores críticos correspondentes aos indicadores chave de desempenho;

- Contribuir para a estruturação da agenda e direcionar o foco e as discussões administrativas. (EPSTEIN e MANZONI, 1997, p.30) ${ }^{17}$

Segundo alguns autores (HOURNEAUX JR., 2005; HACHT, LAWSON E STRATTON, 2007; BAKER e BESSIRE, 2005), há muitas semelhanças entre o Balanced Scorecard e o Tableau de Bord e muito da propalada inovação daquele já era corriqueira na França. Além disso, em suas conclusões de pesquisa, Hourneaux Jr. defende que muitas vezes as relações de causa e efeito que os Key Sucess Factors procuram encontrar "tem sido particularmente clara em alguns processos, mas de uma grande dificuldade de obtenção em outros." (op. cit, p.107).

Quanto ao uso do TdB, Epstein e Malzoni (1997) apresentam algumas falhas na prática das organizações. Primeiramente, o excesso de indicadores financeiros, em relação ao sugerido pela literatura, ponto reforçado pela pesquisa de Gray e Pesqueux (1993, apud EPSTEIN e MALZONI, 1997). Em segundo, um foco exagerado nos processos internos, inclusive para a

\footnotetext{
${ }^{17}$ No Original:

- Provide each unit manager with a periodic, brief overview of the performance of the unit to guide decision making.

-Inform the next level up of the subunit's performance;

- Force each subunit to position itself within the context of the company's overall strategy and the responsibilities of other subunits and to identify corresponding KSF and KPI;

-Contribute to structuring management's agenda and directing managerial focus and discussions.
} 
elaboração de metas, o que contraria a literatura do $\mathrm{TdB}$, que não chega a propor a atenção ao ambiente externo, mas não o ignora. Outra falha apontada é que o modelo não parte de um modelo estratégico como o de Porter, no qual o Balanced Scorecard apóia-se, mas pressupõe sua construção a partir da definição de cada gerente sobre estratégia, o que pode implicar em maiores dificuldades de utilização (BOURGUINGON et. al., 2004, p.120).

Por outro lado, Bouguingon apresentam uma das maiores vantagens do TdB em comparação com outras abordagens mais recentes:

O Balanced Scorecard é um método da moda sem tradição, mas com uma retórica otimista, que encoraja os administradores propondo 'vá lá fora e faça'(Alvarez, 1998). Aqui, ele difere do Tableau de Bord, que as companhias francesas têm tradição em usar, modificar e desenvolver. Além disso, eles mantêm o conceito em desenvolvimento por pelo menos 50 anos. ${ }^{18}$ (BOURGUINGON et. al., 2004, p.119).

Em administração, certamente o fato de ser antigo não é necessariamente uma vantagem, mas provavelmente sim o de ser longevo.

\subsubsection{Martindell}

A primeira edição de The scientific appraisal of management foi publicada em 1950 pela Harper e Brothers e traz a proposta do então presidente do American Institute of Management, Jackson Martindell, para a realização de uma análise completa das organizações. Nas primeiras 278 páginas de seu livro, o autor exemplifica como avaliar, em uma empresa, um quadro de diretores, como valorar sua atuação financeira, como sua estrutura hierárquica opera, como a localização geográfica de sua planta interfere no sucesso empresarial e somente em um apêndice, nas últimas páginas, o autor apresenta seu modelo. As análises apresentadas por Martindell nas páginas iniciais do seu livro exemplificam muito bem que parte essencial do problema de uma avaliação de desempenho não é obter informações, mas interpretá-las. Por exemplo, ele analisa alguns números financeiros de uma companhia e apresenta uma tendência ao aumento de ativos fixos e diminuição de capital em caixa e suas possíveis conseqüências (MARTINDELL, 1950).

\footnotetext{
${ }^{18}$ No original: the balanced scorecard is a fashionable method without a tradition but with a fairly optimistic rhetoric which encourages managers to "go out and do it" (Alvarez, 1998). In this, it differs from the tableau de bord, which French companies have a tradition for using, changing and developing. Thus, they have kept developing the concept for at least 50 years.
} 
O método de Martindell foi desenvolvido a partir das explanações oferecidas no livro e, segundo o autor, utilizado para avaliar mais de quatrocentas empresas nos EUA.

Ele foi desenhado para indicar quais questões a administração pode responder rapidamente, compreensivamente e sem ambigüidade, e quais não podem ser respondidas desta maneira, assim indicando a extensão dos problemas gerenciais. (Ibid, 1950, p.279). ${ }^{19}$

A metodologia consiste em um grupo de perguntas que uma organização deve responder e , segundo o autor, uma das exigências do método é estabelecer quem deve responder a cada pergunta. Há um total de 301 questões, como as seguintes, que pretendem avaliar o corpo executivo: "284. Quais mudanças ocorreram no corpo de executivos nos últimos 15 anos? 285. Alguma destas mudanças parece ter sido realizada senão por mérito?“ (MARTINDELL, 1950, p.293). ${ }^{20}$

As perguntas objetivam avaliar as diferentes dimensões propostas, num total de dez módulos, apresentados na tabela 3:

Tabela 3 - Pontuação segundo Martindell

\begin{tabular}{|c|c|}
\hline Módulos & Valor máximo possível do Índice \\
\hline Função econômica & 400 \\
\hline Estrutura organizacional & 500 \\
\hline Saúde dos resultados & 600 \\
\hline Justiça para os acionistas & 700 \\
\hline Pesquisa e desenvolvimento & 700 \\
\hline Análise da alta administração (diretoria) & 900 \\
\hline Políticas fiscais & 1100 \\
\hline Eficiência da produção & 1300 \\
\hline Vigor das vendas & 1400 \\
\hline Avaliação dos executivos & 2400 \\
\hline Total & 10.000 \\
\hline
\end{tabular}

Fonte: adaptado de Martindell, op. cit, p.280

Obteve-se parte dos dados no método de Martindell nas perguntas, mas pode-se obter outra em entrevistas com os administradores, coleta de informações e registros históricos. (CORRÊA, 1986, p.36). Não se deve, entretanto aplicar o modelo sem quaisquer alterações,

\footnotetext{
${ }^{19}$ No original: It has been designed to indicate which questions a company's executives can answer readily, comprehensively, and unambiguously, and which questions cannot be so answered, thus indicating the extent of the company's management problem.

${ }^{20}$ No original: 284. What changes have occurred in executive personnel in last fifteen years? 285. Do any of these changes appear to have been made other than on merit?
} 
pois Martindell observa que se devem conformar questões suplementares e o peso atribuído a cada módulo às peculiaridades da indústria.

Os requisitos que a avaliação deve responder, segundo Martindell (1965, apud CORRÊA op. cit, p.35), são:

- ter flexibilidade, permitindo a aplicação a diversos tipos de administração e em todos os campos do conhecimento;

- assegurar a compreensão, na medida em que o analista saberá precisar a pergunta a ser feita para se ter uma visão geral da empresa;

- permitir comparação entre organizações: assim, deve-se fazer as mesmas perguntas, na mesma ordem, de modo a propiciar a comparação entre empresas;

- fornecer medidas de qualidade da administração, refletida nas respostas às perguntas;

- considerar a inter-relação de todas as funções administrativas: uma parte do processo de administração afeta e é afetada por todas as outras.

Hourneaux Jr. (2005) destaca o pioneirismo do método, e Corrêa (1986) aponta o sistema como o primeiro que relaciona todos os módulos em um único índice; aponta ainda a dificuldade para se implantar o método entre seus problemas.

A principal fragilidade do método talvez esteja exatamente nesse número único, que pouco explica, afinal, para uma organização, o que quer dizer ter 8.700 pontos em um ano e, no seguinte, 8.800. Mesmo um número 8.700 constante por três anos, que daria a um gestor uma noção de estabilidade, pode mascarar grandes flutuações nos indicadores dos módulos, já que apenas a soma mostra-se constante.

Além disso, as perguntas elaboradas por Martindell, muitas vezes pouco revelam sobre a corporação, por exemplo: “155. Qual a remuneração da diretoria?”21, “156. Onde a diretoria mora?" (1950). Neste caso, fica também a dúvida sobre como pontuar essas respostas. Outras perguntas são mais significativas, mas apresentam profundas dificuldades para se responderem, como: "141. Em que extensão a divisão de pesquisa coopera com outros na mesma ou em indústrias relacionadas?" 22 (op. cit.), e ainda uma pergunta aparentemente irônica: "Há relatórios em excesso?" 23 (op. cit.).

\footnotetext{
${ }^{21}$ No original: 155. What is a director's remuneration? Expenses?

156. Where does each live?

${ }^{22}$ No original: 141 . To what extent does the company's research division cooperate with others in the same or related industries?

${ }^{23}$ No original: $\quad 110$. Are too many operating reports issued?
} 
Conclui-se, portanto que o método realmente não é de simples implantação, e passados mais de meio século de sua criação, soa estranho aos administradores da atualidade.

\subsubsection{Administração por objetivos - Drucker}

Em 1954, Peter Drucker publicou o livro The Practice of Management, que disseminou entre os gestores a Administração por Objetivos (APO). Seus conceitos foram aprofundados por George Odiorne, em sua obra de 1965, Management by Objectives, que deu maior enfoque ao uso de medidas quantitativas. Segundo Maximiano (2004), o trabalho de Drucker é uma evolução dos princípios de Alfred Sloan aplicados na General Motors.

Segundo Neely (2005), Peter Drucker foi o primeiro autor a considerar as idéias de Argyris sobre o impacto dos processos de avaliação com o desejo de medir das organizações, e propor como resposta a utilização de medidas balanceadas. O autor argumenta ainda que: "Se o relógio for adiantado trinta anos, nós vamos descobrir que os mesmos temas permanecem em discussão." ${ }^{, 4}$ (op. cit.,p.1265)

Drucker esclarece quais objetivos devem-se perseguir: "Objetivos são necessários em todas as áreas cujos resultados e desempenho afetem de maneira direta e vital a sobrevivência e prosperidade da empresa". (1981, p.60)

A APO é uma abordagem que procura resolver as diferentes percepções dos objetivos e metas pelos membros das organizações. Todas as administrações possuem objetivos e metas, portanto todos os gerentes devem também alcançar objetivos e metas, mas quando estas não se estabelecem de modo claro, podem ocorrer mal-entendidos sobre quais são (Silva 2001, p.432-433).

De acordo com Chiavenato, "a APO é um processo pelo qual os gerentes e subordinados identificam objetivos comuns, definem as áreas de responsabilidade de cada um em termos de resultados esperados e utilizam esses objetivos como guias para suas atividades.”( 2003, p.288). Os resultados esperados serão nesse método considerados os indicadores ou padrões alvos, e serão comparados aos resultados efetivos alcançados pelos subordinados.

\footnotetext{
${ }^{24}$ No original: If the clock is turned forward thirty years then we find that the same themes are still being discussed.
} 
O APO enfatiza resultados e não personalidades ou desculpas. A fase de controle está completa quando o sucesso do processo é recompensado com promoções, prêmios de mérito, ou outros benefícios convenientes, e quando a falha é observada para futura ação corretiva. (SILVA, op. cit., p.434)

As quatro etapas do processo de APO são listadas por diferentes autores, como Drucker (1981), Chiavenato (op. cit), Daft e Marcic (2004 p.154, apud Hourneaux, op. cit, p.41), Palmer e Dinesh, e Silva (2001):

1 - estabelecimento de metas e objetivos, por escrito. (Drucker cita a necessidade de se estabelecer a estratégia organizacional antes dessa etapa).

2 - desenvolvimento de plano de ação.

3 - revisão periódica.

4 - avaliação de desempenho na base previsto versus realizado.

A figura 2 sintetiza o processo.

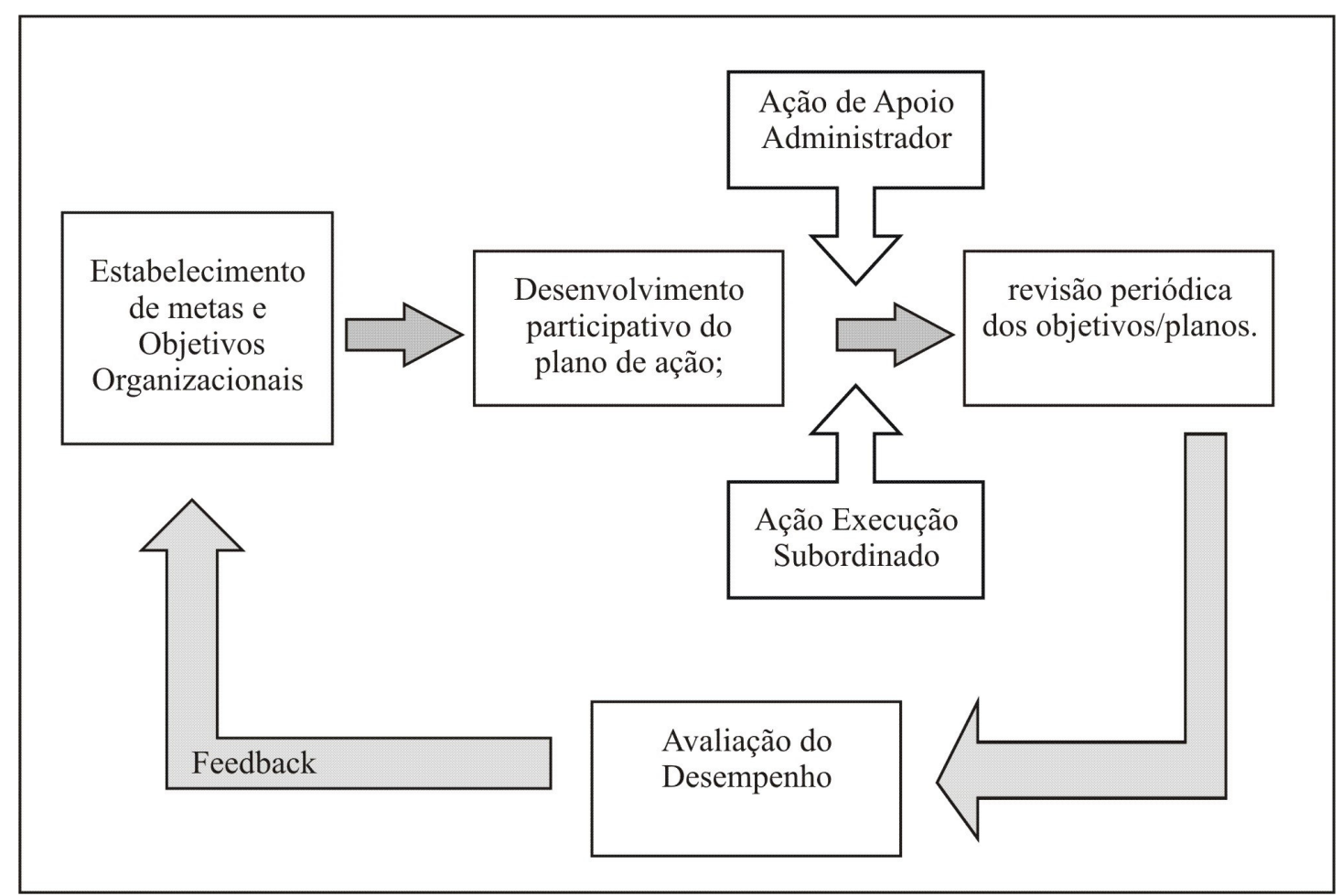

Figura 2 - O processo APO

Fonte: adaptado de SILVA, 2001, p.434. 
Considera-se o processo participativo, pois a definição das metas e objetivos, ao menos na prática atual do modelo pelas empresas, é realizada pelo conjunto administrador e subordinado.

Drucker (1981, p.326) informa que o processo de avaliação de desempenho dá-se a partir do estabelecimento de escalas de mensuração, focados nos poucos fatores principais para a avaliação de desempenho, da organização e dos colaboradores. "Objetivos, metas e alvos servem para determinar quais medidas devem ser tomadas hoje para se obter resultados amanha" (ibid, p.83).

Algumas críticas foram feitas a APO, como os possíveis conflitos entre os objetivos individuais e os objetivos organizacionais, e o risco do sistema tornar-se um simples instrumento de pressão sobre os subordinados. (SILVA, op. cit, p.463).

Outra crítica relevante é a dificuldade de se transmitirem objetivos entre os diferentes níveis organizacionais: "[...] a administração por objetivos pode complicar-se porque o que aparenta ser um objetivo simples em um nível ou uma função da organização, pode ser considerado uma caixa preta de objetivos inter relacionados ou opostos em outro nível ou em outro departamento." ${ }^{25}$ (DAHLSTEN et al, 2005, p.535). Apresentou-se essa crítica junto com um estudo de caso realizado na empresa Volvo, exemplificado como um objetivo claro: "vender 600 mil carros por ano" era compreendido de forma diferente entre os diversos níveis e departamentos: alguns compreendiam a mensagem como uma visão, outros como um objetivo real a se perseguir, e outros, ainda, apenas como uma frase significando "precisamos vender mais". As implicações do objetivo eram ainda mais confusas. Certamente aumentar o volume vendido correlaciona-se a satisfazer os clientes e a reduzir os preços, portanto os custos de produção, mas essas relações não estavam claras para boa parte dos gerentes de nível médio. Havia ainda dúvida sobre qual era a prioridade, por exemplo: reduzir custos ou satisfazer os clientes? Em resumo, os gerentes não traduziam o volume de vendas em processos e ações, agindo cinicamente sobre o método. (ibid.).

\footnotetext{
${ }^{25}$ No original: $M B O$ may be complicated because what appear to be an uncomplicated objective at one level or in one function of the organization may be regarded as a black box of interrelated or opposing objectives at another level or in another department.
} 
Chiavenato (op.cit, p.247) elenca três aspectos que colaboraram para um descrédito do APO: primeiro o excesso de papelório, ou a tendência de burocratizar o método nas grandes organizações; o seu caráter autocrático e impositório; e a motivação negativa gerada pelos objetivos impostos. O autor cita que empresas bem sucedidas na prática do APO aplicam intensamente a participação dos subordinados nos processos, a freqüência de interação e revisão e o foco nos objetivos, porém afirma que ainda há muitas empresas que utilizam o APO, da mesma forma como afirmam Dahlstein et. al. (op. cit) e Silva (op. cit), entre outros. Pesquisa realizada com empresas públicas nos EUA mostraram que, ao menos para esses casos, o uso não ocorre em toda a organização, mas apenas em alguns departamentos e funções (78\% dos casos). (Dinesh D.; Palmer E., 1988, p.366)

\subsubsection{Corrêa}

Em 1986, Hamilton L. Corrêa, estudou os modelos existentes e propôs um para a avaliação de empresas estatais brasileiras. Seu trabalho foi publicado em tese de doutoramento com o título: “O 'estado da arte’ da avaliação de empresas estatais", na qual se consideraram, devido à especificidade do tema, alguns aspectos geralmente não discutidos, como a conjuntura política, ou a necessidade de dar relevância ao usuário do bem ou serviço público. O autor acredita que nas empresas estatais, antes de se desenvolver um sistema de avaliação de desempenho, é necessário um trabalho prévio. "É importante a elaboração de um plano empresarial, seu respectivo sistema de informação e sua efetiva implantação na empresa" (CORRÊA, 1986, p.186). Além disso, destaca que ao avaliar uma empresa estatal, procede-se à avaliação de um agente do governo, portanto os critérios não podem ser os mesmos dos empregados na empresa privada. Também chama a atenção para um ponto pouco comentado nos modelos, questionando quem faz a avaliação.

A metodologia de Corrêa (op. cit, p.198-204) baseia-se nas seguintes etapas:

1 - Descrição da empresa, objetivos e missões.

2 - Definição dos módulos ou áreas em que se dividem as empresas para efeito de avaliação. Os módulos formam-se por um conjunto de indicadores e devem-se ajustar conforme as especificidades, podendo haver inclusão ou exclusão no grupo sugerido. A lista, a seguir, contempla a proposta do autor:

- Econômico financeiro; 


\section{- Operacional;}

- Recursos humanos;

- Satisfação do usuário/cliente;

- Inovação tecnológica;

- Adaptação ao ambiente presente e futuro;

- Avaliação técnica (qualidade da tecnologia empregada);

- Clima organizacional;

- Benefícios sociais

- Potencialidade gerencial.

Após a definição dos módulos, o autor propõe sua hierarquização em ordem de importância em relação aos objetivos da empresa, e a verificação das relações entre os módulos. Em seguida,definirem-se os indicadores em cada módulo.

A definição dos indicadores, em si, não diz muito caso não exista um alvo ou um grupo para comparação. O autor estabelece, após a definição dos indicadores, um levantamento com outras empresas nacionais ou dados internacionais com a finalidade de auxiliar essa etapa, pois apenas então será possível definir padrões idéias. Neste ponto, há uma restrição à aplicação da metodologia, visto que, muitas vezes, não se podem obter esses números.

Finalmente Corrêa (op. cit, p.203) propõe que a avaliação e feedback ocorram pela comparação entre os padrões. Por último, segue o procedimento de Martindell, sugerindo uma atribuição de pesos para cada um dos módulos, a fim de avaliar globalmente a empresa pela soma dos seus resultados individuais.

Corrêa apresenta uma limitação de sua metodologia, ao argüir que um número obtido ao final do processo pouco informa. "Caso esta empresa chegue a 700 pontos, o que significa esse número? Um bom desempenho, um desempenho regular?” (1986, p.206). Para ele, esse número apenas faz sentido quando outras empresas adotam metodologia semelhante, ou quando há um histórico de, ao menos, três anos.

A última proposição de Corrêa considera se há sentido em comparar o desempenho de empresas que utilizam o mesmo modelo de avaliação, quando este apresenta alguma customização, como todas as metodologias até aqui apresentadas. Um gestor utilizar uma 
avaliação de desempenho com o objetivo de analisar sua organização e ajustar o caminho da mesma é diferente de uma sociedade avaliar as suas organizações e seu retorno social. Se cada empresa utiliza um grupo de indicadores, é possível compará-los?

A metodologia de Corrêa acrescenta ao debate a ênfase no retorno social, que hoje preocupa também empresas privadas, na esfera da responsabilidade social. Deve-se considerar esse aspecto no caso do franchising, já que as discussões de responsabilidade social vinculam-se profundamente às discussões de valor de marca, o principal ativo das empresas franqueadoras. $^{26}$

\subsubsection{Balanced Scorecard}

Conforme citado, o Balanced Scorecard (BSC) foi desenvolvido pelos professores de Harvard, Kaplan e Norton. Em janeiro de 1992, o artigo "The Balanced Scorecard-measures that drive performance" já resumia os pontos-chave dos autores e se baseava em pesquisa conduzida junto com a KPMG. Após esse artigo, diversas empresas procuraram os autores para implantar o BSC dessa experiência, saiu o livro The Balanced Scorecard, no Brasil traduzido por “A Estratégia em Ação: Balanced Scorecard” (Kaplan e Norton, 1997). O novo enfoque apresentado pelos autores, além do momento de ampliação do uso de computadores que facilitavam a coleta de dados, entre outros fatores, ampliou o interesse pelo uso do BSC pelas organizações. Segundo os autores, entre 1992 até 2000, apenas eles trabalharam em mais de 200 organizações na adaptação e uso do BSC (ibid. 2001, p.10). O modelo do BSC apresenta algumas características já existentes em alguns dos modelos abordados, mas com menor enfoque.

A primeira dessas características é o "enfoque estratégico". O BSC tem como um dos pilares fundamentais a idéia de funcionar como uma ferramenta de comunicação da estratégia para os diversos níveis organizacionais, além de também utilizar a avaliação de desempenho e o alinhamento estratégico, ou foco. (Kaplan e Norton, 2001, p.7).

A aplicação do Balanced Scorecard inicia-se, portanto, com a definição estratégica. A organização deve ter uma estratégia clara, descrita como mapas estratégicos, posteriormente

\footnotetext{
${ }^{26}$ Essa discussão está desenvolvida nas conclusões da revisão bibliográfica.
} 
traduzida para termos operacionais. Em seguida, deve haver a comunicação da estratégia para todos da organização. Os autores resumem os passos seguintes nos itens abaixo (ibid, 1997, p.304-305):

\footnotetext{
- Alinhamento das metas de departamentos e indivíduos à estratégia;

- Identificação e alinhamento das iniciativas estratégicas;

- Associação dos objetivos com as metas de longo prazo e os orçamentos anuais;

- Alinhamento das revisões estratégicas e operacionais.

- Obtenção de feedback para fins de conhecimento e aperfeiçoamento da estratégia.
}

Antes dessas, etapas a aplicação do modelo deve ter um responsável, normalmente um alto executivo, que atuará como líder de projeto e terá acesso a alta administração. (ibid. 1997, p.313). O Balanced Scorecard propõe quatro módulos para análise da organização, e aceita que esta adicione outro módulo adicional, caso sinta a necessidade, para cada um desses módulos, a fim de definir objetivos, indicadores, metas e iniciativas.

Em sua obra (1996), os autores listam e descrevem detalhadamente as quatro perspectivas que se devem contemplar na elaboração de um BSC. As perspectivas ou módulos são:

- Financeira, ou seja, a estratégia para a lucratividade, o crescimento e a visão de risco pelos acionistas;

- Do cliente, ou seja, a estratégia para criação de valor ao cliente;

- Dos processos internos, ou seja, as prioridades estratégicas para os processos do negócio;

- De aprendizagem e crescimento, ou seja, as prioridades para a construção de um clima de inovação, mudança e crescimento. 


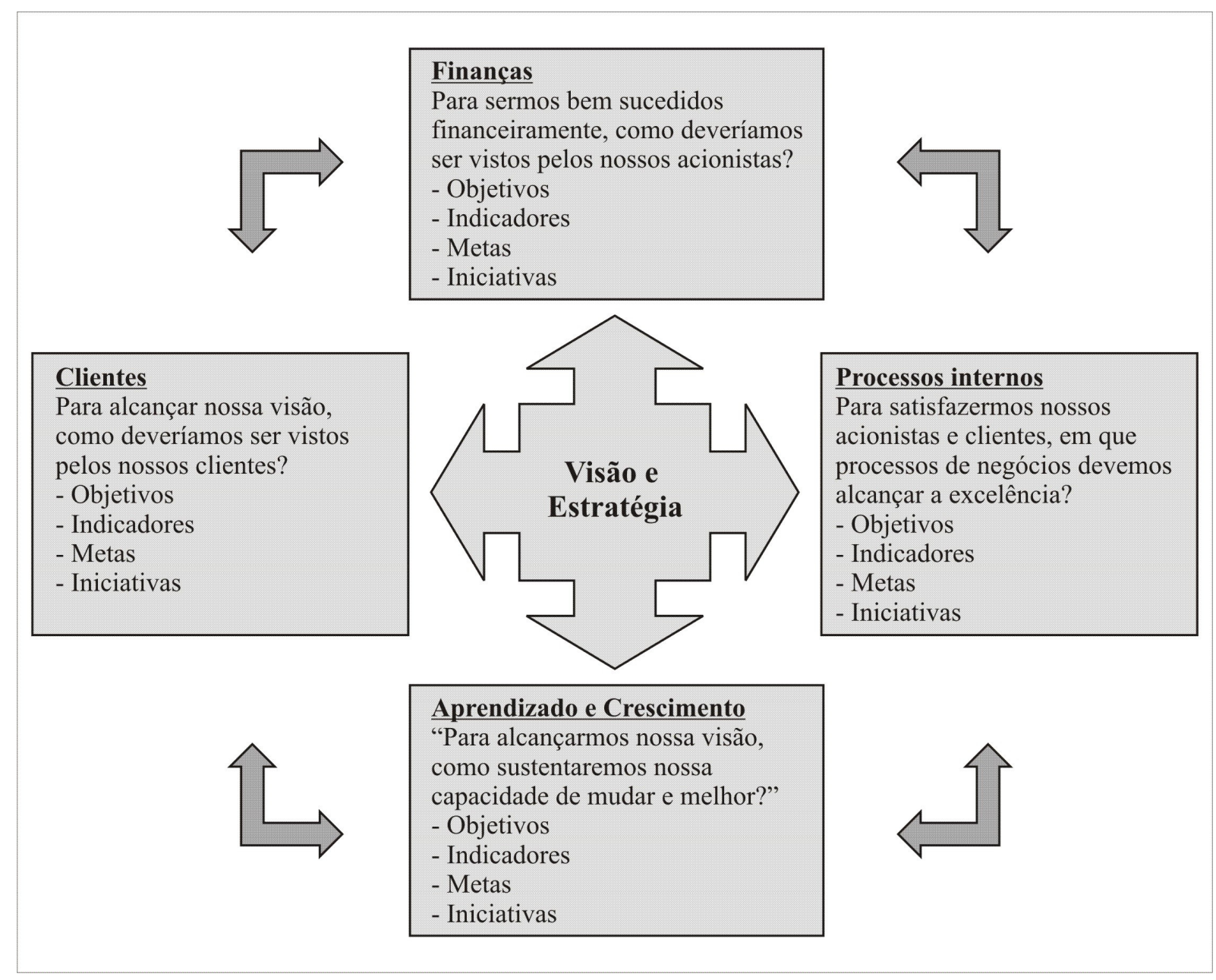

Figura 3 - Modelo Balanced Scorecard

Fonte: adaptado de KAPLAN e NORTON, 1997, p.10

Os indicadores não financeiros são uma redescoberta do Balanced Scorecard, pois já eram presentes em diversos modelos anteriores; ainda assim, sua presença e ênfase nessa característica foi fundamental para o sucesso do modelo e sua aceitação pelas empresas.

Há várias vantagens para as organizações utilizarem o Balanced Scorecard: uma das mais nítidas é a possibilidade de agregar quatro perspectivas em um único documento simplificado (EPSTEIN e MANZONI, 1997, p.32). Segundo esses autores, diversas empresas verificam diferentes perspectivas, contudo, ao contrário do que ocorre no Balanced Scorecard, nestas as perspectivas apresentam-se em uma quantidade vasta de documentos, com informação em excesso, atrapalhando a análise.

A presença do Balanced Scorecard não elimina a necessidade dos administradores explicarem o que esperam obter e porque, mas reforça essa comunicação. (EPSTEIN e MANZONI, op. 
cit, p.33). Por outro lado, as perguntas "Até que ponto um processo eficaz de formação de estratégia deve ser deliberado ou emergente? Até que ponto existe a necessidade de controle a priori em oposição a um aprendizado a posteriori?" (MINTZBERG et al, 2000, p.267) parece intensificar-se na presença de um modelo que, mais do que avaliar, procura disseminar uma estratégia.

Há também desvantagens em utilizá-lo. O Balanced Scorecard é, em certo sentido, mais rígido que outras metodologias altamente customizáveis, como o Tableau de Bord. Epstein e Manzoni (op. cit) apontam que isso se deve a estrutura proposta por Kaplan e Norton, que direciona quatro perspectivas, enquanto o Tableau de Bord, por exemplo, não explicita quais as perspectivas que se devem considerar. Os autores, por outro lado, indicam que essa rigidez não se reflete sobre a escolha dos indicadores, sendo muito mais um guia e uma forma de sinalizar os principais ângulos considerados por qualquer empresa. Kaplan e Norton (1997) inclusive argumentam que as quatro perspectivas podem-se acrescer de outras, caso necessário para a situação daquela organização. Ainda assim, pode-se argüir, como informado nos argumentos iniciais desse estudo, que todas as escolhas condicionam um olhar sobre a realidade, logo há certa razão nos que pregam essa fragilidade do BSC.

Entretanto, os outros métodos até aqui apresentados também condicionam a leitura, em maior ou menor grau. As criticas de Graham Kenny (2003), consultor australiano freqüentemente procurado por gerentes que não conseguiam aplicar o modelo, exemplificam os problemas práticos. Num dos casos, um gestor de um hospital não conseguia aplicar as perspectivas e fazia às seguintes perguntas: "Onde entra a perspectiva dos estudantes? Eles são clientes? E os fornecedores? E a dos empregados?" Volpel et. al. (2006) argumentam que o BSC amarra a organização e dificulta a aprendizagem, mesmo contemplando essa perspectiva em seu modelo.

Hourneaux, Cunha e Corrêa, (2004) estudaram a aplicação do BSC no Banco Bradesco, e verificaram algumas ressalvas quanto à aplicação do modelo em áreas como inovação. 
Hatch, Lawson e Stratton (2007) defendem que o BSC é uma ferramenta de médio prazo, e deve-se utilizá-la com outros instrumentos, como os painéis de comando ${ }^{27}$, dada a capacidade dos últimos de diagnósticos no curto prazo.

\subsubsection{Skandia Navigator}

A discussão sobre capital inicial remonta a 1986, com as discussões de Karl Sveiby sobre ativos intangíveis, no artigo Know-How Company, e evoluiu dentro da área de gestão do conhecimento. A empresa sueca Skandia AFS oferece serviços financeiros e na área de seguros. Desde 1994, iniciou um processo de publicação de informações sobre capital intelectual, além dos tradicionais resultados financeiros, o qual processo culminou com o estabelecimento por Leif Edvinsson, diretor da empresa, de parâmetros para discutir o capital intelectual e os ativos intangíveis das empresas (MOURITSEN, et. al., p.399 2001). "A maioria dos pesquisadores concorda que os esforços da Skandia para criar uma taxonomia de medidas para os ativos intangíveis das companhias estimularam outros a olhar além das premissas habituais sobre criação de valor para os acionistas.” (BONTIS, 2001, p.41).

Segundo Edvinsson (1997, p.366), os argumentos que fundamentaram as propostas da Skandia baseavam-se na idéia de que a compra de uma empresa não deve avaliar apenas seus ativos físicos. "O que medir? O número de consumidores? [...] Como avaliar o número de boas idéias?". A Skandia buscava responder a necessidade de uma avaliação mais integrada e balanceada. Muitos desses aspectos são considerados senso comum, sendo mais importante, segundo o autor, a colaboração da empresa ao pôr essas idéias em prática.

Primeiramente, a administração da empresa esforçou-se para identificar os aspectos visíveis e mensuráveis dos ativos intangíveis. "A lista de itens de valor, que tradicionalmente não constam de balanços e análises financeiras, consistia de marcas, concessões, bases de clientes, sistemas de tecnologia, competências, parceiros e alianças, pessoas chave, e outros 50 itens." (ibid, p.368). Toda essa lista indica aspectos do capital intelectual que, em resumo, é aquilo que o sistema propõe-se avaliar. O capital intelectual é a soma do capital humano e do capital estrutural de uma empresa, e representa aquilo que trará resultados financeiros no futuro.

\footnotetext{
${ }^{27}$ No original: dashboard
} 
A ilustração 4 sumariza o modelo do Skandia Navigator. O balanço entre passado, representado nos resultados econômicos obtidos, presente, contemplado pelos processos e recursos humanos atuais, e o futuro, visível através da renovação e desenvolvimento, é evidenciado no modelo. O modelo também considera o ambiente externo.

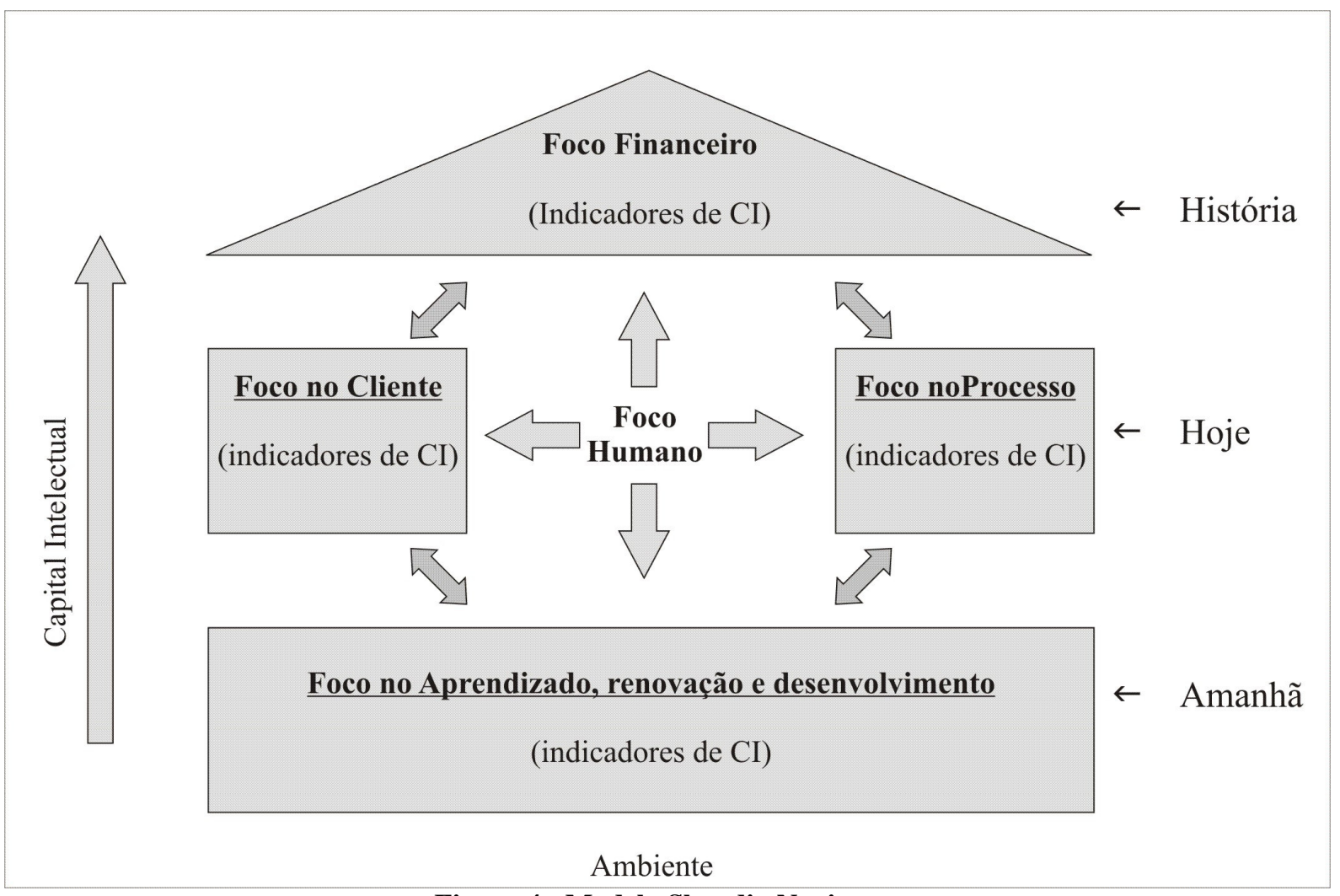

Figura 4 - Modelo Skandia Navigator

Fonte: adaptado de EDVINSSON, 1997, p.371

A construção dos indicadores, por outro lado, assemelha-se as propostas vistas nos modelos anteriores. Partindo da missão, core business, e objetivos, desenham-se os fatores críticos de sucesso, traduzidos em informações para a elaboração dos indicadores.

Segundo Barsky e Bremser (1999, p.9) “os processos principais do negócio são classificados em cinco categorias, no Skandia Navigator: foco financeiro, foco no cliente, foco no processo, foco na renovação e desenvolvimento, e foco no humano." ${ }^{28}$. Além disso, os autores acrescentam que os relatórios internos e externos baseiam-se nesse método.

\footnotetext{
${ }^{28}$ No original: The Business Navigator classifies core business processes into five categories: (1) Financial Focus (2) Customer Focus (3) Process Focus (4) Renewal and Development Focus (5) Human Focus.
} 
Edvinsson (op. cit., p.371) sugere ainda que possa haver no sistema um modelo de recompensas, mas não detalhe seu funcionamento.

\subsection{Comentários sobre os modelos.}

Testou-se esse repertório de modelos na prática em diferentes empresas e organizações; em certos casos, obtiveram-se bons resultados para as organizações, enquanto em outros, fracassos $^{29}$. Entretanto, realizaram-se poucos estudos conclusivos sobre cada um dos modelos, visto ser muito complexo atribuir ao modelo o sucesso ou fracasso de uma estratégia, bem como isolar os efeitos do uso de um modelo dos efeitos do conjunto das práticas organizacionais. Em parte, devido a essas razões, como já apontara Corrêa, "a metodologia de avaliação de empresas tem apresentado poucos avanços, tanto no campo conceitual como no desenvolvimento de metodologias operacionais." (1986, p.187).

Além disso, há interesses econômicos no sucesso de um modelo em detrimento de outros, dado que grandes corporações aplicam os mesmos e muitas vezes contratam seus autores para auxiliá-las, o que cria um potencial viés nas pesquisas. Exemplificando, os professores Kaplan e Norton dirigem uma consultoria, a Balanced Scorecard Collaborative, em que auxiliam corporações e governos, e listam clientes, como o National City Bank, o Peoples Bank, a Astra Zeneca , Blue Cross Blue Shield e as forças armadas americanas ${ }^{30}$. Para eles, o modelo continua se desenvolvendo enquanto prestam consultorias às empresas que buscam utilizá-lo. É interessante notar, por exemplo, que os autores formados em Harvard, como Epstein e Malzoni (1997), elogiam o modelo americano do Balanced Scorecard e criticam o modelo francês do Tableau de Bord. Por outro lado, Lebas (1994), professor na França, elogia o TdB e critica o BSC . Voelpel et. al. (2006), pesquisadores da Alemanha criticam o BSC, enquanto Kaplan e Norton (2006), autores do modelo, defendem-no ferozmente. Esse é um problema típico da pesquisa em administração, mas não é o único viés possível. Na realidade, ao se considerar qualquer uma dessas abordagens prescritivas, deve-se ter algumas limitações e alguns outros viesses.

\footnotetext{
${ }^{29}$ Fracasso no sentido de abandono do modelo devido a consequiências diferentes das pretendidas.

30 No original: US Army. Essas informações encontram-se disponíveis no endereço da web: http://www.bscol.com/services/training/clients/ . Acesso em 13 de outubro de 2007.
} 
Herbert Simon elaborou estudos, desde 1947, que popularizaram a noção de que o mundo é grande e complexo, em comparação às limitadas capacidades da mente humana. Dessa forma, o processo de tomada de decisão é muito menos racional do que até então se supunha. Às observações elaboradas por Simon (1997), sobre a racionalidade limitadas dos agentes, seguiram-se diferentes estudos mostrando que, muitas vezes, uma escolha racional baseia-se em preconceitos e prejulgamentos. Em algumas situações, obter mais informações, uma das idéias fundamentais em avaliação de desempenho, não ajuda as pessoas no processo de tomada de decisão; ao contrário, apenas reforça preconceitos e linhas de ação que já esperavam adotar, pois "as informações são redundantes e provêm pouco valor adicional" (MAKRIDASKIS apud. MINTZBERG et. al. 2006). No quadro a seguir, sintetizam-se diversas constatações dos pesquisadores da área de cognição, sobre o processo de tomada de decisão: 
Tabela 4 - Evidências de fatores não racionais no processo decisório.

\begin{tabular}{|c|c|}
\hline Tipo de Evidência & Descrição da tendência \\
\hline I - Busca da evidência de suporte & $\begin{array}{l}\text { Disposição para colher fatos que conduzem a } \\
\text { certas conclusões e desprezar outros fatos que as } \\
\text { ameaçam. }\end{array}$ \\
\hline II - Inconsistência & $\begin{array}{l}\text { Incapacidade para aplicar os mesmos critérios de } \\
\text { decisão em situações semelhantes. }\end{array}$ \\
\hline III - Conservadorismo & $\begin{array}{l}\text { Incapacidade para mudar (ou mudar lentamente) } \\
\text { a opinião à luz de novas informações e/ ou } \\
\text { evidências. }\end{array}$ \\
\hline IV - Recentidade (sic) & $\begin{array}{l}\text { Os eventos mais recentes dominam os menos } \\
\text { recentes, que recebem menos importância ou são } \\
\text { ignorados. }\end{array}$ \\
\hline V - Disponibilidade & $\begin{array}{l}\text { Basear-se em eventos específicos facilmente } \\
\text { lembrados, excluindo-se outras informações } \\
\text { pertinentes. }\end{array}$ \\
\hline VI - Ancoragem & $\begin{array}{l}\text { As previsões são indevidamente influenciadas } \\
\text { por informações iniciais que recebem mais peso } \\
\text { no processo de previsão. }\end{array}$ \\
\hline VII - Correlações ilusórias & $\begin{array}{l}\text { A crença de que os padrões são evidentes e/ou } \\
\text { duas variáveis estão relacionadas por causalidade } \\
\text { quando não estão. }\end{array}$ \\
\hline VIII - Percepção seletiva & $\begin{array}{l}\text { As pessoas tendem a ver problemas em termos de } \\
\text { sua experiência anterior. }\end{array}$ \\
\hline IX - Efeitos de regressão & $\begin{array}{l}\text { Aumentos persistentes (em algum fenômeno) } \\
\text { podem dever-se a razões aleatórias, as quais } \\
\text { sejam verdadeiras, iriam elevar a probabilidade } \\
\text { de um decréscimo subseqüente. Por outro lado, } \\
\text { decréscimos persistentes podem elevar as } \\
\text { probabilidades de aumentos subseqüentes. }\end{array}$ \\
\hline $\mathrm{X}$ - Atribuição de sucesso e fracasso & $\begin{array}{l}\text { O sucesso é atribuído às aptidões da pessoa e o } \\
\text { fracasso à má sorte ou ao erro de outra. Isso inibe } \\
\text { o aprendizado, pois não permite o } \\
\text { reconhecimento dos próprios erros. }\end{array}$ \\
\hline XI - Otimismo injustificado & $\begin{array}{l}\text { As preferências das pessoas por futuros } \\
\text { resultados afetam suas previsões a respeito dos } \\
\text { mesmos }\end{array}$ \\
\hline XII - Subestimar a incerteza & $\begin{array}{l}\text { Otimismo em excesso, correlação ilusória e a } \\
\text { necessidade de reduzir a ansiedade resultam em } \\
\text { subestimar a incerteza futura. }\end{array}$ \\
\hline
\end{tabular}

Fonte: MAKRIDAKIS 1990 p.36-37 apud. MINTZBERG et. al. op. cit, p.118

O quadro apresenta doze aspectos que podem introduzir viesses numa avaliação de desempenho global, e em especial, na análise do desempenho e da estratégia adotada. Por exemplo, a busca da evidência de suporte pode influenciar a elaboração de indicadores, bem como sua análise, ou também a atribuição de sucesso e fracasso pode dificultar processos baseados na auto-avaliação. Outro exemplo, o otimismo exagerado, ou seja, um grupo de gestores que tem em comum as expectativas de sucesso da organização pode conduzir uma 
organização para um cenário totalmente inesperado, com uma estratégia inadequada, mas que estranhamente pareceu ótima para todos quando elaborada. Esses processos certamente ocorrem no mundo dos negócios, bastando, para exemplificá-los, citar a entrada da indústria automobilística japonesa no mercado americano e os processos da escola japonesa da qualidade total. As idéias de Deming só permitiram o sucesso da indústria japonesa no mercado norte-americano porque os norte-americanos partiam de um pressuposto inicial errado, que opunha qualidade e custo (MAXIMIANO, 2002).

Entretanto, não é porque existem tais obstáculos, que as empresas não devam avaliar suas estratégias e não se preocupar com a avaliação de desempenho. Se fosse dessa forma, qualquer esforço de racionalização seria inútil e, conforme a teoria de Simon (1994), não é que não haja racionalidade na estratégia, mas apenas que ela tem limites e está sujeita a viesses. Além disso, a própria elaboração da estratégia não é em si um campo fechado. Mintzberg, Ahlstrand e Lampel (2000, p.265-270) listam aspectos não resolvidos sobre estratégia organizacional que podem ser considerados ao se formular uma estratégia. Essas perguntas dimensionam a complexidade do tema:

- Até que ponto as estratégias devem ser elaboradas e complexas?

- Quanta integração é desejável? Quando e onde?

- Até que ponto uma boa estratégia deve ser única ou nova?

- Até que ponto um processo deve ser centralizado e deliberado, ao invés de emergente?

- Quem é o estrategista? É um processo pessoal? Coletivo? Técnico?

- Com relação a mudanças: Como se adaptar e manter ordem e processos em um ambiente instável? Como aprender? Como inovar e de onde vem o novo?

- Quanta opção estratégica existe lá fora?

Após essas considerações, resta proceder com a análise dos diversos modelos apresentados, a qual revela alguns pontos significativos:

1 - Clareza da estratégia, ou ao menos dos objetivos, é pressuposto dos diversos modelos. Se não há uma estratégia clara, não há como avaliar se a organização caminha na direção correta; 2 - Simplicidade ao apresentar as informações e resultados também parece uma das premissas básicas dos modelos. Considerando a facilidade crescente com que se obtêm dados atualmente, devido à computação, esse ponto torna-se essencial; 
3 - Aponta-se a mensuração de aspectos não financeiros, mesmo que superficialmente, em quase todos os modelos, ainda que falhem em definir como conseguir essas medidas. Entretanto, ainda há muito destaque para os indicadores financeiros;

4 - A avaliação de desempenho certamente é útil às organizações, visto que permanece sendo utilizada, mesmo que com modificações, há quase um século;

5 - A flexibilidade é um ponto importante para os diversos modelos, e os autores, de modo geral, sublinham a necessidade de adaptação do modelo ao caso;

6 - Há, nos modelos mais recentes, uma preocupação com os clientes e com a criação de valor ao usuário, sinalizando uma tendência;

7 - A responsabilidade social começa também a aparecer nesse debate, e as dificuldades de avaliar resultados nessa área são especialmente significativas;

8 - Em resumo, há uma preocupação crescente com os stakeholders;

9 - Os modelos não discutem aquilo já consolidado. Espera-se que em uma organização atuante por anos já exista um método de avaliação utilizado, mas nenhum dos autores discute as vantagens ou dificuldades de se apropriar dessa estrutura e cultura prévia, caso proposto um novo modelo.

Além desses pontos, percebe-se também aspectos frágeis nos modelos:

1 - O enfoque histórico, baseado em eventos passados, é visível em diversos modelos e passível de crítica;

2 - Corrêa (1986) enfatiza a dificuldade do enfoque global da avaliação. Corrobora sua afirmação o fato de que os diversos modelos apresentam uma tendência à análise em módulos e sua fragmentação, e não a uma avaliação sintética da organização;

3 - Alguns autores preocupam-se com a eficácia de medir alguns eventos. Para Buchele, mais do que auxiliar, muitas vezes o administrador atrapalha-se devido à mensuração quantitativa (1971, p.143), porém a ênfase continua nos sistemas de avaliação quantitativos, e não nas avaliações sistêmicas ou análises qualitativas;

4 - Boa parte dos modelos, como o Balanced Scorecard ou o Tableu de board, por exemplo, defendem que parte do sucesso de um sistema de avaliação está nas relações de causa e efeito entre às variáveis analisadas, entretanto provar relações causais não é uma tarefa simples.

5 - Algumas vezes, os sistemas de avaliação têm pouco ou mesmo nenhum respaldo teórico, sendo executados por interesses comerciais, através de adaptações que ignoram os fundamentos dos modelos. "Há muita literatura lá fora, de diferentes vendedores de software e 
empresas de consultoria, que definem seus métodos e produtos, mas com definições inconsistentes, levando a confusão"31. (Lawson et. al, 2006, p.33).

6 - Finalmente, a necessidade de se colocarem as informações em números, gráficos e tabelas, talvez não seja mais do que a vitória da tecnocracia, apontada por MINTZBERG. Talvez seja uma decorrência da necessidade humana de acreditar que há poucos riscos.

Os tecnocratas têm uma maneira de nos fazer sentir seguros. Com suas respostas imediatas, seus diagramas e seus gráficos, eles nos fazem sentir que tudo ficará bem, desde que sigamos as regras: as regras da lógica, da boa prática empresarial, administração modelo, administração participativa, administração com qualidade total [...] eles fazem tudo soar tão racional, tão claro, tão certo. (MINTZBERG et. al. 2006, p.61)

\subsection{Comentários finais sobre avaliação}

Apesar de os modelos serem claros em alguns aspectos, a prática das organizações parece evidenciar as dificuldades do uso:

Enquanto a idéia de costurar o sistema de avaliação de desempenho das empresas à sua estratégia é considerado senso comum, vários estudos conduzidos ao longo dos anos indicam que muitas companhias falham em implementar isso apropriadamente. Mais de 20 anos atrás, por exemplo, Steven Kerr (hoje vice-presidente e gestor do conhecimento da GE) escreveu um artigo intitulado "Recompensando A, enquanto deseja-se B." Esse artigo, agora um clássico, descrevia como muitos sistemas de avaliação de performance das empresas recompensavam comportamentos diferentes daqueles que esperavam obter do seus empregados. (EPSTEIN; MANZONI, 1997, p.28) ${ }^{32}$

Para se agravar esse fato, os avanços tecnológicos possibilitaram a criação de softwares e de acesso à informação em níveis sem precedentes. Deve-se notar que, apesar do destaque da literatura para uma elaboração de sistemas de avaliações de performance alinhados aos objetivos estratégicos da organização, muitas vezes a resposta fácil ainda seduz os executivos, como transparece, por exemplo, na descrição da implementação de um sistema de avaliação

\footnotetext{
${ }^{31}$ No original: There is a great deal of literature out there by different software vendors and consulting companies that define what their methods are and what their products do, but they also use inconsistent definitions, adding to the confusion.

32 No original: While the idea of tailoring the company's performance measurement system to its strategy is common sense, several studies conduced over the years have noted that too many companies fail to implement it properly. More than 20 years ago, for example, Steven Kerr (Now vice president and chief learning officer at GE)wrote an article titled "On the folly of Rewaring A, hoping for B" This article, now considered a "classic", described how many companies performance measurement systems were rewarding different behaviors than the ones they hoped to obtain from their employees. Our recent observations suggest that the "folly" identified by Kerr is still alive today.
} 
semelhante ao Balanced Scorecard em uma empresa de seguro saúde: "Ainda que nosso primeiro pensamento sobre como padronizar a gestão de performance tenha sido implementar um software de gestão de performance, nós rapidamente percebemos que o software não era a solução."33 (MORETTI, p.213)

Os avanços tecnológicos recentes influenciaram profundamente as empresas, e graças a maior capacidade de processamento, ao aumento da informatização dos diversos sistemas gerenciais, e a melhoria das comunicações e das redes de computadores, ficou mais fácil coletar dados para os sistemas de avaliação. Entretanto, como apontam Lawson et al. (2006), criaram-se novos desafios por essa realidade:

- Métricas em excesso;

- Muitos dados, sem obter informação gerencial desses;

- Problemas com as estratégias de longo prazo;

- Necessidade de respostas mais rápidas às mudanças de mercado e pressões competitivas;

- Estratégia com pouco ou nenhum impacto em atividades do dia-a-dia da organização;

- Prestação de contas apenas em planos de longo prazo;

- Recursos financeiros desvinculados da estratégia;

- Necessidade de ser capaz de executar melhor a estratégia.

Assim, a prática da avaliação revelou-se mais complexa do que se poderia supor. Um aspecto intrigante é a elaboração das métricas e indicadores essenciais em uma avaliação quantitativa. Hammer (2007, p.43) lista em artigo recente sete erros comuns à elaboração dessas métricas, concatenados à prática do que aos modelos usados em sua elaboração:

- A tendência, quando há recompensas envolvidas, a escolher métricas que fazem os administradores parecerem bons e competentes, por exemplo a escolha dos parâmetros de prazos de entrega fáceis de cumprir, o que pode gerar um índice alto de "pedidos entregues no prazo", mas deixar os clientes insatisfeitos com a empresa;

- A tendência da organização e dos departamentos a estabelecer metas dentro de sua realidade parcial. Por exemplo, é comum o departamento de vendas, que medem o resultado em volume de vendas, enfrentarem conflitos com o departamento de produção, pois esses medem os

33 No original: Though our first thought on how to standardize performance management was to implement performance management software, we quickly realized that software wasn't the answer. 
resultados, focando em inovação, custos e produtividade, ou com marketing, que não avalia custos nem vendas, mas satisfação dos clientes;

- A tendência a ignorar o consumidor ao estabelecer as métricas. Por exemplo, as companhias de call-center que avaliam o número de pessoas atendidas, e não o número de problemas resolvidos;

- A tendência a definir os aspectos a se mensurarem sem pensar muito a respeito, por que é óbvio. Por exemplo, muitas empresas utilizam as métricas que já possuíam, e não se questionam a respeito, dado o sistema já coletar esses dados;

- A tendência a medir apenas uma pequena parcela do que importa realmente;

- A tendência a implementar métricas sem se preocupar com as conseqüências, por exemplo o autor cita uma rede de fast-food; a fim de diminuir o desperdício, avaliado por uma nova métrica, os cozinheiros da cadeia passaram a preparar a comida somente após o pedido. $\mathrm{O}$ resultado foi menos desperdício, entretanto mais filas e menos vendas;

- A tendência a questionar as métricas e seus resultados quando não são satisfatórios, ou seja, procurar culpados em vez de aprimorar o processo.

Cunha, Corrêa e Calegari (2007) analisam que não se podem observar aspectos como a inovação apenas percentualmente em relação à evolução temporal das inovações da organização. Para os autores deve haver a observação das inovações também em relação à relevância em comparação com as da concorrência.

Além dessas questões, há outros aspectos práticos na avaliação de desempenho que merecem se discutir. Corrêa observa ser muito importante saber quem faz a avaliação de desempenho, e sua posição dentro da empresa e em relação aos demais setores. (op. cit, p.189). Pouco se aborda essa questão nos diversos modelos, mas é especialmente relevante para as empresas estatais estudadas neste trabalho, e também para as franquias. É provável que uma avaliação implementada por um único chefe de projeto, ligado à alta administração, conforme o Balanced Scorecard, difira em resultados de outra, realizada a cada área da organização, como propõe a APO.

Conforme Corrêa (1986, p.124-132) os diferentes bloqueios para a eficácia de um processo de avaliação de desempenho podem se classificar em quatro tipos:

- Gerenciais - relativos à gestão, práticas, estilos, objetivos e ações;

- Pessoais; 
- Metodológicos;

- Ambientais (político - social): relativos às influências externas ao negócio.

Corrêa acrescenta que esses bloqueios deverão ser tratados e considerados face às especificidades de cada organização.

Melissa Conley-Tyler (2005, p.4) acrescenta ainda outra questão: a pergunta “quem?”. A avaliação deve ser conduzida por uma equipe interna, ou externa? A literatura gerencial normalmente diz que deve ser um processo interno, mas não é o único ponto de vista. $\mathrm{Na}$ verdade, em muitos casos ocorre avaliação por grupos externos, também influenciando profundamente as empresas. Na revisão dos modelos de avaliação proposta por Hourneaux, aparecem os prêmios de qualidade, como o prêmio Deming, o prêmio Malcom Baldrige nos EUA ou o Prêmio Nacional de Qualidade (op. cit, p.47-53), elaborados não apenas para avaliar o processo de gestão, mas também para direcionar as mudanças e provocá-las nas organizações. Também no sistema de franquias ocorrem premiações e certificações, como o Selo de Excelência em Franchise, concedido pela ABF.

\subsection{0_A avaliacão de desempenho em franquias.}

Os sistemas de avaliação, tão utilizados em grandes empresas atualmente, aparecem pouco na literatura sobre pequenas empresas. O Balanced Scorecard, por exemplo, é considerado por alguns um sistema freqüentemente utilizado nas grandes organizações.

No entanto, uma revisão de literatura, de Janeiro de 2000 à Setembro de 2003, nos periódicos Journal of Small Business Management, Journal of Business Venturing, Entrepreneurship Theory and Practice, International Small Business Journal, e the Journal of Small Business Strategy, não retornou artigos com Balanced Scorecard no título. Uma busca por BSC, através de todos os artigos também não encontrou nenhum destes periódicos, nem outros periódicos sobre pequenos negócios e empreendedorismo, incluindo o tópico BSC. ${ }^{34}$ (GUMBUS e LUSSIER, 2006, p.407)

\footnotetext{
${ }^{34}$ No original: However, a review of the literature, from January 2000 to September 2003, of the Journal of Small Business Management, Journal of Business Venturing, Entrepreneurship Theory and Practice, International Small Business Journal, and the Journal of Small Business Strategy resulted in no papers with $B S C$ in the title. A general BSC search throughout entire articles also did not find any of these journals, nor any other small business/ entrepreneurship journals, including the topic of the BSC.
} 
As franquias configuram-se como um arranjo com características de pequena e grande empresa simultaneamente, pois nestas ocorre não só a presença de um controlador do sistema, o franqueador, mas também de um pequeno empreendedor, o franqueado. No caso das franquias, também há pouca literatura sobre os sistemas de avaliação de desempenho, todavia há referências que indicam sua utilização e as causas desta. Entre os poucos textos encontrados, há o de Ikeda (1998), que propõe um sistema de avaliação da eficácia das lojas franqueadas por meio de uma ferramenta de análise de dados, o Data Envelopment Analisys. Silva descreve uma evidência do uso da avaliação, ao informar em seu trabalho que o plano real exigiu da empresa Habib’́s um maior controle sobre os custos de produção, além da percepção de que a padronização e a qualidade dos produtos tornaram-se fatores essenciais no segmento das franquias de alimentos. (SILVA, 1999, p.109)

Ribeiro (in CHERTO et. al., 2006, p.270) recomenda a construção de indicadores e a definição de metas, principalmente nas atividades que geram resultados, sejam receitas ou despesas, visando maior lucro para a unidade franqueada.

Há especificidades na relação de franquia, quando comparadas às outras organizações, que devem influenciar o seu sistema de avaliação: a relação de parceria franqueador-franqueado; a marca como um ativo muito forte (MERLO, 2000); as parcerias trianguladas com fornecedores; a confiança e a relação contratual que regulam a parceria; a origem dos ganhos dos franqueadores sobre taxa de royalty ${ }^{35}$ e vendas de licenças, entre outras características únicas.

Por que as relações de parceria entre franqueador e franqueado influem num sistema de avaliação das franquias? As relações de parceria, como numa franquia, dependem especialmente de uma avaliação de desempenho. Eis alguns problemas, a seguir, que podem ocorrer entre parceiros se não há preocupação em avaliar resultados.

\footnotetext{
35 Os royalties podem ser valores fixos por unidade ou podem ser cobrados como uma taxa variável em relação ao faturamento. Frazer (1998, p.594) teorizou, e encontrou evidências, numa pesquisa com 262 franqueadores na Australia, que as atividades de monitoramento do franqueado por parte do franqueador é menor, caso haja cobrança de uma taxa fixa do franqueado ao invés de uma percentagem de vendas; assim é mais provável o uso de visitas constantes, de espiões e de mais relatórios quando o contrato prevê o pagamento de percentagem de vendas ou faturamento. Por outro lado, o mesmo trabalho não encontrou evidências de que as dificuldades de monitoramento correlacionam-se com o uso da taxa fixa. Para avaliar as dificuldades de monitoramento, consideraram-se a dispersão geográfica, o número de escritórios próximos, e o setor (serviços ou indústria).
} 
Quando um parceiro não pode demonstrar resultados, diminui sua capacidade de comunicação com os stakeholders para mobilização de novos recursos (HALAMICH, 2005, p.504). Em franquias, a gestão de fundos dos franqueados pelo franqueador, como no caso de verbas de publicidade, é suscetível a problemas dessa ordem. Nesse exemplo, pode ocorrer também questionamento no uso das verbas, possivelmente evitado se houver uma preocupação em documentar os processos e avaliar os resultados por parte do franqueador. Logo, fica claro que uma avaliação de desempenho, ao menos para certo nível de atividade, é essencial no caso das franquias, não apenas para o conhecimento do franqueador, mas também para prestar contas e esclarecimentos ao franqueado, aos candidatos a fraqueados, e aos outros parceiros da rede.

Andrade enumera algumas razões para a existência de controles e avaliações em um sistema de franquias, relacionadas "com os potencias de ganho da rede, outras, com necessidades próprias do franqueador (como é o caso do controle sobre o faturamento, quando a cobrança de royalties pelo franqueador baseia-se nesse parâmetro)." (ANDRADE, 1993, p.27)

Ainda reforçando a questão da necessidade de avaliação, a legislação brasileira, Lei 8955 (BRASIL, 1994), posiciona-se obrigando o franqueador a prestar uma série de informações padronizadas sobre a rede na circular de oferta e franquia, bem como a deixar claro já nessa peça qual a supervisão oferecida, conseqüentemente qual o controle exercido nas atividades do franqueado. Por se tratar de um sistema em que o franqueador procura manter e expandir a rede pela manutenção e captação de novos franqueados, há freqüentemente que se apresentar à rede e aos candidatos a franqueados outras informações sobre a rede e seu desempenho.

Essa consideração revela mais um aspecto da avaliação de desempenho em redes de franquias. Em algumas das metodologias de avaliação organizacional através de indicadores estratégicos, os autores dizem que os índices não devem ser fixos, e cabe a cada organização revê-los a certa periodicidade. Entretanto, a necessidade de se prestar contas do desempenho, e de se captarem novos franqueados implica que, ao menos, alguns indicadores não devem também variar muito, caso contrário haverá dificuldade em comparações de períodos. Implica também haver o risco de seleção de indicadores pensando na captação de franqueados, e não na avaliação como instrumento de gestão. Nesse caso, as medidas podem mostrar uma organização com bom desempenho, mas que não está realmente em boas condições. 
Corrêa e Hourneaux (2006, p.13) explicam que um dos aspectos mais relevantes do processo de avaliação de desempenho, segundo a literatura,

diz respeito àqueles que justamente encontram-se no meio dos processos organizacionais e são por eles, ao mesmo tempo, responsáveis e afetados, ou seja, as pessoas. Geralmente, a mensuração de desempenho não é uma atividade popular.

As avaliações podem provocar situações de conflito (HOURNEAUX, 2005). Nesse sentido, o Balanced Scorecard teve um interessante efeito em uma pequena empresa estudada por Gumbis e Lussier: seu uso fez a equipe questionar se o sistema de medição de performance não teria como objetivo fazê-los trabalhar mais arduamente. $O$ gerente explicou aos empregados que "esse era o objetivo da mensuração e o trabalho da gerência responsável é focar na eficiência." (GUMBIS e LUSSIER 2006, p.420).

Nem todas as empresas encontram gestores tão diretos como os desse caso, ainda assim, há que se considerar em que medida a avaliação de desempenho gerará desconforto na equipe quando aplicada aos indivíduos, e também se há algum problema com isso, ou como sugerido pelo gerente citado, às vezes, acabar com o conforto é parte da proposta.

Marcelo Andrade (1993, p.27) apresenta a questão do conflito decorrente da avaliação e dos controles, no universo das franquias. Segundo o autor: "Não é pouco importante a percepção que o franqueado tenha dos controles que lhe são impostos; ressentimentos nesse campo podem dificultar sobremaneira o relacionamento franqueado-franqueador, que como vimos deve ser cooperativo"

Além disso, a relação de parceria pode ocultar situações típicas do conflito entre agente e principal. Apresenta-se um bom exemplo de uma situação na qual a avaliação de desempenho por parte do franqueador sobre as atividades do franqueado é crítica, e por outro lado, difícil, no trabalho de Vivian Silva, ao descrever as taxas contratuais da empresa Arby's:

Mensalmente, o franqueado deverá apresentar um demonstrativo de lucros e perdas por filial, depositando a crédito do franqueador o valor correspondente a $5 \%$ do faturamento mensal bruto. $\mathrm{O}$ franqueado também deverá destinar $4,5 \%$ do faturamento bruto para despesas de marketing. Até $1 \%$ desta verba deverá ser colocada à disposição do franqueador, que remeterá para a Arby's International, para custeio de produção de materiais. (SILVA, 1999, p.88) 
Essa é a típica situação descrita como um conflito de agência, já que o franqueado, nesse caso o agente, pode se beneficiar de passar resultados falsos (piores) para o franqueador, tendo um ganho individual, em detrimento do resultado da rede. Obviamente, essa apropriação de uma parcela maior do resultado da operação prejudica as atividades de marketing da rede como um todo, pois diminui os recursos disponíveis, e também a qualidade dos serviços prestados pelo franqueador. "As taxas baseadas em porcentagens fiam-se na crença de que os franqueados abrem seus movimentos, e as evidências sugerem que a trapaça por parte dos franqueados pode ser um fenômeno comum." 36 (ACHESON, 1996 apud. FRAZER, 1998, p.591). Esse tipo de situação leva à suposição de que o franqueador tenha processos para conferir as informações fornecidas.

No trabalho de Silva (1999), há evidências de que os franqueadores verificam as informações prestadas pelos franqueados, e muitas vezes optam por coletar informações não com os franqueados, mas sim em outras etapas da cadeia produtiva. A autora descreve como a Arby's, com operações encerradas no Brasil, centralizava a negociação com os fornecedores das franquias de mais de 470 itens, como pão, queijo, batatas curly e roast beef. A Arby's também centralizava a distribuição através da empresa Logway, que utilizava um sistema eletrônico para verificar estoques e agendar entregas. Segundo a autora:

A estrutura centralizada permite, também, o fornecimento de estatísticas de compras consolidadas, como relatórios de produtos, loja, região, ou mesmo franqueado. Isso proporciona um maior controle sobre a atividade das lojas e um ajustamento sobre as ações do franqueado ou gerente, ao verificar, por exemplo, se suas compras estariam se restringindo apenas aos fornecedores credenciados pela rede; ou mesmo o acompanhamento de seu faturamento, a partir do volume de compras ou de vendas. (SILVA, 1999, p.102)

É importante considerar também que outras redes de alimentação centralizam a produção de insumos, como o Habib’s, que conta com 6 centrais de distribuição. Essa atitude permite obter informações confiáveis sobre as operações de cada unidade, facilitando o monitoramento. "O Habib’s atua diretamente na coordenação da cadeia de suprimentos, podendo se identificar o favorecimento de subsistemas estritamente coordenados" (SILVA, 1999, p.108).

\footnotetext{
${ }^{36}$ No original: Percentage-based fees rely on franchisees to disclose their turnover and anecdotal evidence accurately suggests that cheating by franchisees may be a widespread phenomenon
} 
Zimmermann (2002) faz duas considerações sobre a implantação de um sistema de avaliação em uma cadeia de suprimentos da indústria química, as quais parecem relevantes para a relação de franchising, já que similarmente essa relação também incorpora parcerias entre empresas; a primeira é:

No entanto, desde que o desenvolvimento de um Balanced Scorecard para a cadeia de suprimentos envolve revelar objetivos e informações da companhia, sua implementação não é factível se não houver confiança mútua entre as companhias parceiras. Levando isso em consideração, um Balanced Scorecard compartilhado por todas as companhias envolvidas em uma cadeia de suprimentos vai requerer confiança em toda sua extensão. (ZIMMERMANN, 2002, p. 413). ${ }^{37}$

A escolha e compra de uma franquia e um processo de estudo e construção de relacionamento entre franqueador e franqueado excedem tradicionalmente a simples relação de fornecedor e consumidor. Assim, é razoável supor que ocorra uma relação de confiança entre as partes. No entanto, como já apontado, é possível que os indicadores de desempenho construam-se também com o objetivo de evitar traições dessa confiança, além de ocorrerem eventualmente quebras de confiança e conflitos entre as partes.

A segunda assertiva do autor, que traz um paralelo relevante, é:

O conceito tradicional do Balanced Scorecard é focada em companhias individuais, assim não inclui indicadores de performance sobre as relações entre companhias. Se o BSC é aplicado ao gerenciamento de uma cadeia de suprimentos, é necessário incorporar estes indicadores, assim como indicadores de desempenho para as empresas individuais. (ZIMMERMANN, 2002, p. 410). ${ }^{38}$

Da mesma forma, considerando-se que a franquia compõe-se de diversas empresas, franqueados e franqueador, um sistema de avaliação de desempenho completo para a rede deve contemplar indicadores de desempenho que focalizem cada uma das empresas, e outros que focalizem a relação entre elas.

\footnotetext{
${ }^{37}$ No original: However, since the development of a Supply Chain Balanced Scorecard involves revealing company objectives and data, its implementation is not feasible if trust does not exist between the partnering companies. Taking this into account, a Balanced Scorecard shared by all companies in the supply chain would require extensive trust throughout.

${ }^{38}$ No original: The traditional Balanced Scorecard concept is focused on individual companies and therefore does not include inter-enterprise performance measures. If the Balanced Scorecard is applied to the management of supply chains it needs to incorporate inter-enterprise performance measures as well as individual enterprise performance measures.
} 
Uma última observação sobre o processo de construção de um scorecard para uma cadeia de gestão de suprimentos, considerando à perspectiva do sistema de franquias, é a reflexão de Ackerman (2003, apud BUENO, 2004). No desenvolvimento de um sistema de avaliação de performance com várias empresas, não são os indicadores em si os melhor resultados obtidos, mas o relacionamento e confiança que resulta do processo.

Há nos processos de avaliação também outras preocupações, relacionadas ao ganho da cadeia produtiva e ao estreitamento da relação de confiança com os fornecedores. Como já apontado, o monitoramento em redes de franquias acontece não apenas sobre as organizações diretamente incorporadas ao contrato (franqueador e franqueado), mas também em muitos casos sobre os parceiros, em especial os fornecedores, conforme Vivian Silva:

Finalizando o processo, a Arby's realiza um acompanhamento contínuo quanto à produção, identificando possíveis ajustes e analisando a adequação do parceiro no processo estipulado. No entanto o objetivo é que o parceiro seja o especialista na produção, como o detentor de maiores detalhes sobre o processo. (SILVA, 1999, p.94)

Esse processo de aprimoramento dos fornecedores relaciona-se com os conceitos de melhoria da qualidade, o que, conforme apresentado, é umas das principais preocupações dos processos de avaliação de desempenho. Sistemas como o Balanced Scorecard, e prêmios que avaliam as empresas, como o Prêmio Nacional de Qualidade, ou o Prêmio Deming, listam entre seus propósitos a melhoria da qualidade (HOUNEAUX, 2005). Prêmios e certificações também são promovidos pela $\mathrm{ABF}$, com o mesmo intuito de aprimorar os processos das franquias existentes, e chancelar a qualidade das empresas que operam no setor. Um exemplo é o Selo de Excelência em Franchising 2008. No caso dos sistemas de franquias, a afirmação a seguir evidência a importância da qualidade:

Se a qualidade é importante em qualquer negócio, no franchiing o é de modo particular. Por um lado o franqueador precisa proteger a reputação da sua marca registrada, que juntamente com o 'know-how' e a experiência acumulada, é o seu principal patrimônio. Por outro lado, a qualidade de cada franqueado percebida pelo mercado repercute por toda a rede, com impacto mais forte, é claro, naquelas unidades que pertençam à mesma comunidade e região. (ANDRADE, 1993, p.24)

O autor refere-se ao "efeito rede", que tem reflexos na percepção dos clientes, mas também na motivação dos outros franqueados. A marca é um dos ativos principais do franqueador, e o 
monitoramento das atividades do fraqueado liga-se diretamente ao sucesso da marca. Entre as vantagens do sistema da franquias, Cherto diz:

- pela própria natureza do franchising, a possibilidade de exercer legalmente, sobre as atividades do franqueado, um grau de controle bastante superior e normalmente muito mais efetivo do que seria possível exercer com relação a outros canais de venda [...] ocorre o fortalecimento da marca, em função desse nível de controle [...](2006, p.42)

Assim, os sistemas de avaliação de desempenho em franquias são fundamentais, a fim de assegurar a manutenção da qualidade e a valorização de uma marca ao criar valor para os clientes da rede.

Corrêa (1986, p.123) observou em sua tese sobre avaliação da empresa estatal que "a empresa pública tem entre seus objetivos o componente social que é de difícil quantificação". Pode-se expandir essa observação, considerada no contexto atual da responsabilidade social, para todas as empresas e organizações preocupadas com sua atuação social e com a imagem que transmitem. Caso dos sistemas de franquias, já que certamente preocupam-se com a imagem transmitida, além de ser exatamente o uso de uma marca forte que consolida cada franquia. Portanto deve-se considerar que a avaliação da atuação social das empresas, e em especial das franquias, também deveria ser contemplada, o que, similarmente ao que ocorre na empresa pública, é tarefa árdua, considerando que a empresa socialmente responsável não é necessariamente aquela que atua em alguns projetos sociais restritos, muitas vezes parecidos excessivamente com publicidade, e que posteriormente põe tudo a perder, pois não preservam uma relação adequada com os diversos stakeholders.

A valorização da marca implica o controle efetivo do franqueado, por outro lado esse não é o único aspecto de uma avaliação de desempenho, e nem mesmo é o mais importante. Infere-se que a principal razão para avaliar o desempenho de uma rede de franquias e de cada unidade franqueada é assegurar a sobrevivência e o sucesso do franqueador e dos franqueados. Nas palavras de Lindolfo Martin, proprietário da franquia Multicoisas, relatadas no livro Franchising na prática:

[...] esse processo de insucesso do franqueado acho que é mais angustiante para o franqueador, principalmente no início da rede, quando ele não pode contar com essa hipótese, de ter alguém que investiu dinheiro no seu negócio e fracassar. Nós criamos o IDO - Indicador de Desempenho 
Operacional, que é um mapa formulado em dois momentos: o administrativo e o comercial. Então pretendemos com esse acompanhamento, com essa fotografia tirada mês a mês, evitar que isso ocorra. (RIZZO e CHERTO, 1994, p.55)

A revisão bibliográfica revelou também influências dos diferentes modelos de avaliação nas redes. Em debate ocorrido antes do plano real, no governo Collor, relatado na obra de Rizzo e Cherto (ibid.), o então presidente do McDonald’s no Rio de Janeiro, Peter Rodenbeck, fez a seguinte declaração:

Há dois pontos a se observar. Tem o acompanhamento mensal, que é uma estatística dos dados operacionais, com 20 ou 25 dados básicos que coletamos de todas as lojas, inclusive nossas, e redistribuímos. Com isso, o licenciado tem condições de analisar a loja dele em comparação com toda a rede. São dados operacionais detalhados: custo, consumo de energia, etc. E tem uma coisa chamada revisão do negócio, que é feita anualmente, em que combinamos toda aquela avaliação do operador com outros fatores do negócio, ou seja, revisamos nessa hora como é que ele está graduado: por exemplo, "A" em qualidade, "A" em serviço, "A" em limpeza. Nós acrescentamos uma avaliação da administração dele. A questão sobre contadores é muito importante, Lindolfo pode falar mais sobre isso. Damos, então, um veredicto, se ele é "expansível" ou não. Nessa mesma reunião, é feito um plano com as metas para o ano: metas de vendas, metas de desenvolvimento de pessoas, metas operacionais. (ibid, p.53)

O trecho evidência um sistema com princípios ligados a APO e também com o uso de poucos indicadores e outros aspectos que tornem o entendimento relativamente simples pelos usuários. Nos sistemas de avaliação aplicados em franquias, é esperável que a simplicidade seja a regra, dadas as prováveis dificuldades de uma parcela dos franqueados, especialmente dos sem experiência em gerir negócios, em utilizar instrumentos de gestão complexos. Além disso, a confusa realidade brasileira criou uma cultura em que medir resultados não era uma atividade valorizada, e só recentemente tem se modificado nas organizações.

Historicamente a inflação elevada, que durou até quase a metade da década de 90, dificultava a comparação de resultados. Agravou-se esse quadro também porque parte dos pequenos empreendimentos que optam por trabalhar na informalidade, com caixa dois, um eufemismo para a sonegação de impostos; os contadores e escritórios de contabilidade, ao invés de controlar o resultado real das empresas, acabam tendo apenas o controle do "caixa 1", fictício. Essa cultura está presente em diversas micro-empresas brasileiras. 
As unidades franqueadas são, em sua maioria, micro ou pequenas empresas e assim é natural supor que se sintam estimuladas a adotar a mesma prática, a fim de obterem competitividade e enfrentarem uma concorrência que paga menos impostos. As franquias apresentam ainda mais essa dificuldade no caminho da avaliação de resultados.

Conforme apresentado por Lindolfo Martin, franqueador da rede Multicoisas, e transcrito na obra de Rizzo e Cherto (1994):

\begin{abstract}
Os conflitos, se bem resolvidos, fazem o sistema crescer. Tenho o caso dos contadores locais, que queriam questionar o conceito de transparência sugerido pelo sistema; tive muitos problemas com esses contadores. Hoje, nosso problema, inclusive para admissão de contadores para o franqueado (SIC), é de licenciar ou autorizar o contador, procurando fazer sempre uma sabatina com relação a esse conceito. Porque normalmente eles procuravam minar meu franqueado com colocações do tipo: 'você está louco, você vai quebrar se vender tudo com nota'. E ele não tinha culpa, pois jamais tivera um cliente com tal postura. E tem um problema: o contador era um aliado do dia a dia do franqueado, e eu estava a setecentos quilômetros de distância. Essa figura é muito importante nas minhas novas franquias, e tenho de trazer o contador para bem próximo do sistema. (RIZZO e CHERTO, 1994, p.47)
\end{abstract}

Todos esses aspectos provavelmente influenciam o sistema de avaliação das franquias.

Por último, ressalta-se que franqueador e franqueado operam como um sistema, mas ainda assim são partes independentes, ou seja, são empresas distintas. No entanto, o fato de constituírem pessoas distintas, mas que atuam em cooperação, evidencia a importância da parceria, da confiança e dos ganhos mútuos na relação. Evidencia também a importância para cada parte de conhecer como estão os parceiros, propósito da avaliação. Uma explicação simples para o franchising relaciona-se à idéia de ganhos mútuos, em que tanto franqueador quanto franqueado sabem que haverá um ganho maior pela atuação em conjunto, constituindo-se numa relação de soma não nula (WRIGHT, 2000).

Relações de soma não zero são aquelas em que o ganho da atuação conjunta é maior do que o total dos ganhos das atuações individuais (WRIGHT, 2000). Exemplificando, quando duas mães vizinhas acertam um sistema de caronas para levarem e buscarem os filhos à escola, ambas ganham mais tempo, pois não precisam mais levar o próprio filho todos os dias, e tem um menor custo, já que devem apenas ceder um espaço no carro ao filho da vizinha nos dias que são responsáveis pela ida à escola. $\mathrm{O}$ mesmo acontece entre franqueador e franqueado, 
havendo da parte do franqueado a convicção de que ingressar na franquia diminui riscos e aumenta sua chance de sucesso; da parte do franqueador, a certeza de contar com um canal de distribuição tão preocupado com o sucesso quanto ele (CHERTO et al., 2006). Isso se reflete sobre os sistemas de avaliação de desempenho. A partir dessa constatação, Andrade faz uma interessante colocação:

Gostaríamos de destacar esse aspecto de troca que se realiza entre duas partes independentes. $\mathrm{O}$ franqueado está tanto mais crítico aos controles (e a atuação em geral) do franqueador quanto menores forem os ganhos reais que perceba com sua perda de autonomia. Daí a importância de o franqueador, por exemplo, associar à inspeção serviços que tragam benefícios significativos aos franqueados, ou de explicar o porquê de cada controle que exerça sobre eles. ${ }^{39}$ (ANDRADE, 1993, p.28).

Assim, se o franqueado percebe valor em uma avaliação de desempenho global, certamente será mais simples a atuação dos responsáveis pela avaliação. Por outro lado, se os ganhos são mútuos, haverá também o empenho do franqueador a fim de obter o máximo da avaliação.

É ainda importante salientar que os interesses do franqueador ou as especificidades da rede provavelmente influenciam o sistema de avaliação. Segundo Agrawal e Lal (1995), o interesse do franqueador em investir na marca aumenta com a taxa de royalty, e o interesse do franqueado de prestar um bom serviço diminui. Os autores encontraram evidências, ao analisar 43 franqueadores, de que a frequiência de monitoramento (visitas surpresas) pelo franqueador aumenta com a taxa de royalty, mas o aumento no custo de monitoramento leva a um nível de serviço pior dos franqueados (produtividade). Assim, para eles, a cobrança de royalty influi no processo de avaliação.

\footnotetext{
${ }^{39}$ Grifo no original.
} 


\section{METODOLOGIA}

O propósito da metodologia é descrever os procedimentos adotados, a fim de atingir o objetivo do estudo.

\subsection{Objetivos do estudo}

Este trabalho tem como objetivo geral:

Identificar e descrever a utilização dos sistemas de avaliação de desempenho e suas características em organizações que operam através das redes de franquias.

\subsection{Definicão das questões de pesquisa}

Dessa forma, pautar-se-á a busca pelo conhecimento sobre o assunto nas respostas à seguinte pergunta, de caráter geral:

- Quais as características de um sistema de avaliação de desempenho aplicado pelo franqueador no setor de franquias?

Com o objetivo de respondê-la, elaboraram-se outras perguntas, que o estudo responderá para atingi-lo:

- O sistema de franquias é avaliado pelos franqueadores?

- Quem é responsável pela execução das avaliações?

- Essas avaliações têm quais objetivos?

- Quais os critérios/ dimensões / módulos contemplados nessas avaliações?

- Como são realizadas as avaliações?

- Qual a sua periodicidade?

- Os avaliados têm acesso ao resultado da avaliação?

- Essas avaliações, e seu processo, geram conflitos? Quais?

- Como são resolvidos esses conflitos?

- De que forma utiliza-se o resultado destas avaliações? 
- A tipologia da rede de franquias influencia o sistema de avaliação? (tamanho da rede, forma de remuneração, idade da rede, gestão).

Quanto a essas perguntas, espera-se também verificar a possibilidade de que conflitos decorrentes da avaliação ocorram entre as organizações envolvidas, e que os sistemas de avaliação utilizados não sejam apenas ferramentas de diagnóstico, mas também de comunicação estratégica e gestão de conflitos.

\subsection{Método da pesquisa}

O objetivo de uma pesquisa é responder perguntas com a utilização de processos científicos a fim de aumentar a probabilidade de que a informação obtida seja significativa para a pergunta feita, precisa e não enviesada. (SELTTIZ, 1974, p.5).

Para atingir esse objetivo, o presente estudo busca responder a questão: Quais as características principais de um sistema de avaliação aplicado pelo franqueador no setor de franquias? Segundo Gil (2002), as pesquisas classificam-se em exploratórias, conclusivas, descritivas e explicativas, de acordo com seus objetivos gerais.

Esta pesquisa apresenta caráter exploratório, dado o tema ainda ser pouco estudado, conforme revelado pela revisão bibliográfica, que não encontrou estudos qualitativos ou quantitativos que abarquem essa questão. Apenas a tese de doutorado de E. M. Merlo (2000) discute a questão genérica da performance em franquias, mas com foco em seus condicionantes, e não com a avaliação ou condução do sistema. A pesquisa exploratória, de acordo com Gil (ibid), visa proporcionar maior familiaridade com um problema com o objetivo de torná-lo explícito e construir hipóteses. Selttiz (1974, p.60) afirma que o objetivo de uma pesquisa exploratória é a formulação de um problema para investigação mais exata ou para a criação de hipóteses, com a finalidade de aumentar o conhecimento do pesquisador acerca do fenômeno que deseja investigar em estudo posterior, mais estruturado ou da situação em que pretende realizar tal estudo.

Além do aspecto exploratório, esta é uma pesquisa descritiva, visto que procura descrever as características do sistema, e não provar relações causais (MATTAR, 1996, p.76). 
O presente estudo foca as franquias geridas por relação contratual e, dentro desse grupo, especialmente as de formato de negócios (Business Format Franchising), ou seja, aquelas em que ocorre também a transferência de marcas, kwon-how, patentes, fórmulas, insígnias, e assistência técnica permanente do franqueador ao franqueado.

Num primeiro momento, elaborou-se uma revisão bibliográfica sobre os temas sistemas de franquias e avaliação de desempenho das organizações; utilizou-se o levantamento de dados secundários para auxiliar a formulação do instrumento de pesquisa, cujo objetivo é a coleta de dados primários sobre os sistemas de franquias, principalmente os de tipos descritivos, contemplando também dados comportamentais e preferenciais. A pesquisa tem caráter quantitativo, e devido ao seu aspecto exploratório, contempla variáveis nominais, ordinárias e intervalares.

O escopo de pesquisa quanto à profundidade foi o levantamento por meio de um questionário estruturado, enviado eletronicamente, associado a um posterior acompanhamento por telefone, caracterizando uma pesquisa Survey (COOPER; SCHINDLER, 2003, p.260).

A Survey é apropriada ${ }^{40}$ como método de pesquisa quando:

- se deseja responder questões do tipo 'o quê?', 'por quê?', 'como?' e 'quanto(s)?', ou seja quando o foco da pesquisa é sobre 'o que está acontecendo' ou 'como e por que isso está acontecendo?';

$[\ldots]$

- o ambiente natural é a melhor situação para estudar o fenômeno de interesse;

- o objeto de interesse ocorre no presente ou no passado recente. (FREITAS et. al, 2000, p.105-106)

\subsection{Universo da pesquisa}

A pesquisa discute as empresas franqueadoras na realidade brasileira nos diversos setores em 2007. Consideraram-se empresas internacionais por suas matrizes franqueadoras. O universo das franquias atuantes no Brasil não tem um número totalmente estabelecido, mas situa-se entre 1.000 e 2.000 unidades $^{41}$. Obtiveram-se os contatos para realização deste trabalho no Guia completo de franquias 2007 (INSTITUTO FRANCHISING, 2007), da Editora Empreendedor. O Guia completo de franquias contempla 621 franqueadores, que

\footnotetext{
${ }^{40}$ Grifo no original.

${ }^{41}$ Ver nota 8 , na página 16.
} 
compuseram a população da pesquisa. A tabela 5 relaciona a distribuição de franqueadores listados no Guia, por setores de atuação. Omitiram-se as duas franquias sociais, que não se constituem como empresas.

Tabela 5 - Universo da pesquisa por setores.

\begin{tabular}{lcc}
\hline Setor & Freqüência & F. relativa \\
\hline Alimentos & 113 & $18,3 \%$ \\
Cafeteria e confeitaria & 16 & $2,6 \%$ \\
Acessórios e calçados & 36 & $5,8 \%$ \\
Casa, decoração e presentes & 22 & $3,6 \%$ \\
Comunicação, fotografia, gráfica e sinalização & 22 & $3,6 \%$ \\
Educação e treinamento & 81 & $13,1 \%$ \\
Entretenimento & 17 & $2,7 \%$ \\
Hotelaria e turismo & 12 & $1,9 \%$ \\
Limpeza e conservação & 29 & $4,7 \%$ \\
Livrarias e papelarias & 9 & $1,5 \%$ \\
Negócios e serviços & 89 & $14,4 \%$ \\
Saúde e beleza & 84 & $13,6 \%$ \\
Veículos & 23 & $3,7 \%$ \\
Vestuário & 66 & $10,7 \%$ \\
\hline TOTAL & 619 & $100,0 \%$ \\
\hline
\end{tabular}

Fonte: Adaptado de Instituto Franchise, 2007, p.16

\subsection{Instrumento da pesquisa}

Para a realização do estudo, construiu-se um questionário, enviado aos franqueadores, buscando responder as questões de pesquisa. O questionário aplicado está disponível no Apêndice II. Sua primeira versão, em papel, aplicou-se por um pré-teste em um franqueador do setor de alimentação, com número de lojas franqueadas pequeno, logo depois modificado, devido a algumas dúvidas de seu representante. Eliminaram-se algumas perguntas, simplificaram-se outras, com o questionário final composto de 101 questões. Em seguida, aplicou-se o questionário por um novo pré-teste em um executivo de outra franqueadora (escola de idiomas, com grande número de lojas franqueadas), dessa vez em versão eletrônica. O segundo pré-teste permitiu ajustes finais de vocabulário.

O questionário final contempla questões que retornam variáveis de diferentes tipos. As variáveis propostas estão disponíveis no item de definições de conceitos 3.8. O questionário contemplou também duas questões abertas, para aprofundamento das respostas obtidas. 


\subsection{Amostra}

Como já indicado, o número exato de empresas franqueadoras é incerto; neste trabalho, convidaram-se 619 franquias para responder o questionário. A amostra obtida não se configura em amostra probabilística, pois não foi obtida em um sorteio, mas sim pelos 63 franqueadores que se dispuseram a responder a pesquisa.

\subsection{Estratégia de coleta e análise dos dados}

A coleta de dados deu-se através de questionários auto-administrados, por meio eletrônico. Enviou-se um e-mail, disponível no apêndice I, convidando os diversos franqueadores a responderem ao questionário, disponibilizado em endereço eletrônico na Internet. Armazenavam-se as respostas em um banco de dados, relacionadas ao e-mail do franqueador. Pode-se assim dizer que a apuração dos dados foi eletromecânica (TOLEDO e OVALLE, 1995).

A fim de melhorar o retorno dos questionários, realizaram-se diversos procedimentos propostos por Cooper e Schidler (op. cit, p. 261-262):

- notificação preliminar - através de um telefonema, avisaram-se os franqueadores sobre o envio do questionário, o propósito da pesquisa e o sigilo dos dados;

- patrocínio da Survey - pesquisas de instituições respeitadas podem aumentar o nível de resposta; na medida do possível, informou-se sua vinculação à Universidade de São Paulo e à Faculdade de Economia e Administração, notórios centros de pesquisa, dando credibilidade ao estudo;

- acompanhamento - utilizou-se o lembrete, um método bem sucedido para aumentar os índices de resposta, até duas tentativas, para cada questionário enviado.

Além dos procedimentos propostos pelos autores, adotaram-se outras medidas para aumentar o número de respostas. Não se enviou o questionário somente a um grupo de franqueadores da lista selecionados por amostragem probabilística, mas a todos, a fim de obter um tamanho de amostra que possibilitasse análises, sendo esperado um retorno de respondentes via Internet próximo a $10 \%$ dos e-mails enviados. O procedimento proposto pode gerar um viés, pois é provável que haja uma característica em comum, principalmente entre aqueles que optaram por responder ou os que optaram por não responder, e que essa característica distorça as conclusões do estudo. Com o propósito de diminuir esse viés, construiu-se o banco de dados 
eletrônico que armazena as respostas do questionário sendo possível saber se um respondente iniciou o preenchimento, mas o abandonou à medida que tomou conhecimento do teor do questionário.

Após a coleta de dados, ocorreu a tabulação e análise das respostas.

\subsection{Definicões teóricas das variáveis ou conceitos relevantes}

Este trabalho apresenta conceitos e termos que precisam ser relacionados a aspectos qualitativos, a fim de restringir os assuntos abordados e dirimir eventuais dúvidas de entendimento. Apresenta também variáveis quantitativas, necessárias para o entendimento das hipóteses construídas e verificadas. Sugere-se que as variáveis utilizadas na formulação de hipóteses classifiquem-se em dependentes e independentes, (CRESWELL, p.172). Utilizaram-se apenas variáveis independentes na análise estatística.

O questionário é composto por variáveis nominais, em sua maioria binárias, com respostas afirmativas ou negativas, além de outras, como: setor de atuação, quem participa na fase de definição dos objetivos e metas.

Também efetuaram-se questões que retornavam variáveis ordinais (e de contagem) na resposta, com intervalos de classe, por exemplo: "O franqueador avalia as lojas franqueadas de quanto em quanto tempo?". As variáveis obtidas eram: o número de indicadores construídos para as lojas próprias; o número destes para as lojas franqueadas; o número de metas/objetivos que o franqueador define para as lojas franqueadas ou para as lojas próprias; número de lojas; e número de lojas franqueadas. Além disso, o instrumento contemplava outras questões que geram variáveis ordinais, questões que aplicam escalas de sete pontos, em que: 1 = facilita muito a avaliação, 2 = facilita, 3 = facilita pouco, 4 = é neutro em relação à avaliação, $5=$ atrapalha pouco, $6=$ atrapalha, $7=$ atrapalha muito.

No instrumento, aplicaram-se também questões como: "Há quanto tempo a marca começou a operar com sistema de franquias?". Questões desse tipo retornam variáveis quantitativas contínuas com mensuração intervalar. Outras questões como essas perguntavam aspectos relativos ao montante total investido e retorno do investimento do franqueado. 
As variáveis binárias propostas e listadas nas tabelas 6 e 7, contendo respostas afirmativas ou negativas em relação à aplicação nas franquias, construídas a partir da revisão bibliográfica, procuravam também verificar as dimensões ou módulos avaliados pelo franqueador.

Tabela 6 - Variáveis nominais binárias e módulos.

\begin{tabular}{|c|c|}
\hline Dimensão & Itens presentes na avaliação da franquia \\
\hline $\begin{array}{l}\text { Relativos às vendas. } \\
\text { (4 itens) }\end{array}$ & $\begin{array}{l}\text { Volume de produtos vendidos pela loja. } \\
\text { Volume de produtos vendidos para o franqueado. } \\
\text { Preenchimento dos pedidos (prazo, correção) } \\
\text { Giro de estoque do franqueado. }\end{array}$ \\
\hline $\begin{array}{l}\text { Aspectos } \\
\text { financeiros. ( } 7 \text { itens })\end{array}$ & $\begin{array}{l}\text { Lucro da loja. } \\
\text { Faturamento da loja. } \\
\text { Retorno sobre ativos na loja. } \\
\text { Custos operacionais da loja. } \\
\text { Despesas com impostos da loja. } \\
\text { Despesas financeiras da loja. } \\
\text { Outros aspectos financeiros. } \\
\end{array}$ \\
\hline $\begin{array}{l}\text { Aspectos relativos à } \\
\text { manutenção e } \\
\text { operação. (6 itens) }\end{array}$ & $\begin{array}{l}\text { Manutenção do maquinário/equipamento da loja. } \\
\text { Condições de higiene na loja } \\
\text { Condições do espaço físico (manutenção) } \\
\text { Atualização tecnológica (máquinas, softwares) } \\
\text { Uso do software de gestão } \\
\text { Outros aspectos de infra-estrutura } \\
\text { Consumo de energia/água da loja }\end{array}$ \\
\hline $\begin{array}{l}\text { Relativos à imagem } \\
\text { da marca. (4 itens) }\end{array}$ & $\begin{array}{l}\text { Respeito aos padrões da marca. } \\
\text { Condições de higiene na loja } \\
\text { Condições da fachada/vitrine } \\
\text { Participação da loja em ações sociais da rede }\end{array}$ \\
\hline
\end{tabular}


Tabela 7 - Variáveis nominais binárias e módulos.

\begin{tabular}{|c|c|}
\hline Dimensão & Itens presentes na avaliação da franquia \\
\hline $\begin{array}{c}\text { Aspectos relativos } \\
\text { aos clientes. ( } 7 \text { itens) }\end{array}$ & $\begin{array}{l}\text { Satisfação do cliente daquela loja } \\
\text { Mudanças na concorrência na região da loja } \\
\text { Fidelização dos clientes da loja } \\
\text { Perfil dos clientes da loja (renda, gênero) } \\
\text { Atendimento ao cliente na loja (tempo, pós-venda) } \\
\text { Mudanças relevantes na região (obras, shoppings) } \\
\text { Mudanças populacionais na região (perfil, densidade) }\end{array}$ \\
\hline $\begin{array}{c}\text { Aspectos relativos à } \\
\text { equipe. ( } 7 \text { itens) }\end{array}$ & $\begin{array}{l}\text { Satisfação / Motivação da equipe } \\
\text { Eficiência dos funcionários da loja } \\
\text { Treinamento do franqueado / gestor /administrativo } \\
\text { Treinamento do pessoal operacional } \\
\text { Qualidade do atendimento na loja } \\
\text { Identificação da equipe da loja com os atributos da marca } \\
\text { Rotatividade dos funcionários }\end{array}$ \\
\hline $\begin{array}{c}\text { Aspectos relativos à } \\
\text { logística das } \\
\text { operações. (6 itens) }\end{array}$ & $\begin{array}{l}\text { Uso dos softwares de gestão } \\
\text { Preenchimento dos pedidos (prazo, correção) } \\
\text { Estoque (variabilidade de tamanhos, tipos, moda) } \\
\text { Perdas de estoque (furtos, validade, acondicionamento) } \\
\text { Tempo de entrega dos produtos/insumos na loja } \\
\text { Recebimento dos produtos/insumos na loja }\end{array}$ \\
\hline $\begin{array}{c}\text { Aspectos relativos } \\
\text { aos parceiros. ( } 6 \\
\text { itens) }\end{array}$ & $\begin{array}{l}\text { Relacionamento do franqueado com fornecedores } \\
\text { Relacionamento com o franqueador } \\
\text { Participação da loja em ações promocionais da rede } \\
\text { Participação da loja em ações sociais da rede } \\
\text { Processos judiciais de terceiros contra a loja/franqueado } \\
\text { Participação do franqueado nos grupos de franqueados }\end{array}$ \\
\hline Inovação. (4 itens) & $\begin{array}{l}\text { Avaliação das inovações propostas à loja pelo franqueador } \\
\text { Avaliação das inovações criadas pelo franqueado } \\
\text { Atualização tecnológica (máquinas, softwares) } \\
\text { Avaliação das sugestões propostas pelo franqueado }\end{array}$ \\
\hline
\end{tabular}

O questionário também apresenta a opção de respostas afirmativas ou negativas para a presença das seguintes etapas no processo de avaliação:

- Definição da equipe responsável pela avaliação;

- Definição dos objetivos a serem atingidos;

- Definição dos dados a serem coletados;

- Definição das dimensões/módulos a serem estudados (financeiro, recursos humanos, clientes, etc..); 
- Definição dos pesos e critérios para cada item pesquisado;

- Construção de indicadores;

- Levantamento de dados;

- Integração dos resultados dos módulos ou dimensões;

- Comparação dos resultados obtidos com esperados e relatório final;

- Sugestões de mudanças;

- Punição em função do resultado medido;

- Premiação em função do resultado medido;

- Revisão dos objetivos;

- Revisão do sistema de avaliação.

Esses treze atributos são, portanto, outras variáveis binárias, relativas as etapas da avaliação. Além dessas variáveis, há outras quatro com respostas afirmativas ou negativas para definir o tipo de remuneração: Aluguéis; Royalty; Taxa Fixa; Na venda de produtos ao franqueado.

Tabela 8 - Tipo de variável obtida nas questões

\begin{tabular}{|l|ll|}
\hline Mensuração & Tipo & Questões \\
\hline Nominais & Binárias (sim ou não) & $\begin{array}{l}\text { 9 até 29, 32 (47 } \\
\text { atributos), 38, 39, 41a }\end{array}$ \\
\cline { 2 - 3 } & Outras & 1 e 37, 40, 41 \\
\hline Ordinais & Em escala de 7 pontos & 42 até 54 \\
\cline { 2 - 3 } & Outras & $\begin{array}{l}2 \text { até } 6,31,33,34,35, \\
36\end{array}$ \\
\hline Intervalares (discretas) & 7 e 8 \\
\hline $\begin{array}{l}\text { OBS: Questões } \\
\text { abertas }\end{array}$ & $30,41 \mathrm{~b}, 55$. \\
\hline
\end{tabular}

Este trabalho apresenta também termos não utilizados na análise quantitativa, mas cujos conceitos devem ser definidos e compreendidos pelo leitor, a fim de evitar confusões. Esses termos, organizados por relevância dentro do estudo, são:

Avaliação estruturada: processo de avaliação organizacional que contempla as seguintes etapas: a partir da estratégia da empresa, a definição de objetivos atingidos; definição dos dados coletados; coleta e análise de dados, comparação dos dados obtidos com os esperados. Conceito desenvolvido a partir do modelo de Boune et. al. (2000), que também prevê a revisão da estratégia. 


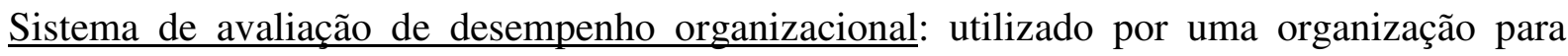
mensurar e avaliar seu desempenho. Apresenta enfoque sistêmico e estratégico, além de uma metodologia definida pela literatura administrativa, diferenciando-se, portanto, de softwares que se propõem a essa avaliação (HOURNEAUX, 2005, p.13). Deve-se ressaltar que esse conceito trata do desempenho global da organização.

Franchising (sistema de franquias): estratégia de expansão de negócios via cobertura e penetração de mercado. As franquias concedidas por uma organização são um canal de distribuição para os serviços ou produtos fabricados, gerenciados ou distribuídos pela organização de qualquer tipo (com ou sem fins lucrativos) (CHERTO, 2006). A concessão de uma franquia, essência do sistema de franquias, baseia-se em uma parceria entre duas pessoas físicas ou jurídicas, autônomas e independentes, reguladas pelo contrato de franquia.

Franqueador: pessoa física ou jurídica, detentora de uma marca, que se propõe a implantar uma rede para distribuição de seus produtos e/ou serviços mediante contrato, que inclui a autorização para o uso da marca por terceiros. (CRETELLA, 2003, p.27)

Franqueado: "pessoa física ou jurídica que se propõe a implantar a unidade de distribuição, de acordo com os padrões definidos pelo franqueador" (MAURO, 1999, p.69).

Franquia: unidade comercial franqueada. Significa também o direito de distribuição do produto ou serviço. Conforme a legislação brasileira:

Art. $2^{\circ}$ Franquia empresarial é o sistema pelo qual um franqueador cede ao franqueado o direito de uso de marca ou patente, associado ao direito de distribuição exclusiva ou semi-exclusiva de produtos ou serviços e, eventualmente, também ao direito de uso de tecnologia de implantação e administração de negócio ou sistema operacional desenvolvidos ou detidos pelo franqueador, mediante remuneração direta ou indireta, sem que, no entanto, fique caracterizado vínculo empregatício. (BRASIL, 1994)

Contrato de Franquia: Segundo Lafontaine (1992, p.264):

Um contrato de franquia é definido como um arranjo contratual entre duas empresas independentes, na qual o franqueador paga ao franqueado pelo direito de comercializar o produto e ou serviço, bem como a sua marca em um local e período determinados. 
Ainda sobre o aspecto jurídico, Cherto (ibid, p.24) apresenta o seguinte conceito:

Juridicamente, o franchising implementa-se através de um contrato, pelo qual a organização detentora de uma marca e dos seus conhecimentos relacionados a implementação, operação e gestão de um determinado tipo de negócio (a franqueadora), outorga a alguém, pessoa física ou jurídica, dela jurídica e economicamente independente (o franqueado), uma licença para explorar essa marca, em conexão com tais conhecimentos, com a finalidade de estabelecer e operar um negócio igual ou semelhante àquele cujo know-how o franqueador detém, ou seja, uma relação de franchising inclui a concessão e a garantia de acesso, pelo franqueador a cada franqueado, a uma série de direitos, conhecimentos, métodos, processos e sistemas, propriedade intelectual e industrial, imagem e "espaço" na mente dos consumidores, em suma, uma licença de uso de toda uma somatória de competências, as quais, combinadas da forma correta, constituem-se numa fórmula de sucesso.

Sistema de mensuração de desempenho: "conjunto de métricas utilizado para quantificar a eficiência e eficácia das ações." (NEELY, 2005, p.1229), ou seja, o sistema que permite a uma organização planejar, dimensionar e controlar seu desempenho, assegurando que as iniciativas de marketing e vendas, as práticas operacionais, os recursos tecnológicos, e as ações humanas alinhem-se à estratégia que cria valor ao acionista. (MAISEL, 2001, p.12 apud. FRANCO-SANTOS, 2007, p.790)

Medidas de Desempenho: "processo de quantificar a eficiência e eficácia das ações." $(\text { NEELY, 2005, p.1229) })^{42}$.

Sistema de Informação: "coleta, organização e distribuição de dados, de tal modo que eles se tornem significativos como informações.”(SILVA, 2004, p.334), ou seja, conjunto de procedimentos que, quando executados, produzem informação para apoio às decisões e controle organizacional. "Um sistema de informação envolve não somente a tecnologia, mas também as pessoas e a organização.” (RASCÃO, 2004, p.28).

Sistema: "conjunto de elementos unidos por alguma forma de interação ou interdependência." (SANDRONI, 1999, p.560). “As organizações são sistemas que funcionam como fluxos (processos), interagindo com o ambiente, e transformando-se para adaptar-se." (MAXIMIANO, 2002, p.451).

\footnotetext{
${ }^{42}$ No original: the process of quantifying the efficiency and effectiveness of action.
} 
Controle: processo pelo qual o comportamento de pessoas e coisas circunscreve-se aos objetivos das organizações (TANNENBAUM, 1968). Trata-se de um mecanismo projetado para minimizar riscos e incertezas, por adoção de padrões; associa-se também ao conceito de poder em uma dimensão política (SILVA, 2002, p.3).

Empreendedor: há diversos conceitos para empreendedor. Neste estudo, assumiu-se esse conceito como aquela pessoa que cria empresas, mobilizando recursos e modificando os arranjos econômicos pré-existentes (SCHUMPETER, 1982). Assim, consideram-se franqueador e franqueado como empreendedores.

Finalmente, neste trabalho, utilizar-se-á o termo "avaliação de desempenho" com o sentido de desempenho organizacional e não como desempenho das pessoas na organização, também frequiente na literatura acadêmica.

\subsection{Limitacões da pesquisa}

È possível fazer inferências válidas na população (neste estudo, franquias) somente se a amostra é representativa. Uma vez que não se tenha informações suficientes da população para comparar com a amostra, pode-se assegurar uma amostra não enviesada por uma seleção aleatória da população.

A pesquisa utilizou-se de uma amostra não probabilística, assim sujeita-se ao viés de não resposta e também ao viés nos respondentes.

De acordo com a amostra realizada, os resultados desse estudo, portanto, não podem ser generalizados; os resultados da pesquisa estão restritos a esta amostra.

Por tratar-se de um estudo exploratório, os resultados obtidos limitam-se à descrição do fenômeno estudado, mas não permitem generalizações.

A opção por este trabalho quantitativo buscou descrever um fenômeno amplo, no universo das franquias, no entanto, implica resultados preliminares.

As conclusões deste trabalho se possível devem-se confirmar por uma amostra probabilística. 


\section{RESULTADOS OBTIDOS E ANÁLISES}

\subsection{Resultado da pesquisa - caracterizacão dos respondentes}

Nesta parte, apresentam-se as respostas obtidas no questionário administrado, e suas possíveis conclusões. Do grupo de franqueadores convidados por e-mail para responder o questionário, obtiveram-se 65 respostas, e se desconsideraram dois questionários, devido a erros de preenchimento, restando assim 63 respondentes válidos. A tabela 9 apresenta algumas características descritivas das franquias que participaram da pesquisa.

Tabela 9 - Estatísticas descritivas da amostra.

\begin{tabular}{lrrrrr}
\hline & Média & Mediana & $\begin{array}{l}\text { Desvio } \\
\text { Padrão }\end{array}$ & Mínimo & Máximo \\
\hline $\begin{array}{l}\text { Número de lojas operando } \\
\text { com a marca. }\end{array}$ & 76,3 & 29 & 159,4 & 2 & 966 \\
$\begin{array}{l}\text { Número de franquias } \\
\text { operando com a marca. }\end{array}$ & 63,2 & 17 & 157,7 & 1 & 935 \\
$\begin{array}{l}\text { Número de lojas próprias } \\
\text { em operação. }\end{array}$ & 13,2 & 3 & 26,6 & 0 & 115 \\
$\begin{array}{l}\text { Início da operação com } \\
\text { franquias. (em anos) }\end{array}$ & 7,97 & 6 & 7,08 & 0 & 46 \\
$\begin{array}{l}\text { Investimento total para } \\
\text { abertura de loja padrão. } \\
\text { (em R\$) }\end{array}$ & 431178,6 & 150000 & 1389739 & 15000 & 800000 \\
$\begin{array}{l}\text { Tempo para recuperar o } \\
\text { investimento. (em meses) }\end{array}$ & 26,65 & 24 & 11,58 & 12 & 71 \\
\hline $\mathrm{N}=63$ franqueadores & & & & & \\
\hline
\end{tabular}

Os valores extremos presentes na amostra provocam o distanciamento entre a média e a mediana. Nesse caso, a mediana é um dado mais apropriado para sumarizar a amostra quanto a medidas de tendência central. A tabela 10 explicita o setor de atuação das empresas respondentes. 
Tabela 10 - Setores de atuação da amostra

\begin{tabular}{lrr}
\hline Setor & Freqüência & Percentual \\
\hline Fotografias, gráficas e sinalização & 0 & $0,0 \%$ \\
Construção & 1 & $1,6 \%$ \\
Cosméticos e perfumaria & 1 & $1,6 \%$ \\
Livrarias e papelaria & 1 & $1,6 \%$ \\
Móveis decorações e presentes & 1 & $1,6 \%$ \\
Automotivos & 1 & $1,6 \%$ \\
Outros & 1 & $1,6 \%$ \\
Assessórios e calçados & 2 & $3,2 \%$ \\
Hotelaria e turismo & 2 & $3,2 \%$ \\
Entretenimento & 2 & $3,2 \%$ \\
Limpeza e conservação & 2 & $3,2 \%$ \\
Comunicação, informática e eletrônicos & 3 & $4,8 \%$ \\
Escolas de idiomas & 4 & $6,5 \%$ \\
Serviços, negócios e conveniências. & 5 & $8,1 \%$ \\
Vestuário & 6 & $9,7 \%$ \\
Beleza, saúde e produtos naturais. & 8 & $12,9 \%$ \\
Educação e treinamento & 10 & $16,1 \%$ \\
Alimentação & 13 & $21,0 \%$ \\
Total & 63 & $100,0 \%$ \\
\hline
\end{tabular}

A Comparação da tabela 10 com a tabela 11, a seguir, relativa aos dados da $\mathrm{ABF}$, evidência que a amostra obtida é coerente com a distribuição por setores do cenário nacional.

Tabela 11 - Setores de atuação do mercado

Setor

Hotelaria e Turismo

Fotos, gráficas e sinalização.

Limpeza e conservação

Veículos

Informática e eletrônicos

Acessório e calçados

Móveis, decoração e presentes

Negócios, serviços e outros varejos.

Vestuário

Educação e treinamento

Esporte, saúde, beleza e lazer.

Alimentação
Percentual

$1,28 \%$

$1,58 \%$

$4,24 \%$

$4,44 \%$

$4,54 \%$

$5,43 \%$

$5,92 \%$

$10,46 \%$

$11,75 \%$

$14,12 \%$

$16,78 \%$

$19,45 \%$

Fonte: adaptado de ABF, 2007, disponível em versão digital.

Como o universo pesquisado são as franquias listadas pelo Guia completo de Franquias 2007, realizou-se a comparação da distribuição de setores obtidos com os dados da tabela 5. Ao se testar a representatividade da amostra quanto ao setor de atuação, não foi possível rejeitar a hipótese de semelhança entre a distribuição amostral e do universo, concluindo-se, pois, pela representatividade amostral $\left(\chi^{2}=18,236 ; p>0,10\right)$. 
As variáveis apresentam grande dispersão relativa, sendo o tempo de retorno o dado de menor dispersão. Além disso, apenas uma rede começou a operar há 46 anos; o início do restante deu-se entre 18 anos ou menos. Ressalta-se também que $13 \%$ da amostra, ou seja, oito redes de franquias, compõem-se por redes com mais de 100 lojas. Desse grupo, apenas três apresentam mais de 170 lojas, conforme a tabela 12.

Tabela 12 - Redes em número de lojas

\begin{tabular}{cl}
\hline Número de redes & Número de lojas na rede \\
\hline 47 & Até 50 lojas \\
8 & De 50 até 100 lojas \\
5 & De 100 até 170 lojas \\
1 & 450 lojas \\
1 & 750 lojas \\
1 & 935 lojas \\
\hline
\end{tabular}

O investimento de $\mathrm{R} \$ 150.000,00$ para abrir uma loja padrão refere-se a seis respondentes, considerado o valor mais frequiente de respostas (moda). Um investimento de até (e inclusive) $\mathrm{R} \$ 300.000,00$ refere-se a $87 \%$ dos respondentes.

Quase a totalidade (94\% dos casos) tem o retorno do investimento entre 12 e 36 meses. A pesquisa obteve apenas duas respostas de 71 meses de tempo de retorno do investimento, referentes a franquias do setor de hotelaria, e duas de 48 meses.

Grande parcela dos franqueadores (referentes à amostra) é paga por meio de royalty $(76,1 \%)$, mas não exclusivamente, a saber:

- 2 franquias são remuneradas também através de aluguéis;

- 34 franquias respondentes dizem remunerar só por royalty;

- 15 franquias respondentes dizem remunerar só por taxa fixa (aluguéis ou taxa independente do faturamento);

- 14 franquias dizem remunerar por royalty e taxa fixa.

A seguir, apresentam-se os resultados em relação à avaliação nas franquias estudadas. 


\subsection{Avaliacão em franquias - freqüências obtidas}

A maioria dos respondentes (62 dos 63) indicou realizar a avaliação de desempenho das unidades franqueadas. Não se pode considerar esse dado como representativo das franquias nacionais, pois é possível que, principalmente, as franquias interessadas em avaliação tenham respondido ao questionário.

Apesar do alto índice de franqueadores que afirmam realizar avaliação, deve-se questionar se pode-se considerá-la uma avaliação estruturada. 98\% dos franqueadores afirmam realizar avaliação das lojas franqueadas, logo é relevante notar que $11 \%$ dos respondentes não definem objetivos a serem atingidos pelas franquias, e 17\% não relacionam os resultados obtidos com os objetivos. Além disso, $21 \%$ não definem os dados coletados durante a avaliação. Dos franqueadores, $41 \%$ não constroem indicadores no processo de avaliação, e $10 \%$ não consideram a etapa de sugerir mudanças no processo de avaliação, entretanto $82 \%$ afirmam utilizar a avaliação para rever os objetivos. Mesmo que ocorra o processo de avaliação na maioria das franquias, em uma parcela o processo afasta-se do que propõe as teorias sobre avaliação, e está desestruturado. A tabela 13 sumariza as respostas obtidas na amostra sobre as etapas presentes no processo de avaliação.

Tabela 13 - Etapas existentes no processo de avaliação das franquias da amostra.

\begin{tabular}{lcccc}
\hline Etapas do processo de avaliação. & Ausente & Percentual & Presente & Percentual \\
\hline Definição da equipe responsável pela avaliação & 12 & $19,0 \%$ & 51 & $81,0 \%$ \\
Definição dos objetivos a serem atingidos & 7 & $11,1 \%$ & 56 & $88,9 \%$ \\
$\begin{array}{l}\text { Definição dos dados coletados } \\
\text { Definição das dimensões avaliadas (financeiro, }\end{array}$ & 13 & $20,6 \%$ & 50 & $79,4 \%$ \\
clientes, processos) & 16 & $25,4 \%$ & 47 & $74,6 \%$ \\
$\begin{array}{l}\text { Definição dos pesos e critérios para cada item } \\
\text { pesquisado }\end{array}$ & 24 & $38,1 \%$ & 39 & $61,9 \%$ \\
Construção de indicadores & 26 & $41,3 \%$ & 37 & $58,7 \%$ \\
Levantamento de dados. & 9 & $14,3 \%$ & 54 & $85,7 \%$ \\
Integração dos resultados nos módulos ou & & & & \\
dimensões. & 34 & $54,0 \%$ & 29 & $46,0 \%$ \\
Comparação dos resultados obtidos com esperados & & & & \\
e relatório final. & 11 & $17,5 \%$ & 52 & $82,5 \%$ \\
Sugestões de mudanças. & 6 & $9,5 \%$ & 57 & $90,5 \%$ \\
Punição em função do resultado medido. & 50 & $79,4 \%$ & 13 & $20,6 \%$ \\
Premiação em função do resultado medido. & 36 & $57,1 \%$ & 27 & $42,9 \%$ \\
Revisão dos objetivos. & 11 & $17,5 \%$ & 52 & $82,5 \%$ \\
Revisão do sistema de avaliação. & 30 & $47,6 \%$ & 33 & $52,4 \%$ \\
& & & & $\mathrm{~N}=63$ \\
\hline
\end{tabular}


Considerando como etapas necessárias para um processo de avaliação estruturado, a definição de objetivos e dados coletados, o levantamento de dados, a comparação dos resultados obtidos com esperados e a decorrente revisão dos objetivos, pode-se afirmar que 37 franqueadores (54\%) apresentam uma avaliação estruturada, pois contemplam todas essas etapas.

A pesquisa permitiu também verificar a relação entre avaliação das lojas próprias e das lojas franqueadas, ou seja, que partes do sistema avaliam-se. 13 dos respondentes operam apenas através do sistema de franquias, e não contam com lojas próprias; outras 12 redes possuem apenas uma loja própria, a loja padrão ou piloto. Das redes restantes, apenas 4, ou seja, 3,1\% não realizam avaliação das lojas próprias. Deve-se observar ainda que das 38 lojas que operam com ambos os modelos, 10 redes (26\%) utilizam um sistema de avaliação para as lojas próprias diferente do utilizado para as lojas franqueadas. O instrumento propôs uma pergunta com resposta dissertativa para essa questão, buscando compreender por que os sistemas seriam distintos, já que a padronização é uma das vantagens competitivas do franchise. Eis algumas respostas:

- "O trabalho nas lojas próprias é basicamente de supervisão das rotinas pré-estabelecidas e nas franquias é de consultoria, ou seja, convencimento dos franqueados." (franqueador da área de alimentação);

- "A gestão administrativa e financeira da franquia é totalmente independente do franqueador. Portanto, isso não é avaliado pelo franqueador, mas é avaliado nas unidades próprias.” (franqueador da área de ensino de idiomas);

- "A auditoria financeira é mais abrangente nas lojas próprias" (franqueador da área de alimentação);

Considera-se, portanto, que nessas franquias pode haver uma preocupação maior com controle do que com a avaliação de desempenho da rede. Em outras palavras, percebe-se que muitos franqueadores almejam o sucesso das franquias, mas se preocupam principalmente com sua manutenção dentro dos padrões da rede e com a vigilância de comportamentos oportunistas. Por outro lado, a avaliação da estratégia da rede e de seus resultados é mais importante nas lojas próprias. 
Com relação à periodicidade das avaliações, apresentam-se os dados obtidos da amostra na tabela 14. A maior parte dos franqueadores realiza avaliação com uma periodicidade máxima de 3 meses (64\%). É significativo que 13\% dos respondentes não realizem avaliação com periodicidade definida, o que também indica um sistema de avaliação pouco estruturado. 4 franqueadores não forneceram essa informação.

Tabela 14 - Periodicidade da avaliação

\begin{tabular}{lccc}
\hline Periodicidade & Freqüiência & Percentual & $\begin{array}{c}\text { Percentual } \\
\text { Válido }\end{array}$ \\
\hline Não há periodicidade definida & 8 & $13 \%$ & $14 \%$ \\
Diária & 1 & $2 \%$ & $2 \%$ \\
Mensal & 21 & $33 \%$ & $36 \%$ \\
Bimestral & 4 & $6 \%$ & $7 \%$ \\
Trimestral & 11 & $17 \%$ & $19 \%$ \\
Semestral & 10 & $16 \%$ & $17 \%$ \\
Anual & 4 & $6 \%$ & $7 \%$ \\
Não responderam & 4 & $6 \%$ & \\
Total & 63 & $100 \%$ & $100 \%(59)$ \\
\hline
\end{tabular}

Entre os objetivos propostos no trabalho, um é encontrar os módulos ou critérios avaliados pelos franqueadores e a relevância de cada um destes itens. Através do instrumento de pesquisas, propuseram-se diversos aspectos que poderiam ser avaliados pelos franqueadores. Trataram-se esses atributos como variáveis binárias nas análises posteriores.

Tabela 15 - Avaliação das dimensões financeira e vendas

\begin{tabular}{|c|c|c|c|}
\hline Dimensão & Itens avaliados & Freq. & Percentual \\
\hline \multirow{4}{*}{$\frac{\tilde{\pi}}{\tilde{D}}$} & Volume de produtos vendidos pela loja & 32 & $54 \%$ \\
\hline & Preenchimento dos pedidos (prazo, correção) & 28 & $47 \%$ \\
\hline & Volume de produtos vendidos para o franqueado & 27 & $46 \%$ \\
\hline & Giro de estoque do franqueado & 27 & $46 \%$ \\
\hline \multirow{7}{*}{ 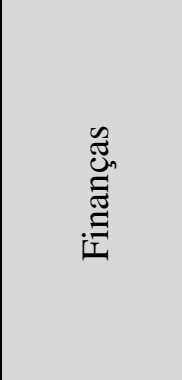 } & Faturamento da loja & 51 & $86 \%$ \\
\hline & Lucro da loja & 35 & $59 \%$ \\
\hline & Custos operacionais da loja & 34 & $58 \%$ \\
\hline & Despesas financeiras da loja & 22 & $37 \%$ \\
\hline & Despesas com impostos da loja & 19 & $32 \%$ \\
\hline & Outros aspectos financeiros & 19 & $32 \%$ \\
\hline & Retorno sobre ativos na loja & 8 & $14 \%$ \\
\hline
\end{tabular}

A tabela 15 apresenta os itens propostos e a freqüência de franqueadores que apontaram avaliar cada um destes, relativos às dimensões financeiras e de vendas. Novamente, 
desconsideraram-se 4 franqueadores para a construção dessa tabela. Como era de se esperar, o item mais avaliado dos aspectos financeiros propostos foi o faturamento da unidade: $86 \%$ dos respondentes, item quase indispensável para a cobrança de royalty ${ }^{43}$. Em seguida, $59 \%$ dos franqueadores monitoram o desempenho efetivo da loja, acompanhando o lucro e os custos financeiros das unidades. Uma parte significativa dos franqueadores acompanha também o volume de produtos vendidos para os fraqueados (46\%) e o volume de produtos vendidos pelos franqueados (56\%). Apenas 18 franqueadores (30\%) não acompanham nenhum desses 2 itens, relativos à venda de produtos. Desse grupo, 6 franquias são do setor de educação, outras 10 são prestadoras de serviço, não tendo no fornecimento de produtos seu principal escopo. Aproximadamente metade dos franqueadores está atenta aos 4 itens que compõem a dimensão vendas.

As tabelas 16 e 17 resumem as outras dimensões possivelmente avaliadas pelos franqueadores. A terceira dimensão proposta compõe-se por aspectos relativos à operação e manutenção da loja. Dos itens mais avaliados nessa dimensão, as condições de higiene e do espaço físico revelam uma preocupação com a imagem que a loja transmite e com as condições de trabalho da equipe. Como os negócios de franquia essencialmente se ligam ao varejo, é compreensível uma preocupação com esses itens.

A maior preocupação dos franqueadores aparece nos itens relativos à marca. $\mathrm{O}$ respeito aos padrões da marca é avaliado por 57 franqueadores, os quais afirmam verificar se não há desrespeito à marca. Esse comportamento ocorre de acordo com o esperado, pois a marca é o principal produto do franqueador. Também se avaliam aspectos relativos à imagem da marca; por exemplo, $86 \%$ dos franqueadores afirmam verificar as condições da fachada das unidades, e $81 \%$, as condições de higiene do ambiente.

Os aspectos relativos aos clientes estão presentes na maioria das avaliações realizadas. Todos os franqueadores avaliam ao menos um item relativo ao cliente, seja a fidelidade (75\%), seja a satisfação (75\%), seja a qualidade do atendimento (75\%). 30 franqueadores avaliam mudanças no perfil dos clientes, entretanto somente 20 franqueadores avaliam mudanças no entorno, e nenhum dos franqueadores verifica mudanças populacionais na região da loja.

\footnotetext{
${ }^{43}$ Algumas franqueadoras na área de treinamento operam sobre o sistema de royalty, cobrado sobre o número de alunos matriculados, e não sobre o faturamento ou resultado da unidade.
} 
A equipe do franqueado é um dos pontos mais relevantes nas avaliações. $92 \%$ dos franqueadores afirmam acompanhar a eficiência dos funcionários da loja e a qualidade de atendimento. Aparentemente, para os franqueadores a equipe do franqueado é um dos fatores chaves do sucesso da loja. Nota-se que esses itens são mais freqüentemente acompanhados do que os relacionados aos aspectos financeiros. Aproximadamente, 90\% dos franqueadores avaliam também o treinamento do franqueado e da equipe, conforme tabela 16.

Tabela 16 - Dimensões avaliadas (manutenção, marca, clientes, equipe)

\begin{tabular}{|c|c|c|c|}
\hline Dimensão & Itens presentes na avaliação da franquia & Freq. & Percentual \\
\hline \multirow{7}{*}{ 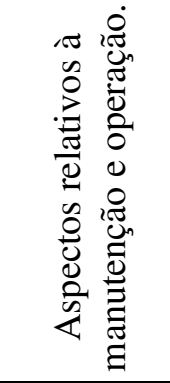 } & Uso do software de gestão & 49 & $83 \%$ \\
\hline & Condições de higiene na loja & 48 & $81 \%$ \\
\hline & Condições do espaço físico (manutenção) & 47 & $80 \%$ \\
\hline & Manutenção do maquinário/equipamento da loja. & 36 & $61 \%$ \\
\hline & Atualização tecnológica (máquinas, softwares) & 35 & $59 \%$ \\
\hline & Outros aspectos de infra-estrutura & 32 & $54 \%$ \\
\hline & Consumo de energia / água da loja & 17 & $29 \%$ \\
\hline \multirow{4}{*}{ 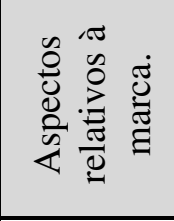 } & Respeito aos padrões da marca. & 57 & $97 \%$ \\
\hline & Condições da fachada/vitrine & 51 & $86 \%$ \\
\hline & Condições de higiene na loja & 48 & $81 \%$ \\
\hline & Participação da loja em ações sociais da rede & 29 & $49 \%$ \\
\hline \multirow{7}{*}{ 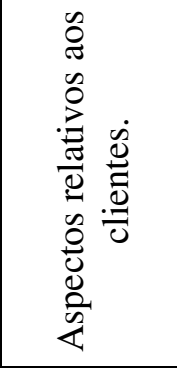 } & Satisfação do cliente daquela loja & 44 & $75 \%$ \\
\hline & Fidelização dos clientes da loja & 44 & $75 \%$ \\
\hline & Atendimento ao cliente na loja (tempo, pós-venda) & 44 & $75 \%$ \\
\hline & Mudanças na concorrência na região da loja & 33 & $56 \%$ \\
\hline & Perfil dos clientes da loja (renda, gênero) & 30 & $51 \%$ \\
\hline & Mudanças relevantes na região (obras, shoppings) & 20 & $34 \%$ \\
\hline & Mudanças populacionais na região (perfil, densidade) & 0 & $0 \%$ \\
\hline \multirow{7}{*}{ 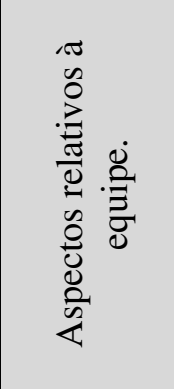 } & Eficiência dos funcionários da loja & 54 & $92 \%$ \\
\hline & Treinamento do pessoal operacional & 54 & $92 \%$ \\
\hline & Qualidade do atendimento na loja & 53 & $90 \%$ \\
\hline & Treinamento do franqueado/gestor/administrativo & 52 & $88 \%$ \\
\hline & Satisfação/motivação da equipe & 49 & $83 \%$ \\
\hline & Identificação da equipe da loja com os atributos da marca & 41 & $69 \%$ \\
\hline & Rotatividade dos funcionários & 37 & $63 \%$ \\
\hline
\end{tabular}

Os aspectos menos avaliados pelos franqueadores são os relativos à logística das operações, entretanto $85 \%$ dos franqueadores utilizam softwares de gestão para a avaliação, como se pode verificar na tabela 17 . Observa-se que esse item relaciona-se também à operação do franqueado, e não apenas à operação logística da rede. 
Tabela 17 - Dimensões avaliadas (logística, parcerias, inovação)

\begin{tabular}{|c|c|c|c|}
\hline Dimensões & Itens avaliados & Freq. & Percentual \\
\hline \multirow{6}{*}{ 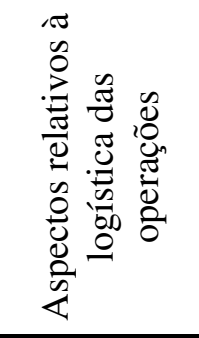 } & Uso dos softwares de gestão & 49 & $83 \%$ \\
\hline & Tempo de entrega dos produtos/insumos na loja & 25 & $42 \%$ \\
\hline & Recebimento dos produtos/insumos na loja & 25 & $42 \%$ \\
\hline & Preenchimento dos pedidos (prazo, correção) & 28 & $47 \%$ \\
\hline & Perdas de estoque (furtos, validade, acondicionamento) & 24 & $41 \%$ \\
\hline & Estoque (variabilidade de tamanhos, tipos, moda) & 30 & $51 \%$ \\
\hline \multirow{6}{*}{ 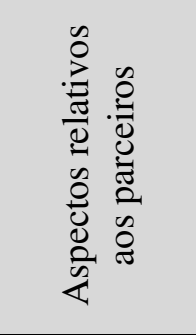 } & Participação da loja em ações promocionais da rede & 44 & $75 \%$ \\
\hline & Participação da loja em ações sociais da rede & 29 & $49 \%$ \\
\hline & Participação do franqueado nos grupos de franqueados & 33 & $56 \%$ \\
\hline & Processos Judiciais de terceiros contra a loja/franqueado & 16 & $27 \%$ \\
\hline & Relacionamento com o franqueador & 50 & $85 \%$ \\
\hline & Relacionamento do franqueado com fornecedores & 23 & $39 \%$ \\
\hline \multirow{4}{*}{ 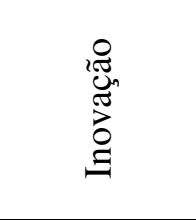 } & Avaliação das sugestões propostas pelo franqueado & 44 & $75 \%$ \\
\hline & Avaliação das inovações propostas à loja pelo franqueador & 41 & $69 \%$ \\
\hline & Avaliação das inovações criadas pelo franqueado & 39 & $66 \%$ \\
\hline & Atualização tecnológica (máquinas, softwares) & 35 & $59 \%$ \\
\hline
\end{tabular}

Quanto aos aspectos relativos às parcerias do negócio, o mais avaliado é o relacionamento com o próprio franqueador (85\%), e a participação da loja nas ações da rede (75\%), o que já era esperado. O relacionamento com os fornecedores é bem menos avaliado (39\%), assim como a relação com outros franqueados $(56 \%)$.

Quanto aos aspectos relativos a inovação, apenas 10\% dos franqueados não consideram esse fator em suas avaliações, seja em relação àquelas propostas pelo franqueado (69\%), seja em relação às propostas pelo franqueador (66\%). Deve-se observar que as mudanças propostas pelo franqueado, muitas vezes, são vistas não como inovações, mas sim como desvios do padrão da marca e, por isso, acompanhadas com rigor. 
De acordo com a maioria dos franqueadores, utilizam-se os dados coletados na construção de indicadores. A tabela 18 apresenta a frequiência de indicadores produzidos ${ }^{44}$.

Tabela 18 - Uso de indicadores de desempenho

\begin{tabular}{lcccc}
\hline & Para a loja franqueada & \multicolumn{2}{c}{ Para a rede toda } \\
\hline & Freqüência & Percentual. & Freqüência & Percentual. \\
\hline Não utiliza indicadores & 4 & $6 \%$ & 4 & $6 \%$ \\
Utiliza até 10 indicadores & 19 & $30 \%$ & 20 & $32 \%$ \\
Utiliza de 10 até 30 indicadores & 18 & $29 \%$ & 17 & $27 \%$ \\
Utiliza de 30 até 50 indicadores & 8 & $13 \%$ & 10 & $16 \%$ \\
Utiliza mais de 50 indicadores & 4 & $6 \%$ & 3 & $5 \%$ \\
Não respondeu & 10 & $16 \%$ & 9 & $14 \%$ \\
Total & 63 & $100 \%$ & 63 & $100 \%$ \\
\hline
\end{tabular}

Conforme visto na revisão bibliográfica, definir objetivos é uma das etapas fundamentais no processo de avaliação de desempenho (BOURNE et. al., 2000, p.757). As informações quanto a esse tema, fornecidas pelos franqueadores, estão disponíveis na tabela 19.

Tabela 19 - Objetivos

\begin{tabular}{lcccc}
\hline & \multicolumn{2}{c}{ Franqueadas } & \multicolumn{2}{c}{ Próprias** } \\
\hline Não define objetivos ou metas para as lojas & 3 & $5 \%$ & 0 & $0 \%$ \\
Define até 10 objetivos para as lojas & 40 & $73 \%$ & 28 & $65 \%$ \\
Define de 10 até 20 objetivos para as lojas & 5 & $9 \%$ & 10 & $23 \%$ \\
Define mais de 20 objetivos para as lojas & 7 & $13 \%$ & 5 & $12 \%$ \\
Define mais de 40 objetivos para as lojas & 0 & $0 \%$ & 0 & $0 \%$ \\
Total & 55 & $100 \%$ & 43 & $100 \%$ \\
$* *$ Apenas as franquias que têm lojas & & & & \\
próprias & & & & \\
\hline
\end{tabular}

A comparação entre as tabelas 19 e 18 revela um número de indicadores maior que o número de objetivos. 7 franqueadores informaram possuir um número distinto de objetivos para as franquias, daqueles para as lojas próprias, ocorrendo maior definição de objetivos para as lojas próprias. Considerando que a rede, a fim de obter todas as vantagens do ganho de escala, deveria operar de forma padronizada, é instigante que os franqueadores definam mais objetivos para as lojas próprias do que para as franqueadas. Além disso, 5 franqueadores que afirmam fazer avaliação, correspondendo a $9 \%$ dos respondentes, afirmam também que não verificam se os objetivos foram atingidos, tanto para as lojas próprias, quanto para as franqueadas.

\footnotetext{
${ }^{44}$ As respostas obtidas e apresentadas na tabela 15 estão em conflito com as respostas de outras perguntas.
} 
Tabela 20 - Participação do franqueado na definição dos objetivos e metas.

\begin{tabular}{lccc}
\hline & Frequiência & Percentual & $\begin{array}{c}\text { Percentual } \\
\text { válido }\end{array}$ \\
\hline Não ocorre a participação & 11 & $17 \%$ & $20 \%$ \\
Apenas para a loja própria do franqueado & 12 & $19 \%$ & $22 \%$ \\
Para todas as lojas franqueadas & 15 & $24 \%$ & $27 \%$ \\
Para toda a rede de lojas & 17 & $27 \%$ & $31 \%$ \\
Não responderam & 8 & $13 \%$ & - \\
Total & 63 & $100 \%$ & $100 \%$ \\
\hline
\end{tabular}

Na tabela 20, apresenta-se a distribuição de freqüências para a participação dos franqueados no processo de estabelecimento de objetivos e metas. De acordo com os franqueadores, $58 \%$ $(31 \%+27 \%)$ das redes aceitam a participação dos franqueados na definição dos objetivos para todas as lojas (ou ao menos para as franqueadas), coerentemente com as prescrições sobre sistemas de franquias vistas na revisão bibliográfica. Entretanto, dos 11 (17\%) franqueadores que não contam com o franqueado para essa fase (nem mesmo para a definição de objetivos da loja daquele franqueado), 7 franqueadores afirmam estabelecer objetivos para as lojas franqueadas.

Com relação à responsabilidade pela avaliação, as freqüências obtidas estão dispostas na tabela 21. O processo é realizado conjuntamente pelo franqueador e o franqueado na maior parte dos casos, totalizando $64 \%$ da amostra. Apenas um franqueador utiliza avaliação externa.

Tabela 21 - Execução da avaliação

\begin{tabular}{lccc}
\hline & Freqüência & Percentual & $\begin{array}{c}\text { Percentual. } \\
\text { Válidos }\end{array}$ \\
\hline Apenas o franqueador & 14 & $22 \%$ & $25 \%$ \\
Apenas o franqueado & 0 & $0 \%$ & $0 \%$ \\
O franqueador e o franqueado & 27 & $43 \%$ & $49 \%$ \\
Um avaliador externo à rede contratado & 1 & $2 \%$ & $2 \%$ \\
O franqueador, o franqueado, e um avaliador externo & 13 & $21 \%$ & $24 \%$ \\
Não responderam & 8 & $13 \%$ & - \\
Total & 63 & $100 \%$ & $100 \%$ \\
\hline
\end{tabular}

A Tabela 22 apresenta os dados sobre o envio dos resultados da avaliação para o franqueado. O fato de $9 \%$ dos franqueadores não enviarem o resultado da avaliação aos franqueados merece atenção, pois faz questionar qual o propósito da avaliação nesses casos. Contando com esses franqueadores, $42 \%$ não envia aos franqueados parâmetros para comparar o desempenho de sua loja com as outras unidades da rede. 
Tabela 22 - Envio do resultado da avaliação para o franqueado

\begin{tabular}{lccc}
\hline & Freqüiência & Percentual & $\begin{array}{c}\text { Percentual. } \\
\text { Válidos }\end{array}$ \\
\hline Não é enviado nenhum resultado de avaliação & 5 & $8 \%$ & $9 \%$ \\
Somente o da própria loja & 18 & $29 \%$ & $33 \%$ \\
O da própria loja e uma média das outras lojas & 16 & $25 \%$ & $29 \%$ \\
O resultado de todas as lojas franqueadas & 3 & $5 \%$ & $5 \%$ \\
O resultado de todas as lojas próprias & 0 & $0 \%$ & $0 \%$ \\
O resultado de todas as lojas próprias e franqueadas & 13 & $21 \%$ & $24 \%$ \\
Não responderam & 8 & $13 \%$ & - \\
Total & 63 & $100 \%$ & $100 \%$ \\
\hline
\end{tabular}

Este trabalho também buscou confirmar a existência de conflitos em decorrência da avaliação e suas razões. Além disso, utilizou-se uma pergunta dissertativa, a fim de obter um detalhamento dos possíveis conflitos. A tabela 23 resume as informações prestadas pelos franqueadores sobre a existência de conflitos.

Tabela 23 - Conflitos decorrentes da avaliação.

\begin{tabular}{lccc}
\hline & Freqüiência & Percentual & $\begin{array}{c}\text { Percentual } \\
\text { Válidos }\end{array}$ \\
\hline A avaliação gera conflitos importantes & 9 & $14 \%$ & $16 \%$ \\
A avaliação não gera conflitos importantes & 46 & $73 \%$ & $84 \%$ \\
Não responderam & 8 & $13 \%$ & - \\
Total & 63 & $100 \%$ & $100 \%$ \\
\hline
\end{tabular}

Os principais conflitos relatados foram:

- Discordância por parte do franqueado em relação aos objetivos propostos pelo franqueador para a loja;

- Desgastes no relacionamento franqueador e franqueado em função da indicação dos erros e problemas;

- O processo de avaliação demonstra lojas operando fora dos padrões (preço, marca, entre outros) e a necessidade de adequação produz conflito;

- Alguns franqueados sentem-se cobrados e não percebem a avaliação como algo positivo, que visa melhoria na rede;

- Discordância dos resultados e dos métodos usados na avaliação (neste caso, trata-se de redes que realizam punição ou premiação);

- Criação de justificativas para um resultado ruim, ao invés do ajuste necessário.

O trabalho verificou também os aspectos facilitadores e os aspectos que dificultam a avaliação de desempenho. Dos 63 respondentes, apenas 38 franqueadores forneceram essa informação. 
Obteve-se o índice apresentado pela somatória das freqüências de respostas, multiplicadas pelo peso de -3 até 3 , conforme tabela 24 :

Tabela 24 - Escala de respostas para os itens e peso considerado.

\begin{tabular}{|l|c|}
\hline Resposta & Peso \\
\hline Facilita Muito. & 3 \\
\hline Facilita. & 2 \\
\hline Facilita Pouco. & 1 \\
\hline Neutro para a avaliação. & -1 \\
\hline Atrapalha pouco. & -2 \\
\hline Atrapalha. & -3 \\
\hline Atrapalha muito a avaliação.
\end{tabular}

Apresenta-se, assim, a distribuição da quantidade de respostas na tabela 25 , ordenada dos aspectos que mais atrapalham para os que mais facilitam.

Tabela 25 - Aspectos que facilitam ou atrapalham a avaliação.

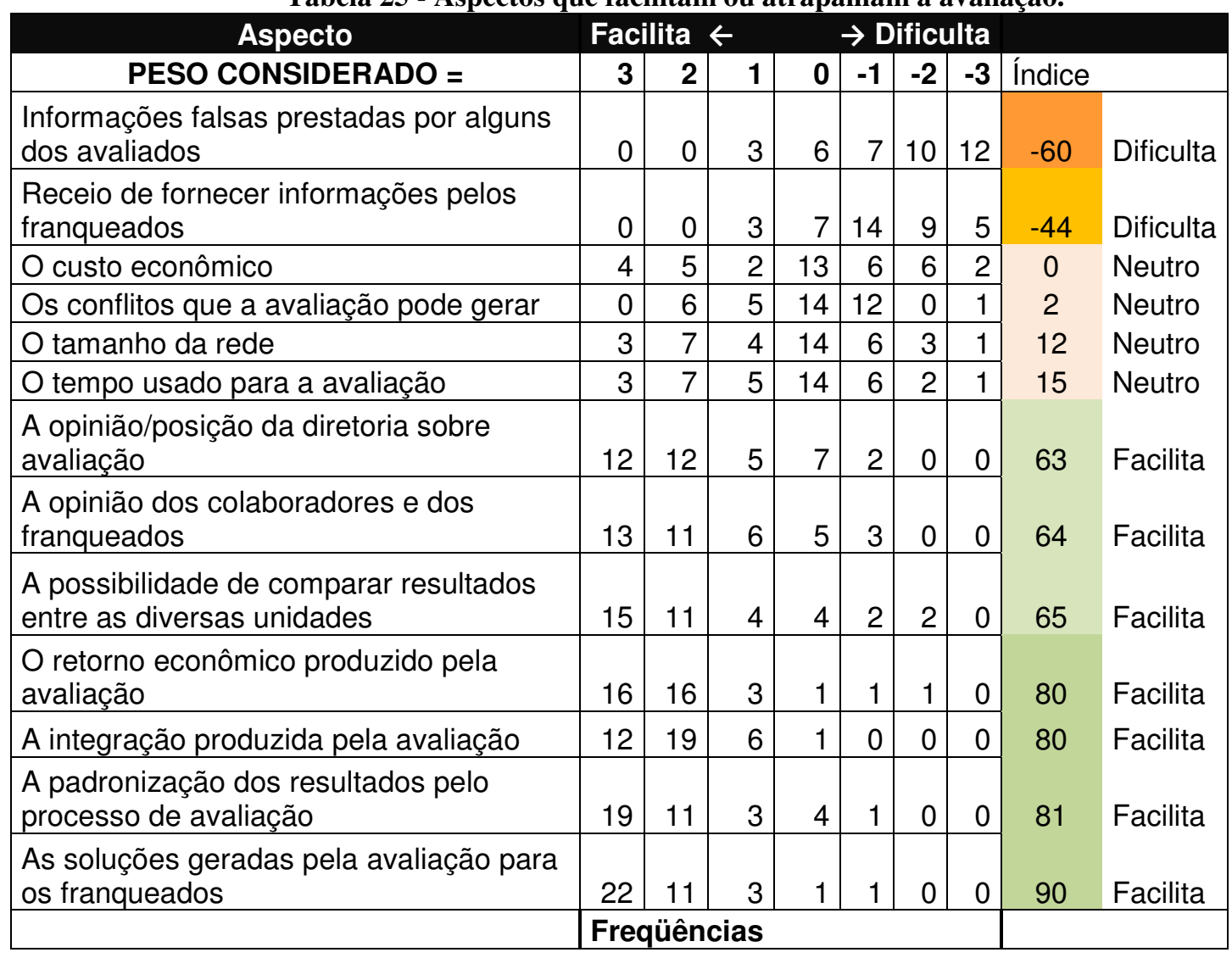

A seguir, analisam-se e se comparam os resultados obtidos com a revisão bibliográfica. 


\subsection{Observacões sobre os resultados relativos a freqüência de respostas.}

Com relação aos dados apresentados, a primeira constatação é haver um processo intenso de avaliação realizado pelos franqueadores, com um elevado grau de complexidade, pela maior parte deles (aqueles que responderam a pesquisa).

A análise das respostas permite inquirir o propósito da avaliação de desempenho nas franquias, da forma como tem sido realizada. De acordo com Prahalad e Krishnan (2002), prover informações sobre desempenho não é suficiente para promover o resultado dos negócios, sendo o ponto crítico compreender como se utilizam essas informações. Os franqueadores dessa amostra, em sua quase totalidade, afirmam avaliar os resultados das unidades; esse processo é realizado por $41 \%$ deles, ignorando estágios fundamentais em um processo de avaliação. Os diferentes modelos de avaliação revisados na bibliografia citam a necessidade de definição de objetivos, definição dos dados a serem coletados, obtenção dos dados e, finalmente, a comparação dos resultados obtidos com os esperados. Bourne et. al. (2000, p.757) resumem que um processo de avaliação de desempenho organizacional deve passar necessariamente pelas seguintes etapas e sub-etapas:

- Desenho das medidas de desempenho:

- Identificar os objetivos principais (com ênfase na estratégia);

- Desenhar os indicadores que mediram a adequação aos objetivos;

- Implantação das medidas de desempenho:

- Estabelecer as rotinas envolvidas no processo de obtenção regular de dados;

- Coletar os dados;

- Analisar os dados coletados;

- O uso das medidas de desempenho:

- Medir a aplicação da estratégia conforme planejada;

- Questionar as premissas e reavaliar a estratégia;

Contrapondo-se essas etapas aos dados obtidos dos respondentes, visíveis na tabela 13, indaga-se como o processo de avaliação dos franqueadores, para uma parcela significativa dos franqueadores, está mais próximo de um processo de controle das atividades dos franqueados, do que de um processo de avaliação voltado ao aperfeiçoamento da estratégia. 
A amostra aproxima-se da distribuição do mercado, e é estatisticamente representativa do universo utilizado quanto ao setor de atuação, como mostra a comparação entre a tabela 5, que traz a população ou universo, a tabela 10, que trata da amostra, e a tabela 11, que trata dos dados de mercado da ABF. Observa-se que, nos dados da ABF, reúnem-se os setores de beleza e saúde com entretenimento. Uma distribuição da amostra, semelhante àquela existente no mercado, evidência que o processo de avaliação interessa aos setores com intensidade parecida, ou talvez poderia se obter uma menor quantidade de respostas de algum setor, devido ao viés de não-resposta por aqueles franqueadores que não fazem, nem tem interesse em realizar avaliação. No item 4.4, aprofunda-se essa questão.

As tabelas 15, 16 e 17 discutem os módulos ou dimensões que os franqueadores podem avaliar. Segundo a revisão bibliográfica (CHERTO et. al, 2006, p.255), nas franquias de terceira geração, os itens propostos no estudo são normalmente acompanhados pela figura do consultor de campo. Realmente, boa parte deles é avaliada por mais de metade dos franqueadores, contemplando-se as diversas dimensões na avaliação, como recomenda a literatura (CHERTO et. al, 2006, p.270).

De acordo com Kennerley e Nelly (2003), desde o começo do século XX até a década de 90, o foco da avaliação de desempenho foi principalmente no retorno sobre investimento e em outros aspectos financeiros. O presente estudo revela o contrário, ou seja, uma ênfase maior em aspectos operacionais, da marca e relativos à equipe, do que em aspectos financeiros ou de vendas. É natural indagar-se se essa diferença ocorre devido aos franqueadores estarem cientes das recomendações da literatura sobre as avaliações. Uma explicação alternativa, e possivelmente a mais provável, vincula-se ao objetivo da avaliação dos franqueados pelo franqueador. Certamente, o franqueador preocupa-se com o resultado econômico do franqueado, em especial se o recebe através de royalty relativo ao faturamento e não por taxa fixa. Entretanto, o resultado econômico do franqueador relaciona-se principalmente ao valor da marca. Uma marca mais valorizada permite aumentar o número de franqueados, cobrar uma taxa de royalty maior, ou ainda aumentar o custo da taxa de franquia.

De acordo com Ambler et. al. (2002), o valor da marca vincula-se à qualidade dos serviços prestados. No caso, serviços prestados pelos franqueados e por suas equipes. Coerentemente com essa suposição, os aspectos mais avaliados pelos franqueadores são aqueles relativos aos padrões da marca (97\%), e a percepção mais básica possível da loja como parte de uma cadeia 
com marca forte, visível, por exemplo, nas condições de sua fachada. Também Ambler et. al. (ibid.), informam que, se o consumidor atribui à marca uma série de atributos, é somente na prestação do serviço ou na compra e no uso de um produto que ele tangibiliza esses atributos, consolidando-os. Novamente no caso do franchise, o franqueador e sua equipe são os responsáveis por essas fases, justificando por si a alta preocupação (por volta de 90\%) em avaliar os serviços prestados pelos franqueados e suas equipes.

Pode-se sugerir, portanto, que um sistema de avaliação para o franqueador deve contemplar necessariamente indicadores relacionados ao valor da marca. É possível afirmar que, para a maioria dos franqueadores, a valorização da marca é um dos objetivos principais, uma das diretrizes estratégicas que deve ser adotada, como uma decorrência lógica da busca por maior lucratividade e sustentabilidade.

Os fatores menos acompanhados pelos franqueadores são os itens relativos à logística e aos fornecedores. Em média, 45\% dos franqueadores avaliam itens, como perdas de produtos, prazos de entrega de produtos ou de insumos nas lojas e preenchimentos corretos de pedidos. Essa situação é curiosa, pois estes são pontos críticos do sistema de franquias de responsabilidade do franqueador. Atrasos na entrega podem gerar prejuízos significativos ao franqueado, por exemplo, em um dia das mães, ou no período de Natal, quando a ausência de produtos compromete significativamente o resultado da loja. Essa questão reforça a sensação de que os franqueadores preocupam-se mais com o modo de operação dos franqueados, do que com o sistema franqueador e franqueados. A ênfase da avaliação localiza-se em restrição e controle do franqueado, e não em aperfeiçoamento da rede.

Além disso, o uso dos softwares de gestão por $85 \%$ dos franqueadores evidenciam como o processo de avaliação tem sido facilitado pelo avanço da informática. Finalmente, o alto índice de franqueadores que avalia a equipe do franqueado e os aspectos relativos a treinamento evidenciam a importância do padrão de atendimento e da padronização no sistema de franquias. O raciocínio inverso também é válido; é provável que muitos franqueadores avaliem esses pontos, já que, dessa forma, direcionam o comportamento e a atenção do franqueado aos aspectos chaves do franchise. As parcerias são também menos avaliadas, em relação aos outros índices, o que revela uma possível oportunidade para os franqueadores que procuram vantagem competitiva. 
A construção de indicadores, coerentemente com as prescrições dos modelos atuais de avaliação de desempenho, também é comum nas redes, apontada por mais da metade dos franqueadores.

A boa relação entre franqueador e franqueado é chave para o sucesso de um processo de avaliação de uma parte pela outra. Há, nos dados das tabelas 22 e 23, diversos indícios de atitudes realizadas por uma pequena parcela dos franqueadores que podem sinalizar dificuldades nessa relação. Primeiramente, é curioso que poucos franqueadores informem que há conflitos decorrentes do processo de avaliação (apenas 16\%), mas que $17 \%$ dos franqueadores estabeleçam objetivos para os franqueados sem considerar a participação destes no processo. Os franqueadores que informam a existência de conflitos não são os mesmos que isolam os franqueados do processo de definição de objetivos. Além disso, apenas $30 \%$ dos franqueadores sentem-se tranqüilos em repassar aos franqueados o resultado da rede como um todo, o que revela alguma desconfiança por parte dos franqueadores. Independente da vontade do franqueador, revelar o balanço da empresa franqueadora e sua situação financeira é obrigatório pela lei de franquias para os novos franqueados (BRASIL, 2007). Sendo assim, questiona-se o medo do franqueador de passar informações aos franqueados antigos.

Em relação aos aspectos que facilitam ou dificultam a avaliação, expostos na tabela 25, é possível inferir que o maior receio dos franqueadores e a principal dificuldade estão no risco dos franqueados prestarem informações falsas, seguido do receio dos franqueados em fornecer informação aos franqueadores. Esses dois aspectos reforçam que estabelecer uma sólida relação de parceria com os franqueados, e apresentar a eles os resultados efetivos do processo são dois comportamentos muito importantes para conseguir implementar e gerir com mais facilidade uma avaliação de desempenho na rede. Provavelmente, se o foco dos franqueadores fosse maior em avaliar e comunicar, e menor em controlar os comportamentos e resultados dos franqueados, esses aspectos teriam menor influência, pois os franqueados veriam os instrumentos de avaliação como aliados para seu desempenho, diminuindo o risco de conflito com os franqueados. Recorda-se que a percepção pelo franqueado de boa comunicação com o franqueador associa-se fortemente a um desejo dos franqueados de permanecerem na rede de franquias, mais do que um bom sistema de treinamento ou o fornecimento de instruções gerenciais. (CHIOU, HSIEH e YANG, 2004, p.32-33). 
A preocupação em manter um bom relacionamento com o franqueado explica por que, de acordo com o exposto na tabela 13,43\% dos franqueadores premiam os franqueados em função do resultado medido, mas apenas $20 \%$ punem-nos. A punição, em geral, é uma carta de advertência, enviada ao franqueado, sinalizando que algum dos itens medidos precisa melhorar, uma peça importante juridicamente caso o franqueador resolva romper o contrato com o franqueado.

Ainda da tabela 25, percebe-se que aspectos restritivos, como custo, tempo e tamanho da rede, são fatores neutros na visão dos franqueadores. Aparentemente, percebe-se bem a relação investimento e retorno, ao proceder uma avaliação dos franqueados, já que esses aspectos são neutros, mas se consideram os resultados obtidos no processo aspectos muito positivos (resultados econômicos, padronização e soluções para a rede). Observa-se que os recursos necessários para se estabelecer um sistema de avaliação são relativamente baixos, para uma empresa do porte dos franqueadores, e assim se percebem facilmente mais vantagens do que desvantagens.

A possibilidade de se compararem resultados é um aspecto facilitador para o uso das avaliações, na resposta da maior parte dos franqueadores. Esse aspecto de comparação explica por que encara-se o item "os conflitos" positivamente por somente alguns franqueadores, e de maneira neutra pela maioria. Segundo alguns franqueadores, a comparação de resultados gera uma concorrência entre os franqueados e os obriga a rever os comportamentos e posições adotadas. A franqueadora da Bit Company acrescentou que o processo resultante da avaliação é, aproximadamente, o seguinte: o franqueado que teve um desempenho ruim inicialmente reage à avaliação apresentando motivos externos para o melhor desempenho de outras unidades (um ponto melhor, por exemplo), mas após algum tempo, percebe que unidades em situação semelhante a dele tiveram desempenho melhor, e passa a agir com mais atenção, seja no processo de vendas, seja na operação da unidade.

Considerou-se a padronização dos resultados um dos aspectos que mais facilita a avaliação. Numa rede de franquias, a padronização de marca, loja, serviço e produtos é um dos aspectos fundamentais ao bom desempenho da rede (CHERTO, 2006). Dessa forma, fica claro que as avaliações são muito importantes para se estabelecer e se manter o padrão das unidades franqueadas, por ser uma ferramenta que traz ainda mais esse benefício ao franqueador, além dos tradicionalmente listados na bibliografia sobre avaliação. 


\subsection{Resultados obtidos e observacões com relação aos setores de atuacão.}

Apenas como caráter exploratório da pesquisa, realizou-se a análise das freqüências obtidas por setor de atuação, apesar do tamanho da amostra.

Percebe-se que alguns dos aspectos avaliados são mais comuns em alguns setores, o que não é surpreendente em função da atividade exercida. Se, na amostra, apenas $81 \%$ dos franqueadores verificam as condições de higiene, no setor de alimentação, todos os franqueadores acompanham esse item. Também é maior o número de franqueadores (82\%) desse setor que verificam o estado de máquinas e equipamentos, em relação ao resultado total da amostra (60\%). Entretanto, há algumas possíveis discussões quanto aos setores que não se relacionam apenas a detalhes operacionais específicos. Somente se compararam os 6 setores listados na tabela 26 , visto que os outros doze setores contavam com um máximo de 3 franquias respondentes, conduzindo a uma baixa representatividade dos dados. A Tabela 26 apresenta as frequiências relativas de utilização dos itens propostos dentro dos módulos financeiros e de vendas no sistema de avaliação da franquia por setores.

Tabela 26 - Avaliação dos módulos (Financeiro e venda) por setor

\begin{tabular}{|c|c|c|}
\hline Setor * & $\begin{array}{l}\text { Freqüência rel. } \\
\text { dos itens de } \\
\text { vendas sugeridos }\end{array}$ & $\begin{array}{l}\text { Freqüência rel. dos } \\
\text { itens financeiros } \\
\text { sugeridos }\end{array}$ \\
\hline Educação e treinamento (9 redes) & 8 em $36(22 \%) * *$ & 15 em $63(23 \%)$ \\
\hline Beleza, saúde e produtos naturais. ( 8 redes) & 13 em $32(40 \%)$ & 19 em $56(34 \%)$ \\
\hline Vestuário (6 redes) & 13 em $24(54 \%)$ & 15 em $42(36 \%)$ \\
\hline Serviços, negócios e conveniências. (5 redes) & 8 em $20(40 \%)$ & 16 em $35(46 \%)$ \\
\hline Escolas de idiomas (4 redes) & 9 em $16(56 \%)$ & 15 em $28(53 \%)$ \\
\hline Alimentação (11 redes) & 35 em $44(80 \%)$ & 53 em $77(69 \%)$ \\
\hline Media para todos os setores & 115 em $236(49 \%)$ & 188 em $413(45 \%)$ \\
\hline \multicolumn{3}{|c|}{$\begin{array}{l}* \text { Apenas dos setores com mais de quatro franqueadores respondentes. } \\
\text { ** Há } 9 \text { redes neste setor. Se todas acompanhassem todos os } 4 \text { itens relativos a vendas, haveria } \\
36 \text { respostas afirmativas. }\end{array}$} \\
\hline
\end{tabular}

Percebe-se na tabela 26 que o acompanhamento de aspectos financeiros e de vendas, como lucratividade, retorno sobre ativos, volume de produtos vendidos, giro de estoque, entre outros, é mais freqüente em alguns setores do que em outros. Enquanto o franqueador do setor 
de alimentação acompanha $69 \%$ dos itens financeiros propostos em média, no setor de educação e treinamento, o franqueador médio acompanha apenas $23 \%$ dos itens. Portanto, no setor de alimentos, verificam-se três vezes mais os itens financeiros do que no setor de ensino.

Considerando os itens relativos a vendas, a desproporção é ainda mais alta. Ainda mais relevante é o fato de que no setor de ensino de idiomas, os franqueadores acompanhem 53\% dos itens financeiros, e $56 \%$ dos relativos às vendas. É uma decorrência natural indagar as razões por que franqueadores em áreas com atividades semelhantes aos das escolas de idioma, como cursos preparatórios para concursos, cursos profissionalizantes, ou escolas de informática, estejam tão menos preocupados com o desempenho financeiro dos franqueados. A relação entre os itens verificados é da ordem de 130\% superior para as escolas de idioma.

Qual a razão para essa diferença? A tabela 27, adaptada do Guia Oficial de Franquias 2008 da ABF, talvez sinalize a explicação para essas discrepâncias.

Tabela 27 - Números de redes por setor.

\begin{tabular}{|c|c|c|c|}
\hline & Ano & 2006 & 2007 \\
\hline Vestuário & & 119 & 131 \\
\hline Negócios, Serviços e outros Varejos & & 106 & 135 \\
\hline Educação e Treinamento & & 143 & 160 \\
\hline Beleza, Saúde, Esporte e Lazer & & 170 & 212 \\
\hline Alimentação & & 197 & 241 \\
\hline Escolas de Idioma & & ND & ND \\
\hline \multicolumn{4}{|l|}{ ND = Não disponível } \\
\hline
\end{tabular}

Devido à inexistência de informações relativas às escolas de idiomas na tabela da Associação Brasileira de Franchising, consideradas conjuntamente com as redes de educação e treinamento, a relação não fica tão clara, mas é fácil perceber que quanto maior o número de redes, maior o número de aspectos financeiros acompanhados, exceto no caso das franquias do setor Beleza, saúde, esporte e lazer. Se considerado o setor de escolas de idioma um dos mais consolidados do país, setor no qual as primeiras franquias brasileiras (Yázigi e Escolas Fisk) estabeleceram-se, talvez a relação fique mais evidente. O Guia Completo de Franquias (INSTITUTO FRANCHISE, 2007, p.88-104) lista 88 franqueadores da área de ensino e treinamento. Destes, mais da metade é formada por franqueadores da área de ensino de idiomas, conforme tabela 28, evidenciando da saturação do setor, em comparação com os outros tipos de franquias de ensino. 
Tabela 28 - Segmentação do setor de ensino e educação

\begin{tabular}{lc}
\hline Descrição & Franqueadores \\
\hline Escola de Futebol & 1 \\
Sistema de ensino educação Infantil & 2 \\
Ensino de artes & 2 \\
Sistema de ensino fundamental & 3 \\
Reforço escolar & 3 \\
Preparação para Concursos e Direito & 4 \\
Capacitação - profissionalizante & 9 \\
Ensino de Informática & 18 \\
Ensino de idiomas & 46 \\
\hline Fonte: Elaborado pelo autor a partir de dados extraídos do \\
INSTITUTO FRANCHISE (2007).
\end{tabular}

Assim, supõe-se que os setores de alta competitividade apresentem uma maior preocupação com a avaliação de aspectos financeiros ou de vendas; contudo, será que essa relação permanece considerando todos os módulos propostos?

A tabela 29 relaciona o acompanhamento de todos os itens propostos na pesquisa, segmentados por setores. Nesse caso, a relação é ainda mais evidente.

Tabela 29 - Freqüência de acompanhamento dos itens propostos, por setores de atuação.

\begin{tabular}{|l|c|c|c|c|c|}
\hline \multicolumn{2}{|c}{ Setores } & N & Total & Máximo $\begin{array}{c}\text { Relação } \\
\text { Percentual }\end{array}$ & $\begin{array}{c}\text { Número } \\
\text { de redes }\end{array}$ \\
\hline Educação e treinamento & 9 & 188 & 423 & $\mathbf{4 5 \%}$ & ND \\
\hline Vestuário & 6 & 147 & 282 & $\mathbf{5 2 \%}$ & $\mathbf{1 3 1}$ \\
\hline Serviços e conveniências & 5 & 129 & 235 & $\mathbf{5 5 \%}$ & $\mathbf{1 3 5}$ \\
\hline Beleza e saúde & 8 & 225 & 376 & $\mathbf{6 0 \%}$ & $\mathbf{2 1 2}$ \\
\hline Escolas de idioma & 4 & 112 & 188 & $\mathbf{6 0 \%}$ & ND \\
\hline Alimentação & 11 & 398 & 517 & $\mathbf{7 7 \%}$ & $\mathbf{2 4 1}$ \\
\hline $\begin{array}{l}\text { N = Número de redes que respondeu a pesquisa no setor } \\
\text { Total = Número de itens avaliados entre os 47 propostos na questão 32 (no setor) }\end{array}$ \\
Máximo = Número máximo de itens avaliados que poderia ser atingido = N*47
\end{tabular}

Quanto maior o número de redes de um setor, mais competitivo este é, e maior a intensidade de aspectos verificados pelos franqueadores. As relações de causalidade são difíceis de se provarem, em especial nos estudos das ciências sociais, mas se apresenta um indício no sentido de uma formulação simples, sugerida para estudos futuros: maior competição entre as organizações, maior a intensidade de auto-avaliação. 


\subsection{Aprofundamento estatístico dos dados.}

Além da análise de frequiências apresentada anteriormente, também realizou-se um estudo estatístico dos dados, indicado a seguir. Hourneaux Jr., Cunha e Corrêa, (2004, p.23) afirmam ser importante adaptar o sistema de avaliação à organização e à sua realidade, assim, questiona-se por que diferentes realidades organizacionais, que tenham em comum a operação dentro do sistema de franquias, apresentam diferentes sistemas de avaliação em função de suas singularidades.

\subsubsection{Variáveis utilizadas e tratamento dos dados}

Conforme a metodologia, especificamente o item 3.5 relativo às definições, o presente estudo utiliza diversas variáveis qualitativas, classificáveis em nominais ou ordinais e também variáveis quantitativas intervalares, obtidas por pesquisa survey junto aos franqueadores. Além dessas variáveis obtidas diretamente, também elaborou-se um índice para cada grupo de variáveis nominais, relativas à definição das etapas de avaliação e às dimensões avaliadas pelos franqueadores: vendas, finanças, imagem da marca, operações, marketing, gestão de pessoal, logística, relacionamento com franqueador e parceiros e inovação, disponíveis nas tabelas 6 e 7 (pg.79). O índice obtido através do número total de respostas afirmativas por respondente é uma variável ordinal (de contagem).

No estudo, realizou-se um aprofundamento estatístico, considerando as diversas variáveis e as questões levantadas ao longo da revisão bibliográfica. As variáveis sofreram um tratamento estatístico diferenciado, em função de sua tipologia:

- para variáveis nominais e ordinais, estimou-se freqüência de respostas, percentual e percentual acumulado, conforme visto nos itens anteriores;

- para variáveis nominais, efetuou-se a Prova do Qui-Quadrado ou Prova de Fisher, que testa se as variáveis, duas a duas, são independentes (ou não associadas), ou seja, se dois grupos diferem em relação a determinada característica;

- para variáveis ordinais, procedeu-se à Prova de Kolmogorov-Smirnov, que compara duas amostras quanto à sua distribuição;

- para variáveis com mensuração intervalar ou variáveis contínuas discretas (variáveis de contagem), estimou-se a média, mediana, moda, máximo e mínimo, desvio-padrão, 
coeficiente de variação; para se compararem duas amostras em relação a estas (cada uma individualmente) aplicou-se a Prova de Mann-Whitney, que compara a distribuição de duas amostras; alternativa à prova t-Student, quando se deseja evitar suposições necessárias.

Realizaram as provas estatísticas no nível de significância de $\alpha=0,05$. Recorda-se que: "a hipótese nula, chamada $\mathrm{H} 0$, contém sempre uma igualdade, e sobre a qual se procura obter evidências para rejeitá-la" (CRESWELL, 2007). O nível de significância $(\alpha)$ representa a probabilidade (ou risco) de se incorrer no erro de rejeitar H0, quando essa hipótese é de fato verdadeira. (BUSSAB e MORETTIN, 1987, p.241)

O nível descritivo ou p ( $p$-value, em inglês) denota a probabilidade de ocorrência de eventos tão ou mais extremos do que o observado, considerando que H0 é verdadeiro. Assim, p baixo (menor ou igual ao nível de significância) indica que seria pouco provável observar determinado resultado, se $\mathrm{H} 0$ fosse verdadeiro. Se $\mathrm{p}>\alpha$ (nível de significância), então tomamos a decisão de não rejeitar H0.

\subsubsection{Hipóteses formuladas}

Formularam-se algumas hipóteses a partir da revisão bibliográfica, buscando atingir resultados comparativos, mesmo sendo este um estudo exploratório. A primeira hipótese formulada diz respeito à forma de remuneração do franqueador, se por royalty ou por taxa fixa. Se o franqueador é remunerado por royalty em função do resultado do franqueado, espera-se que ele se comprometa mais com o desempenho do franqueado, havendo necessidade de uma melhor avaliação deste.

Procedeu-se, portanto, à formulação de hipóteses nulas, a forma mais tradicional de redigir hipóteses (CRESWELL, 2007, p121):

$\mathrm{H} 1_{(1)}$ - Os franqueadores remunerados por royalty tendem a exercer avaliações consistentes e periódicas em suas franquias, mais do que os franqueadores que recebem por taxa fixa. $\mathrm{HO}_{(1)}$ - Não há diferença entre os grupos de franqueadores remunerados por royalty ou taxa fixa, no processo de avaliação que executam nos franqueados. 
A segunda hipótese formulada refere-se à clareza de objetivos e aos propósitos da avaliação do franqueador sobre o franqueado:

$\mathrm{H} 1_{(2)}$ - Os franqueadores que definem objetivos para suas lojas franqueadas e acompanham a realização desses objetivos tendem a ter uma estrutura de avaliação mais consistente, maior do que aqueles que não têm tanto foco nos objetivos.

$\mathrm{H}_{(2)}$ - Não há diferença entre os grupos de franqueadores que definem objetivos para as lojas franqueadas e acompanham a realização desses objetivos, e aqueles que não o fazem quanto ao processo de avaliação que executam nos franqueados.

A terceira hipótese formulada diz respeito ao tamanho da rede de lojas. É natural imaginar que o tamanho da rede influencia a construção do processo de avaliação, e que quanto maior a rede, mais estruturada é a avaliação realizada.

$\mathrm{H} 1_{(3)}$ - Quanto maior a rede de franquias, mais consistente o sistema de avaliação.

$\mathrm{H}_{(3)}$ - Não há diferença entre as redes de franquias com maior e menor número de lojas, quanto ao processo de avaliação que executam os franqueadores nos franqueados.

Finalmente, formulou-se uma quarta hipótese no mesmo sentido da anterior, que relaciona a idade das franquias à avaliação. Também é possível supor que para diferentes idades de franquia, a avaliação realizada seja diferente.

$\mathrm{H} 1_{(4)}-$ Em franquias novas ou antigas, a avaliação efetuada é diferente.

$\mathrm{HO}_{(4)}$ - Não há diferença entre as redes de franquias com mais tempo em atuação no franchise quanto ao processo de avaliação que executam os franqueadores nos franqueados.

Além destas hipóteses, posteriormente foram propostas outras buscando verificar a dependência entre os diferentes agrupamentos de franqueadores. Estas hipóteses estão disponíveis no item 4.5.4 


\subsubsection{Resultados obtidos para as hipóteses formuladas}

Realizaram-se alguns procedimentos, a fim de se verificarem as hipóteses formuladas. Para responder a primeira hipótese, classificou-se um grupo de franqueadores como remunerados através de royalty, e outro grupo remunerado exclusivamente através de taxa fixa.

\subsubsection{Processos e resultados sobre a Hipótese 1 (1).}

Em 40 variáveis (etapas ou itens de avaliação), os franqueadores que são remunerados por taxa fixa apresentaram maior proporção de presença do que os franqueadores que recebem por Royalty, contrariando a hipótese da pesquisa, e portanto não havendo razão para realização de prova estatística. Três destes itens são casos mais contundentes, descritos a seguir.

Pode-se afirmar que a remuneração de franqueadores através de taxa fixa está, relativamente mais presente na etapa de definição dos módulos do que aqueles que são remunerados por royalty, (93,3\% ante $68,8 \%$, respectivamente, quadro 1 ), o contrário do que seria esperado pela hipótese 1. Portanto, como a realidade se configurou contrária à hipótese original, nem é necessário a realização do teste.

Quadro 1 - Royalty e Definição das dimensões

\begin{tabular}{|l|r|r|r|r|}
\hline & & \multicolumn{2}{|c|}{$\begin{array}{c}\text { 10. Como o franqueador é } \\
\text { remunerado: royalties (porcentagem } \\
\text { do faturamento ou do resultado). }\end{array}$} & Total \\
\hline Variável & & Não & Sim & \\
\hline 17. Entre as etapas do processo de & Não & 1 & 15 & 16 \\
avaliação, ocorre a definição das dimensões & & $6,7 \%$ & $31,3 \%$ & $25,4 \%$ \\
ou módulos a serem estudadas. (financeiro, $\quad$ Sim & & 14 & 33 & 47 \\
recursos humanos, clientes) & & $93,3 \%$ & $74,6 \%$ \\
Total & & 15 & $68,8 \%$ \\
\hline
\end{tabular}

A comparação entre os franqueadores remunerados exclusivamente por taxa fixa, e os franqueadores remunerados por royalty, através do teste estatístico (unicaudal), apresentou associação com a presença da etapa de premiação no processo de avaliação, visível no Quadro $2 \operatorname{com} \chi^{2}=4,20$ e $\mathrm{p}=0,04$ quem cobra por royalty, proporcionalmente premia mais. Os franqueadores que cobram royalty variável premiam em $50 \%$ dos casos, enquanto em apenas $20 \%$ dos casos ocorre a premiação quando se aplica a taxa fixa. A explicação para essa 
associação é simples: ao premiar, o franqueador remunerado por royalty estimula o melhor desempenho dos franqueados, e já que há a remuneração em função do resultado do franqueado, melhora também o próprio resultado financeiro.

Quadro 2 - Royalty e Premiação

\begin{tabular}{|c|c|c|c|}
\hline & \multicolumn{2}{|c|}{$\begin{array}{l}\text { 10. Como o franqueador é } \\
\text { remunerado: royalties (porcentagem } \\
\text { do faturamento ou do resultado). }\end{array}$} & \multirow[t]{2}{*}{ Total } \\
\hline & Não & Sim & \\
\hline \multirow{4}{*}{$\begin{array}{ll}\text { 25. Etapas presentes na avaliação: premiação } & \text { Não } \\
\text { em função do resultado medido. } & \text { Sim }\end{array}$} & 12 & 24 & 36 \\
\hline & $80,0 \%$ & $50,0 \%$ & $57,1 \%$ \\
\hline & 3 & 24 & 27 \\
\hline & $20,0 \%$ & $50,0 \%$ & $42,9 \%$ \\
\hline \multirow[b]{2}{*}{ Total } & 15 & 48 & \\
\hline & $100,0 \%$ & $100,0 \%$ & $100,0 \%$ \\
\hline$\chi^{2}=4,20 ; p=0,04$ & & & \\
\hline
\end{tabular}

Os franqueadores remunerados apenas por taxa fixa realizam o acompanhamento do volume de produtos vendidos, relativamente, mais do que os franqueadores remunerados por royalty (Quadro 3), o que contradiz a hipótese inicial, motivo pelo qual não se realizou a prova estatística. A provável explicação para esse fato também é simples: os franqueadores remunerados por taxa fixa, e que não cobram royalty oficialmente, muitas vezes são fornecedores de produtos, e embutem o preço do royalty no valor dos produtos vendidos aos franqueados (CHERTO, 2006, p.158); logo, é normal que acompanhem as vendas de produtos com mais regularidade. O quadro 4 apresenta também a distribuição conjunta entre tipo de cobrança e acompanhamento do preenchimento dos pedidos, o que reforça essa situação: quem paga por taxa fixa têm, proporcionalmente, em sua avaliação, maior presença do acompanhamento de preenchimento dos pedidos.

Quadro 3 - Royalty por Volume de produtos

\begin{tabular}{|lc|r|r|r|}
\hline & & \multicolumn{2}{|c|}{$\begin{array}{c}\text { 10. Como o franqueador é remunerado: } \\
\text { Royalty (porcentagem do faturamento ou do } \\
\end{array}$} & \multicolumn{2}{|c|}{$\begin{array}{r}\text { resultado). } \\
\text { Total }\end{array}$} \\
\cline { 3 - 5 } & Não & 5 & Sim & \\
\hline Considerado na avaliação do & $33,3 \%$ & 27 & 32 \\
franqueador: Volume de produtos & & 10 & $61,4 \%$ & $54,2 \%$ \\
vendidos para o franqueado. & Sim & $66,7 \%$ & 17 & 27 \\
& & 15 & $38,6 \%$ & $45,8 \%$ \\
Total & & $100,0 \%$ & 44 & 59 \\
& & & $100,0 \%$ & $100,0 \%$ \\
\hline
\end{tabular}


Quadro 4 - Royalty e Pedidos preenchidos corretamente

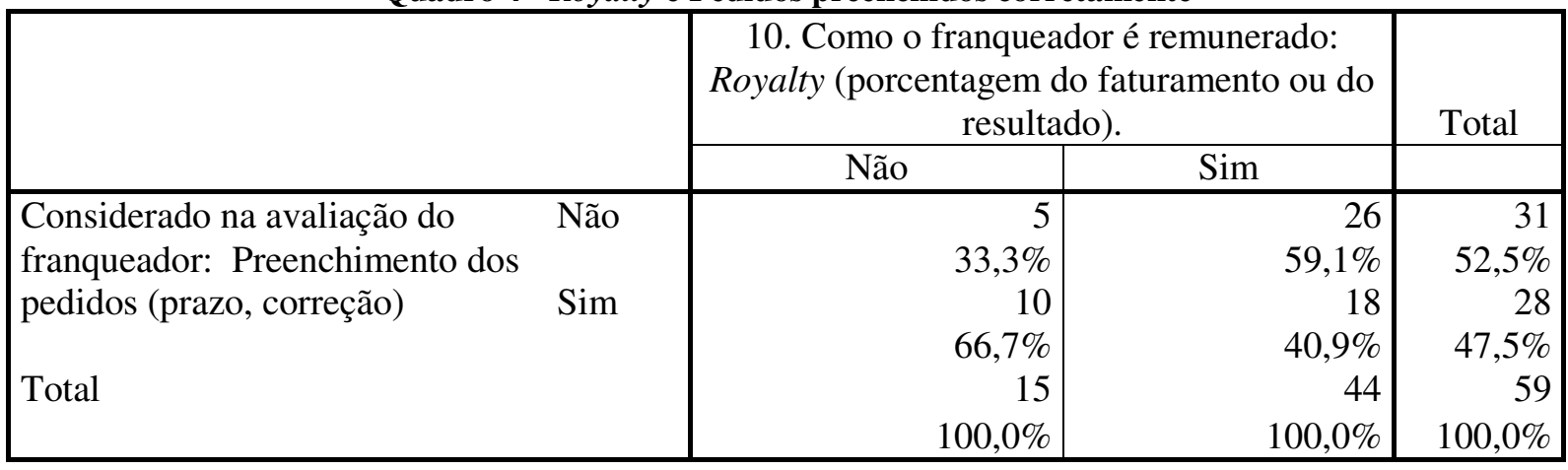

O Quadro 5 traz a variável que informa a avaliação da manutenção do maquinário e dos equipamentos. Entretanto, houve um resultado no sentido inverso ao formulado pela hipótese 1. Aqueles franqueadores remunerados por royalty avaliam, em menor proporção, a situação do equipamento e maquinário do franqueado, quando comparado aos remunerados com taxa fixa $(52,3 \%$ e $86,7 \%$, respectivamente).

Quadro 5 - Royalty e Manutenção do maquinário.

\begin{tabular}{|c|c|c|c|c|}
\hline & & $\begin{array}{r}\text { 10. Como o franquea } \\
\text { Royalty (porcentagem } \\
\text { resulta }\end{array}$ & $\begin{array}{l}\text { munerado: } \\
\text { mento ou do }\end{array}$ & Total \\
\hline & & Não & Sim & \\
\hline Considerado na avaliação do & Não & 2 & 21 & 23 \\
\hline franqueador: Manutenção do & & $13,3 \%$ & $47,7 \%$ & $39,0 \%$ \\
\hline maquinário / equipamento da loja. & Sim & 13 & 23 & 36 \\
\hline & & $86,7 \%$ & $52,3 \%$ & $61,0 \%$ \\
\hline Total & & 15 & 44 & 59 \\
\hline & & $100,0 \%$ & $100,0 \%$ & $100,0 \%$ \\
\hline
\end{tabular}

O Quadro 6 traz uma associação esperada pela hipótese 1. Os franqueadores remunerados através de royalty estão mais preocupados em verificar se se alcançaram as metas/objetivos para as lojas franqueadas. Entretanto, trata-se de um indicativo menos importante, já que se o franqueador é remunerado pelo resultado financeiro, é sua obrigação verificar ao menos se os resultados financeiros foram atingidos. 
Quadro 6 - Royalty e Verificação dos objetivos alcançados

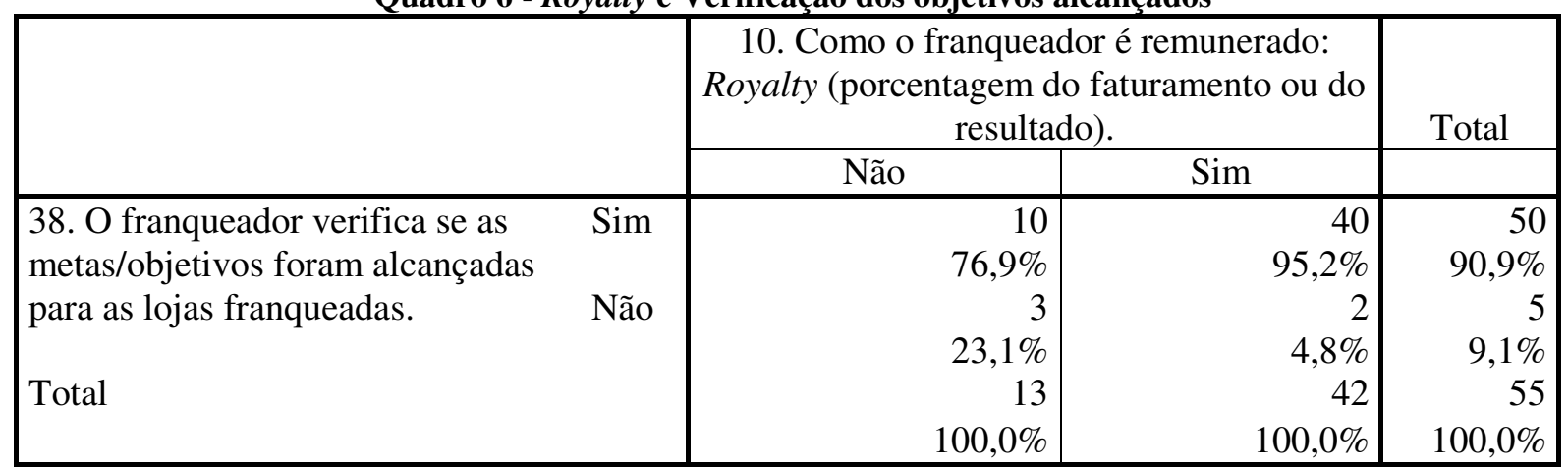

Prova de Fisher $\mathrm{p}=0,080$

Para as demais variáveis do tipo classificatória (ou nominal) binária houve 40 casos de inversão da hipótese $\mathrm{H} 1$ (1), e em 25 delas não foi possível se estabelecer dependência com a variável que identifica o tipo de pagamento da franquia, royalty ou exclusivamente taxa fixa (ver Anexo I).

Para questões que utilizavam variáveis ordinais, procedeu-se à prova de KolmogorovSmirnov, objetivando comparar as franquias que pagam por royalty e as franquias que pagam através exclusivamente de taxa fixa ao franqueador. A única diferenciação percebida foi quanto ao número de objetivos e metas que os franqueadores definem para as lojas próprias (teste unicaudal, $\mathrm{p}=0,077$ ). Nota-se no Quadro 7 que quem recebe através de royalty define maior número de objetivos.

Quadro 7 - Royalty e Quantidade de objetivos definidos

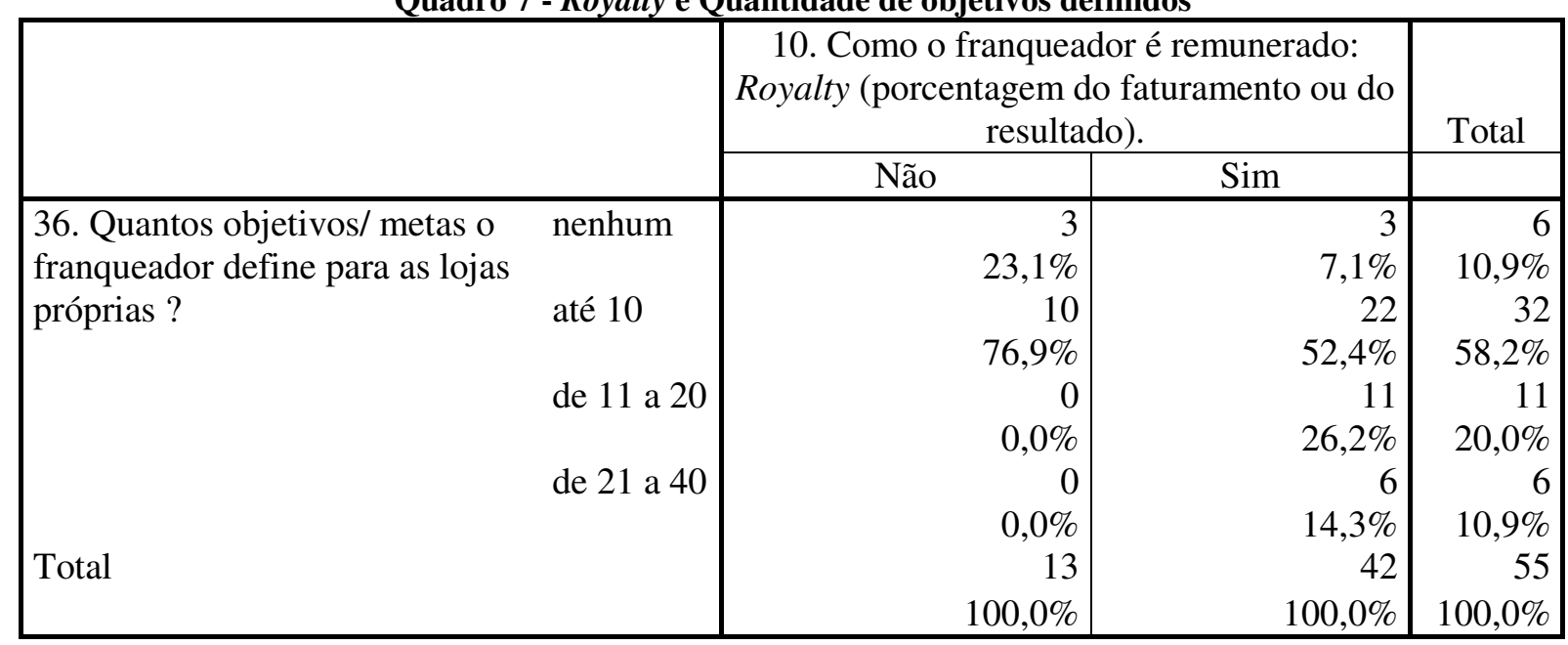


A explicação para esse fato provavelmente também se relaciona a uma maior preocupação dos franqueadores remunerados com royalty em definir objetivos financeiros com mais detalhamento, em conformidade com a primeira hipótese do trabalho. Entretanto, para as demais variáveis do tipo ordinal, não foi possível diferenciar os dois grupos (ver Anexo I).

Também se compararam os grupos de franqueadores remunerados através de royalty e de taxa fixa quanto a:

- número de lojas que operam com a marca;

- número de lojas franqueadas;

- tempo em que a marca iniciou a operação no sistema de franquias;

- investimento total para abertura de loja padrão;

- tempo de retorno do investimento médio para o franqueado padrão.

Para estas questões, procedeu-se à prova de Mann-Whitney. Para nenhuma delas foi possível diferenciar as duas amostras (ver Anexo I)

Com relação à hipótese de que os franqueadores remunerados por royalty apresentam uma avaliação mais consistente, obtiveram-se alguns poucos indícios, não sendo possível concluir pela sua correção. Aparentemente, existe por parte dos franqueadores remunerados por royalty uma preocupação maior de estabelecer uma avaliação pautada em objetivos. Isso explica as associações dessa variável (ser remunerado por royalty) com uma maior definição de objetivos, uma maior comparação dos resultados atingidos com os objetivos traçados, e uma maior premiação dos resultados. Essas associações, todavia, não são o bastante para se afirmar que a avaliação seja mais consistente, até porque há resultados no sentido inverso ao esperado. Aparentemente, ambos os grupos de franqueadores preocupam-se igualmente em avaliar os franqueados, entretanto os franqueadores remunerados por royalty concentram-se mais em objetivos definidos. As associações entre a cobrança de taxa fixa e aspectos ligados a venda de produtos ao franqueado (volume de produtos vendidos e correção dos pedidos), evidência o que afirma Cherto (2006), ou seja, que alguns franqueadores preocupam-se principalmente em vender produtos aos franqueados, embutindo no preço dos produtos fornecidos os custos da franqueadora.

Além disso, ao se realizar a prova de Kolmogorov-Smirnov, em relação aos índices criados para avaliar os módulos relativos à vendas, financeiros, manutenção/operação, imagem de 
marca, marketing, equipe, logística, parceiros, e inovação, não foi possível concluir pela maior presença no grupo com pagamento em royalties (ver Anexo I), quanto a distribuição do número de itens presentes em cada módulo.

Tabela de resultado 1 - Hipótese 1

\begin{tabular}{|c|c|}
\hline Variável & Maior proporção em relação a: \\
\hline \multirow[t]{3}{*}{ Receber por royalty } & Premiar os franqueados \\
\hline & Propor mais objetivos \\
\hline & Verificar se os objetivos foram atingidos \\
\hline \multirow{5}{*}{ Receber por taxa fixa } & 40 variáveis (etapas ou itens de avaliação) \\
\hline & Casos Notáveis: \\
\hline & Verificar o volume de produtos vendidos pelo franqueador \\
\hline & Acompanhar os pedidos feitos \\
\hline & Verificar a Manutenção do maquinário \\
\hline
\end{tabular}

\subsubsection{Processos e resultados para a Hipótese 1 (2)}

A fim de responder se os franqueadores que definem objetivos para suas lojas franqueadas e acompanham a realização desses objetivos tendem a ter uma estrutura de avaliação mais consistente, mais do que aqueles que não têm tanto foco nos objetivos, seguiram-se alguns procedimentos. Inicialmente elaborou-se um indicador, o qual considerava o número de respostas afirmativas para as seguintes questões, relacionadas às etapas presentes na avaliação das lojas franqueadas:

- definição de objetivos a serem atingidos;

- definição dos dados coletados;

- levantamento de dados;

- comparação dos resultados obtidos com esperados e relatório final;

- revisão dos objetivos;

Franqueadores que responderam afirmativamente a todas essas etapas (em número de 5), foram considerados franqueadores com um processo de avaliação estruturado para objetivos. Estes são aqueles que definem objetivos e os acompanham nas unidades franqueadas (ou 
simplesmente franqueadores com avaliação estruturada). Denominaram-se de avaliação não estruturada, ou sem foco nos objetivos as franquias que não contemplavam alguma dessas etapas em seus processos de avaliação, tendo o índice menor ou igual a 4.

$\mathrm{Na}$ amostra, são 37 (59\%) franquias de avaliação estruturada para objetivos, e 26 franquias sem foco nos objetivos.

Após a classificação da amostra nesses grupos, procurou-se saber quais outras variáveis associam-se à variável "ter uma avaliação estruturada". Para tanto, procedeu-se à prova do Qui-Quadrado (ou prova de Fisher), para variáveis nominais. Os resultados a seguir referemse às variáveis cuja hipótese de independência com "ter/ não ter avaliação estruturada" foi rejeitada ao nível de significância de $\alpha=0,05$ (testes unicaudais), confirmando-se a hipótese alternativa $\mathrm{H}_{(2)}$.

Em geral, as etapas de avaliação, estão proporcionalmente mais presentes em franquias com avaliação estruturada para objetivos, a saber:

- Definição da equipe responsável pela avaliação, presente em 91,9\% das franquias com avaliação estruturada para objetivos, ante $65,4 \%$, de presença entre as franquias não estruturadas;

- Definição das dimensões/módulos estudados. (vendas, financeiro, recursos humanos, marca, clientes), presente em $89,2 \%$ das franquias com avaliação estruturada, versus $53,8 \%$ de presença no outro grupo;

- Definição dos pesos e critérios para cada item pesquisado $(78,4 \%$ do grupo com avaliação estruturada, ante $38,5 \%$ do outro grupo);

- Construção de indicadores $(75,7 \%$, versus $34,6 \%)$;

- Integração dos resultados nos módulos ou dimensões $(62,2 \%$, ante 23,1\%);

- Sugestões de mudanças $(97,3 \%$, versus $80,8 \%)$;

- Revisão do sistema de avaliação. (67,6\%, ante 30,8\%).

Os quadros de resultados 8 até 14, a seguir, resumem as associações encontradas: 
Quadro 8 - Define e acompanha objetivos por Definiçãa da equipe

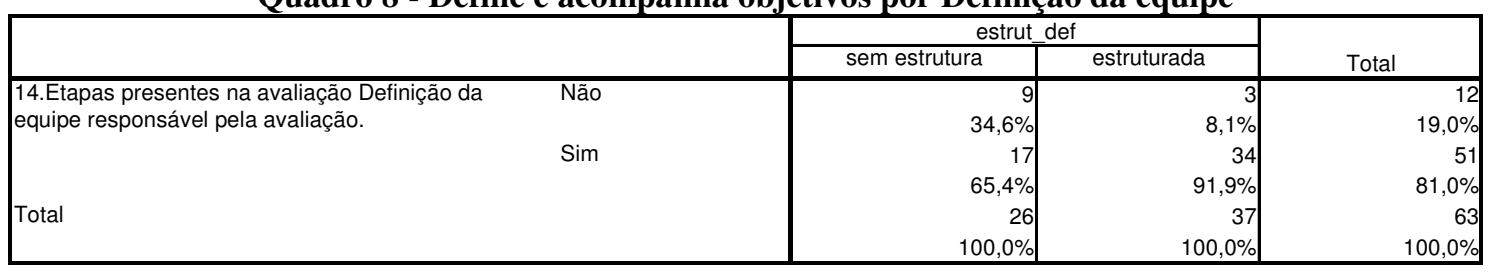

Prova de Fisher $(\mathrm{p}=0,020)$

Quadro 9 - Define e acompanha objetivos por Definição dos módulos

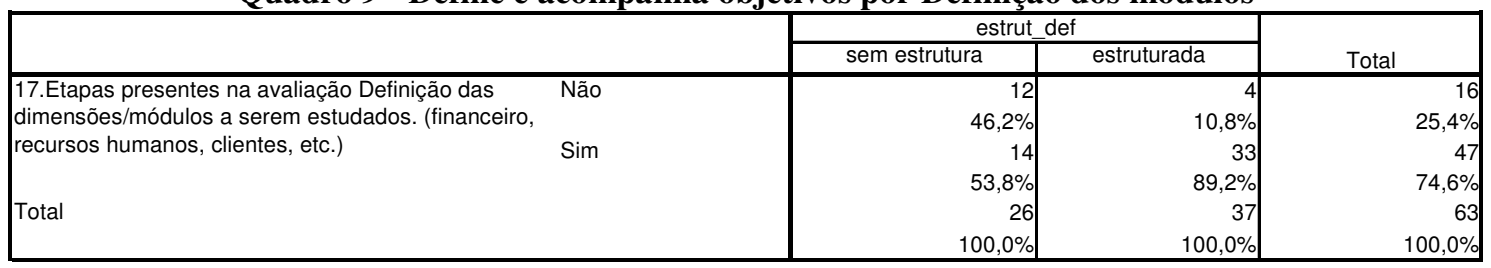

$$
\chi^{2}=10,067 ; p=0,002
$$

Quadro 10 - Define e acompanha objetivos por Definição de pesos

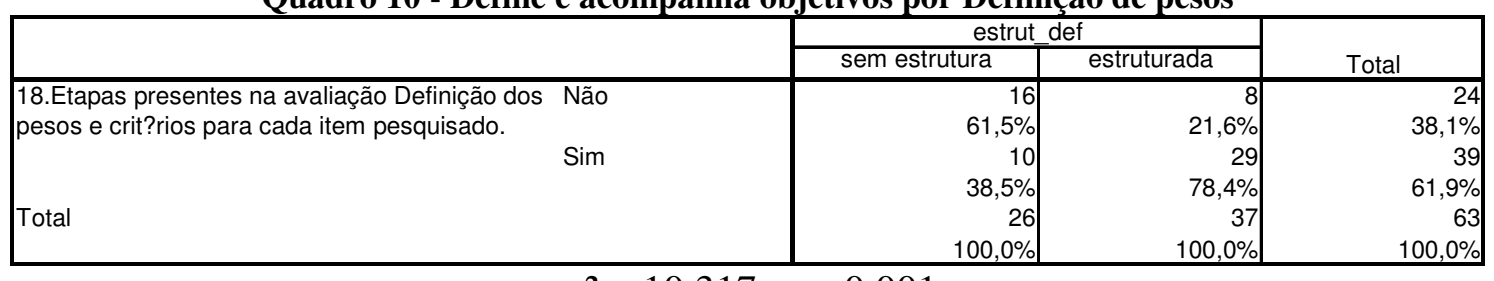

$\chi^{2}=10,317 ; p=0,001$

Quadro 11 - Define e acompanha objetivos por Construção de indicadores

\begin{tabular}{|c|c|c|c|}
\hline & \multicolumn{2}{|c|}{ estrut def } & \multirow[b]{2}{*}{ Total } \\
\hline & sem estrutura & estruturada & \\
\hline $\begin{array}{l}\text { 19.Etapas presentes na avaliação Construção de Não } \\
\text { indicadores. }\end{array}$ & $\begin{array}{r}17 \\
65,4 \%\end{array}$ & $\begin{array}{r}9 \\
24,3 \%\end{array}$ & \begin{tabular}{r|}
26 \\
$41,3 \%$
\end{tabular} \\
\hline Sim & $\begin{array}{r}9 \\
34,6 \%\end{array}$ & $\begin{array}{r}28 \\
75,7 \%\end{array}$ & $\begin{array}{r}37 \\
58,7 \%\end{array}$ \\
\hline Total & $\begin{array}{r}26 \\
100,0 \% \\
\end{array}$ & $\begin{array}{r}37 \\
100,0 \%\end{array}$ & $\begin{array}{r}63 \\
100,0 \%\end{array}$ \\
\hline
\end{tabular}

$$
\chi^{2}=10,621 ; p=0,001
$$

Quadro 12 - Define e acompanha objetivos por Integração nos módulos

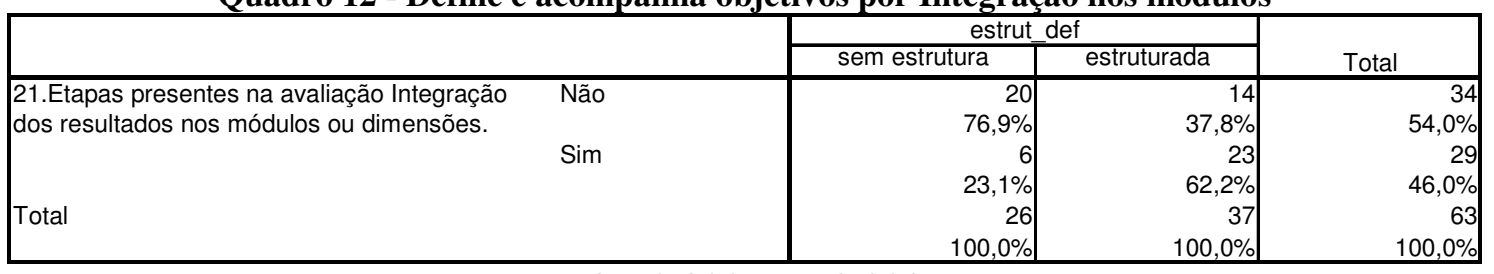

$$
\chi^{2}=9,390 ; p=0,002
$$

Quadro 13 - Define e acompanha objetivos por Sugestão de mudanças

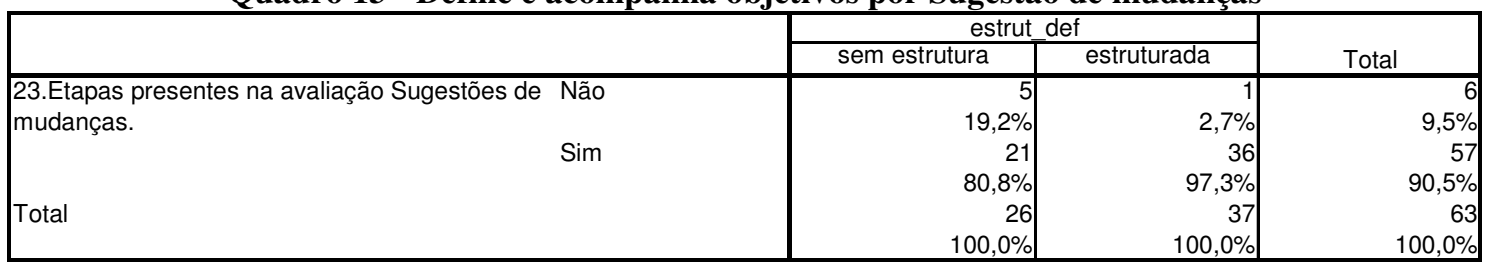

Prova de Fisher $(p=0,073)$ 
Quadro 14 - Define e acompanha objetivos por Revê a avaliação

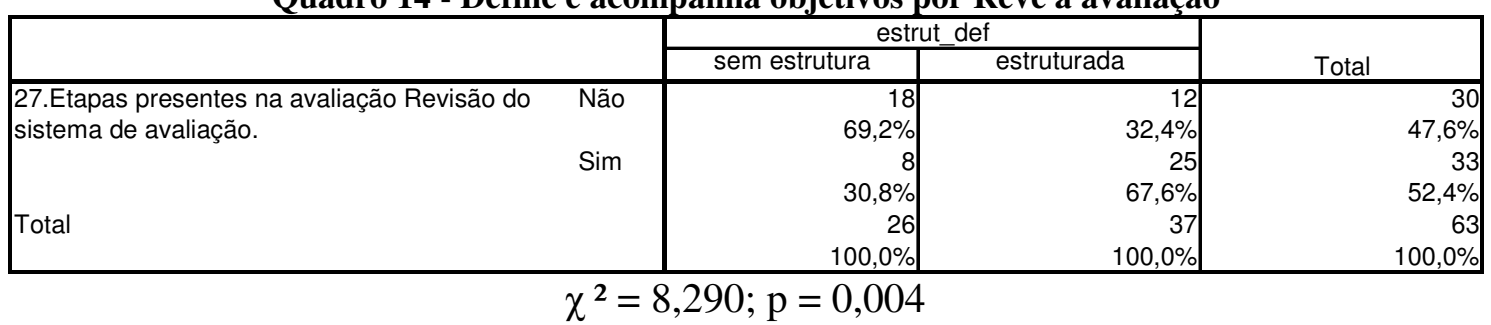

Com relação às etapas de avaliação, as únicas que se mostraram independentes da classificação proposta no estudo, para verificar a existência de uma avaliação com definição e acompanhamento de objetivos, foram as relativas à punição e a premiação dos franqueados.

A fim de se verificar se a definição de objetivos relaciona-se às dimensões sugeridas, disponíveis nas tabelas 6 e 7, criaram-se índices para cada uma dessas dimensões: vendas, financeira, imagem da marca, manutenção e operação, clientes, equipe, logística das operações, parceiros e inovação. Construíram-se os índices através da contagem das respostas afirmativas aos itens propostos para cada dimensão. Dessa forma, um franqueador que tenha respondido que no processo de avaliação acompanha apenas o "faturamento do franqueado" e as "despesas financeiras da loja", terá um índice para essa dimensão (módulo financeiro) igual a 2 .

Além desse procedimento, utilizando a classificação elaborada para sinalizar a definição e acompanhamento de objetivos no processo de avaliação, realizou-se a prova estatística para confirmar a independência com cada um dos itens do questionário (variáveis sim ou não, disponíveis na tabelas 6 e 7). Em seguida, realizou-se a prova estatística com o índice construído para cada módulo, como explicado no parágrafo anterior. No caso, a prova utilizada foi por testes unicaudais, com nível de significância de 5\%.

Observaram-se resultados significativos no teste de Qui - Quadrado em apenas dois dos itens propostos no módulo financeiro, nos quadros 15 e 16, e nenhum dos itens propostos para o módulo "aspectos relativos às vendas":

- lucro da loja (item presente em 75\% das franquias de avaliação estruturada para objetivos, ante $34,8 \%$ das franquias não estruturadas);

- outros aspectos financeiros (que não seja faturamento, giro de estoque, retorno sobre ativos,custos operacionais,despesas com impostos, despesas financeiras - 41,7\%, ante $17,4 \%)$. 
Quadro 15 - Define e acompanha objetivos por Monitora lucro

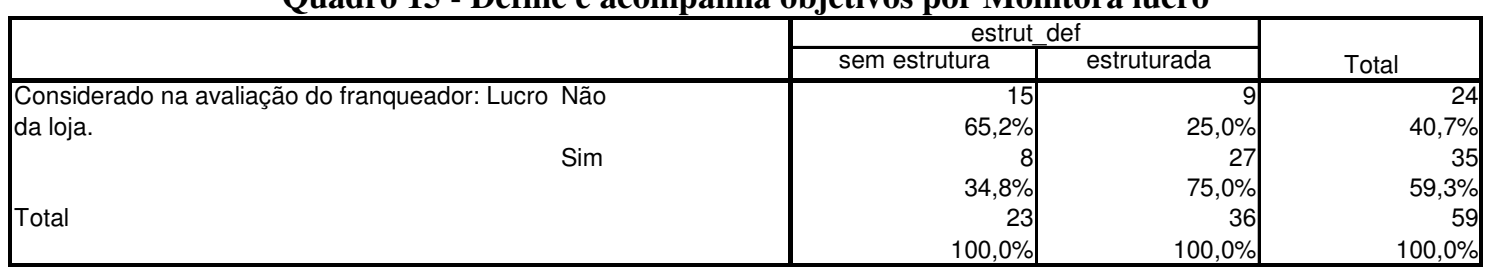

$$
\chi^{2}=9,407 ; p=0,002
$$

Quadro 16 - Define e acompanha objetivos por Outros aspectos financeiros

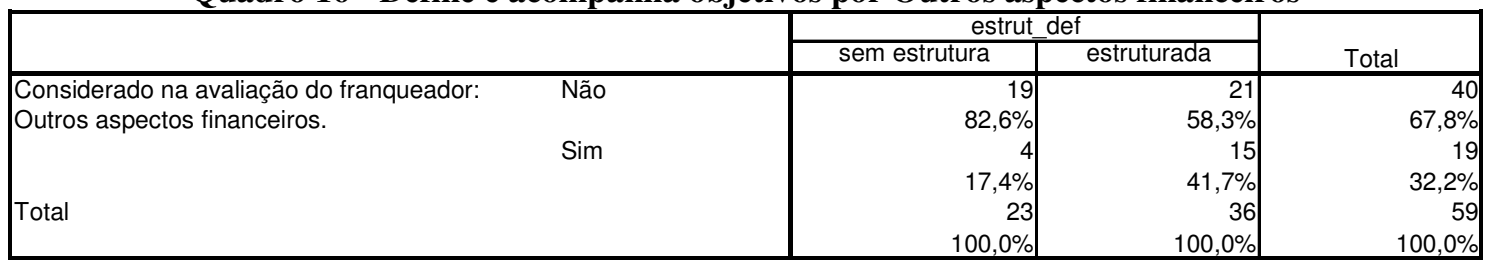

$\chi^{2}=3,788 ; p=0,052$

Além disso, ao se realizar a prova de Kolmogorov-Smirnov, em relação ao índice do módulo vendas criado, não foi possível concluir pela maior presença no grupo com avaliação estruturada para objetivos $\left(\chi^{2}=2,720 ; p>0,05\right)$, quanto à distribuição do número de itens financeiros presentes na avaliação das lojas franqueadas, conforme o quadro 17. Isso significa que o acompanhamento dos aspectos relativos às vendas, vistos como um módulo, (tabela 6) não se relacionam significativamente à construção de uma avaliação que considere objetivos claros para as lojas franqueadas, e que tenha a preocupação de se verificar se foram atingidos.

Quadro 17 - Define e acompanha objetivos por Avaliação financeira

\begin{tabular}{|cccc|cccc|}
\hline \multicolumn{3}{c|}{ estrut_def $=$ sem estrutura } & \multicolumn{4}{c|}{ estrut_def = estruturada } \\
$\begin{array}{c}\text { avalia } \\
\text { aspectos } \\
\text { vendas }\end{array}$ & Freqüência & Percentual & $\begin{array}{c}\text { Percentual } \\
\text { Acumulado }\end{array}$ & $\begin{array}{c}\text { avalia } \\
\text { aspectos } \\
\text { vendas }\end{array}$ & Frequiência & Percentual & $\begin{array}{c}\text { Acumulado } \\
0\end{array}$ \\
1 & 9 & 34,6 & 34,6 & 0 & 5 & 13,5 & 13,5 \\
2 & 5 & 19,2 & 53,8 & 1 & 11 & 29,7 & 43,2 \\
3 & 2 & 7,7 & 61,5 & 2 & 7 & 18,9 & 62,2 \\
4 & 3 & 26,9 & 88,5 & 3 & 9 & 24,3 & 86,5 \\
Total & 26 & 11,5 & 100 & 4 & 5 & 13,5 & 100 \\
\hline
\end{tabular}

A maior diferença entre os percentuais acumulados foi de 21,1 pontos percentuais, diferença não significante estatisticamente $(\alpha=0,10)$. 
Tampouco foi possível encontrar diferenças significativas em relação ao módulo financeiro $\left(\chi^{2}=4,092 ; p>0,10\right)$, em relação ao módulo logística $\left(\chi^{2}=3,770 ; p>0,05\right)$ e aos aspectos relacionados a parceiros $\left(\chi^{2}=3,023 ; \mathrm{p}>0,05\right)$.

Por outro lado, as provas estatísticas apresentam 5 associações em relação aos aspectos operacionais, em um total de 7 itens. Em relação aos aspectos operacionais, listam-se, a seguir, as freqüências percentuais nas quais se obteve significância estatística, e os resultados disponíveis nos quadros de 18 até 22 (porcentagem de presença em redes com definição de objetivos, versus porcentagem de presença em redes com avaliação sem estrutura para objetivos.):

- manutenção do maquinário/equipamento da loja: 77,8\% versus 34,8\%;

- condições do espaço físico (manutenção): 88,9\% ante 65,2\%;

- atualização tecnológica (máquinas, computadores, softwares, etc...): 69,4\% contra 43,5\%;

- consumo de energia/água da loja: $38,9 \%$ versus $13 \%$;

- condições de higiene na loja: $89,9 \%$ contra $69,6 \%$.

Quadro 18 - Define e acompanha objetivos por Manutenção

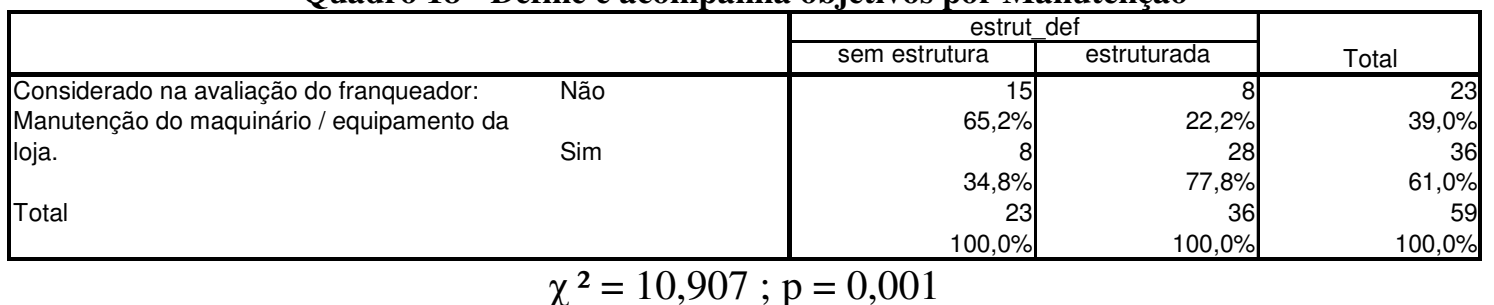

Quadro 19 - Define e acompanha objetivos por Espaço físico

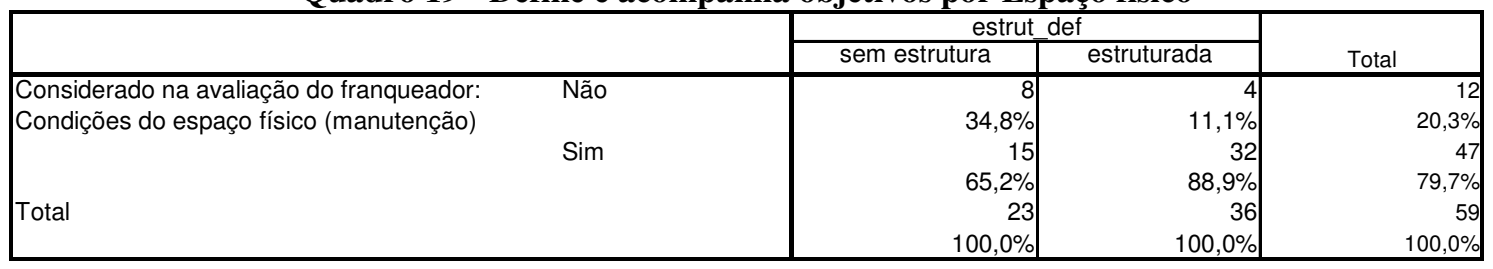

Prova de Fisher ; $\mathrm{p}=0,045$

Quadro 20 - Define e acompanha objetivos por Atualização

\begin{tabular}{|c|c|c|c|c|}
\hline & \multicolumn{2}{|c|}{ estrut_def } & \multirow[b]{2}{*}{ Total } \\
\hline & & sem estrutura & estruturada & \\
\hline $\begin{array}{l}\text { Considerado na avaliação do franqueador: } \\
\text { Atualização tecnológica (máquinas, } \\
\text { computadores, softwares, etc...) } \\
\text { Total }\end{array}$ & $\begin{array}{l}\text { Não } \\
\text { Sim }\end{array}$ & \begin{tabular}{r|}
13 \\
$56,5 \%$ \\
10 \\
$43,5 \%$ \\
23 \\
$100,0 \%$
\end{tabular} & \begin{tabular}{r|}
11 \\
$30,6 \%$ \\
25 \\
$69,4 \%$ \\
36 \\
$100,0 \%$
\end{tabular} & \begin{tabular}{r|}
24 \\
$40,7 \%$ \\
35 \\
$59,3 \%$ \\
59 \\
$100,0 \%$
\end{tabular} \\
\hline
\end{tabular}

$\chi^{2}=3,921 ; p=0,048$ 
Quadro 21 - Define e acompanha objetivos por Consumo energia

\begin{tabular}{|c|c|c|c|c|}
\hline & \multicolumn{2}{|c|}{ estrut_def } & \multirow[b]{2}{*}{ Total } \\
\hline & & sem estrutura & estruturada & \\
\hline \multirow{4}{*}{$\begin{array}{l}\text { Considerado na avaliação do franqueador } \\
\text { Consumo de energia / água da loja }\end{array}$} & Não & 20 & 22 & 42 \\
\hline & & $87,0 \%$ & $61,1 \%$ & $71,2 \%$ \\
\hline & Sim & & & \\
\hline & & $13,0 \%$ & $38,9 \%$ & $28,8 \%$ \\
\hline \multirow{2}{*}{\multicolumn{2}{|c|}{ Total }} & & & \\
\hline & & $100,0 \%$ & $100,0 \%$ & $100,0 \%$ \\
\hline
\end{tabular}

$\chi^{2}=4,570 ; p=0,033$

Quadro 22 - Define e acompanha objetivos por Higiene na loja

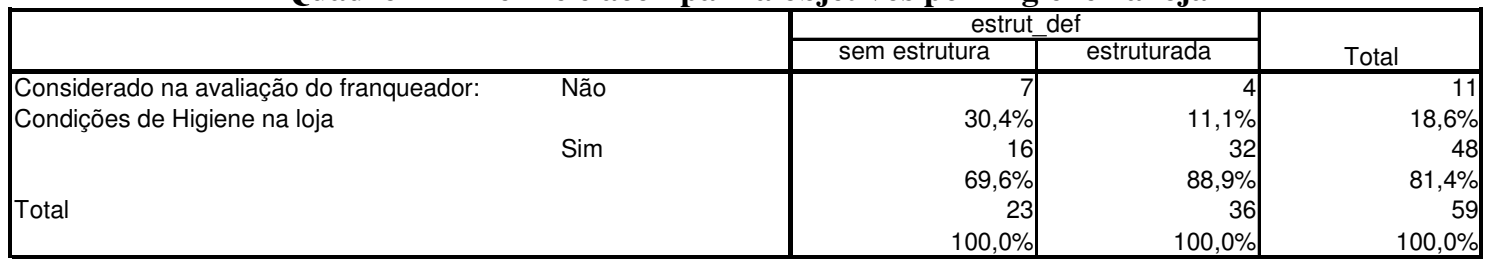

Prova de Fisher; $\mathrm{p}=0,089$

E também, ao se realizar a prova de Kolmogorov-Smirnov, em relação ao índice de avaliação operacional, conclui-se que a avaliação quanto aos itens de operação/manutenção está, proporcionalmente mais presente no grupo de franquias que utilizam definição de objetivos e acompanhamento de sua consecução $\left(\chi^{2}=10,090\right)$.

Quadro 23 - Define e acompanha objetivos por Índice de operação.

\begin{tabular}{|c|c|c|c|c|c|c|c|}
\hline \multicolumn{4}{|c|}{ Estrut def $=$ sem estrutura } & \multicolumn{4}{|c|}{ Estrut def = estruturada } \\
\hline avalia & & & & avalia & & & \\
\hline aspecto & & & & aspecto & & & \\
\hline operação & & & Percentual & operação & & & Percentual \\
\hline manutenção & Freq. & Percentual & Acumulado & manutenção & Freq. & Percentual & Acumulado \\
\hline 0 & 5 & 19,2 & 19,2 & 0 & 1 & 2,7 & 2,7 \\
\hline 1 & 3 & 11,5 & 30,8 & 1 & 1 & 2,7 & 5,4 \\
\hline 2 & 3 & 11,5 & 42,3 & 2 & 1 & 2,7 & 8,1 \\
\hline 3 & 4 & 15,4 & 57,7 & 3 & 4 & 10,8 & 18,9 \\
\hline 4 & 4 & 15,4 & 73,1 & 4 & 5 & 13,5 & 32,4 \\
\hline 5 & 3 & 11,5 & 84,6 & 5 & 9 & 24,3 & 56,8 \\
\hline 6 & 1 & 3,8 & 88,5 & 6 & 7 & 18,9 & 75,7 \\
\hline 7 & 3 & 11,5 & 100 & 7 & 9 & 24,3 & 100 \\
\hline Total & 26 & 100 & & Total & 37 & 100 & \\
\hline
\end{tabular}

O quadro 23 evidência que em franqueadores que definem e acompanham os objetivos (avaliação estruturada), há maiores percentuais em maiores índices. Em outras palavras, os maiores índices de avaliação (escores de 5, 6 e 7) correspondem a 25 franquias, ou 67,5\% $(24,3+18,9+24,3)$ dos respondentes nas franquias que definem objetivos, e os mesmos escores correspondem a apenas $26,8 \%(11,5+3,8+11,5)$ das franquias que não o fazem. 
Em relação aos aspectos da dimensão/módulo imagem da marca, encontrou-se, relativamente, maior presença no grupo de franquias que definem objetivos e os acompanham, frente ao outro grupo, em dois dos quatro aspectos propostos para avaliar o módulo. O primeiro já se apresentara no quadro 22, e se relaciona às condições de higiene da loja; o quadro 24 discute o segundo aspecto. Ocorre maior frequiência de avaliação também no item do módulo: Condições da fachada/vitrine: $94,4 \%$ contra $73,9 \%$

Quadro 24 - Define e acompanha objetivos por Fachada

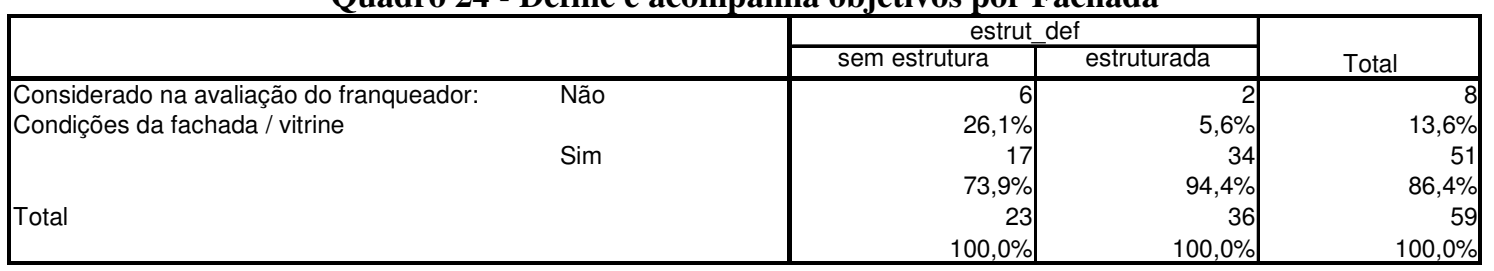

Prova de Fisher; $p=0,047$

Quanto ao índice construído para verificar o módulo referente à imagem de marca, na prova de Kolmogorov-smirnov foi possível encontrar proporcionalmente maior presença dos itens nos franqueadores que se preocupam em definir objetivos e verificar se foram atingidos, conforme o quadro $25\left(\chi^{2}=5,064\right)$.

Quadro 25 - Define e acompanha objetivos por Índice imagem da marca.

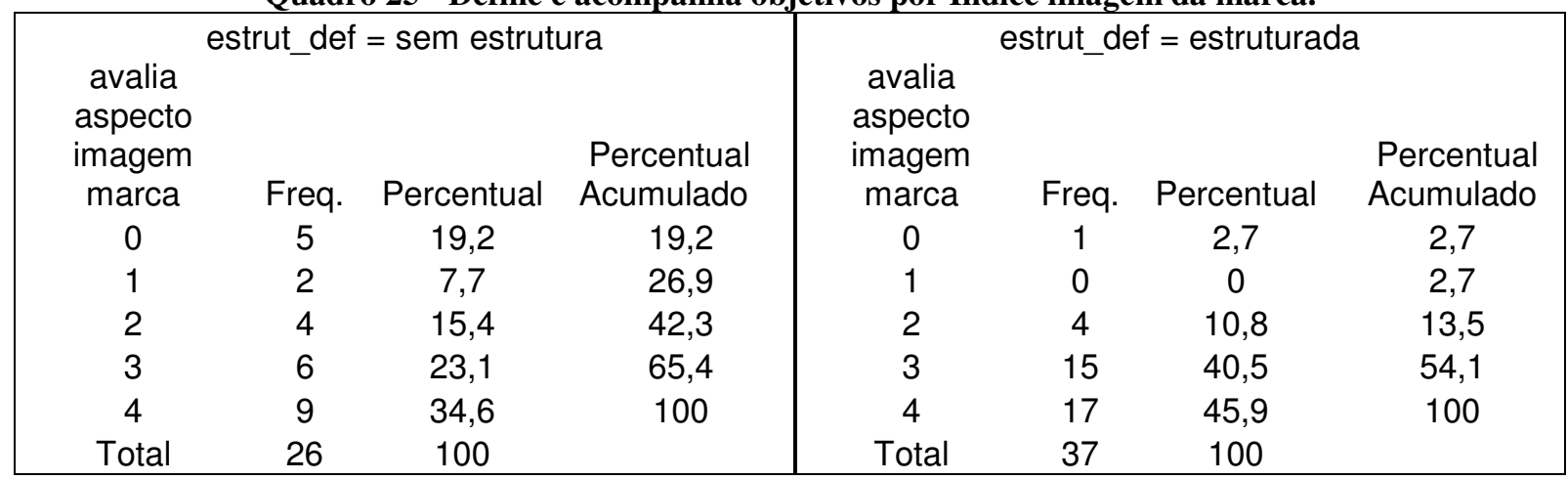

Em relação à imagem da marca, nas franquias que definem e acompanham os objetivos para os franqueados (estruturadas), os escores mais altos (3 e 4) são responsáveis por 86\% dos respondentes, enquanto esse índice refere-se à 57,8\% das outras franquias (sem estrutura).

Em relação aos aspectos da dimensão clientes, há, relativamente, maior presença no grupo de franquias com definição de objetivos frente ao outro grupo, em 4 dos 7 itens propostos, conforme os quadros 26 até 29. (porcentagem de presença em redes com avaliação estruturada, versus porcentagem de presença em redes com avaliação sem estrutura.): 
- aumento/diminuição da concorrência na região da loja: $69,4 \%$ versus $34,8 \%$;

- fidelização dos clientes da loja (retorno do mesmo cliente): 83,3\% versus 60,9\%;

- perfil dos clientes da loja (renda, faixa etária, gênero): $61,1 \%$ versus $34,8 \%$;

- atendimento ao cliente na loja (tempo, pós-venda): 83,3\% versus $60,9 \%$.

Quadro 26 - Define e acompanha objetivos por Mudanças na concorrência

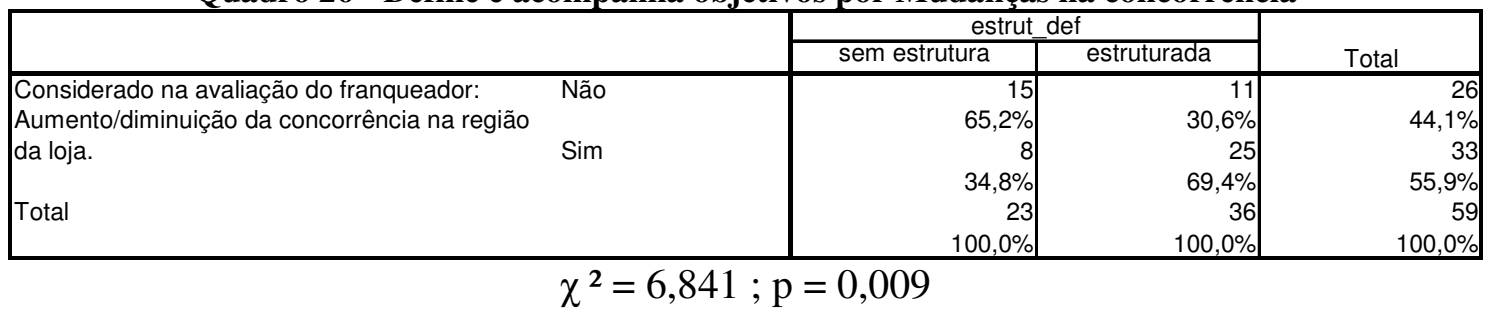

Quadro 27 - Define e acompanha objetivos por Fidelização.

\begin{tabular}{|c|c|c|c|c|}
\hline & \multicolumn{2}{|c|}{ estrut def } & \multirow[b]{2}{*}{ Total } \\
\hline & & sem estrutura & estruturada & \\
\hline $\begin{array}{l}\text { Considerado na avaliação do franqueador: } \\
\text { Fidelização dos clientes da loja (retorno do } \\
\text { mesmo cliente) } \\
\text { Total }\end{array}$ & $\begin{array}{l}\text { Não } \\
\text { Sim }\end{array}$ & $\begin{array}{r}9 \\
39,1 \% \\
14 \\
60,9 \% \\
23 \\
100,0 \%\end{array}$ & $\begin{array}{r}6 \\
16,7 \% \\
30 \\
83,3 \% \\
36 \\
100,0 \%\end{array}$ & $\begin{array}{r}15 \\
25,4 \% \\
44 \\
74,6 \% \\
59 \\
100,0 \%\end{array}$ \\
\hline
\end{tabular}

$$
\chi^{2}=3,735 ; p=0,053
$$

Quadro 28 - Define e acompanha objetivos por Perfil do cliente

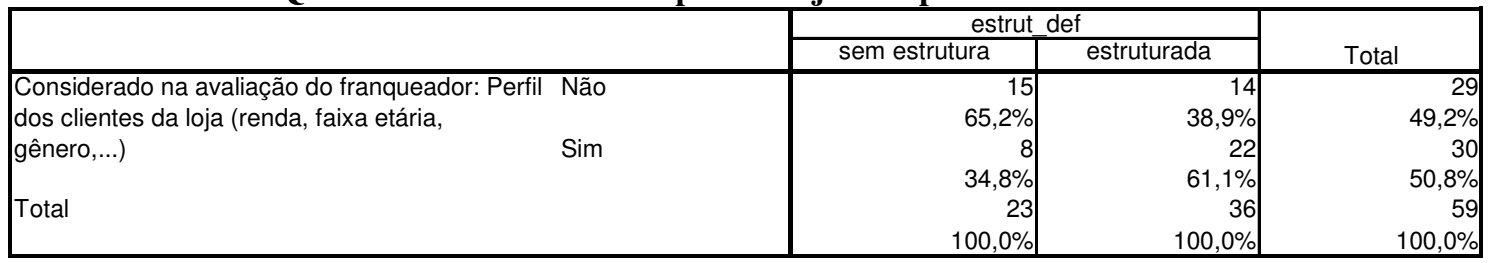

$$
\chi^{2}=3,892 ; p=0,049
$$

\begin{tabular}{|c|c|c|c|c|}
\hline & \multicolumn{2}{|c|}{ estrut_def } & \multirow[b]{2}{*}{ Total } \\
\hline & & sem estrutura & estruturada & \\
\hline \multirow{6}{*}{$\begin{array}{l}\text { Considerado na avaliação do franqueador: } \\
\text { Atendimento ao cliente na loja (tempo, pós- } \\
\text { venda,...) }\end{array}$} & Não & 9 & 6 & 15 \\
\hline & & $39,1 \%$ & $16,7 \%$ & $25,4 \%$ \\
\hline & Sim & & & \\
\hline & & $60,9 \%$ & $83,3 \%$ & $74,6 \%$ \\
\hline & & 23 & 36 & \\
\hline & & $100,0 \%$ & $100,0 \%$ & $100,0 \%$ \\
\hline
\end{tabular}

Quadro 29 - Define e acompanha objetivos por Atendimento

$$
\chi^{2}=3,735 ; p=0,053
$$

Em resumo, ao se realizar a prova de Kolmogorov-Smirnov, em relação ao índice de avaliação operacional, também se conclui que avaliação quanto à dimensão clientes é proporcionalmente mais presente em franquias que definem objetivos para os franqueados e os acompanham $\left(\chi^{2}=7,101 ; \mathrm{p} \leq 0,05\right)$, conforme quadro 30 . Nota-se que em franquias que definem objetivos e acompanham sua execução há maiores percentuais em maiores índices. 
Quadro 30 - Define e acompanha objetivos por Índice da dimensão cliente

\begin{tabular}{|c|c|c|c|c|c|c|c|}
\hline \multirow{2}{*}{\multicolumn{4}{|c|}{$\begin{array}{l}\text { estrut_def }=\text { sem estrutura } \\
\text { avalia }\end{array}$}} & \multirow{2}{*}{\multicolumn{4}{|c|}{ estrut_def = estruturada }} \\
\hline & & & & & & & \\
\hline $\begin{array}{l}\text { aspecto } \\
\text { clientes }\end{array}$ & Freq. & Percentual & $\begin{array}{l}\text { Percentual } \\
\text { Acumulado }\end{array}$ & $\begin{array}{l}\text { aspecto } \\
\text { clientes }\end{array}$ & Freq. & Percentual & $\begin{array}{l}\text { Percentual } \\
\text { Acumulado }\end{array}$ \\
\hline 0 & 6 & 23,1 & 23,1 & 0 & 1 & 2,7 & 2,7 \\
\hline 1 & 4 & 15,4 & 38,5 & 1 & 4 & 10,8 & 13,5 \\
\hline 2 & 3 & 11,5 & 50 & 2 & 2 & 5,4 & 18,9 \\
\hline 3 & 5 & 19,2 & 69,2 & 3 & 6 & 16,2 & 35,1 \\
\hline 4 & 3 & 11,5 & 80,8 & 4 & 6 & 16,2 & 51,4 \\
\hline 5 & 2 & 7,7 & 88,5 & 5 & 8 & 21,6 & 73 \\
\hline 6 & 3 & 11,5 & 100 & 6 & 10 & 27 & 100 \\
\hline Total & 26 & 100 & & Total & 37 & 100 & \\
\hline
\end{tabular}

Em relação à gestão de pessoal, os quadros de 31 até 35 resumem os resultados estatísticos, ocorrendo associação nos 5 itens abaixo, de um total de 7 (porcentagem de presença em redes com avaliação estruturada versus porcentagem de presença em redes com avaliação sem estrutura):

- eficiência dos funcionários da loja: $100 \%$ contra 78,3\%;

- treinamento do franqueado/gestor/administrativo: 97,2\% ante 73,9\%;

- treinamento do pessoal operacional: $100 \%$ versus $78,3 \%$;

- qualidade do atendimento na loja: 100\% ante 73,9\%;

- identificação da equipe da loja com os atributos da marca: 80,6\% contra 52,2\%.

Quadro 31 - Define e acompanha objetivos por Eficiência dos funcionários

\begin{tabular}{|c|c|c|c|c|}
\hline & \multicolumn{2}{|c|}{ estrut def } & \multirow[b]{2}{*}{ Total } \\
\hline & & sem estrutura & estruturada & \\
\hline \multirow[t]{2}{*}{$\begin{array}{l}\text { Considerado na avaliação do franqueador: } \\
\text { Eficiência dos funcionários da loja }\end{array}$} & & $\begin{array}{r}5 \\
21,7 \%\end{array}$ & \begin{tabular}{r|}
0 \\
$0,0 \%$
\end{tabular} & $8,5 \%$ \\
\hline & Sim & $\begin{array}{r}18 \\
78.3 \%\end{array}$ & $\begin{array}{r}36 \\
100.0 \%\end{array}$ & $\begin{array}{r}54 \\
915 \%\end{array}$ \\
\hline \multicolumn{2}{|l|}{ Total } & & & 59 \\
\hline & & $100,0 \%$ & $100,0 \%$ & $100,0 \%$ \\
\hline
\end{tabular}

Prova de Fisher; $p=0,007$

Quadro 32 - Define e acompanha objetivos por Treinamento do franqueado

\begin{tabular}{|c|c|c|c|c|}
\hline & \multicolumn{2}{|c|}{ estrut_def } & \multirow[b]{2}{*}{ Total } \\
\hline & & sem estrutura & estruturada & \\
\hline $\begin{array}{l}\text { Considerado na avaliação do franqueador: } \\
\text { Treinamento do franqueado / gestor } \\
\text { /administrativo } \\
\text { Total }\end{array}$ & $\begin{array}{l}\text { Não } \\
\text { Sim }\end{array}$ & \begin{tabular}{r|}
6 \\
$26,1 \%$ \\
17 \\
$73,9 \%$ \\
23 \\
$100,0 \%$
\end{tabular} & \begin{tabular}{r|}
1 \\
$2,8 \%$ \\
35 \\
$97,2 \%$ \\
36 \\
$100,0 \%$
\end{tabular} & $\begin{array}{r}7 \\
11,9 \% \\
52 \\
88,1 \% \\
59 \\
100,0 \%\end{array}$ \\
\hline
\end{tabular}

Prova de Fisher; $p=0,011$ 
Quadro 33 - Define e acompanha objetivos por Treinamento equipe

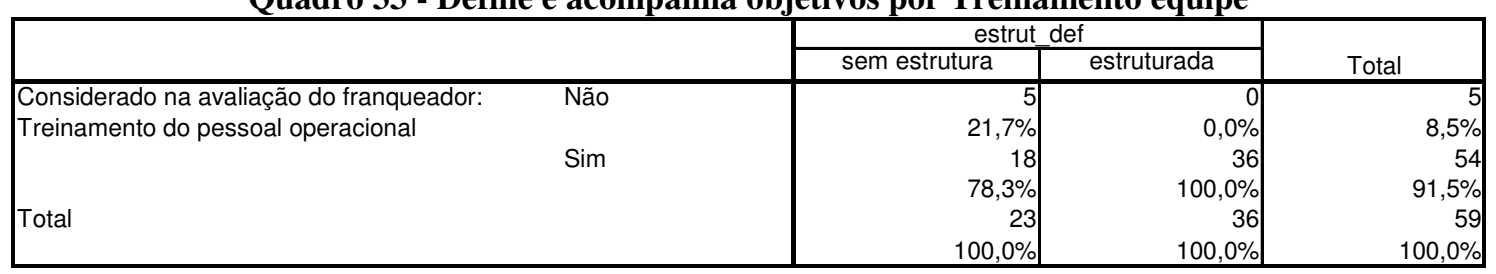

Prova de Fisher; $p=0,007$

Quadro 34 - Define e acompanha objetivos por Atendimento da equipe

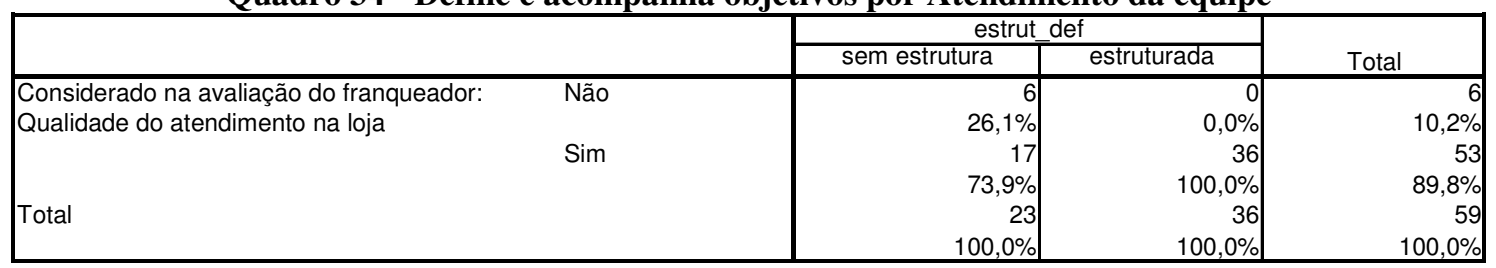

Prova de Fisher; $p=0,002$

Quadro 35 - Define e acompanha objetivos por Identificação com a marca

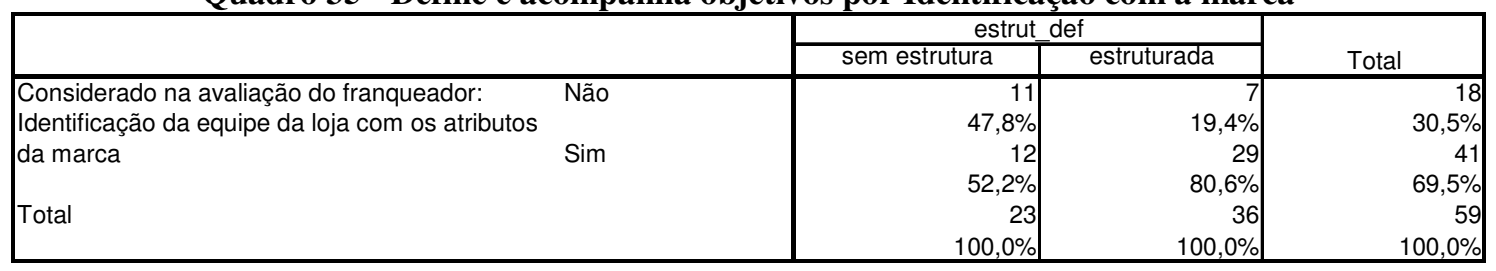

$\chi^{2}=5,332 ; p=0,021$

Também, ao se realizar a prova de Kolmogorov-Smirnov, em relação ao índice de avaliação da dimensão equipe, conclui-se que a avaliação é, proporcionalmente mais presente em franquias que definem objetivos e acompanham sua execução $\left(\chi^{2}=8,841 ; p \leq 0,05\right)$, conforme o quadro 36. Nota-se que em franquias estruturadas há maiores percentuais em maiores índices.

Quadro 36 - Define e acompanha objetivos por Índice relativo a equipe

\begin{tabular}{|c|c|c|c|c|c|c|c|}
\hline \multicolumn{4}{|c|}{ estrut_def $=$ sem estrutura } & \multicolumn{4}{|c|}{ estrut_def $=$ estruturada } \\
\hline $\begin{array}{c}\text { avalia aspecto } \\
\text { equipe }\end{array}$ & Freq. & Percentual & $\begin{array}{r}\text { Percentual } \\
\text { Acumulado }\end{array}$ & $\begin{array}{c}\text { avalia aspecto } \\
\text { equipe }\end{array}$ & Freq. & Percentual & $\begin{array}{r}\text { Percentual } \\
\text { Acumulado }\end{array}$ \\
\hline 0 & 5 & 19,2 & 19,2 & 0 & 1 & 2,7 & 2,7 \\
\hline 2 & 2 & 7,7 & 26,9 & 2 & 0 & 0 & 2,7 \\
\hline 3 & 2 & 7,7 & 34,6 & 3 & 0 & 0 & 2,7 \\
\hline 4 & 4 & 15,4 & 50 & 4 & 2 & 5,4 & 8,1 \\
\hline 5 & 2 & 7,7 & 57,7 & 5 & 6 & 16,2 & 24,3 \\
\hline 6 & 1 & 3,8 & 61,5 & 6 & 6 & 16,2 & 40,5 \\
\hline 7 & 10 & 38,5 & 100 & 7 & 22 & 59,5 & 100 \\
\hline Total & 26 & 100 & & Total & 37 & 100 & \\
\hline
\end{tabular}


Quanto aos aspectos relativos à dimensão logística, não foi possível apontar qualquer associação com os itens propostos (isoladamente) e em ter/ não ter avaliação estruturada.

Porém, no cômputo geral, através da Prova de Kolmogorov-Smirnov, em relação ao índice de logística, conclui-se que a realização da avaliação é, proporcionalmente, mais presente em franquias do primeiro grupo $\left(\chi^{2}=5,589 ; \mathrm{p} \leq 0,10\right)$. No quadro 37 , apresenta-se essa distribuição da presença do número de itens de logística avaliados em cada grupo.

Quadro 37 - Define e acompanha objetivos por Dimensão relativa a logística

\begin{tabular}{|cccc|ccc|}
\hline \multirow{5}{*}{ índice } & estrut_def = sem estrutura & & \multicolumn{3}{|c|}{ estrut_def $=$ estruturada } \\
0 & Frequency & $\%$ & \% acumulado & Frequency & $\%$ & $\%$ acumulado \\
1 & 6 & 23,1 & 23,1 & 2 & 5,4 & 5,4 \\
2 & 4 & 15,4 & 38,5 & 7 & 18,9 & 24,3 \\
3 & 7 & 26,9 & 65,4 & 4 & 10,8 & 35,1 \\
4 & 2 & 7,7 & 73,1 & 7 & 18,9 & 54,1 \\
5 & 0 & 0 & 73,1 & 3 & 8,1 & 62,2 \\
6 & 0 & 0 & 73,1 & 4 & 10,8 & 73 \\
7 & 3 & 11,5 & 84,6 & 4 & 10,8 & 83,8 \\
Total & 4 & 15,4 & 100 & 6 & 16,2 & 100 \\
\hline
\end{tabular}

Nota-se que em franquias não-estruturadas há maiores percentuais em índices mais baixos. Por exemplo, como destacado, considerando até o índice 2 (o franqueador avalia até dois itens relativos a logística), há uma porcentagem acumulada de $65,4 \%$ dos franqueadores que não definem objetivos, e apenas $35,1 \%$ dos franqueadores que definem e os acompanham.

Quanto ao relacionamento com parceiros e com a rede, há apenas uma associação entre os seis itens propostos. (porcentagem de presença em redes com avaliação estruturada versus porcentagem de presença em redes com avaliação sem estrutura):

- participação da loja em ações promocionais da rede: 88,9\% versus 52,2\%.

Ao se realizar a prova de Kolmogorov-Smirnov, em relação ao índice que mede o relacionamento do franqueado com a rede e os parceiros, não foi possível concluí-la pela diferenciação entre as duas amostras $\left(\chi^{2}=2,535 ; \mathrm{p}>0,10\right)$, conforme o quadro 39 .

Quadro 38 - Define e acompanha objetivos por Participação em ações da rede

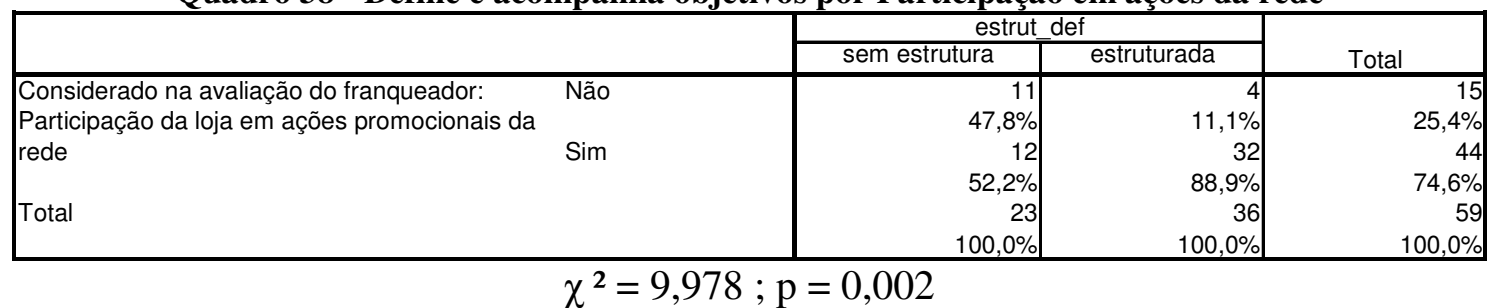


Quadro 39 - Define e acompanha objetivos por Índice relativo a parcerias.

\begin{tabular}{|cccc|ccc|}
\hline & \multicolumn{4}{c|}{ estrut_def = sem estrutura } & & \multicolumn{4}{l|}{ estrut_def $=$ estruturada } \\
índice & Frequency & $\%$ & $\%$ acumulado & Frequency & $\%$ & $\%$ acumulado \\
0 & 6 & 23,1 & 23,1 & 1 & 2,7 & 2,7 \\
1 & 4 & 15,4 & 38,5 & 6 & 16,2 & 18,9 \\
2 & 4 & 15,4 & 53,8 & 6 & 16,2 & 35,1 \\
3 & 4 & 15,4 & 69,2 & 7 & 18,9 & 54,1 \\
4 & 5 & 19,2 & 88,5 & 11 & 29,7 & 83,8 \\
5 & 3 & 11,5 & 100 & 6 & 16,2 & 100 \\
Total & 26 & 100 & & 37 & 100 & \\
\hline
\end{tabular}

A maior diferença entre os percentuais acumulados foram 20,4 pontos percentuais, diferença não significante estatisticamente $(\alpha=0,05)$, ou seja, a presença dos itens relativos ao relacionamento com parceiros e com a rede não é maior nas franquias preocupadas em definir objetivos, em comparação aquelas que não os definem.

Em relação aos itens relativos a inovação, todos os 4 itens propostos apresentaram associação com a variável criada para medir se o franqueador define objetivos, e verificar se foram atingidos. Estatisticamente falando, essas variáveis são, relativamente, mais presentes em franquias que definem objetivos e os acompanham, ante as outras franquias, conforme os quadros 39 a 41 . O item atualização tecnológica já fora comentado em aspectos operacionais, conforme quadro 20:

- atualização tecnológica (máquinas, computadores, softwares): 69,4\% contra 43,5\%;

- avaliação das inovações propostas à loja pelo franqueador: 83,3\% ante 47,8\%;

- avaliação das inovações criadas pelo franqueado: $80,6 \%$ versus $43,5 \%$;

- avaliação das sugestões de mudanças propostas pelo franqueado: 83,3\% ante 60,9\%.

Quadro 40 - Define e acompanha objetivos por Inovações do franqueador

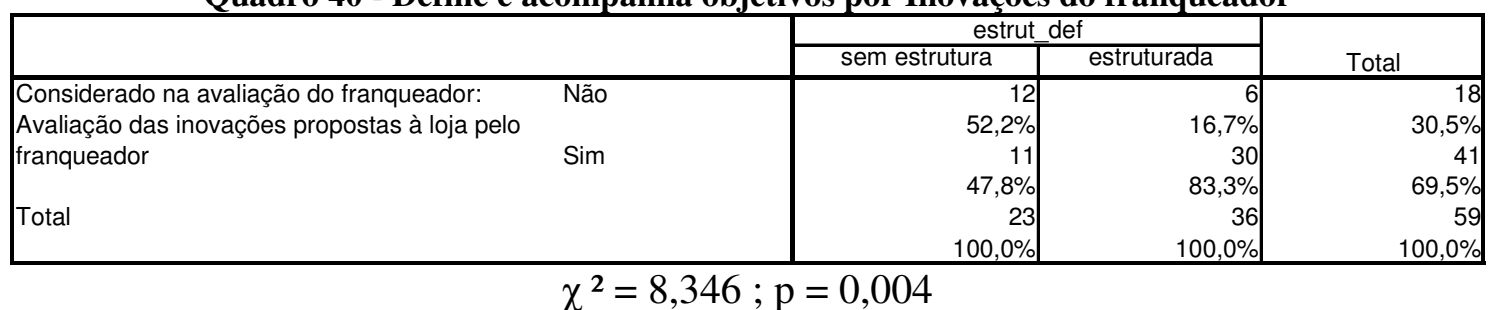

Quadro 41 - Define e acompanha objetivos por Inovações do franqueado

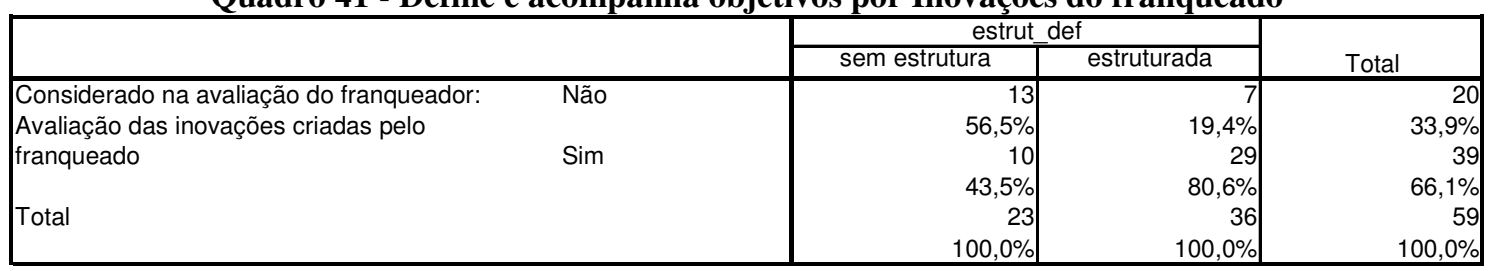

$\chi^{2}=8,610 ; p=0,003$ 
Quadro 42 - Define e acompanha objetivos por Sugestões de mudanças

\begin{tabular}{|c|c|c|c|c|}
\hline & \multicolumn{2}{|c|}{ estrut_def } & \multirow[b]{2}{*}{ Total } \\
\hline & & sem estrutura & estruturada & \\
\hline $\begin{array}{l}\text { Considerado na avaliação do franqueador: } \\
\text { Avaliação das sugestões de mudanças } \\
\text { propostas pelo franqueado } \\
\text { Total }\end{array}$ & $\begin{array}{l}\text { Não } \\
\text { Sim }\end{array}$ & $\begin{array}{r}9 \\
39,1 \% \\
14 \\
60,9 \% \\
23 \\
100,0 \%\end{array}$ & \begin{tabular}{r|}
6 \\
$16,7 \%$ \\
30 \\
$83,3 \%$ \\
36 \\
$100,0 \%$ \\
\end{tabular} & \begin{tabular}{r|}
15 \\
$25,4 \%$ \\
44 \\
$74,6 \%$ \\
59 \\
$100,0 \%$
\end{tabular} \\
\hline
\end{tabular}

Ao se realizar a prova de Kolmogorov-Smirnov (quadro 42), em relação ao índice de avaliação da inovação, conclui-se que, relativamente, os itens de inovação são mais presentes em franquias que definem objetivos e os acompanham $\left(\chi^{2}=8,987 ; \mathrm{p} \leq 0,05\right)$.

Quadro 43 - Define e acompanha objetivos por Dimensão inovação

\begin{tabular}{|c|c|c|c|c|c|c|c|}
\hline \multicolumn{4}{|c|}{ estrut def $=$ sem estrutura } & \multicolumn{4}{|c|}{ estrut def $=$ estruturada } \\
\hline avalia & & & & avalia & & & \\
\hline $\begin{array}{l}\text { aspecto } \\
\text { inovação }\end{array}$ & Freq. & Percentual & $\begin{array}{l}\text { Percentual } \\
\text { Acumulado }\end{array}$ & $\begin{array}{l}\text { aspecto } \\
\text { inovação }\end{array}$ & Freq. & Percentual & $\begin{array}{l}\text { Percentual } \\
\text { Acumulado }\end{array}$ \\
\hline 0 & 9 & 34,6 & 34,6 & 0 & 2 & 5,4 & 5,4 \\
\hline 1 & 5 & 19,2 & 53,8 & 1 & 4 & 10,8 & 16,2 \\
\hline 2 & 2 & 7,7 & 61,5 & 2 & 4 & 10,8 & 27 \\
\hline 3 & 4 & 15,4 & 76,9 & 3 & 6 & 16,2 & 43,2 \\
\hline 4 & 6 & 23,1 & 100 & 4 & 21 & 56,8 & 100 \\
\hline Total & 26 & 100 & & Total & 37 & 100 & \\
\hline
\end{tabular}

Nota-se que $56,8 \%$ das franquias ${ }^{45}$ que acompanham e definem objetivos (estruturada) têm todos os quesitos de inovação na avaliação, enquanto apenas $23,1 \%$ das outras franquias (sem estrutura) possuem tal índice.

Apresentam-se as variáveis em que não foi possível concluir pela dependência com a variável de definição de objetivos e acompanhamento no anexo II.

Em resumo, aquele grupo de franqueadores que definem objetivos para suas lojas franqueadas, e acompanham se tais objetivos são atingidos, apresentam uma avaliação mais freqüente em 28 dos 47 itens propostos avaliados, com significância estatística. Além disso, não se encontraram resultados que contradigam a segunda hipótese do estudo. Considerou-se também que dos 9 índices construídos para as diferentes dimensões propostas, 6 apresentaram associação com a variável proposta: operação/manutenção $\left(\chi^{2}=10,090\right)$, imagem da marca $\left(\chi^{2}=5,064\right)$, cliente $\left(\chi^{2}=7,101\right)$, logística $\left(\chi^{2}=5,589 ; \mathrm{p} \leq 0,10\right)$, relacionado à equipe $\left(\chi^{2}=\right.$

\footnotetext{
${ }^{45} \mathrm{O}$ calculo realizado para obter esse valor foi $100 \%-43,2 \%$ (quadro 43 ).
} 
$10,719)$ e inovação $\left(\chi^{2}=8,649\right)$. Sintetizaram-se os resultados obtidos na tabela de resultado 2.

Tabela de resultado 2 - Hipótese 2

\begin{tabular}{|ll|}
\hline Variável & Associação com: \\
\hline Definir e acompanhar & Define equipe para a avaliação \\
objetivos para os & Define módulos a serem estudados \\
franqueados & Definição de pesos para cada item pesquisado \\
& Constrói indicadores \\
& Integração dos resultados em módulos \\
& Sugestões de mudanças \\
& Revisão do sistema de avaliação \\
& Verifica o lucro da loja \\
& Verifica outros aspectos financeiros (não propostos) \\
& Verifica a manutenção do maquinário \\
& Verifica as condições do espaço físico \\
& Verifica a atualização tecnológica \\
Verifica as condições da fachada & Verifica o consumo de energia \\
Verifica as condições de higiene & Verifica a eficiência dos funcionários \\
Verifica a concorrência \\
Verifica a fidelização do cliente \\
Verifica o perfil do cliente \\
Verifica o atendimento ao cliente \\
Verifica o treinamento do franqueado \\
Verifica o treinamento do pessoal operacional \\
Verifica a identificação da equipe da loja com a marca \\
Verifica a participação em ações promocionais \\
Avalia as inovações propostas pelo franqueador. \\
Avalia as inovações criadas pelo franqueado. \\
Avalia as sugestões propostas pelo franqueado. \\
Associa-se também com 6 dos 9 índices propostos. \\
\hline $\begin{array}{l}\text { Conclusão: De forma geral, é possível afirmar que os franqueadores que definem } \\
\text { objetivos para os franqueados levantam dados e acompanham a execução dos } \\
\text { objetivos, revendo-os ao final do processo. Além disso, obtêm uma avaliação mais } \\
\text { consistente que o grupo, sem a preocupação com todas essas etapas. }\end{array}$ \\
\end{tabular}

Nesse sentido, conclui-se que os franqueadores que definem objetivos para as lojas franqueadas e acompanham o desenvolvimento desses objetivos realizam uma avaliação mais consistente do que os franqueadores que não o fazem, confirmando a segunda hipótese proposta no estudo. 


\subsubsection{Processos e resultados para a Hipótese 1 (3).}

A terceira hipótese formulada diz respeito ao tamanho da rede de lojas franqueadas. É natural imaginar que o tamanho da rede influencia a construção do processo de avaliação, e que quanto maior a rede de lojas franqueadas, mais estruturada é a avaliação realizada.

$H 1_{(3)}$ - Quanto maior a rede de franquias, mais consistente o sistema de avaliação.

Para responder a essa terceira hipótese, classificaram-se as franquias em dois grupos, utilizando-se como critério o número de lojas franqueadas:

- franqueadores com poucas lojas franqueadas ou, simplesmente, franquias pequenas aquelas com número de lojas franqueadas menor ou igual à mediana (17 lojas) da amostra.

- franqueadores com muitas lojas franqueadas ou, simplesmente, franquias grandes - aquelas com número superior que a mediana da amostra.

Um franqueador pode ter muitas lojas próprias e poucas lojas franqueadas; nesse caso, implica a classificação desse franqueador como uma franquia pequena. Optou-se por esse critério porque o foco do estudo é entender as implicações para as redes com muitos franqueados, e não com muitas lojas.

Após a separação em grupos, procedeu-se à sua comparação através dos testes estatísticos. Primeiramente, realizou-se o teste Qui-Quadrado para variáveis nominais, com o objetivo de comparar as amostras, classificadas por tamanho, quanto à porcentagem de presença das diversas características propostas no questionário.

Em relação às etapas propostas para o processo de avaliação, rejeitou-se a prova de independência, sendo observada maior presença dos seguintes itens nas franquias com redes maiores de lojas franqueadas:

- definição da equipe responsável pela avaliação: nas grandes franquias, relativamente a presença desse item de avaliação é maior (90,3\% ante 71,9\% nas pequenas franquias);

- definição das dimensões/módulos a serem estudados. (financeiro, recursos humanos, clientes $)-(83,9 \%$ contra $65,6 \%)$;

- definição dos pesos e critérios para cada item pesquisado (77,4\% contra 46,9\%). 
Cabe analisar que o item relativo à definição da equipe seria esperável, pois há provavelmente em redes maiores, um maior número de pessoas trabalhando na franqueadora. As outras duas etapas sinalizam que os franqueadores com redes maiores utilizam com mais frequiência conceitos presentes nos modelos mais atuais de avaliação, conforme a revisão bibliográfica, com a construção de indicadores e definição de módulos. Esse fato provavelmente associa-se a uma melhor formação profissional dos gestores das maiores redes. Os quadros 44 a 46 resumem os resultados.

Quadro 44 - Tamanho da rede por Etapa definição da equipe.

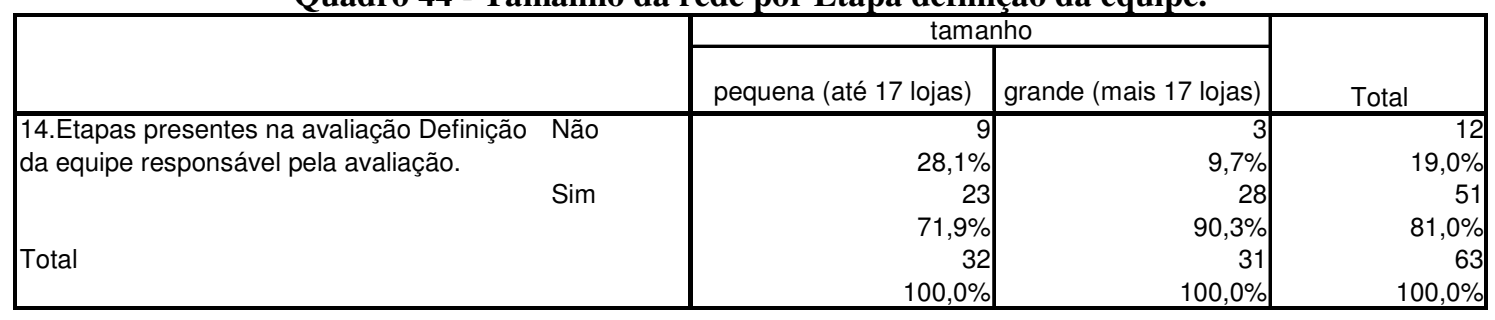

$\chi^{2}=3,475 ; p=0,062$

Quadro 45 - Tamanho da rede por Etapa definição dos módulos

\begin{tabular}{|l|r|r|r|}
\hline & \multicolumn{2}{|c|}{ tamanho } \\
\cline { 2 - 3 } & pequena (até 17 lojas) & grande (mais 17 lojas) & Total \\
\hline 17. Etapas presentes na avaliação Definição Não & 11 & 5 & 16 \\
das dimensões/módulos a serem estudados. & $34,4 \%$ & $25,1 \%$ & $2 \%$ \\
(financeiro, recursos humanos, clientes, etc.) Sim & 21 & 26 & $83,9 \%$ \\
& $47,6 \%$ & 31 \\
Total & 32 & $74,6 \%$ \\
& 63 & $100,0 \%$ & $100,0 \%$ \\
\hline
\end{tabular}

$\chi^{2}=2,767 ; p=0,096$

Quadro 46 - Tamanho da rede por Etapa definição dos pesos dos itens

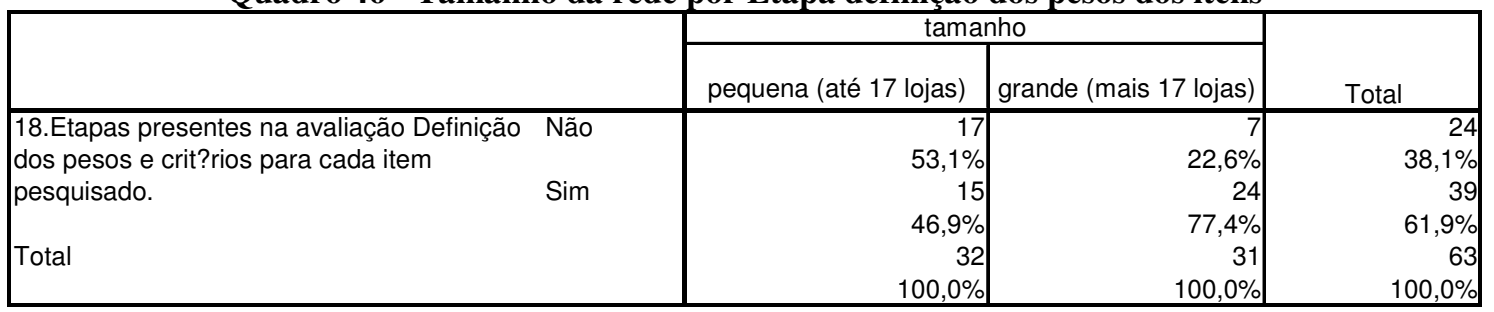

$\chi^{2}=6,229 ; p=0,013$

Em relação aos aspectos financeiros e de vendas propostos, não houve qualquer variável com associação significativa relacionada ao tamanho da rede de lojas franqueadas. Ou seja, cada característica dos módulos financeiro e vendas proposta, na avaliação realizada pelo franqueador nas lojas franqueadas, isoladamente, têm o mesmo comportamento em relação à sua presença ou ausência, qualquer que seja o tamanho da rede de franquias. 
Em relação aos aspectos propostos no módulo operacional, houve associação significativa do número de lojas franqueadas, com os seguintes itens (os quadros 47 a 49 apresentam as associações encontradas):

- manutenção do maquinário/equipamento da loja (73,3\% para as redes maiores ante 48,3\% para as redes com poucas lojas);

- condições ou manutenção do espaço físico (93,3\% ante 65,5\%);

- condições de higiene na loja (96,7\% ante $65,5 \%)$.

Quadro 47 - Tamanho da rede franqueada por Manutenção do equipamento

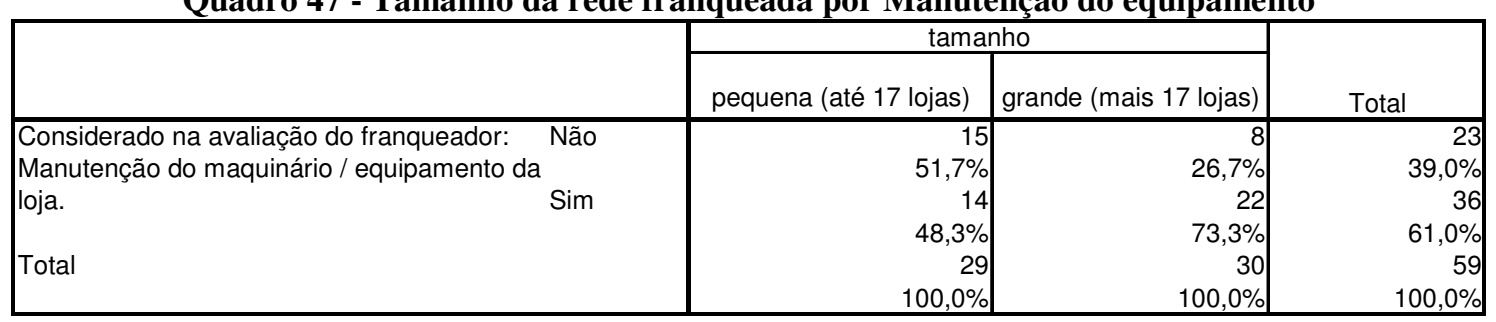

$\chi^{2}=3,892 ; p=0,049$

Quadro 48 - Tamanho da rede franqueada por Condições do espaço físico

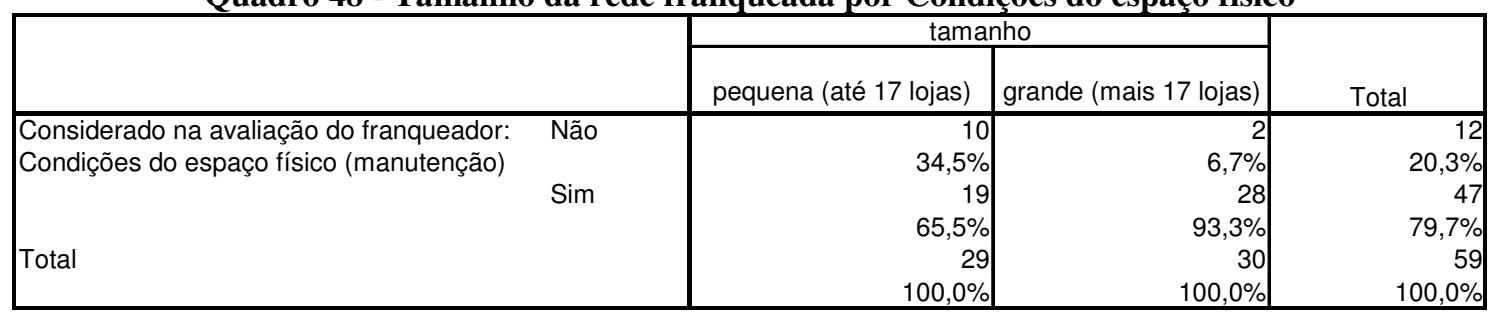

$\chi^{2}=7,042 ; p=0,008$

Quadro 49 - Tamanho da rede franqueada por Higiene na loja

\begin{tabular}{|c|c|c|c|c|}
\hline & \multicolumn{2}{|c|}{ tamanho } & \multirow[b]{2}{*}{ Total } \\
\hline & & pequena (até 17 lojas) & grande (mais 17 lojas) & \\
\hline \multirow{4}{*}{$\begin{array}{l}\text { Considerado na avaliação do franqueador } \\
\text { Condições de Higiene na loja }\end{array}$} & Não & 10 & 1 & 11 \\
\hline & & $34,5 \%$ & $3,3 \%$ & $18,6 \%$ \\
\hline & Sim & 19 & 29 & 48 \\
\hline & & $65,5 \%$ & $96,7 \%$ & $81,4 \%$ \\
\hline \multirow{2}{*}{\multicolumn{2}{|c|}{ Total }} & 29 & 30 & \\
\hline & & $100,0 \%$ & $100,0 \%$ & $100,0 \%$ \\
\hline
\end{tabular}

$\chi^{2}=9,433 ; p=0,002$

Em relação ao módulo criado para avaliar aspectos relativos à imagem da marca, encontraram-se duas associações. Com relação às condições de higiene na loja, já se apresentou o item no quadro 49, pois também faz parte do módulo operacional. O quadro 50 apresenta os dados das condições de fachada:

- condições da fachada/vitrine $(96,7 \%$ ante $75,9 \%)$;

- condições de higiene na loja (96,7\% ante $65,5 \%)$; 
Quadro 50 - Tamanho da rede franqueada por Condições da fachada

\begin{tabular}{|ll|r|r|r|}
\hline & & \multicolumn{2}{|c|}{ tamanho } & \\
\cline { 3 - 5 } & & pequena (até 17 lojas) & grande (mais 17 lojas) & Total \\
\hline Considerado na avaliação do franqueador: & Não & 7 & 1 & 8 \\
Condições da fachada / vitrine & & $24,1 \%$ & $3,3 \%$ & $13,6 \%$ \\
& \multirow{2}{*}{ Sim } & 22 & 29 & 51 \\
Total & & $75,9 \%$ & $86,4 \%$ \\
& & 29 & $56,7 \%$ & 30 \\
\hline
\end{tabular}

Prova de Fisher; $\mathrm{p}=0,026$

Em relação ao módulo relativo à equipe, encontrou-se apenas um item em que ocorre associação:

- eficiência dos funcionários da loja (100\% ante 82,8\%);

Quadro 51 - Tamanho da rede franqueada por Eficiência equipe

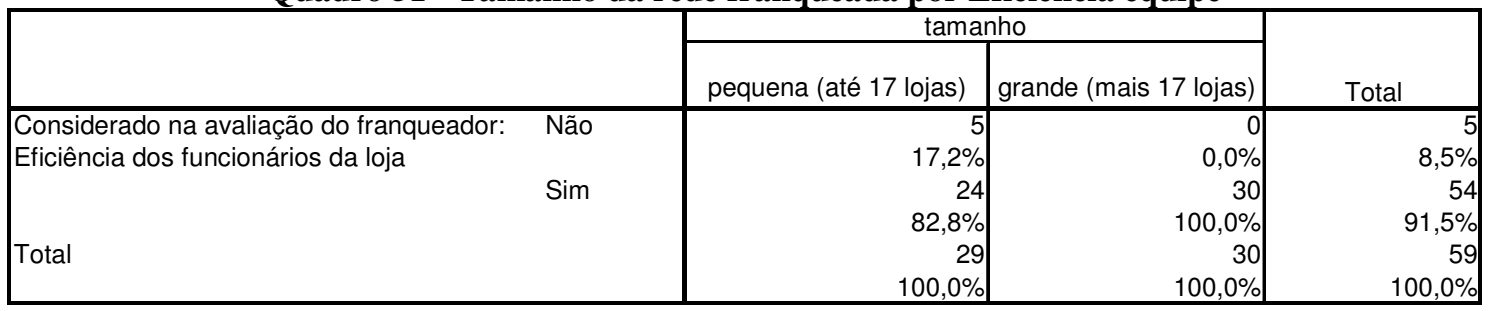

Prova de Fisher; $p=0,024$

Em relação aos aspectos propostos nos módulos clientes, de logística e de inovação, não houve qualquer variável (neste estudo) desses aspectos com associação significativa com o tamanho da rede de franquias. Pode-se afirmar, assim, que a presença ou ausência dos itens de avaliação de clientes, logística e inovação independem do tamanho da rede de lojas franqueadas.

Observou-se a relação entre o número de lojas franqueadas na rede, e alguns dos itens relativos a avaliar o relacionamento do franqueado com a rede e com os parceiros, a saber:

- participação da loja em ações sociais promovidas pela rede: $63,3 \%$ ante $34,5 \%$;

- participação do franqueado nos debates dos grupos dos franqueados: 70,0\% ante 41,4\%.

Os quadros 51 e 52 apresentam os resultados encontrados e os valores do teste de QuiQuadrado. 
Quadro 52 - Tamanho da rede e participação em Ações sociais

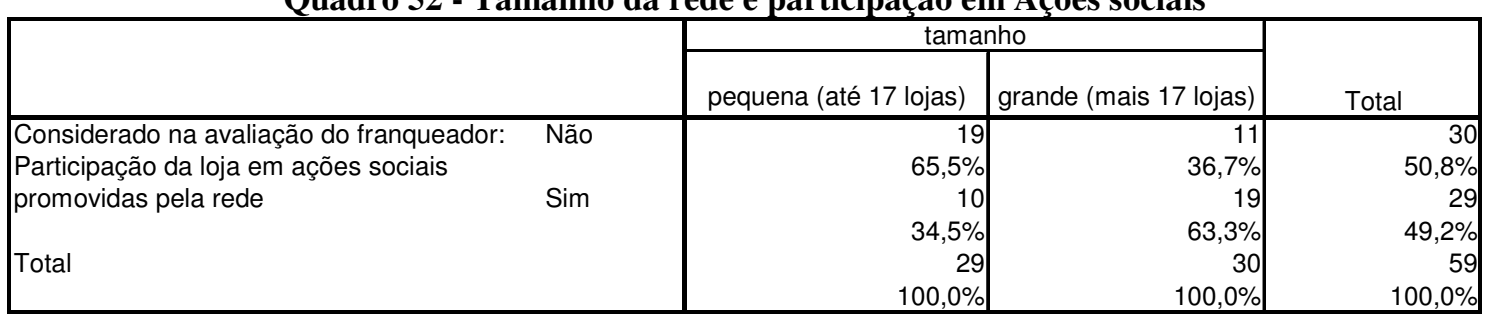

$\chi^{2}=4,911 ; p=0,027$

Quadro 53 - Tamanho da rede e Participação nos grupos de franqueados

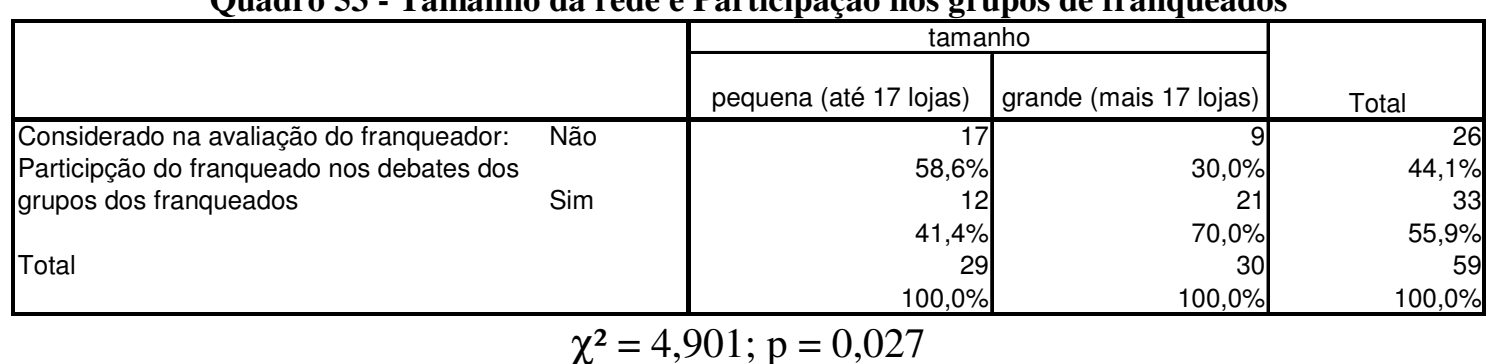

As diversas variáveis não binárias em que se concluiu pela independência com relação ao número de lojas franqueadas estão no anexo III. Entre os índices propostos para os módulos, aqueles relativos à vendas, finanças, operação, equipe, cliente, inovação mostraram-se também independentes, na prova de Kolmogorov-Smirnov, conforme anexo III.

Quanto à imagem de marca e aspecto de parceiros, rejeitou-se a hipótese de igualdade entre pequenas e grandes franquias (imagem de marca $\left(\chi^{2}=9,785 ; p \leq 0,05\right)$ e parceiros $\left(\chi^{2}=5,684\right.$; $\mathrm{p} \leq 0,05)$, a favor da hipótese de maior rede de franquias avaliação mais complexa. De forma analítica, nas grandes franquias, 61,3\% dos respondentes têm todos os itens de avaliação de imagem de marca, enquanto nas pequenas franquias isso ocorre em apenas $21,9 \%$ dos casos. Em relação ao módulo que verifica avaliação da relação com os parceiros, 68,8\% das pequenas franquias têm até 3 itens de avaliação, enquanto que nas grandes franquias esse percentual só atinge $39 \%$, pois a sua maioria tem mais do que 3 itens de avaliação de parceria.

A seguir, procedeu-se à análise da relação entre o tamanho das redes de franquias e as variáveis ordinais. Pela Prova de Kolmogorov-Smirnov, não se detectou qualquer diferença quanto às variáveis levantadas, entre as amostras de franquias pequenas e grandes.

Finalmente, analisaram-se as relações entre o tamanho da rede e as variáveis intervalares. Apenas para confirmar, a Prova de Man-Whitney aponta diferença entre pequenas e grandes redes de lojas franqueadas quanto ao número de total de lojas, o que é evidente $(p=0,000)$. 
Também em relação ao tempo que a marca começou a operar com sistema de franquias, a prova concluiu a diferença entre as duas amostras: franquias com mais franqueados têm mais tempo de exercício, o que é esperado.

\section{Quadro 54 - Tamanho da rede e Tempo de existência}

\begin{tabular}{|c|c|c|c|c|}
\hline & tamanho & $\mathrm{N}$ & $\begin{array}{c}\text { Média de } \\
\text { postos }\end{array}$ & $\begin{array}{c}\text { Soma de } \\
\text { postos }\end{array}$ \\
\hline tempo & $\begin{array}{l}\text { pequena (até } 17 \text { lojas) } \\
\text { grande (mais } 17 \text { lojas) } \\
\text { Total }\end{array}$ & \begin{tabular}{l|}
32 \\
31 \\
63
\end{tabular} & \begin{tabular}{|l|}
25,53 \\
38,68
\end{tabular} & $\begin{array}{r}817,00 \\
1.199,00\end{array}$ \\
\hline
\end{tabular}

$\mathrm{U}=289,00 ; \mathrm{z}=-2,856, \mathrm{p}=0,004$

Em termos de investimento inicial para abrir uma loja padrão e tempo de retorno do investimento, não foi possível encontrar qualquer diferença entre os tamanhos das redes de franquias (pela Prova de Mann-Whitney: $p=0,445$ e $p=0,177$, respectivamente).

Em relação à terceira hipótese proposta, observaram-se 7 itens entre os 47 sugeridos em que ocorre diferenças entre as redes com mais lojas franqueadas e as redes com menor número de lojas franqueadas. A maioria desses itens são relativos à operação da unidade e, realmente, para essa dimensão, há diferença entre a avaliação realizada pelas franquias com mais lojas franqueadas das com menos, apesar de não haver diferença para o índice que mede o módulo operação (em si). Sobre os aspectos do módulo marca, também há uma preocupação maior em avaliá-los. Uma explicação simples para esse fato é que quanto maior uma rede, mais valor tem sua marca (AMBLER et. al., 2002), e mais a perder se esses aspectos forem negligenciados.

Os outros dois itens, relativos à avaliação do módulo da relação com parceiros, mostram diferença no aspecto participação social, o que talvez se justifique porque redes menores podem não realizar muitas ações desse tipo (uma sugestão para estudos futuros). $\mathrm{O}$ outro item é relativo à participação nos grupos de franqueados; é provável que os franqueados com poucas lojas nem mesmo tenham grupos de franqueados (como o comitê de publicidade, que define em que se investe a verba de publicidade), portanto pouco se pode dizer sobre isso.

As outras características da avaliação não são dependentes do tamanho da rede de franquias; não foi possível rejeitar a hipótese de nulidade (H0). A Tabela de resultado 3 resume os achados: 
Tabela de resultado 3 - Hipótese 3

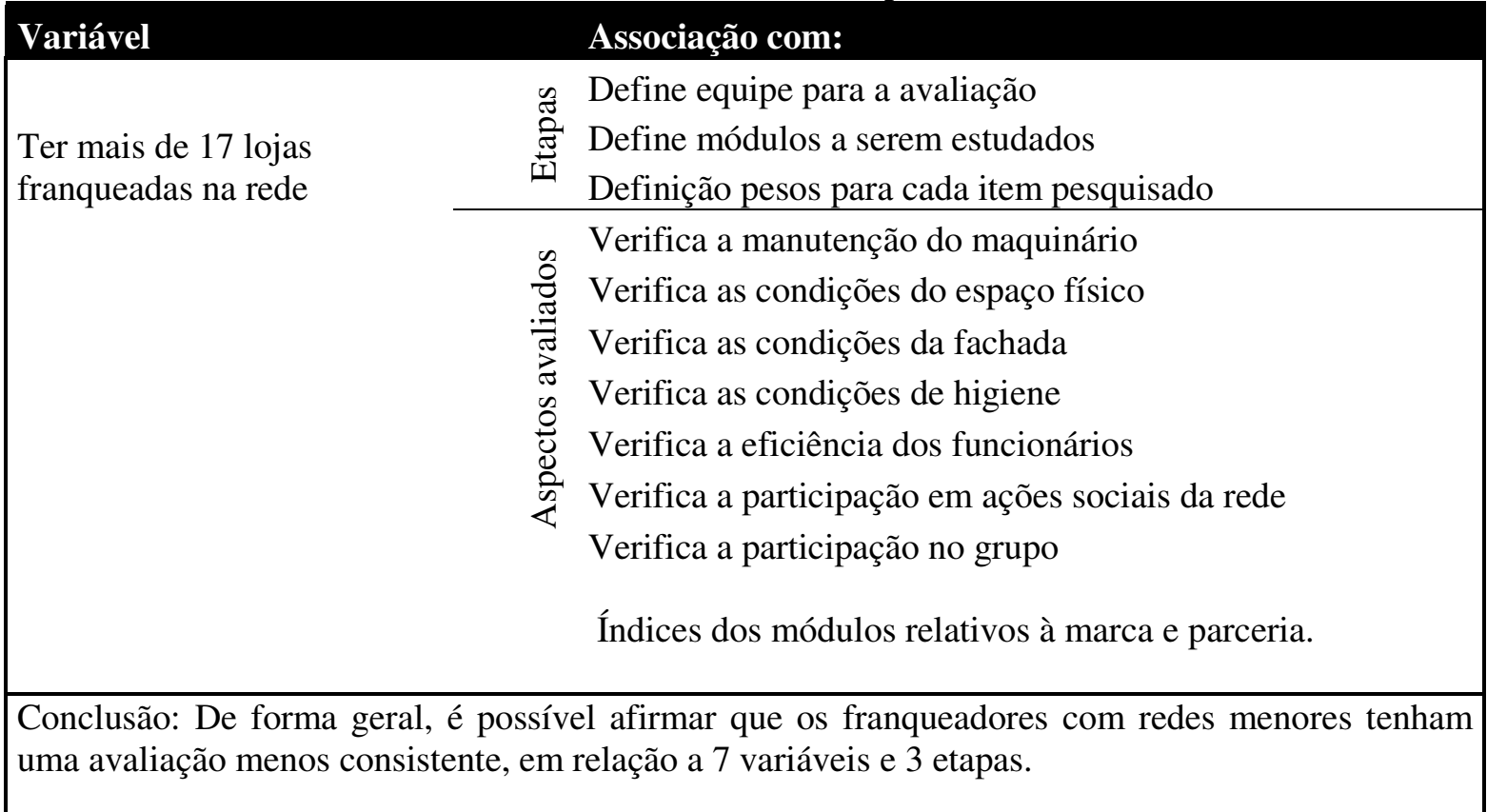

\subsubsection{Processos e resultados para a Hipótese 1 (índice 4).}

Finalmente, formulou-se uma última hipótese no mesmo sentido da anterior, relacionando a idade das franquias à avaliação. Também é possível que para diferentes idades de franquia, a avaliação realizada seja diferente (teste bicaudal).

$\mathrm{H} 1_{(4)}$ - Em franquias novas ou antigas, a avaliação efetuada é diferente.

H0(4) - Em franquias novas ou antigas a avaliação efetuada é semelhante.

Para se responder a essa terceira hipótese, classificaram-se as franquias em dois grupos, utilizando como critério o número de anos em que a marca iniciou a operação com franquias:

- franquias novas - aquelas com número de lojas franqueadas menor ou igual à mediana (até 7 anos);

- franquias antigas - aquelas com número maior que a mediana da amostra.

Também, nesse caso, preferiu-se o início da operação com franquias em detrimento do início da operação da franqueadora, pois o interesse é específico no sistema. Assim, uma empresa que exista há mais de 10 anos, mas tenha iniciado o sistema de franquias há 2 anos, será considerada, uma franquia nova. 
Após a classificação, procedeu-se a comparação dos grupos através dos testes estatísticos. Primeiramente realizou-se o teste Qui-Quadrado para variáveis nominais, com o objetivo de comparar as amostras, classificadas por idade, quanto à porcentagem de presença das diversas características propostas no questionário.

Em relação às etapas propostas para o processo de avaliação, rejeitou-se a prova de independência, observando-se maior presença dos itens listados, nas franquias mais velhas.

Em relação a Processos Judiciais de terceiros contra a loja/franqueado, relativamente, é mais presente na avaliação de antigas franquias (42,9\% ante $12,9 \%$ nas franquias mais novas)

Quadro 55 - Tempo de existência e Verificação judicial

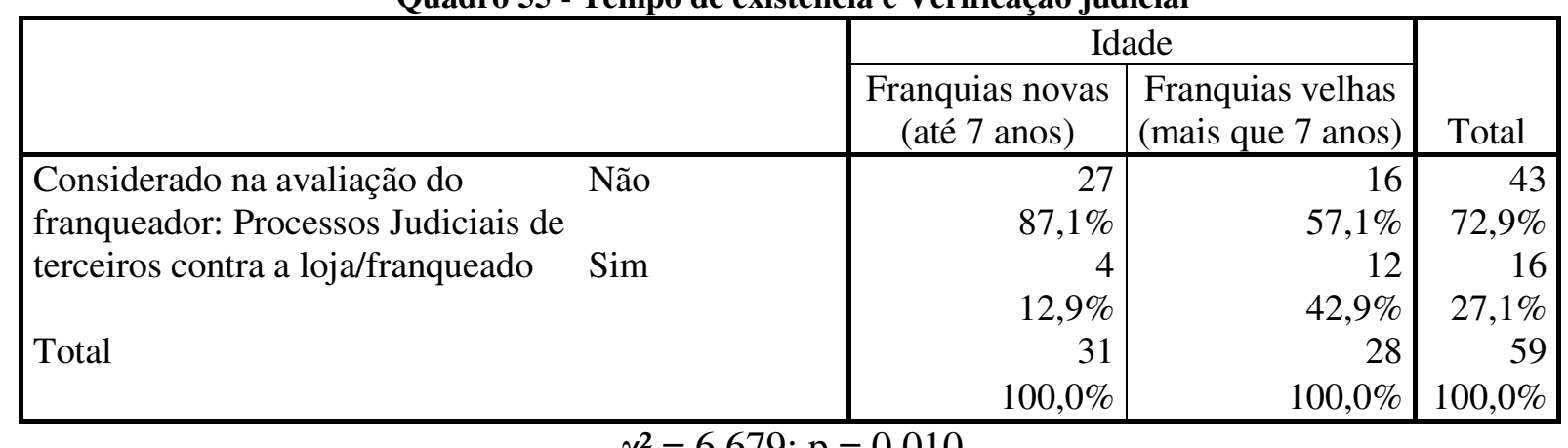

Em relação às outras características nominais, não foi possível rejeitar a hipótese de independência entre as variáveis e a variável de classificação por idade da franquia.

Quanto às variáveis intervalares, através da Prova de Mann-Whitney, conclui-se que:

Quadro 56 - Tempo de existência e Número de lojas

\begin{tabular}{|c|c|c|c|c|c|c|}
\hline & Idade & $\mathrm{N}$ & $\begin{array}{l}\text { Média } \\
\text { do posto }\end{array}$ & $\begin{array}{c}\text { Soma de } \\
\text { Postos }\end{array}$ & $\begin{array}{l}\text { Estatística } \\
\text { do teste }\end{array}$ & $\begin{array}{c}\text { Nível } \\
\text { descritivo } \\
\text { (p) }\end{array}$ \\
\hline $\begin{array}{l}\text { 2. Quantas lojas operam } \\
\text { com a sua marca? }\end{array}$ & $\begin{array}{l}\text { franquias novas (até } 7 \text { anos) } \\
\text { franquias velhas (mais que } \\
7 \text { anos) } \\
\text { Total }\end{array}$ & $\begin{array}{l}33 \\
30 \\
63\end{array}$ & $\begin{array}{l}25,89 \\
38,72\end{array}$ & $\begin{array}{c}854,50 \\
1.161,50\end{array}$ & 295,500 & 0,006 \\
\hline $\begin{array}{l}\text { 3. Destas, quantas são } \\
\text { lojas franqueadas? }\end{array}$ & $\begin{array}{l}\text { franquias novas (até } 7 \text { anos) } \\
\text { franquias velhas (mais que } \\
7 \text { anos) } \\
\text { Total }\end{array}$ & $\begin{array}{l}33 \\
30 \\
63\end{array}$ & $\begin{array}{l}25,24 \\
39,43\end{array}$ & $\begin{array}{c}833,00 \\
1.183,00\end{array}$ & 272,000 & 0,002 \\
\hline
\end{tabular}


As redes mais antigas no franchise operam com maior número de lojas do que as mais novas, sejam estas unidades franqueadas ou próprias.

Quanto às variáveis ordinais, através da Prova de Kolmogorov-Smirnov, não foi possível rejeitar a hipótese de igualdade entre as amostras, qualquer que seja a variável ou índice elaborado, ao nível de significância de 5\%.

Em resumo, para a hipótese proposta, há apenas um item que se relaciona à idade da operação com franquias, na análise de variáveis binárias. O item em que as franquias diferem faz sentido, pois os franqueadores mais antigos são mais cautelosos com os novos franqueados, verificando processos judiciais com uma freqüência maior. Formula-se outra sugestão para um trabalho futuro: verificar se os franqueadores mais antigos atuam de maneira menos acessível com os franqueados e, por outro lado, mais profissional, como indica esse achado.

De modo geral, há poucas diferenças nos processos de avaliação que possam se relacionar ao tempo de atuação com franquias.

\subsubsection{Estudo de dependência entre os índices}

Como último procedimento, realizou-se o estudo de dependência entre os diversos grupos construídos, a fim de testar as hipóteses $\mathrm{H} 1, \mathrm{H} 2, \mathrm{H} 3$ e H4. Recorda-se que se separaram os grupos de franqueadores, considerando os que possuem processo de avaliação estruturado em objetivos, aqueles que apresentavam todas as etapas, a seguir, em seu processo de avaliação:

- definição de objetivos a serem atingidos;

- definição dos dados coletados;

- levantamento de dados;

- comparação dos resultados obtidos com esperados e relatório final;

- revisão dos objetivos.

Consideraram-se também franqueadores remunerados através de royalty, e outro grupo, remunerado exclusivamente através de taxa fixa. 
Também se segmentaram os grupos em franqueadores com redes de até 17 lojas franqueadas, e franqueadores com uma rede maior de lojas.

Além disso, separaram-se os franqueadores por idade de atuação no sistema de franquias. Utilizou-se a 7 anos de atuação com franquias (mediana da amostra) como linha divisória entre novas e antigas franquias.

\subsubsection{Cinco hipóteses relativas aos índices}

Com relação a essas características, inicialmente se buscou saber se a utilização de um tipo de cobrança (por royalty ou por taxa fixa) relaciona-se ao tamanho da rede e, principalmente, dado o propósito deste estudo, a uma avaliação que defina objetivos para os franqueados e acompanhe sua consecução, aqui descrita como avaliação estruturada. Logo, elaborou-se a quinta hipótese do estudo.

H1 $1_{(5)}$ : Há dependência entre o tipo de pagamento realizado pelo franqueador e o tamanho da rede de franquias.

H0 (5): Não há dependência entre o tipo de pagamento realizado pelo franqueador e o tamanho da rede.

Simultaneamente, elaborou-se a sexta hipótese do estudo.

$\mathrm{H} 1_{(6)}$ : Há dependência entre o tipo de pagamento realizado pelo franqueador e o fato do franqueador apresentar ou não as etapas relacionadas a uma avaliação estruturada em objetivos.

H0 (6): Não há dependência entre o tipo de pagamento realizado pelo franqueador e o fato do franqueador apresentar ou não as etapas que compõem o índice "define e acompanha objetivos."

Para a Hipótese $\mathrm{H}_{(5)}$ procedeu-se à prova estatística através do teste de Qui-quadrado. Descobriu-se, porém, que não há associação entre tipo de pagamento e tamanho de rede de franquias $\left(\chi^{2}=0,134 . p=0,714\right)$, conforme o quadro 57 . 
Procedeu-se, para a Hipótese $\mathrm{H}_{(6)}$, à prova estatística através do teste de Qui-quadrado. Descobriu-se, porém, que tampouco há associação entre tipo de pagamento e uma avaliação estruturada para objetivos nas franquias $\left(\chi^{2}=0,512 . p=0,474\right)$, conforme o quadro 58

Quadro 57 - Relação entre Tipo de remuneração e Tamanho da rede.

\begin{tabular}{|c|c|c|c|c|}
\hline & \multicolumn{2}{|c|}{ tamanho } & \multirow[b]{2}{*}{ Total } \\
\hline & & pequena (até 17 lojas) & grande (mais 17 lojas) & \\
\hline $\begin{array}{l}\text { 10. Como o franqueador é } \\
\text { remunerado: Royalts } \\
\text { (porcentagem do faturamento } \\
\text { ou do resultado). } \\
\text { Total }\end{array}$ & $\begin{array}{l}\text { Não } \\
\text { Sim }\end{array}$ & $\begin{array}{r}7 \\
21,9 \% \\
25 \\
78,1 \% \\
32 \\
100,0 \%\end{array}$ & $\begin{array}{r}8 \\
25,8 \% \\
23 \\
74,2 \% \\
31 \\
100,0 \%\end{array}$ & $\begin{array}{r}15 \\
23,8 \% \\
48 \\
76,2 \% \\
63 \\
100,0 \%\end{array}$ \\
\hline
\end{tabular}

Quadro 58 - Tipo de remuneração e Definição e acompanhamento de objetivos.

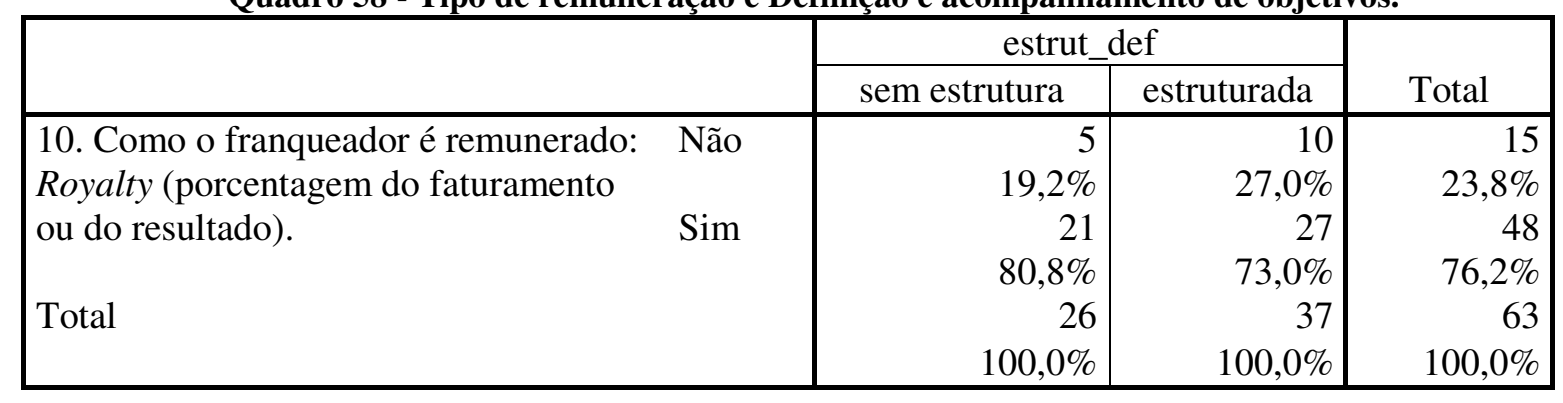

A sétima e a oitava hipóteses do estudo buscaram saber se o tamanho da rede relaciona-se à sua idade e, principalmente, dado o propósito deste estudo, a uma avaliação que defina objetivos para os franqueados e acompanhe sua consecução, aqui descrita como avaliação estruturada. Dessa forma, elaborou-se a sétima hipótese do estudo.

$H 1_{(7)}$ : Há associação entre o tamanho da rede e o fato de o franqueador apresentar ou não as etapas relacionadas a uma avaliação estruturada em objetivos.

$\mathrm{H}_{(7)}$ : Há independência entre o tamanho da rede e o fato de o franqueador apresentar ou não as etapas relacionadas a uma avaliação estruturada em objetivos.

Procedeu-se à prova estatística para a hipótese 7. Pela Prova do Qui-quadrado, pode-se concluir a dependência entre tamanho da franquia e uma avaliação estruturada $\left(\chi^{2}=3,771\right.$. $p=$ 0,052). Grandes franquias têm maior proporção de franquias que definem objetivos, acompanham sua execução, comparam os resultados e revêem os objetivos. Não foi possível aceitar H0, portanto a hipótese 7 foi aceita. 
Quadro 59 - Define e acompanha objetivos por Tamanho da rede.

\begin{tabular}{|c|c|c|c|}
\hline & \multicolumn{2}{|c|}{ tamanho } & \multirow[b]{2}{*}{ Total } \\
\hline & pequena (até 17 lojas) & grande (mais 17 lojas) & \\
\hline \multirow[t]{2}{*}{ estrut_def sem estrutura } & 17 & 9 & 26 \\
\hline & $53,1 \%$ & $29,0 \%$ & $41,3 \%$ \\
\hline \multirow[t]{2}{*}{ estruturada } & 15 & 22 & 37 \\
\hline & $46,9 \%$ & $71,0 \%$ & $58,7 \%$ \\
\hline \multirow[t]{2}{*}{ Total } & 32 & 31 & 63 \\
\hline & $100,0 \%$ & $100,0 \%$ & $100,0 \%$ \\
\hline
\end{tabular}

Observa-se que $71 \%$ das grandes franquias apresentam a avaliação estruturada, enquanto tal índice é de 46,9\% nas franquias pequenas, conforme o quadro 59.

Assim como a hipótese 3, a confirmação da hipótese 7 ajuda a reforçar a idéia de que as grandes redes têm um processo de avaliação de acordo com as teorias propostas pelos modelos prescritivos. Isso pode significar que esses modelos sejam efetivos e redes que os utilizam tornem-se maiores, ou apenas que as grandes redes construam seus sistemas tendo esses modelos em mente (mais do que as pequenas redes).

Espera-se que as franquias atuando há mais tempo sejam maiores. Formulou-se também a oitava hipótese do estudo.

$\mathrm{H} 1_{(8)}$ : Há associação entre o tamanho da rede e a idade da rede.

$\mathrm{HO}_{(8)}$ : Há independência entre o tamanho da rede e a idade da rede.

Em seguida procedeu-se a prova estatística. Há dependência entre tamanho da franquia e seu tempo de existência: as grandes redes de franquias têm maior proporção de franquias com mais tempo de existência, o que era esperável, conforme o quadro $60\left(\chi^{2}=4,573\right.$. $\left.p=0,032\right)$.

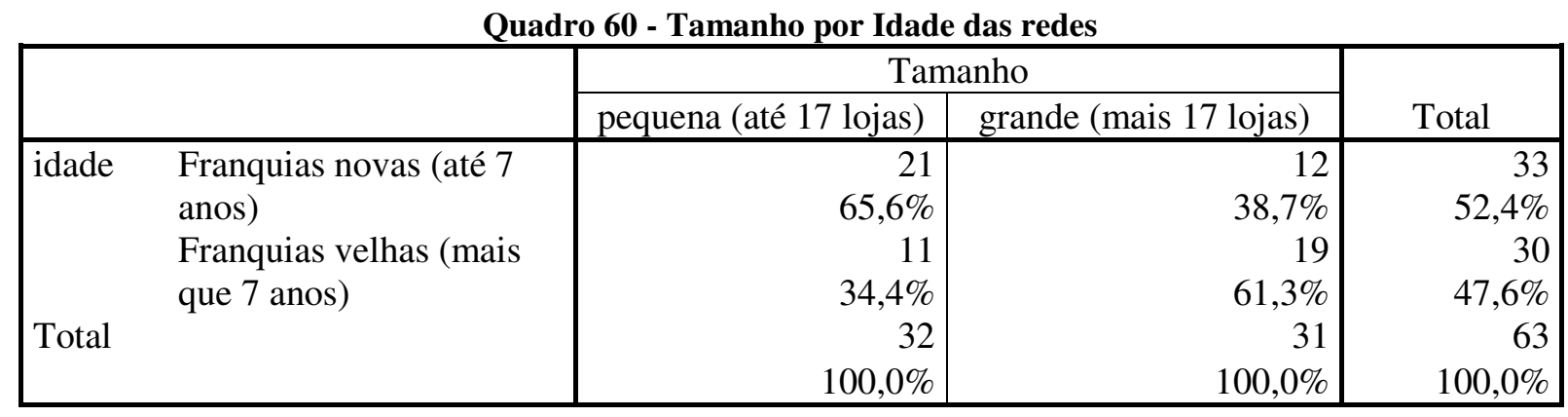


Espera-se que as franquias atuando há mais tempo contemplem um sistema de avaliação que proponha objetivos e acompanhe seus resultados revendo-os com mais frequiência que as mais novas. Formulou-se ainda a nona hipótese do estudo:

H1 $1_{(9)}$ : Há associação entre o tamanho da rede e o fato de o franqueador apresentar ou não as etapas relacionadas a uma avaliação estruturada em objetivos.

$\mathrm{HO}_{(9)}$ : Há independência entre o tamanho da rede e o fato de o franqueador apresentar ou não as etapas relacionadas a uma avaliação estruturada em objetivos.

Realizou-se a prova estatística. É intrigante não haver associação $\left(\chi^{2}=0,501 \cdot p=0,479\right)$ entre o tempo em que uma rede opera com franquias e uma avaliação que contempla todas as etapas relativas a objetivos (definição de objetivos, definição e coleta de dados, análise dos resultados, revisão dos objetivos), conforme o quadro 61.

\begin{tabular}{|c|c|c|c|c|}
\hline & Quadro 61 - Idade da rede por Define e acompanha objetivos & estrut & & \\
\hline & & sem estrutura & estruturada & Total \\
\hline idade & $\begin{array}{l}\text { franquias novas (até } 7 \\
\text { anos) } \\
\text { franquias velhas (mais que } \\
7 \text { anos) }\end{array}$ & $\begin{array}{r}15 \\
57,7 \% \\
11 \\
42,3 \%\end{array}$ & \begin{tabular}{r|}
18 \\
$48,6 \%$ \\
19 \\
$51,4 \%$
\end{tabular} & $\begin{array}{r}33 \\
52,4 \% \\
30 \\
47,6 \%\end{array}$ \\
\hline Total & & $\begin{array}{r}26 \\
100,0 \% \\
\end{array}$ & $\begin{array}{r}37 \\
100,0 \%\end{array}$ & $\begin{array}{r}63 \\
100,0 \%\end{array}$ \\
\hline
\end{tabular}

Aparentemente, a idade de atuação com franquias não conduz necessariamente a um sistema de avaliação mais consistente, contrariando as expectativas relativas ao aprendizado do franqueador. Explicação alternativa pode ser a aplicação por novos franqueadores de sistemas descritos na literatura, ou seja, os novos franqueadores, ao iniciarem sua operação, já utilizam as recomendações mais atuais.

Finalmente, construiu-se uma última hipótese. O estudo procurou verificar se as práticas recomendáveis em um processo de avaliação, utilizadas para separação do grupo de franqueadores como aqueles que fazem uma avaliação estruturada, resultaram em melhores resultados quanto ao crescimento da rede para o franqueador. Formulou-se, assim, a décima hipótese do estudo: 
H1(10): Há maior taxa de crescimento da rede de franquias naquelas que definem, revêem e acompanham a execução de objetivos.

H0(10): O crescimento da rede de franquias que definem, revêem e acompanham a execução de objetivos é igual ao daquelas que não o fazem.

A fim de verificar o resultado da décima hipótese proposta, construiu-se um índice que avalia a taxa de crescimento da franquia, conforme a fórmula:

Taxa de crescimento $=\frac{\text { Número de lojas hoje }- \text { Número de lojas no passado }}{\text { Número de lojas no passado }}$

Para o número de lojas no passado, utilizaram-se dois valores, fornecidos pelos franqueadores, relativos aos anos de 2003 e 2006.

Procedeu-se, assim, à prova de Mann-Whitney e, como resultado, não houve diferença entre as amostras, sendo impossível rejeitar $\mathrm{H} 0{ }_{(10)}$, conforme o quadro 62 :

Quadro 62 - Independência entre crescimento e Avaliação estruturada

\begin{tabular}{|l|l|}
\hline Ano & Avaliação estruturada para objetivos \\
\hline 2003 à 2008 & $\mathrm{p}=0,348$ \\
\hline 2006 à 2008 & $\mathrm{p}=0,215$ \\
\hline
\end{tabular}

Conclui-se, dessa forma, que os franqueadores que aplicaram uma avaliação de acordo com a revisão bibliográfica não tiveram desempenho em crescimento da rede significativamente superior aos outros franqueadores no período proposto. Há três explicações para esse fato: primeiro, deve-se notar que o crescimento de uma rede é resultado de uma série de fatores, e realizar uma avaliação consistente pode ser um fator de pouco peso, em relação ao conjunto total de influência. Além disso, uma rede pode crescer rapidamente, por uma política agressiva de vendas, por exemplo, mas apresentar resultados negativos em uma análise de mais longo prazo. Finalmente, pode-se questionar se as redes estudadas apresentavam sistemas de avaliação com as características levantadas neste estudo já em 2003, ou mesmo em 2006, sendo portanto difícil vincular os resultados obtidos aos sistemas utilizados. Uma última sugestão para estudos futuros é verificar se esses índices de crescimento mudarão, em períodos futuros, possivelmente em decorrência dos sistemas de avaliação utilizados hoje. 
Tabela de resultado 4 - Hipóteses 5 até 9

\begin{tabular}{|cll|}
\hline Hipóteses & Variável & Associação: \\
\hline 5 & Tipo de pagamento & $\begin{array}{l}\text { Não foi possível encontrar associação com o tamanho da } \\
\text { rede }\end{array}$ \\
\hline 6 & Tipo de pagamento & $\begin{array}{l}\text { Não se associa com o franqueador apresentar as etapas } \\
\text { relacionadas a uma avaliação estruturada em objetivos }\end{array}$ \\
\hline 8 & Tamanho da rede & $\begin{array}{l}\text { Associa-se ao franqueador apresentar etapas relacionadas a } \\
\text { uma avaliação estruturada em objetivos }\end{array}$ \\
\hline 9 & Tamanho da rede & Associa-se à idade da rede. \\
\hline 10 & $\begin{array}{l}\text { O dade da rede } \\
\text { apresenta as etapas } \\
\text { relacionadas a uma } \\
\text { avaliação estruturada } \\
\text { em objetivos }\end{array}$ & $\begin{array}{l}\text { Não se associa a um maior crescimento da rede em número } \\
\text { relacionadas a uma avaliação estruturada em objetivos }\end{array}$ \\
\hline $\begin{array}{l}\text { Conclusões: De forma geral, é possível confirmar que, em comparação com as redes menores, a } \\
\text { avaliação realizada pelas redes maiores é mais consistente. É possível afirmar também que os } \\
\text { franqueadores que definem objetivos para os franqueados, levantam dados e acompanham a a } \\
\text { execução dos objetivos, revendo-os ao final do processo têm uma avaliação mais consistente. }\end{array}$ \\
\hline
\end{tabular}

No próximo capítulo apresentam-se as conclusões do trabalho. 


\section{CONCLUSÕES.}

\section{$\underline{5.1 \text { Conclusões }}$}

Na quarta parte deste trabalho, listaram-se os resultados e as análises realizadas sobre eles, sintetizando-os nesta parte do trabalho.

O processo de avaliação dissemina-se entre os franqueadores, confundindo-se muitas vezes com controle e monitoramento. Entretanto, um grupo significativo de franqueadores realiza a avaliação de maneira suscetível a críticas. Conforme demonstrado pela análise estatística da hipótese $\mathrm{H}_{(2)}$, simplesmente definir objetivos, definir os dados que serão coletados, levantar esses dados, comparar os objetivos aos resultados encontrados e rever os objetivos, processo denominado neste estudo de avaliação estruturada, já é o suficiente para garantir um processo muito mais consistente de avaliação. Conclui-se, assim, que essas etapas devem estar presentes nos modelos de avaliação desenvolvidos para franquias, de acordo com a literatura sobre modelos prescritivos revisada. Por outro lado, na busca por uma definição de sistema de avaliação de desempenho para organizações, revisão realizada por Franco-Santos et. al. (2007), esses aspectos nem sempre estão presentes.

Apesar das diversas críticas dos autores sobre as avaliações que enfocam prioritariamente nos aspectos financeiros, eles não são o principal objeto de avaliação dos franqueadores, como revelou a análise de freqüências. O enfoque das avaliações é principalmente nos padrões da marca, do produto e das operações. Essa característica pode ser específica do universo particular das franquias, e da suas relações únicas que ocorrem entre franqueador e franqueado. Ressalta-se também que o enfoque em marca e produto é, conforme a literatura, característica de franquias de primeira e segunda geração. Entretanto, a ênfase existente na avaliação da prestação de serviços revela também que muitos franqueadores já estão na terceira geração do franchise.

Há, ainda, por parte dos franqueadores, a preocupação de se avaliar aspectos relacionados a todas as dimensões propostas no trabalho (finanças, operação, cliente, logística, equipe, parcerias e inovação), mas com diferentes intensidades. 
O estudo revelou também que apesar de os franqueadores parecerem preocupados em acompanhar os problemas de atuação dos franqueados, preocupam-se menoss com a avaliação dos próprios problemas, como os aspectos relativos à logística.

Quanto à proposta dos modelos atuais de avaliação, de direcionar a estratégia da organização através do sistema de avaliação, tal procedimento não é claro, mas ocorre em alguns casos, por exemplo na avaliação do treinamento e do atendimento da equipe do franqueado, realizada por muitos franqueadores. O uso de indicadores também é comum.

Sobre o uso de indicadores, ressalta-se que boa parte dos modelos, como o Balanced Scorecard ou o Tableu de board, por exemplo, defendem que parte do sucesso de um sistema de avaliação está nas relações de causa e efeito entre as variáveis analisadas. Essa observação causa surpresa ao pesquisador, que conhece as dificuldades entre supor uma relação de causa e efeito, e provar essa relação. Se é comum a confusão destas com as correlações, mesmo na prática cientifica, o que dizer então nas organizações empresariais, menos atentas ao rigor do método científico?

O estudo revelou também que a desconfiança é comum em algumas redes, sendo o receio de receber informações falsas um aspecto desencorajador de processos de avaliação. No sentido da literatura, destaca-se a importância ressaltada por autores, como Cherto (2006), Mauro (1999), ou Rizzo (2006), da parceria entre franqueador e franqueado, parceria que pode ser reforçada por um processo de avaliação com propósitos claros e resultados partilhados, que como visto, nem sempre é a regra. Ainda nesse sentido, a comunicação entre franqueador e franqueado muitas vezes também é passível de críticas. Outro processo que dificulta a avaliação é o receio pelos franqueados de se fornecer informações, o que reforça a idéia de desconfiança mutua.

De acordo com os resultados, o processo de avaliação nas franquias é pouco dificultado por custos, tempo gasto na avaliação, tamanho da rede ou pelos conflitos que possa gerar. Os custos existem, mas são baixos na relação com os benefícios, de acordo com alguns franqueadores. Esse aspecto é importante, pois questiona algumas discussões sobre teoria de agências, que focam o debate em custos de monitoramento (recursos consumidos para monitorar a atividade dos franqueados). Além disso, a padronização de resultados e das próprias lojas, como conseqüência do processo de avaliação das franquias, é uma de suas 
maiores vantagens, juntamente com integração da rede e resultados financeiros produzidos, na opinião dos franqueadores. Observa-se que o custo de realizar uma avaliação com alguma profundidade não é muito diferente de realizar uma avaliação inconsistente.

Ainda por meio da análise de freqüência, mas sem a realização de prova estatística, nesse caso em função do tamanho da amostra, o estudo discutiu algumas das particularidades de cada setor e as decorrências no processo de avaliação. Percebeu-se, ademais, que é provável que o aumento de competitividade associe-se a um aumento de itens avaliados, ou seja, a uma avaliação mais complexa.

O estudo questiona ainda a divulgação de dados sobre o setor de ensino de maneira unificada, como faz a ABF. Dada a consolidação das escolas de idioma, em comparação com os outros segmentos que atuam nesse setor, deveriam se apresentar esses dados separadamente, para permitir conclusões mais precisas.

No item 4.5, o estudo aprofundou-se sobre questões relativas à tipologia das franquias, comparando estatisticamente as grandes redes com as pequenas, as novas redes com as antigas, as que são remuneradas por royalty com outras diferentemente remuneradas, as que realizam avaliação a partir da definição de objetivos e de seu acompanhamento com as que não o fazem. Foi possível também chegar a diferentes conclusões, como:

- há diferenças entre uma avaliação realizada por franqueadores que cobram royalty em comparação com os que não cobram; o primeiro grupo determina mais metas e objetivos, e verifica com maior frequiência se são atingidos, premiando os franqueados que atingem as metas, aumentando aparentemente o foco nas vendas do franqueado;

- os franqueadores não remunerados por royalty, recebendo principalmente por taxa fixa, têm uma preocupação maior com o volume de produtos vendidos aos franqueados e com a logística, o que sinaliza uma operação mais próxima das franquias de marca e produto;

- o grupo de franqueadores que define objetivos para suas lojas franqueadas, e acompanha se tais objetivos são atingidos, apresenta uma avaliação mais freqüente em 28 dos 47 itens propostos para avaliação. Nesse sentido, conclui-se que os franqueadores do primeiro grupo realizam uma avaliação mais consistente do que os franqueadores que não o fazem, confirmando a segunda hipótese proposta no estudo. Esse grupo associa-se também às maiores redes de franquias; 
- na maior parte do processo de avaliação, o tamanho da rede de franquias, não parece influir na avaliação. Entretanto, a avaliação das operações e dos aspectos ligados à marca (manutenção de maquinas, condições de fachada, condições de higiene, consumo de energia) estão mais fortemente avaliados pelas redes com maior número de lojas franqueadas. Também a participação da rede no grupo de franquias é mais avaliada pelas grandes redes. Finalmente, o grupo das maiores redes em número de lojas franqueadas apresenta-se associado ao grupo das redes que definem objetivos e acompanham sua execução;

- a idade de operação no sistema de franquias pouco explica sobre o processo de avaliação. Há apenas uma maior desconfiança (ou talvez profissionalismo) dos mais antigos. Entretanto, a idade da rede associa-se ao tamanho da rede;

- a existência de um processo consistente de avaliação nas franquias não se associa a um maior crescimento da rede, ao contrário do considerado pela teoria de avaliação;

Espera-se, assim, que o objetivo de descrever o sistema de avaliação nas franquias tenha sido atingido. As tabelas 30 e 31 resumem as conclusões estatísticas encontradas. 
Tabela 30 - Resultados das hipóteses de 1 até 4

\begin{tabular}{|c|c|c|c|}
\hline Núm. & $\begin{array}{l}\text { Hipóteses formuladas } \\
\text { complexas } \mathbf{H}(\mathbf{1})\end{array}$ & $\begin{array}{l}\text { rejeição } \\
\text { de } H(0)\end{array}$ & Observações \\
\hline $\begin{array}{l}\text { H1 } \\
\text { p.109 }\end{array}$ & $\begin{array}{l}\text { Os } \\
\text { remunerados por royueadores } \\
\text { tendem a exercer avaliações } \\
\text { consistentes e periódicas em } \\
\text { suas franquias, mais do que os } \\
\text { franqueadores que recebem } \\
\text { por taxa fixa. }\end{array}$ & Não & $\begin{array}{l}\text { A maior parte dos resultados estatísticos } \\
\text { mostrou diferenças nos processos, porém } \\
\text { no sentido contrário ao proposto. } \\
\text { A remuneração por royalty relaciona-se } \\
\text { apenas ao uso de premiação, definição de } \\
\text { mais objetivos e verificação mais } \\
\text { freqüiente da consecução desses. } \\
\text { A remuneração por taxa fixa associa-se a } \\
\text { uma avaliação mais freqüente de três itens } \\
\text { relativos a produtos. }\end{array}$ \\
\hline $\begin{array}{l}\mathrm{H} 2 \\
\text { p. } 114\end{array}$ & $\begin{array}{l}\text { Os franqueadores que definem } \\
\text { objetivos para suas lojas } \\
\text { franqueadas e acompanham a } \\
\text { realização desses objetivos } \\
\text { tendem a ter uma estrutura de } \\
\text { avaliação mais consistente } \\
\text { (maior), do que aqueles que } \\
\text { não o fazem. }\end{array}$ & Sim & $\begin{array}{l}\text { Encontraram-se diversas associações para } \\
\text { a comprovação da hipótese. A } \\
\text { preocupação de definir objetivos, coletar } \\
\text { dados, verificar se os objetivos foram } \\
\text { atingidos e revê-los, por parte dos } \\
\text { franqueadores, associa-se com seis outras } \\
\text { etapas propostas, e também com } 20 \text { dos } \\
\text { itens propostos, e com } 6 \text { dos } 9 \text { módulos. } \\
\text { Dito de outra forma, franqueadores com } \\
\text { essa preocupação, apresentam uma } \\
\text { avaliação muito mais elaborada do que os } \\
\text { outros. }\end{array}$ \\
\hline $\begin{array}{l}\text { H3 } \\
\text { p.129 }\end{array}$ & $\begin{array}{l}\text { Maiores redes de franquias } \\
\text { apresentam um sistema de } \\
\text { avaliação mais consistente. }\end{array}$ & Sim & $\begin{array}{l}\text { De forma geral, é possível afirmar que as } \\
\text { franquias maiores têm uma avaliação mais } \\
\text { freqüente em sete itens e três etapas. A } \\
\text { uma preocupação maior principalmente } \\
\text { com a marca, e com itens que reflitam } \\
\text { sobre a imagem da rede. }\end{array}$ \\
\hline $\begin{array}{l}\text { H4 } \\
\text { p.135 }\end{array}$ & $\begin{array}{l}\text { As redes que atuam com } \\
\text { franquias, há mais tempo, têm } \\
\text { avaliação diferente daquelas } \\
\text { de atuação mais recente. }\end{array}$ & Sim & $\begin{array}{l}\text { Apenas para o item relativo à avaliação de } \\
\text { ações legais envolvendo os franqueados. } \\
\text { Para todas as outras variáveis propostas } \\
\text { (etapas, itens e módulos). }\end{array}$ \\
\hline
\end{tabular}


Tabela 31 - Resultados das hipóteses de 1 até 4

\begin{tabular}{|c|c|c|c|}
\hline Núm. & Hipóteses formuladas simples H(1) & $\begin{array}{l}\mathrm{H}(0) \\
\text { rejeitada }\end{array}$ & Observação \\
\hline $\begin{array}{l}\text { H5 } \\
\text { p.138 }\end{array}$ & $\begin{array}{l}\text { Há dependência entre o tipo de pagamento } \\
\text { realizado pelo franqueador e o tamanho da } \\
\text { rede. }\end{array}$ & Não & \\
\hline $\begin{array}{l}\text { H6 } \\
\text { p.138 }\end{array}$ & $\begin{array}{l}\text { Há dependência entre o tipo de pagamento } \\
\text { realizado pelo franqueador e o fato do } \\
\text { franqueador apresentar ou não as etapas que } \\
\text { compõem o índice "define e acompanha } \\
\text { objetivos." }\end{array}$ & Não & \\
\hline $\begin{array}{l}\text { H7 } \\
\text { p.139 }\end{array}$ & $\begin{array}{l}\text { Há associação entre o tamanho da rede e o } \\
\text { fato de o franqueador apresentar ou não as } \\
\text { etapas relacionadas a uma avaliação } \\
\text { estruturada em objetivos. }\end{array}$ & Sim & $\begin{array}{l}\text { Em redes maiores, o } \\
\text { processo de avaliação se } \\
\text { aproxima mais das } \\
\text { prescriçõos dos modelos, e } \\
\text { tem maior consistência. }\end{array}$ \\
\hline $\begin{array}{l}\text { H8 } \\
\text { p. } 140\end{array}$ & $\begin{array}{l}\text { Há associação entre o tamanho da rede e a } \\
\text { idade da rede. }\end{array}$ & Sim & $\begin{array}{l}\text { Redes mais antigas são } \\
\text { freqüentemente maiores } \\
\text { que as mais novas. }\end{array}$ \\
\hline $\begin{array}{l}\text { H9 } \\
\text { p. } 141\end{array}$ & $\begin{array}{l}\text { Há associação entre o tamanho da rede e o } \\
\text { fato de o franqueador apresentar ou não as } \\
\text { etapas relacionadas a uma avaliação } \\
\text { estruturada em objetivos. }\end{array}$ & Não & \\
\hline $\begin{array}{l}\text { H10 } \\
\text { p. } 142\end{array}$ & $\begin{array}{l}\text { Há maior taxa de crescimento da rede de } \\
\text { franquias naquelas que definem, revêem e } \\
\text { acompanham a execução de objetivos. }\end{array}$ & Não & $\begin{array}{l}\text { Provavelmente o processo } \\
\text { de avaliação tem pequeno } \\
\text { impacto sobre o } \\
\text { crescimento da rede, em } \\
\text { comparação com todas as } \\
\text { possíveis influências. }\end{array}$ \\
\hline
\end{tabular}

\subsection{Limitacões do estudo.}

O estudo apresenta limitações relativas à generalização das conclusões, pois não se utilizou uma amostra probabilística. Quase a totalidade da amostra afirma que aplica a avaliação de desempenho. Sabe-se, porém, que essa não é a realidade absoluta do mercado, dada a quantidade de pequenas e novas redes existentes. Exemplificando, já no pré-teste, a franquia do ramo de alimentação selecionada não realizava avaliação nas lojas franqueadas (Vivenda do Camarão) ${ }^{46}$, avaliando apenas as lojas próprias; possivelmente, ocorreu um viés de não

\footnotetext{
${ }^{46}$ Deve-se observar que a Vivenda do Camarão é uma franquia não remunerada por royalty, o que pode se correlacionar com uma menor preocupação com o desempenho das unidades. Na amostra deste trabalho, $74 \%$ das franquias utilizavam royalty, enquanto os dados de mercado apontam que $68 \%$ das franquias operam cobrando royalty (RIZZO, 2008, p.29).
} 
resposta na pesquisa. Provavelmente, as franquias que não realizam a avaliação optaram por não responder ao questionário.

Uma explicação alternativa é os respondentes considerarem qualquer processo de verificação de resultados como um processo de avaliação. Reforça essa teoria a exigência pela Lei de franquias da prestação de contas e da exibição de alguns resultados, relativos ao desempenho da rede, ao futuro franqueado (BRASIL, 2007). Por outro lado, há certamente uma amostra representativa das franquias que realizam avaliação.

Os dados encontrados são um provável indicativo das práticas do mercado, mas deve-se atentar aos procedimentos estatísticos realizados para cada parte do estudo. Exemplificando, as afirmações realizadas com relação a setores são, em sua maioria, decorrentes da contagem de freqüência, com um número baixo de respondentes, o que permite apenas reflexão e descrição, mas limita as conclusões.

Nas provas estatísticas, utilizou-se apenas o nível de significância de 0,05. Caso se adote um outro nível, possivelmente se encontre um maior número de associações entre as variáveis.

\section{3 $\underline{\text { Sugestões para estudos futuros }}$}

Ao longo do estudo, elaboraram-se algumas sugestões de trabalhos acadêmicos futuros, retomadas e acrescidas de outras idéias:

- descrever as franquias sociais, já que não se encontraram estudos durante a revisão, apesar de se indicarem na relação da $\mathrm{ABF}$;

- aprofundar o estudo das relações e conflitos entre franqueadores e franqueados;

- realizar estudo similar a este nas redes de varejo que não operam no sistema de franquias, a fim de verificar como os sistemas de avaliação se diferem;

- verificar se os sistemas tornam-se mais complexos à medida que sobe a taxa de royalty, aproveitando os dados já obtidos neste estudo;

- conhecer a atuação social das redes de franquias e as diferenças que parecem existir entre essas atuações quanto ao tamanho da rede;

- verificar se os franqueadores mais novos atuam de maneira mais acessível com os franqueados, por outro lado, menos profissional, como se pode imaginar a partir dos dados obtidos; 
- verificar, estatisticamente, como indica esse estudo, se há uma maior intensidade de avaliação em mercados de intensa concorrência;

- desenvolver um modelo para avaliação de desempenho de franquias;

- desenvolver estudos similares a este, em realidades diferentes, como outros países;

- verificar, em alguns anos, se as franquias participantes deste estudo que apresentavam um sistema de avaliação mais consistente têm uma taxa de mortalidade menor do que as outras;

- realizar estudo similar a este, mudando o enfoque para a avaliação que os franqueadores realizam no próprio desempenho, e não no dos franqueados;

- realizar pesquisa com os franqueados, com base nas conclusões deste estudo, a fim de se verificar quais os pontos principais de concordância e divergência dos achados sobre os franqueadores;

- realizar pesquisa similar em um único setor, preferencialmente algum dos mais consolidados, como o de alimentação, a fim de buscar maiores informações e detalhes sobre as avaliações nos setores.

- uma última sugestão: verificar se os índices de crescimento das franquias comportar-se-ão, em períodos futuros, de alguma forma, vinculados aos resultados obtidos nesta pesquisa. 


\section{REFERÊNCIAS BIBLIOGRÁFICAS}

AGRAWAL D; LAL R. Contractual Arrangements in Franchising: An Empirical Investigation. Journal of Marketing Research, V. 32, N.2, May, p. 213-22, 1995

ALON, Ilan. The use of franchise by US-Based Retailers. Journal of Small Business Management 2001 V.39 N.2 p.111-122

AMBLER et. al. Relating Brand and Customer Perspectives on Marketing Management. Journal of Service Research, V.5, N.1, p.13-25, August 2002

AMPUERO, M.; GORANSSON, J.; SCOTT, J. Solving the measurement puzzle: how EVA and the balanced scorecard fit together, Perspectives on Business Innovation, New York: Ernst \& Young Center for Business Innovation, Capgemini, N.2

ANDRADE, M. M. T. A Inovação em uma Rede de Franchising - Estudo de caso Yázigi. Dissertação de Mestrado, São Paulo: USP Faculdade de Economia e Administração, 1993. 198p.

ASSOCIAÇÃO BRASILEIRA DE FRANCHISING - ABF Guia oficial de Franquias 2004 São Paulo: Editora Empreendedor Ano 6 n.6 2004.

Franquias - Guia oficial 2005. São Paulo: Editora Empreendedor Ano 7 n.7 2005.

Guia oficial de Franquias 2006. São Paulo: Ed. Empreendedor Ano 8 n.8 2006

.Censo do Franchising 2000. São Paulo <disponível em: http://www.portaldofranchising.com.br/area.asp?A040_cod_area=11\&A041_> Acesso em 10 de outubro de 2007.

.Guia de Franquias on-line 2007. São Paulo <Disponível em: http://www.portaldofranchising.com.br/area.asp?A040_cod_area=80 $>$ Acesso em 10 de maio de 2008.

2007

.Franquia e Oportunidades. São Paulo: Editora Lamônica Ano 3 n.13 junho/julho

Guia oficial de Franquias 2008. São Paulo: Ed. Lamônica Ano 10 n.10 2008

BAKER R. B.; BESSIRE D. C. The French Tableau de bord and the American Balanced Scorecard: a critical analysis Critical Perspectives on Accounting No16 p.645-664, 2005.

BARSKY N. P.; BREMSER W. G. Performance Measurement, Budgeting and Strategic Implementation in the Multinational Enterprise. Managerial Finance V.25 N.2, P.3-15, 1999.

BOURGUIGNON A.; MALLERET V; NØRREKLIT H. The American balanced scorecard versus the French tableau de bord: the ideological dimension Management Accounting Research Nº15 p.107-134, 2004.

BEDÊ, M. A. (coordenador) Sobrevivência e Mortalidade das Empresas Paulistas de 1 a 5 Anos. São Paulo: SEBRAE 2005.

BEHN, R. D. Why Measure Performance? Different Purposes Require Different Measures Public Administration Review .Washington: Sep/Oct, V. 63, N. 52003.

BERNSTEIN, PETER L. Desafio dos deuses: a fascinante história do risco Rio de Janeiro: Elsevier, $13^{\mathrm{a}}$ ed. 1997. 
BHATTACHARYYA; LAFONTAINE, Double-Sided Moral Hazard and the Nature of Share Contracts The RAND Journal of Economics, V. 26, N.4, p. 761-781,Winter, 1995

BIRD, S. M. Performance indicators: good, bad, and ugly. Journal of the Royal Statistical Society, Series A, V.168, p.1-27, 2005

BONTIS, N. Assessing Knowledge assets: a review of the models used to measure intellectual capital International Journal of Management Reviews Oxford: Blackwell Publishers, Mar. V.3 p.41-60 2001.

BOURNE; MILLS; WILCOX; NEELY; PLATTS. Designing, implementing and updating performance measurement systems - In. International Journal of Operations \&

Production Management,V.20, N.7, p.754-71, 2000

BRASIL. Congresso. Senado. Lei 8955 de 15/12/1994 - Lei Ordinária. Brasília, DF.

Disponível em: <http://www6.senado.gov.br/legislacao/ListaPublicacoes.action?id=140398>

Acesso em: 12 de setembro de 2007.

BUENO, F. R. I. Sistemas de medição de desempenho para a cadeia de suprimentos: um estudo de caso no setor de lácteos. Dissertação de Mestrado, São Paulo: USP Faculdade de Economia e Administração, 2004. 126p.

COASE, R. The Nature of the firm. 1937.

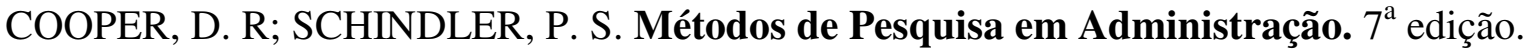

Porto Alegre: Bookman, 2003.

CORRÊA, HAMILTON L. O "Estado da Arte" da Avaliação de Empresas Estatais. Tese de Doutorado, São Paulo: USP Faculdade de Economia e Administração, 1986.

CORRÊA H. L.; HOURNEAUX F. J Uma Análise Crítica dos Métodos de Avaliação de Desempenho Global In: ENCONTRO LUSO BRASILEIRO DE ESTRATÉGIAS PARA O DESENVOLVIMENTO SUSTENTÀVEL DAS ORGANIZAÇÕES - SLADE BRASIL 2006. Anais eletrônicos... Balneário Camburiu: UNIVALLE, 2006.

CHERTO, M. et al. Franchising: uma estratégia para expansão dos negócios. São Paulo: Premier Máxima, 2006.

CHERTO, M. R.; RIZZO, M. Franchising: como comprar sua franquia passo a passo. São Paulo: Makron, McGraw-Hill, 1991.

CHIOU; HSIEH; YANG, The effect of franchisor's Communication service assistance, and competitive advantage on franchisees' intention to remain in the franchise system Journal of small business management V.42 N.1 p.19-36 2004

CHANDLER A. The Visible Hand: The Managerial Revolution in American Business Belknap Press, 1993.

COMBS J. G.; KETCHEN D. J. J. Why do firms use franchising as an entrepreneurial strategy?: A meta-analysis Journal of Management. Tallahassee. V.29, N.3, 2003.

CRETELLA J. NETO Manual Jurídico do Franchising. São Paulo, Atlas, 2003.

CUNHA, J. A. C.; CORRÊA, H. L.; CALEGARI, F. L. O balanced scorecard e a avaliação de inovações: as problemáticas dos paradoxos de inovação e de produtividade. In: Seminários Em Administração - SEMEAD, 10. 2007, São Paulo. Globalização e internacionalização de empresas. São Paulo: EAD/FEA/USP, 2007. 1 CD-ROM. 
DAHLSTEN F.; STYHRE A.; WILLIANDER M. The unintended consequences of management by objectives: the volume growth target at Volvo Cars Leadership \& Organization Development Journal V.26 N.7, 2005 pp. 529-541

DINESH D.; PALMER E. Management by objectives and the Balanced Scorecard: will Rome fall again? Management Decision V.36 N.6, 1998 p.363-369

DEMING, W. E. Out of the Crises. MIT Center for Advanced Engineering Studies. Cambridge, Massachusetts. 110-112, 276-296.

DRICKHAMER, D. Next generation performance measurement. Industry Week, Jul 2002, V.256, N.6, p.14

DRUCKER Peter F. A pratica da administração de empresas. São Paulo: Ed. Pioneira, 1981, $381 \mathrm{p}$.

EDVINSSON, LEIF. Developing intellectual capital at Skandia. Long Range Planning, V.30 N.3, p.266-373, 1997.

EPSTEIN M. J.; MANZONI J. The balanced scorecard and tableau de bord: Translating strategy into action Management Accounting;V.79, N.2. Aug 1997

FOSTER D. L. O livro completo do Franchising. Rio de Janeiro: Infobook, 1995.

FRANCO-SANTOS, M.; MARR, B.; MARTINEZ, B.; GRAY, D.; ADAMS, C.; MICHELI, P.; BOURNE, M.; KENNERLEY, M.; MASON, S. \& NEELY, A. Towards a Definition of a Business Performance Measurement System. In: International Journal of Operations \& Production Management Vol. 27 No. 8, pp. 784-801, 2007

FREITAS H.; OLIVEIRA M.; SACCOL A. Z.; MOSCAROLA J. O método de pesquisa survey. Revista de Administração. São Paulo V.35 N.3 Julho/setembro 2000, p.105-112.

GIANETTI, EDUARDO. Felicidade São Paulo: Cia. das Letras, 2002.

GIL, A. C. Como elaborar projetos de pesquisa. 4 ed. São Paulo:Atlas, 2002.

GIGLIONI G. B.; BEDEIAN A. G. A Conspectus of Management Control Theory: 19001972. The Academy of Management Journal, V.17, N.2 Jun1974, p. 292-305

GOULD, STEPHEN J. A falsa medida do homem. São Paulo: Martins Fontes, 1999.

GUMBUS A.; LUSSIER R. N. Entrepreneurs Use a Balanced Scorecard to Translate Strategy into Performance Measures Journal of Small Business Management 2006 44(3), pp. 407425

HALACHMI, ARIE. Performance measurement is only one way of managing performance International Journal of Productivity and Performance Management V.54 N.7 2005. pp. $502-516$

HAMMER, MICHEL Os sete pecados capitais da medição do desempenho. HSM Management. Barueri/SP HSM Nº.64, Ano11, V.5, Setembro-Outubro 2007 p.43-50

HARVEY, DAVID. A Condição Pós-Moderna 6ed. São Paulo: Loyola, 1996.

HOURNEAUX, F. J. Avaliação de desempenho organizacional: estudo de casos de empresas do setor químico. Dissertação de Mestrado, São Paulo: Universidade de São Paulo, 2005.

HOURNEAUX F. J; MAXIMIANO A. C. A.; CORRÊA H. L.; Sistemas de Mensuração e Avaliação de Desempenho Organizacional: Estudo de Casos no Setor Químico no Brasil In: 
$3^{\circ}$ Encontro Nacional da Associação Nacional de Programas de Pós-graduação em Administração de Empresas - $30^{\circ}$ ENANPAD 2006. Anais eletrônicos... Salvador, 2006.

HOURNEAUX F. Jr.; CUNHA, N. C. V.; CORRÊA, H. L. A importância da inovação na utilização do balanced scorecard nas organizações: um estudo de caso. In: ASAMBLEA ANUAL DEL CONSEJO LATINOAMERICANO DE ESCUELAS DE ADMINISTRACIÓN - CLADEA, 39. 2004, Puerto Plata, República Dominicana. Gestión y competencias frente al desafio de la integración de los mercados. Puerto Plata: CLADEA/Pontificia Universidad Católica Madre y Maestra, 2004. 1 CD-ROM.

HOURNEAUX F. Jr ; CORRÊA, H. L. A influência do fator humano na mensuração e avaliação do desempenho organizacional: estudo de casos de empresas do setor químico. In: Encontro da Associação Nacional de Programas de Pós-Graduação em Administração ENANPAD, 31., 2007, Rio de Janeiro. Anais... Rio de Janeiro: ANPAD, 2007. 1 CD ROM.

IKEDA, J. et. al. Benchmarking de franquias da rede Dunkin'donuts, através do Data Envelopment Analysis. In: CONGRESSO INTERNACIONAL DE ENGENHARIA INDUSTRIAL. Niterói, 1998. Anais. Niterói : UFF/TEP, 1998. .

INSTITUTO BRASILEIRO DE CULTURA Anuário de Franquias. São Paulo: On Line Editora. Ano 3 n.3 2008

INSTITUTO FRANCHISING Guia completo de franquias 2007. São Paulo: Editora Empreendedor n. 1, 2007.

INTERNATIONAL FRANCHISE ASSOCIATION The Economic Impact of Franchised Businesses - Executive Summary and Highlights V.2 Feb. 2005. Disponível em < http://franchise.org/uploadedFiles/Franchisors/Other_Content/economic_impact_documents/ EconomicOutput.pdf >Acesso em: 5/08/2008.

IOCHPE. São Paulo. Disponível em: < http://www.formare.org.br/> Acesso em: 17/08/2007.

JENSEN, M. C.; MECKLING W. H. Theory of the Firm: Managerial Behavior, Agency Costs and Ownership Structure Journal of Financial Economics, Universidade de Rochester, V.3, N.4, pp. 305-360. October, 1976.

JOHNSON, H. Thomas; KAPLAN, Robert S. Contabilidade gerencial: a restauração da relevância da contabilidade nas empresas. Tradução: Ivo Korytowski. Rio de Janeiro: Campus, 1993.

KAPLAN, R. S.; NORTON, D. P. The Strategy Focused Organization: how balance scorecard companies thrive in the new business environment. Boston: Harvard Scholl Press, 2001.

A Estratégia em Ação: balanced scorecard. Rio de Janeiro: Ed. Campus, 1997.

Response to S. Voelpel et al., The tyranny of the Balanced Scorecard in the innovation economy, In. Journal of Intellectual Capital, V.7 N.1, 2006, pp.43-60

KENNERLEY M.; NELLY A. Measuring performance in a changing business enviroment In. International Journal of Operations \& Production Management V.23 N.2, p.213-229, 2003

KENNY GHARAM, Balanced Scorecard - Why it isn't working? Neo Zealand Management March, 2003.

Disponível em:<http://www.archivesearch.co.nz/default.aspx?webid=MGT\&articleid=9481> 
Acesso em 15 de Outubro de 2006

KOTLER, PHILIP Administração de Marketing: Analise Planejamento Implementação e Controle. $5^{\text {a }}$ ed. São Paulo: Atlas, 1998.

LAFONTAINE, F. Agency Theory and Franchising: Some Empirical Results. The RAND Journal of Economics. Santa Monica: Rand Corporation V.23, N.2 Summer 1992 p.263-283.

LAWSON R.; STRATTON W.; HATCH T.; Scorecards and dashboards - partners in performance CMA Management. V.80, N.8; Dec 2006/Jan 2007

LEBAS M. Managerial Accounting in France: Overview of Past Tradition and Current Practice The European Accounting Review, Vol. 3, No3, pp. 471-487. 1994

MARQUES, DALTON S. P. Internacionalização de franquias: um mapeamento sobre a presença de redes brasileiras no exterior. Dissertação de Mestrado, São Paulo: Universidade de São Paulo, FEARP, 2006.

MARTINDELL, JACKSON. The Scientific Appraisal of Management. NY: Harper \& Brothers, $1^{\text {a }}$ ed. 1950

MATTAR, Fauze Nagib. Pesquisa de Marketing Volume 1. $3^{\text {a }}$ edição. São Paulo: Editora Atlas, 1996.

MATHEWSON F. G.; WINTER R. A., The Economics of Franchise Contracts The Journal of Law and Economics The University of Chicago Press.V.28, N.3, p. 503 October 1985

MAURO, P. C. Guia do franqueador: como fazer sua empresa crescer com o franchising. $3^{\text {a }}$ ed. São Paulo: Nobel, 1999.

MAXIMIANO, A. C. A. . Teoria Geral da Administração: da Revolução Urbana à Revolução Digital. $5^{\text {a }}$ ed. São Paulo: Editora Atlas, 2005. v. 1.503 p.

,Teoria Geral da Administração: da Revolução Urbana à Revolução Digital. $3^{\text {a }}$ ed. São Paulo: Editora Atlas, 2002. v. 1. 521 p.

Introdução a Administração São Paulo: Ed. Atlas, 2004. p.434.

MERLO, EDGAR M. O desempenho do setor de franquias no Brasil: um estudo exploratório dos principais condicionantes de performance. Tese de Doutorado, São Paulo: Universidade de São Paulo, FEAUSP, 2000.

MERRILEES B.; FRAZER L. Entrepreneurial franchisees have hidden superior marketing systems In. Qualitative Market Research. Brisbane: Griffith University, V.9 N.1, p.73-85, 2006.

MICHAEL S.C. First mover advantage through franchising. Journal of Business Venturing [Illinois]: Universidade de Illinois V.18 2003 p.61-80

MINTZBERG H.; AHLSTRAND B.; LAMPEL J. O safári da estratégia: um roteiro pela selva do planejamento. Porto Alegre: Bookman, 2000.

MINTZBERG, H.; LAMPEL J.; QUINN J. B. GHOSHAL S.. O processo da estratégia: conceitos, contextos e casos selecionados. Porto Alegre: Bookman, 2006

MONSMA, Karl. Repensando a Escolha Racional e a Teoria da Agência: fazendeiros de gado e capatazes no século XIX Revista Brasileira das Ciências Sociais V.15 n.43 junho de 2000.

MORETTI L. The Performance Connection Organization Development Journal Summer 2007, V.25, N.2 
MOURITSEN J.; LARSEN H.T.; BUKH P.N. Valuing the future: intellectual capital supplements at Skandia. Accounting, Auditing \& Accountability Journal. V.14 N.4 p.399422, 2001.

NELLY, ANDY. The Evolution of performance measurament research Journal of Operations \& Production Management. Cambridge (UK):University of Cambridge, V.25, N.12, 2005, p.1264-1277.

NEELY A.; GREGORY M.; PLATTS K. Performance measurement system design - A literature review and research agenda International Journal of Operations \& Production Management. Cambridge (UK):University of Cambridge, V.25, N.12, 2005, p.1228-1263.

PARANJAPE B.; ROSSITER M.; PANTANO V. Insights for the Balanced Scorecard Performance Measurement Systems: Success Failures and Future - a review Measuring Business Excellence [Conventry (U. K)]. V.10, N.3, 2006 p 4 -14.

RASCÃO, JOSÈ Sistemas de Informação para as Organizações - A informação Chave para a Tomada de Decisão. $2^{\text {a }}$ ed. Lisboa: Edições Silabo, 2004.

REA L; PARKER R. Metodologia de Pesquisa do Planejamento a Execução, São Paulo, Ed. Thompson Pioneira, 2000.

RISNER Mary E. Successful fast-food franchising in Brazil and the role of culture: four cases Dissertação de Mestrado, Flórida: Universidade da Flórida, 2001.

RIZZO, M.; CHERTO, M. Franchising na Prática. São Paulo: Makron Books, 1994.

RIZZO, M. Franchising o negócio do século. Itu(SP): Ottoni Ed : Rizzo Franchise, 2006.

SANDRONI, Paulo. Novíssimo Dicionário de Economia. São Paulo: Ed. Best Seller. 1999.

SCHUMPETER, J. A. A Teoria do Desenvolvimento Econômico : uma investigação sobre lucros, capital, crédito, juro e o ciclo econômico. São Paulo: Abril Cultural, 1982.

SHANE, S.; FOO MAW-DER New firm survival: Institutional explanations for new franchisor mortality. Management Science. Feb 1999. V.45, N.2 pg.142

SILVA, REINALDO O. Teorias da Administração. São Paulo: Pioneira Thomson Learning, 2004.

SILVA, ROSIMEIRE. de CARVALHO. Controle Organizacional, Cultura e Liderança: Evolução, Transformações e Perspectivas In: Encontro De Estudos Organizacionais, 2., 2002, Recife. Anais... Recife: Observatório da Realidade Organizacional: PROPAD/UFPE : ANPAD, 2002. 1 CD.

SILVA, VIVIAN L. dos S. O papel das franquias de alimentos na coordenação e gerenciamento de cadeias agroindustriais. Dissertação de Mestrado, São Carlos: UFSCar, 1999. 197p.

SIMON, H. A.; Models of Bounded Rationality, v. 3 Empirically grounded economic reason Massachusetts: Massachusetts Institute of Technology, 1997

SCRIVEN M. An overview of evaluation theories V.1, N.2 Dec 2001

SELLTIZ, Claire. Métodos de Pesquisa nas Relações Sociais. São Paulo: Editora Herder, 1974.

SLACK N. et al. Administração da produção. São Paulo: Atlas, 1996.

SPINELLI, S.;BIRLEY S. An Empirical Evaluation of Conflict in the Franchise System. British Journal of Management, V.9, p.301-325 1998 
TANNENBAUM, A.S. Control in organizations. New York: Mcgraw Hill. 1968.

TOLEDO,G.; OVALLE I. Estatística Básica São Paulo: Atlas, 1985.

VARIAN, HAL R., Microeconomia: Princípios Básicos, 6º ed., Editora Campus, 2003.

VOEPEL, VOELPEL S. C.; LEIBOLD M.; ECKHOFF R. A. The tyranny of the Balanced Scorecard in the innovation economy. Journal of Intellectual Capital V.7, N.1, 2006 p. 4360

WELSH, D. H. B.; ALON I.; FALBE C. M. An Examination of International Retail Franchising in Emerging Markets. Journal of Small Business Management. v.44 2006. p. 130-149

WRIGHT, ROBERT. Não-Zero: a lógica do destino humano. Rio de Janeiro: Campus, 2000 .

ZIMMERMANN, K. Using the Balanced Scorecard for inter-organizational performance in supply chains - a case study. In: SEURING S.; GOLDBACH M. Cost management in supply chains. Heidelberg: Physica-Verlag. 2002. 


\section{APÊNDICES}

\subsection{Apêndice I - Convite enviado por e-mail.}

Caro Franqueador (nome da empresa franqueadora),

A Faculdade de Contabilidade, Economia e Administração da Universidade de São Paulo (FEAUSP) está realizando um estudo inédito sobre os sistemas de avaliação de desempenho dos franqueadores. Esse trabalho tem como objetivo contribuir para a geração de conhecimento sobre esse importante setor da economia brasileira. Os resultados serão utilizados para elaboração de dissertação de mestrado na FEA-USP, e artigo científico.

Obtivemos a indicação de sua rede de franquias como um possível respondente desse estudo. Posteriormente, será disponibilizado gratuitamente, apenas para os respondentes da pesquisa, um relatório consolidado dos resultados apurados.

O link para a pesquisa é: http://www.feausp.com.br/questionario/franquia/

Desde já, agradecemos a sua colaboração,

Carlos Amorim Lavieri

F.1130634019 


\subsection{Apêndice II - Instrumento de coleta de dados}

O questionário a seguir é a versão final, concebido após o pré-teste e disponibilizado via web, em endereço eletrônico. Convidaram-se os franqueadores através de dois e-mails, e ao acessarem o link, eles visualizavam as páginas a seguir:

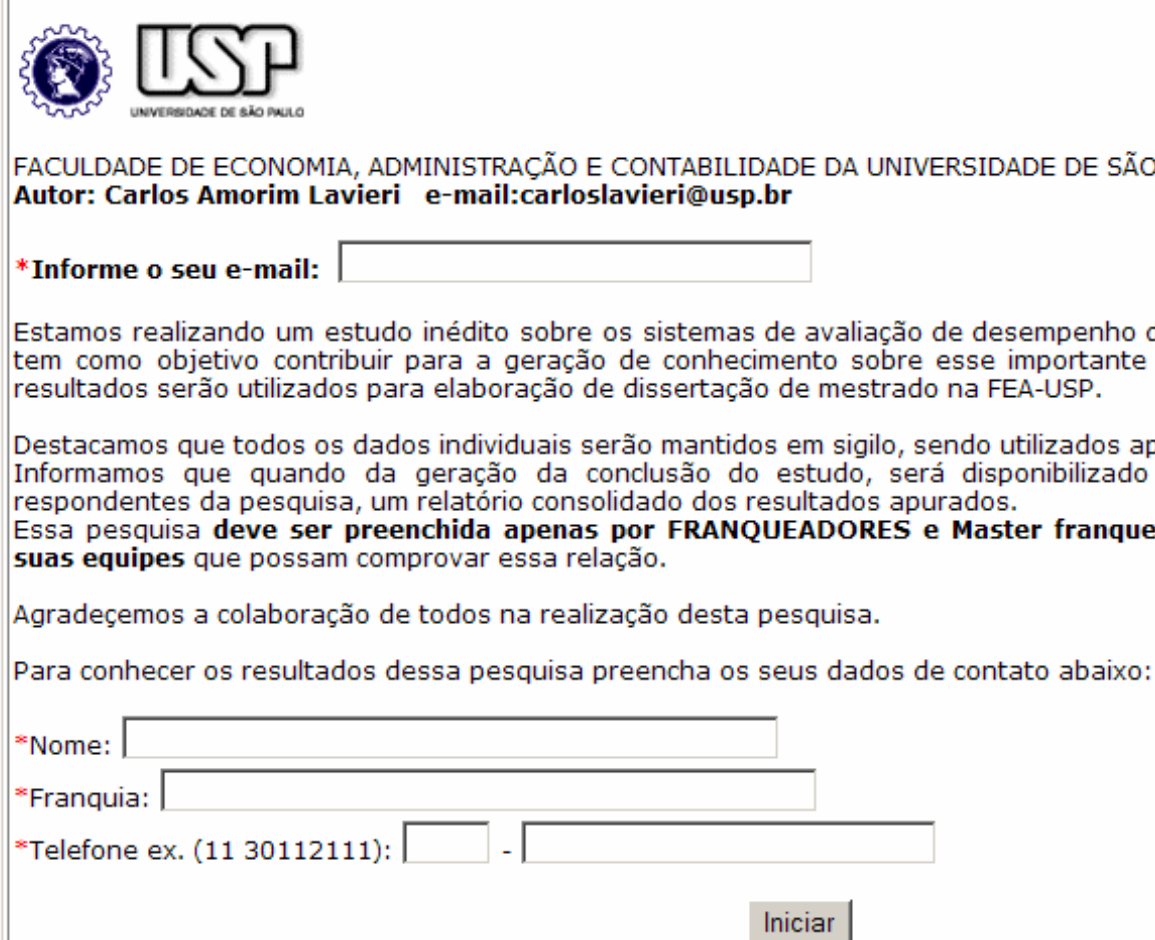
resultados serão utilizados para elaboração de dissertação de mestrado na FEA-USP. respondentes da pesquisa, um relatório consolidado dos resultados apurados. suas equipes que possam comprovar essa relação.

Agradeçemos a colaboração de todos na realização desta pesquisa.

Para conhecer os resultados dessa pesquisa preencha os seus dados de contato abaixo:

Nome:

*Franquia:

Telefone ex. (11 30112111):

Estamos realizando um estudo inédito sobre os sistemas de avaliação de desempenho dos franqueadores. Essa pesquisa tem como objetivo contribuir para a geração de conhecimento sobre esse importante setor da economia brasileira. Os

Destacamos que todos os dados individuais serão mantidos em sigilo, sendo utilizados apenas dados agregados. Informamos que quando da geração da conclusão do estudo, será disponibilizado gratuitamente, apenas para os

Essa pesquisa deve ser preenchida apenas por FRANQUEADORES e Master franqueados nacionais, ou membros de 


\section{Caracterização da Franquia}

* 1 - Qual o setor de atuação?

Escolha

*2. Quantas lojas operam com a sua marca?

*3. Dessas, quantas são lojas franqueadas?

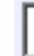

*4. Quando a marca começou a operar através do sistema de franquias? Escolha

*5. Qual era o número total de lojas franqueadas operando com sua marca há 3 anos?

*6. Qual era o número total de lojas franqueadas operando com sua marca há 6 anos?

*7. Qual o investimento total necessário para abrir uma loja padrão?

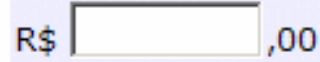

*8 - Em quanto tempo, em média, o franqueado padrão recupera o investimento?

Escolha $\rightarrow$ Anos e 0 Meses

Como o franqueador é remunerado? (marque as colunas)

9. Aluguéis de equipamentos ou ponto comercial.

10. Royalts (porcentagem do faturamento ou do resultado).

11. Taxa fixa independente do faturamento.

12. Na venda de produtos ao franqueado. 


\section{SOBRE O SISTEMA DE AVALIAÇÃO DAS FRANQUIAS}

*13. O franqueador realiza avaliação das LOJAS FRANQUEADAS?

C $\operatorname{sim}$

○ Não

Marque no quadro abaixo as etapas presentes na avaliação da LOJAS FRANQUEADAS:

14.Definição da equipe responsável pela avaliação.

15.Definição dos objetivos a serem atingidos.

16.Definição dos dados a serem coletados

17.Definição das dimensões/módulos a serem estudados. (financeiro, recursos humanos, clientes, etc.)

18.Definição dos pesos e critérios para cada item pesquisado.

19.Construção de indicadores.

20.Levantamento de dados.

21.Integração dos resultados nos módulos ou dimensões.

22. Comparação dos resultados obtidos com esperados e relatório final.

23.Sugestões de mudanças.

24.Punição em função do resultado medido.

25.Premiação em função do resultado medido.

26.Revisão dos objetivos.

27.Revisão do sistema de avaliação.

*28. O franqueador realiza avaliação das LOJAS PRÓPRIAS?

C Sim

C Não

Continua 
*29. Os processos de avaliação das LOJAS PRÓPRIAS e das LOJAS FRANQUEADAS são iguais?

C Sim Não

30. Caso a resposta anterior tenha sido negativa, explique porque eles diferem?

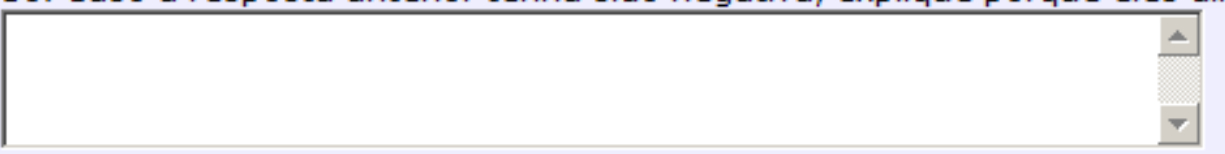

*31. O franqueador avalia as LOJAS FRANQUEADAS de quanto em quanto tempo? Escolha

32. Quais dos aspectos financeiros a seguir são considerados nas avaliações realizadas pelo FRANQUEADOR nas LOJAS FRANQUEADAS? (marque as colunas) - Caso não avalie, pule essa questão.

1. Volume de produtos vendidos pela loja.

Г

2. Volume de produtos vendidos para o franqueado. $\Gamma$

3. Giro de estoque do franqueado.

4. Lucro da loja.

5. Faturamento da loja.

6. Retorno sobre ativos na loja.

7. Custos operacionais da loja.

8. Despesas com impostos da loja.

9. Despesas financeiras da loja.

10. Outros aspectos financeiros.

32. Nas avaliações realizadas pelo FRANQUEADOR nas LOJAS FRANQUEADAS, são avaliados aspectos não financeiros, relativos à marketing ou operação, como os abaixo? (marque as colunas)

11. Manutenção do maquinário / equipamento da loja.

12. Respeito aos padrões da marca.

13. Condições do espaço físico (manutenção)

14. Atualização tecnológica (máquinas, computadores, softwares, etc...) $Г$

15. Condições da fachada / vitrine

16. Consumo de energia / água da loja

17. Outros aspectos de infra-estrutura

18. Condições de Higiene na loja

19. Eficiência dos funcionários da loja

20. Satisfação do cliente daquela loja.

21. Aumento/diminuição da concorrência na região da loja.

22. Fidelização dos clientes da loja (retorno do mesmo cliente)

23. Perfil dos clientes da loja (renda, faixa etária, gênero,...)

24. Atendimento ao cliente na loja (tempo, pós-venda,...)

25. Mudanças relevantes na região (obras urbanas, shoppings,...)

26. Mudanças populacionais na região (perfil, densidade urbana, ...) 
32. Nas avaliações realizadas pelo FRANQUEADOR nas LOJAS FRANQUEADAS, são avaliados aspectos relativos à gestão de pessoal, logística ou inovação, como os abaixo? (marque as colunas)

\section{Satisfação / Motivação da equipe}

28. Treinamento do franqueado / gestor /administrativo

29. Treinamento do pessoal operacional

30. Qualidade do atendimento na loja

31. Identificação da equipe da loja com os atributos da marca

32. Rotatividade dos funcionários

33. Uso dos softwares de gestão

34. Preenchimento dos pedidos (prazo, correção)

35. Estoque (variabilidade de tamanhos, tipos, moda)

36. Perdas de estoque (furtos, validade, acondicionamento)

37. Tempo de entrega dos produtos / insumos na loja

38. Recebimento dos produtos/ insumos na loja

39. Relacionamento do franqueado com os outros fornecedores de insumos.

40. Relacionamento com o franqueador

41. Participação da loja em ações promocionais da rede

42. Participação da loja em ações sociais promovidas pela rede

43. Processos Judiciais de terceiros contra a loja/franqueado

44. Participação do franqueado nos debates dos grupos dos franqueados

45. Avaliação das inovações propostas à loja pelo franqueador

46. Avaliação das inovações criadas pelo franqueado

47. Avaliação das sugestões de mudanças propostas pelo franqueado

Quantos indicadores são construídos a partir dos aspectos apresentados anteriormente (apenas para as lojas FRANQUEADAS)?

\begin{tabular}{|l|c|c|c|c|c|}
\hline & Nenhum & Até 10 & De 11 até 30 & De 30 até 50 & Mais de 50 \\
\hline 33. Para a rede de franquias & $\mathrm{C}$ & $\mathrm{C}$ & $\mathrm{C}$ & $\mathrm{C}$ & $\mathrm{C}$ \\
\hline 34. Para a loja franqueada & $\mathrm{C}$ & $\mathrm{C}$ & $\mathrm{C}$ & $\mathrm{C}$ & $\mathrm{C}$ \\
\hline
\end{tabular}

Continuar 
Finalizando a pesquisa - página 3. (70\% já preenchidos)

Quantos objetivos e metas o franqueador define para:

\begin{tabular}{|l|c|c|c|c|c|}
\hline & Nenhum & Até 10 & De 11 até 20 & De 21 até 40 & Mais de 40 \\
\hline *35. As lojas franqueadas & $C$ & $C$ & $C$ & $C$ & $C$ \\
\hline ×36. As lojas próprias & $C$ & $C$ & $C$ & $C$ & $C$ \\
\hline
\end{tabular}

*37. Os franqueados ou seus representantes participam na fase de definição dos objetivos e metas? Escolha

O franqueador verifica se os objetivos e metas foram atingidos para:

\begin{tabular}{|l|c|c|}
\hline & SIM & NẤ \\
\hline 38. As lojas franqueadas. & $C$ & $C$ \\
\hline 39. As lojas próprias & $C$ & $C$ \\
\hline
\end{tabular}

*40. Quem executa a avaliação do desempenho da loja franqueada? Escolha

*41. O resultado da avaliação é enviado ao franqueado?

Escolha

*41a. As avaliações e seus procedimentos geram conflitos com (ou entre) os franqueados?

C $\operatorname{sim}$

C Não

41b. Caso a resposta anterior tenha sido positiva, se possível dê um exemplo que conheça: 
No quadro abaixo, marque um valor de 1 até 7 , considerando o quanto você acredita que cada fator influencia a realização das avaliações na sua rede. Considere:
1 - "Facilita muito a avaliação"
2 - "Facilita"
5 - "Atrapalha pouco"
3 - "Facilita pouco"
6 - "Atrapalha"
4 - "É neutro com relação a avaliação."
7 - "Atrapalha muito a avaliação."

\begin{tabular}{|l|l|l|l|l|l|l|l|}
\hline \multicolumn{1}{|c|}{ FATOR DA AVALIAÇÃO } & 1 & 2 & 3 & 4 & 5 & 6 & 7 \\
\hline *42. O custo econômico. & $\mathrm{C}$ & $\mathrm{C}$ & $\mathrm{C}$ & $\mathrm{C}$ & $\mathrm{C}$ & $\mathrm{C}$ & $\mathrm{C}$ \\
\hline *43.Os conflitos que a avaliação pode gerar. & $\mathrm{C}$ & $\mathrm{C}$ & $\mathrm{C}$ & $\mathrm{C}$ & $\mathrm{C}$ & $\mathrm{C}$ & $\mathrm{C}$ \\
\hline *44. A opinião/posição da diretoria sobre avaliação. & $\mathrm{C}$ & $\mathrm{C}$ & $\mathrm{C}$ & $\mathrm{C}$ & $\mathrm{C}$ & $\mathrm{C}$ & $\mathrm{C}$ \\
\hline *45. As soluções que a avaliação pode gerar para os franqueados. & $\mathrm{C}$ & $\mathrm{C}$ & $\mathrm{C}$ & $\mathrm{C}$ & $\mathrm{C}$ & $\mathrm{C}$ & $\mathrm{C}$ \\
\hline *46. A padronização dos resultados pelo processo de avaliação. & $\mathrm{C}$ & $\mathrm{C}$ & $\mathrm{C}$ & $\mathrm{C}$ & $\mathrm{C}$ & $\mathrm{C}$ & $\mathrm{C}$ \\
\hline *47. Informações falsas prestadas por alguns dos avaliados. & $\mathrm{C}$ & $\mathrm{C}$ & $\mathrm{C}$ & $\mathrm{C}$ & $\mathrm{C}$ & $\mathrm{C}$ & $\mathrm{C}$ \\
\hline *48. Receio de fornecer informações pelos franqueados. & $\mathrm{C}$ & $\mathrm{C}$ & $\mathrm{C}$ & $\mathrm{C}$ & $\mathrm{C}$ & $\mathrm{C}$ & $\mathrm{C}$ \\
\hline *49. O tamanho da rede. & $\mathrm{C}$ & $\mathrm{C}$ & $\mathrm{C}$ & $\mathrm{C}$ & $\mathrm{C}$ & $\mathrm{C}$ & $\mathrm{C}$ \\
\hline *50. A opinião dos colaboradores e franqueados. & $\mathrm{C}$ & $\mathrm{C}$ & $\mathrm{C}$ & $\mathrm{C}$ & $\mathrm{C}$ & $\mathrm{C}$ & $\mathrm{C}$ \\
\hline *51. O tempo usado para a avaliação. & $\mathrm{C}$ & $\mathrm{C}$ & $\mathrm{C}$ & $\mathrm{C}$ & $\mathrm{C}$ & $\mathrm{C}$ & $\mathrm{C}$ \\
\hline *52. A possibilidade de comparar resultados entre as diversas unidades. & $\mathrm{C}$ & $\mathrm{C}$ & $\mathrm{C}$ & $\mathrm{C}$ & $\mathrm{C}$ & $\mathrm{C}$ & $\mathrm{C}$ \\
\hline *53. O retorno econômico que a avaliação pode produzir. & $\mathrm{C}$ & $\mathrm{C}$ & $\mathrm{C}$ & $\mathrm{C}$ & $\mathrm{C}$ & $\mathrm{C}$ & $\mathrm{C}$ \\
\hline *54. A integração que a avaliação pode produzir. & $\mathrm{C}$ & $\mathrm{C}$ & $\mathrm{C}$ & $\mathrm{C}$ & $\mathrm{C}$ & $\mathrm{C}$ & $\mathrm{C}$ \\
\hline
\end{tabular}

55. Espaço para comentários:

\section{CONCLUIDO}

\section{Campos disponíveis nas questões de múltipla escolha.}

Questão 1 - Qual o setor de atuação:

Assessórios e calçados.

Beleza, saúde e produtos naturais.

Construção.

Educação e treinamento.

Escolas de idiomas.

Hotelaria e turismo.

Alimentação.

Comunicação informática e eletrônicos.

Cosméticos e perfumaria.

Entretenimento.

Livrarias e papelaria.

Fotografias, gráficas e sinalização.

Limpeza e conservação.

Móveis decorações e presentes.

Automotivos.

Serviços, negócios e conveniências.

Vestuário. 
Questão 31 - O franqueador avalia as lojas franqueadas de quanto em quanto tempo:

Nunca, não avaliamos unidades franqueadas.

Não há periodicidade definida.

Diária.

Mensal.

Bimestral.

Trimestral.

Semestral.

Anual.

Bianual.

Maior que uma vez a cada dois anos.

Questão 37 - Os franqueados ou seus representantes participam da fase de definição de objetivos e metas?

Não ocorre a participação.

Apenas para a loja própria do franqueado.

Para todas as lojas franqueadas.

Para toda a rede de lojas.

Questão 40 - Quem executa a avaliação de desempenho da loja franqueada?

Não sei

Apenas o franqueador.

Apenas o franqueado.

$\mathrm{O}$ franqueador e o franqueado.

Um avaliador externo à rede contratado.

$\mathrm{O}$ franqueador, o franqueado, e um avaliador externo.

Questão 41 - O resultado da avaliação é enviado ao franqueado?

Não é enviado nenhum resultado de avaliação.

Somente o da própria loja.

O da própria loja e uma média das outras lojas.

$\mathrm{O}$ resultado de todas as lojas franqueadas.

$\mathrm{O}$ resultado de todas as lojas próprias.

$\mathrm{O}$ resultado de todas as lojas próprias e franqueadas. 


\section{ANEXOS}

\subsection{Anexo I - Provas estatísticas: Royalty}

As tabelas a seguir apresentam os dados das provas estatísticas sem resultados relevantes.

Tabela 32 - Teste de Kolmogorov-Smirnov para Royalty

\begin{tabular}{l|c|c|c|c}
\hline & \multicolumn{2}{l|}{ Maior diferença } & Kolmogorov- \\
\cline { 3 - 5 } Questão & Absoluta & Positiva & Negativa & $\begin{array}{c}\text { Smirnov } \\
\left(\chi^{2}\right)\end{array}$ \\
\hline $\begin{array}{l}\text { 31. O franqueador avalia as lojas franqueadas de } \\
\text { quanto em quanto tempo? }\end{array}$ & 0,129 & 0,129 & $-0,121$ & 0,742 \\
$\begin{array}{l}\text { 33. Número de indicadores construídos para a } \\
\text { rede de franquias }\end{array}$ & 0,319 & 0,042 & $-0,319$ & 4,122 \\
$\begin{array}{l}\text { 34. Número de indicadores construídos para a } \\
\text { loja franqueada }\end{array}$ & 0,291 & 0,100 & $-0,291$ & 3,260 \\
$\begin{array}{l}\text { 35. Quantos metas/objetivos o franqueador } \\
\text { define para as lojas franqueadas? }\end{array}$ & 0,286 & 0,000 & $-0,286$ & 3,242 \\
\hline
\end{tabular}

Tabela 33 - Freqüências Mann-Whitney para Royalty

\begin{tabular}{|c|c|c|c|c|}
\hline & $\begin{array}{l}\text { 10. Remuneração } \\
\text { por Royalts. }\end{array}$ & $\mathrm{N}$ & $\begin{array}{l}\text { Média de } \\
\text { postos }\end{array}$ & $\begin{array}{l}\text { Soma de } \\
\text { postos }\end{array}$ \\
\hline \multirow[t]{3}{*}{ 2. Quantas lojas operam com a sua marca? } & Não & 15 & 34,67 & 520,00 \\
\hline & Sim & 48 & 31,17 & $1.496,00$ \\
\hline & Total & 63 & & \\
\hline \multirow[t]{3}{*}{ 3. Dessas, quantas são lojas franqueadas? } & Não & 15 & 34,83 & 522,50 \\
\hline & Sim & 48 & 31,11 & $1.493,50$ \\
\hline & Total & 63 & & \\
\hline \multirow{3}{*}{$\begin{array}{l}\text { 7. Qual o investimento total necessário para } \\
\text { abrir uma loja padrão? }\end{array}$} & Não & 15 & 29,33 & 440,00 \\
\hline & Sim & 48 & 32,83 & $1.576,00$ \\
\hline & Total & 63 & & \\
\hline \multirow{3}{*}{$\begin{array}{l}\text { 8. Em quanto tempo, em média, o franqueado } \\
\text { padrão recupera o investimento? (em meses) }\end{array}$} & Não & 15 & 29,17 & 437,50 \\
\hline & Sim & 48 & 32,89 & $1.578,50$ \\
\hline & Total & 63 & & \\
\hline \multirow[t]{4}{*}{ Tempo de franquia } & Não & 15 & 32,23 & 483,50 \\
\hline & Sim & 48 & 31,93 & $1.532,50$ \\
\hline & Total & 63 & & \\
\hline & \multicolumn{2}{|c|}{ Mann-Whitney U } & $\bar{Z}$ & $\begin{array}{c}\text { p (nível } \\
\text { descritivo) }\end{array}$ \\
\hline 2. Quantas lojas operam com a sua marca? & \multicolumn{2}{|l|}{320,000} & $-0,646$ & 0,518 \\
\hline 3. Dessas, quantas são lojas franqueadas? & \multicolumn{2}{|l|}{317,500} & $-0,686$ & 0,493 \\
\hline $\begin{array}{l}\text { 7. Qual o investimento total necessário para abrir uma } \\
\text { loja padrão? }\end{array}$ & \multicolumn{2}{|l|}{320,000} & $-0,646$ & 0,518 \\
\hline $\begin{array}{l}\text { 8. Em quanto tempo, em média, o franqueado padrão } \\
\text { recupera o investimento? (em meses) }\end{array}$ & \multicolumn{2}{|l|}{317,500} & $-0,697$ & 0,486 \\
\hline tempo de franquia & \multicolumn{2}{|l|}{356,500} & $-0,057$ & 0,955 \\
\hline
\end{tabular}




\begin{tabular}{|c|c|c|}
\hline Questão & Prova Estatística & $\begin{array}{c}\text { Nível } \\
\text { descritivo } \\
\text { (p) }\end{array}$ \\
\hline Etapas presentes na avaliacão Definição da equipe responsável & Prova de Fisher & 0,137 \\
\hline $\begin{array}{l}\text { Etapas presentes na avaliação Definição dos objetivos a serem } \\
\text { atingidos. }\end{array}$ & Prova de Fisher & 0,667 \\
\hline Etapas presentes na avaliação Sugestões de mudanças. & Prova de Fisher & 0,622 \\
\hline Etapas presentes na avaliação Punição em funcão do resultado. & Prova de Fisher & 0,716 \\
\hline O franqueador realiza avaliação das lojas próprias? & Prova de Fisher & 1,000 \\
\hline $\begin{array}{l}\text { Considerado na avaliação: Volume de produtos vendidos pela } \\
\text { loja. }\end{array}$ & Prova Qui-Quadrado & 0,200 \\
\hline Considerado na avaliação: Lucro da loja. & Prova Qui-Quadrado & 0,585 \\
\hline Considerado na avaliação do franqueador: Faturamento da loja. & Prova de Fisher & 0,407 \\
\hline Considerado na avaliação: Retorno sobre ativos na loja. & Prova de Fisher & 0,666 \\
\hline Considerado na avaliação: Custos operacionais da loja. & Prova Qui-Quadrado & 0,697 \\
\hline Considerado na avaliação: Condições da fachada / vitrine & Prova de Fisher & 0,407 \\
\hline Considerado na avaliação: Satisfação do cliente daquela loja. & Prova de Fisher & 1,000 \\
\hline $\begin{array}{l}\text { Considerado na avaliação: Aumento/diminuição da concorrência } \\
\text { na região da loja. }\end{array}$ & Prova Qui-Quadrado & 0,814 \\
\hline Considerado na avaliação: Fidelização dos clientes da loja & Prova de Fisher & 1,000 \\
\hline Considerado na avaliação: Perfil dos clientes da loja & Prova Qui-Quadrado & 0,708 \\
\hline Considerado na avaliação: Atendimento ao cliente na loja & Prova de Fisher & 1,000 \\
\hline Considerado na avaliação: Treinamento do franqueado & Prova de Fisher & 1,000 \\
\hline Considerado na avaliação: Rotatividade dos funcionários & Prova Qui-Quadrado & 0,801 \\
\hline Considerado na avaliação: Uso dos softwares de gest & Prova de Fisher & 0,704 \\
\hline $\begin{array}{l}\text { Considerado na avaliação: Relacionamento do franqueado com } \\
\text { os outros fornecedores de insumos. }\end{array}$ & Prova Qui-Quadrado & 0,603 \\
\hline $\begin{array}{l}\text { Considerado na avaliação: Participação da loja em ações sociais } \\
\text { promovidas pela rede }\end{array}$ & Prova Qui-Quadrado & 0,824 \\
\hline $\begin{array}{l}\text { O franqueador verifica se as metas/objetivos foram alcançados } \\
\text { para as lojas próprias }\end{array}$ & Prova de Fisher & 0,619 \\
\hline $\begin{array}{l}\text { As avaliações e seus procedimentos geram conflitos com (ou } \\
\text { entre) os franqueados? }\end{array}$ & Prova de Fisher & 0,669 \\
\hline
\end{tabular}

Tabela 35 - Comparação entre Royalty $X$ remuneração por Taxa fixa

\begin{tabular}{lc}
\hline Índice & $\chi^{2}$ \\
aval_aspecto_vendas & 3,457 \\
aval_aspecto_financeiro & 1,087 \\
aval_aspecto_operação_manutenção & 3,889 \\
aval_aspecto_imagem_marca & 1,270 \\
aval_aspecto_marketing & 0,972 \\
aval_aspecto_equipe & 2,579 \\
aval_aspecto_logistica & 1,829 \\
aval_aspecto_parceiros & 2,763 \\
aval_aspecto_inovação & 4,464 \\
\hline & \\
\hline valor critico $\chi^{2}=4,60$ & \\
\hline
\end{tabular}




\subsection{Anexo II - Provas estatísticas: Definição de objetivos e acompanhamento}

Apresentam-se as variáveis em que não foi possível concluir pela dependência com a variável de definição de objetivos e acompanhamento nas tabelas a seguir.

Tabela 36 - Provas estatísticas para Define e objetivos

\section{Questão}

Prova Estatístical

O franqueador realiza avaliação das LOJAS FRANQUEADAS?

Etapas presentes na avaliação Punição em função do resultado medido.

O franqueador realiza avaliação das LOJAS PRÓPRIAS?

(p)

Considerado na avaliação: Volume de produtos vendidos pela loja.

Considerado na avaliação: Volume de produtos vendidos para o

franqueado.

Considerado na avaliação: Faturamento da loja.

Prova de Fisher

0,413

Considerado na avaliação: Retorno sobre ativos na loja.

Prova Qui-quadrado

0,135

Prova de Fisher

0,707

Prova Qui-quadrado

0,185

Considerado na avaliação: Custos operacionais da loja.

Prova Qui-quadrado

0,778

Prova de Fisher

0,241

Prova de Fisher

Considerado na avaliação: Despesas com impostos da loja.

Prova Qui-quadrado

0,223

Considerado na avaliação: Despesas financeiras da loja.

Prova Qui-quadrado

0,422

Considerado na avaliação: Respeito aos padrões da marca.

Prova Qui-quadrado

0,750

Prova de Fisher

0,148

Considerado na avaliação: Outros aspectos de infra-estrutura

Prova Qui-quadrado

0,185

Considerado na avaliação: Satisfação do cliente daquela loja.

Prova Qui-quadrado

0,187

Considerado na avaliação: Mudanças relevantes na região

Prova Qui-quadrado

Prova de Fisher

0,311

Considerado na avaliação: Satisfação / Motivação da equipe

Prova Qui-quadrado

0,166

Considerado na avaliação: Rotatividade dos funcionários

Prova de Fisher

0,432

Considerado na avaliação: Uso dos softwares de gestão

Prova Qui-quadrado

0,166

Considerado na avaliação: Preenchimento dos pedidos

Prova Qui-quadrado

0,625

Considerado na avaliação: Estoque (variabilidade de tamanhos, tipos, moda)

Prova Qui-quadrado

Considerado na avaliação: Perdas de estoque

Considerado na avaliação: Tempo de entrega dos produtos / insumos na loja

Prova Qui-quadrado

0,847

Considerado na avaliação: Recebimento dos produtos/ insumos na loja Prova Qui-quadrado

Considerado na avaliação: Relacionamento do franqueado com os outros fornecedores de insumos.

Prova Qui-quadrado

Considerado na avaliação: Participação da loja em ações sociais promovidas pela rede

Prova Qui-quadrado

Considerado na avaliação: Processos Judiciais de terceiros contra a loja/franqueado

Prova Qui-quadrado 
Tabela 37 - Provas estatísticas Mann Whitney

\begin{tabular}{lccc}
\hline & Mann-Whitney U & $\mathbf{Z}$ & $\begin{array}{c}\text { p (nível } \\
\text { descritivo) }\end{array}$ \\
\hline 3. Dessas, quantas são lojas franqueadas? & 383,500 & $-1,362$ & 0,173 \\
7. Qual o investimento total abrir uma loja padrão? & 371,500 & $-1,531$ & 0,126 \\
8. Em quanto tempo, em média, o franqueado padrão & 411,000 & $-0,993$ & 0,321 \\
recupera o investimento? (em meses) & 455,500 & $-0,357$ & 0,721 \\
tempo de franquia &
\end{tabular}

Tabela 38 - Mann-Whitney Frequiências

\begin{tabular}{lllcc}
\hline & estrut_def & N & $\begin{array}{c}\text { Média de } \\
\text { postos }\end{array}$ & $\begin{array}{c}\text { Soma de } \\
\text { postos }\end{array}$ \\
\hline 2. Quantas lojas operam com a sua marca? & sem estrutura & 26 & 27,02 & 702,50 \\
& estruturada & 37 & 35,50 & $1.313,50$ \\
& Total & 63 & & \\
3. Dessas, quantas são lojas franqueadas? & sem estrutura & 26 & 28,25 & 734,50 \\
& estruturada & 37 & 34,64 & $1.281,50$ \\
& Total & 63 & & \\
7. Qual o investimento total necessário para & sem estrutura & 26 & 27,79 & 722,50 \\
abrir uma loja padrão? & estruturada & 37 & 34,96 & $1.293,50$ \\
& Total & 63 & & \\
8. Em quanto tempo, em média, o & sem estrutura & 26 & 34,69 & 902,00 \\
franqueado padrão recupera o investimento? & estruturada & 37 & 30,11 & $1.114,00$ \\
(em meses) & Total & 63 & & \\
Tempo de franquia & sem estrutura & 26 & 31,02 & 806,50 \\
& estruturada & 37 & 32,69 & $1.209,50$ \\
& Total & 63 & & \\
\hline
\end{tabular}

Tabela 39 - Kolmogorov-Smirnov para Define objetivos

\begin{tabular}{|c|c|c|c|c|}
\hline \multirow[b]{2}{*}{ Questão } & \multicolumn{3}{|c|}{ Maior diferença } & \multirow{2}{*}{$\begin{array}{c}\text { Kolmogorov- } \\
\text { Smirnov (Qui- } \\
\text { Quadrado) }\end{array}$} \\
\hline & Absoluta & Positiva & Negativa & \\
\hline $\begin{array}{l}\text { 31. O franqueador avalia as lojas } \\
\text { franqueadas de quanto em quanto tempo? }\end{array}$ & 0,106 & 0,031 & $-0,106$ & 0,634 \\
\hline $\begin{array}{l}\text { 33. Número de indicadores construídos para } \\
\text { a rede de franquias }\end{array}$ & 0,155 & 0,000 & $-0,155$ & 1,140 \\
\hline $\begin{array}{l}\text { 34. Número de indicadores construídos para } \\
\text { a loja franqueada }\end{array}$ & 0,243 & 0,000 & $-0,243$ & 2,722 \\
\hline
\end{tabular}

\begin{tabular}{|lcc|}
\hline & Maior diferença & Kolmogorov-Smirnov \\
índices & Absoluta & (Qui-Quadrado) \\
aval_franq_relacionamento & 0,204 & 2,535 \\
\hline
\end{tabular}




\subsection{Anexo III - Provas estatísticas: Tamanho da rede}

Apresentam-se alguma das variáveis em que não foi possível concluir pela dependência com a variável de tamanho da rede. Não foram expostas as provas estatísticas relativas às variáveis binárias, com resultados sem significância.

Tabela 40 - Prova estatística para Tamanho da rede.

\begin{tabular}{l|c|c|c|c}
\hline & \multicolumn{3}{|c|}{ Maior diferença } & Kolmogorov-Smirnov \\
Questão & Absoluta & Positiva & Negativa & Qui-Quadrado) \\
\hline $\begin{array}{l}\text { O franqueador avalia as lojas franqueadas } \\
\text { de quanto em quanto tempo? }\end{array}$ & 0,076 & 0,076 & $-0,017$ & 0,339 \\
$\begin{array}{l}\text { 33. Número de indicadores construídos } \\
\text { para a rede de franquias }\end{array}$ & 0,068 & 0,000 & $-0,068$ & 0,236 \\
$\begin{array}{l}\text { 34. Número de indicadores construídos } \\
\text { para a loja franqueada }\end{array}$ & 0,104 & 0,019 & $-0,104$ & 0,532 \\
\hline
\end{tabular}

Tabela 41 - Comparação entre grandes e pequenas franquias

\begin{tabular}{lc}
\hline índice & $\chi^{2}$ \\
aval_aspecto_vendas & 0,223 \\
aval_aspecto_financeiro & 1,166 \\
aval_aspecto_operação_manutenção & 3,905 \\
aval_aspecto_marketing & 2,051 \\
aval_aspecto_equipe & 0,968 \\
aval_aspecto_logistica & 2,191 \\
aval_aspecto_inovação & 0,861 \\
& \\
valor critico $\chi^{2}=4,60$ & \\
\hline
\end{tabular}

